
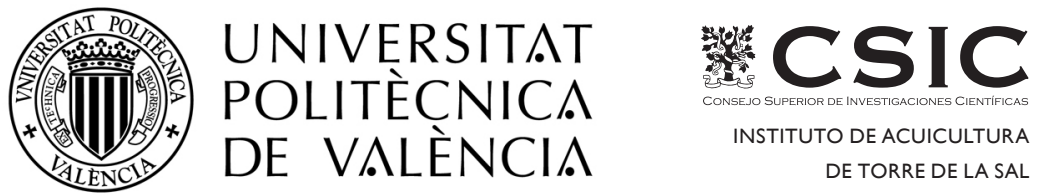

\title{
CARACTERIZACIÓN BIOLÓGICA DE LAS GONADOTROFINAS DE LUBINA \\ (Dicentrarchus labrax) Y DESARROLLO \\ DE HERRAMIENTAS BIOTECNOLÓGICAS E \\ INMUNOLÓGICAS PARA SU ESTUDIO
}

Memoria presentada por Gregorio Molés Miró para optar al grado de Doctor.

Fdo.

Gregorio Molés Miró

Tesis Doctoral dirigida por la Dra. Silvia Zanuy Doste.

UNIVERSIDAD POLITÉCNICA DE VALENCIA

Departamento de Ciencia Animal

Valencia, Octubre 2011 
Diseño de cubierta

Julio Dolbeth 
La Dra. Silvia Zanuy Doste, Profesora de Investigación del CSIC en el Departamento de Fisiología de Peces y Biotecnología del Instituto de Acuicultura Torre la Sal, hace constar que:

Gregorio Molés Miró, licenciado en Ciencias Biológicas, ha realizado bajo su dirección en el Instituto de Acuicultura de Torre la Sal (CSIC) el trabajo de investigación recogido en esta memoria que lleva por título: "Caracterización biológica de las gonadotrofinas de Lubina (Dicentrarchus labrax) y desarrollo de herramientas biotecnológicas e inmunológicas para su estudio", para optar al grado de doctor por la Universidad Politécnica de Valencia.

Torre de la Sal,

Fdo.

Dra. Silvia Zanuy Doste 

Caracterización biológica de las gonadotrofinas de lubina (Dicentrarchus labrax) y desarrollo de herramientas biotecnológicas e inmunológicas para su estudio 



\section{Indice}

Agradecimientos

Abreviaturas y acrónimos $\quad 11$

Capítulo 1. INTRODUCCIÓN GENERAL — $\quad 21$

Introducción —_a 23

La lubina europea $\quad 24$

La reproducción en teleósteos $\quad 24$

Gametogénesis en machos $\quad 25$

Gametogénesis en hembras — 27

Control endocrino de la reproducción en teleósteos $\quad 31$

Cerebro $\quad 32$

Hipófisis — 36

Gónadas $\quad 50$

Métodos de cuantificación de gonadotrofinas $\quad 53$

Inmunoensayos $\quad 53$

Bioensayos $\quad 55$

Capítulo 2. OBJETIVOS $\quad 59$

Capítulo 3. Temporal profile of brain and pituitary GnRHs, GnRH-R and gonadotropin mRNA expression and content during early development in European sea bass (Dicentrarchus labrax).

Capítulo 4. Purification and characterization of follicle-stimulating hormone from pituitary glands of sea bass (Dicentrarchus labrax). 93

Capítulo 5. Receptor Specificity and Functional Comparison of Recombinant Sea Bass (Dicentrarchus labrax) Gonadotropins (Fsh and Lh) Produced in Different Host Systems

Capítulo 6. Determination of Fsh Quantity and Bioactivity During Sex Differentiation and Oogenesis in European Sea Bass 
Capítulo 7. Development of homologous enzyme-linked immunosorbent assay for European sea bass FSH. Reproductive cycle plasma levels in both sexes and in yearling precocious and non-precocious males

Capítulo 8. DISCUSIÓN GENERAL 213

Capítulo 9. CONCLUSIONES 235

Bibliografía general 241

Resumenes 259 


\section{Abreviaturas y Acrónimos}

11-KT 11-ketotestosterona

$3 \beta$-HDS $3 \beta$-hidroxiesteroide deshidrogenasa/ $\Delta 5-\Delta 4$-isomerasa

$11 \beta$-HDS $11 \beta$-hidroxiesteroide deshidrogenasa

17,20 $\beta \mathrm{P} \quad 17 \alpha, 20 \beta$-dihidroxi-4-pregnen-3-ona

17 $\beta$-HDS 17 $\beta$-hidroxiesteroide deshidrogenasa

$20 \beta S \quad 17 \alpha, 20 \beta, 21$-trihidroxi-4-pregnen-3-ona

ADN ácido desoxirribonucleico

ADNc ADN complementario

Ac anticuerpo

Ag antígeno

AG aparato de Golgi

AMPc monofosfato de adenosina cíclico

ARN ácido ribonucleico

$\operatorname{Arg}(\mathrm{R}) \quad$ arginina

ASi ácido siálico

Asn (N) asparragina

Asp (D) ácido aspártico

ATP trifosfato de adenosina

ARNm ácido ribonucleico mensajero

$\alpha \mathrm{L} \quad$ lazo horquilla $\beta$ subunidad- $\alpha$

B:I relación entre bioactividad e inmunoactividad

$\beta \mathrm{L} \quad$ lazo horquilla $\beta$ subunidad- $\beta$

CG gonadotropina corionica placentaria

CGPs células germinales primordiales

$\mathrm{CHO} \quad$ ovario de hámster chino

CHG cerebro-hipófisis-gónada

CRE elemento de respuesta a AMPc

CSIC Consejo Superior de Investigaciones Científicas

CTP péptido carboxi-terminal

Cys (C) cisteína

CV coeficiente de variación 
dph días post-eclosión

E2 17ß-estradiol

ELISA ensayo por inmunoabsorción ligado a enzimas

FSH hormona estimulante del folículo

FSHR receptor de FSH

FSH $\beta \quad$ subunidad FSH $\beta$

Fuc fucosa

GABA ácido gamma-amino butírico

Gal galactosa

GFRP Grupo Fisiología de la Reproducción de Peces

Gln (Q) glutamina

Glu (E) ácido glutámico

Gly (G) glycina

GnRH hormona liberadora de gonadotrofinas

GnRHR receptor de $\mathrm{GnRH}$

GP $\alpha \quad$ subunidad $\alpha$ de FSH, LH o TSH (también Cga)

GpHRs receptores de hormonas glicoproteicas

GPCR receptor acoplado a proteína $\mathrm{G}$

GTH I gonadotrofina I o FSH

GTH II gonadotrofina II o LH

GTHRs receptores de gonadotrofinas (FSHR y LHR)

GV Generalitat Valenciana

HEK riñón embrionario humano

His $(\mathrm{H}) \quad$ histidina

IATS Instituto de Acuicultura de Torre de la Sal

IP3 inositol trifosfato

I3P beca predoctoral de investigación con interés para el sector industrial

kDa kilodalton

Leu (L) leucina 


$\begin{array}{ll}\text { LH } & \text { hormona luteinizante } \\ \text { LHR } & \text { receptor de LH } \\ \text { LH } \beta & \text { subunidad LH } \beta \\ \text { LRR } & \begin{array}{l}\text { repeticiones ricas en leucina } \\ \text { Lys (K) }\end{array} \\ \text { lisina } \\ \text { Man } & \text { manosa } \\ \text { MAPK } & \text { proteína quinasa activada por mitógeno } \\ \text { MEC } & \text { Ministerio de Educación y Ciencia } \\ \text { Met (M) } & \text { metionina } \\ \text { MIS } & \text { esteroides inductores de la maduración } \\ & \\ \text { NAG } & \text { N-acetilglucosamina } \\ \text { NPY } & \text { neuropeptido Y }\end{array}$

P45011 P450 11 $\beta$-hidroxilasa

P450arom citocromo P450 aromatasa, gonadal (CYP19A1) y cerebral (CYP19A2)

P450c17 citocromo P450 17 $\alpha$-hidroxilasa/17,20-liasa (CYP17)

P450scc citocromo P450 de escisión de la cadena lateral de colesterol (CYP11A)

PAGE electroforesis en gel de poliacrilamida

PCR reacción en cadena de la polimerasa

Phe (F) fenilalanina

PDP pars distalis proximal

PDR pars distalis rostral

PI pars intermedia

PKA proteína quinasa $\mathrm{A}$

PKB proteína quinasa $B$

PNGase F péptido $N$-glicosidasa $F$

Pro (P) prolina

Proteína G proteína heterotrimerica que se une a nucleótidos de guanina

RIA radioinmunoensayo

RER retículo endoplasmático rugoso

scGTHs GTHs de cadena única 
SDS dodecilsulfato sódico

Ser $(\mathrm{S}) \quad$ serina

Sf Spodoptera frugiperda

SGK proteína quinasa inducida por suero y glucocorticoides

StAR proteína reguladora de la respuesta esteroidogénica aguda

$\mathrm{T} \quad$ testosterona

TSH hormona estimulante del tiroides o tirotrofina

TSHR receptor de TSH

Tyr (Y) tirosina

UAB Universitat Autònoma de Barcelona

UB Universitat de Barcelona

Val (V) valina

VG vesícula germinal

VTG vitelogenina

\section{Abbreviations and Acronyms}

2-ME 2-mercaptoethanol

11-KT 11-ketotestosterone

$\begin{array}{ll}\text { Ala (A) } & \text { alanine } \\ \text { ANOVA } & \text { analysis of variance } \\ \text { Arg (R) } & \text { arginine } \\ \text { Asn (N) } & \text { asparagine } \\ \text { Asp (D) } & \text { aspartic acid } \\ \text { ATP } & \text { adenosine triphosphate } \\ \text { atre } & \text { atresia } \\ \text { AU } & \text { absorbance unit } \\ \text { AUC } & \text { area under the concentration-time curve } \\ & \\ \text { B0 } & \text { maximun binding } \\ \text { Bi } & \text { sample binding } \\ \text { B:I } & \text { biological to immunological ratio } \\ \text { BLAST } & \text { basic local alignment search tool }\end{array}$




$\begin{array}{ll}\text { BMGY } & \text { buffered glycerol-complex medium } \\ \text { BMMY } & \text { buffered methanol-complex medium } \\ \text { bp } & \text { base pair } \\ \text { BSA } & \text { bovine serum albumin }\end{array}$

$\begin{array}{ll}\text { cAMP } & \text { adenosine 3',5'-cyclic-monophosphate } \\ \text { cDNA } & \begin{array}{l}\text { complementary deoxyribonucleic acid } \\ \text { chorionic gonadotropin } \\ \text { CG }\end{array} \\ \text { CHO } & \begin{array}{l}\text { chinese hamster ovary } \\ \text { clearance rate }\end{array} \\ \text { CoA } & \text { coenzyme A } \\ \text { Con A } & \text { concanavalin A } \\ \text { CRE } & \text { cAMP response element } \\ \text { CTP } & \text { carboxy-terminal peptide } \\ \text { Cys }(C) & \text { cysteine } \\ \text { CV } & \text { coefficients of variation }\end{array}$

DMEM dulbecco modified eagle's medium

DNA deoxyribonucleic acid

DNase deoxyribonuclease

dNTP deoxyribonucleoside triphosphate

dph days post-hatching

DTT dithiothreitol

E2 $17 \beta$-estradiol

E-AChE estradiol acetylcholinesterase conjugate

EC50 half maximal effective concentration

E. coli Escherichia coli

EDTA ethylendiamin-tetra-acetate

EEC European Economic Community

e.g. exempligratia (for example)

EIA enzyme immunoassay

ELISA enzyme-linked immunosorbent assay

EU European Union

E.U. Ellman Units

evtg early vitellogenesis 
FBS foetal bovine serum

FSH follicle-stimulating hormone

FSHR FSH receptor

FSH $\beta \quad$ FSH $\beta$-subunit

g relative centrifugal force

g gram

G418 aminoglycoside antibiotic

GAR Goat anti-rabit antibodies

$G$ protein heterotrimeric guanine nucleotide-binding protein

Gln (Q) glutamine

Glu (E) glutamic acid

Gly (G) glycine

GnRH gonadotropin-releasing hormone

GnRHR GnRH receptor

GP $\alpha$ glycoprotein $\alpha$-subunit (also Cga)

GSI gonadosomatic index

GTH I gonadotropin I

GTH II gonadotropin II

h hour

HEK human embryonic kidney

His $(\mathrm{H}) \quad$ histidine

HPLC high-performance liquid chromatography

HRP horseradish peroxidase

i.e. id est (that is)

IgG immunoglobulin G

Ile (I) isoleucine

IMAC immobilized metal affinity chromatography

IU international unit

kV kilovolts

kDa kilodalton

L liter

LL continuos light 


$\begin{array}{ll}\text { Leu }(\mathrm{L}) & \text { leucine } \\ \text { LH } & \text { luteinizing hormone } \\ \text { LHR } & \text { LH receptor } \\ \text { LH } \beta & \text { LH } \beta \text {-subunit } \\ \text { LUC } & \text { Luciferase } \\ \text { lvtg } & \text { late vitellogenesis } \\ \text { Lys (K) } & \text { lysine } \\ & \\ \text { M } & \text { molecular weight marker } \\ \text { mAb } & \text { monoclonal antibodies } \\ \text { MALDI } & \text { matrix-assisted laser desorption/ionization } \\ \text { mat } & \text { maturation } \\ \text { MD } & \text { minimal dextrose medium } \\ \text { Met (M) } & \text { methionine } \\ \text { mg } & \text { milligram } \\ \text { min } & \text { minute } \\ \text { ml } & \text { milliliter } \\ \text { mm } & \text { millimeter } \\ \text { mM } & \text { millimolar } \\ \text { MOI } & \text { multiplicity of infection } \\ \mathrm{mRNA} & \text { messenger RNA } \\ \mu \mathrm{g} & \text { microgram } \\ \mu \mathrm{l} & \text { microliter } \\ \mu \mathrm{M} & \text { micromolar } \\ \mu \mathrm{m} & \text { micrometer } \\ \mathrm{N} & \text { normality } \\ \mathrm{n} & \text { number of observations } \\ \mathrm{ng} & \text { nanogram } \\ \mathrm{NGS} & \text { normal goat serum } \\ \mathrm{nm} & \text { nanometer } \\ \mathrm{NP} & \text { natural photoperiod } \\ \mathrm{NSB} & \text { non-specific binding } \\ \mathrm{ORF} & \text { open reading frame } \\ \text { ovul } & \text { ovulation } \\ \mathrm{P} & \text { probality value } \\ & \end{array}$




$\begin{array}{ll}\text { P450arom } & \text { cytochrome P450 aromatase (CYP19) } \\ \text { PAGE } & \text { polyacrylamide gel electrophoresis } \\ \text { PBS } & \text { phosphate buffered saline } \\ \text { PBST } & \text { phosphate buffered saline-Tween 20 } \\ \text { PCR } & \text { polymerase chain reaction } \\ \text { pfu } & \text { plaque-forming unit } \\ \text { pg } & \text { picogram } \\ \text { pH } & \text { negative log of hydrogen ion concentration } \\ \text { Phe (F) } & \text { phenylalanine } \\ \text { PI } & \text { pars intermedia } \\ \text { Pit } & \text { pituitary } \\ \text { PMSF } & \text { phenylmethylsulfonyl fluoride } \\ \text { PNGase F } & \text { peptide- } N \text {-glycosidase F } \\ \text { POA } & \text { preoptic area } \\ \text { PPD } & \text { proximal pars distalis } \\ \text { prevtg } & \text { previtellogenesis } \\ \text { Pro (P) } & \text { proline } \\ \text { PVDF } & \text { Polyvinylidene difluoride } \\ \text { pvtg } & \text { postvitellogenesis } \\ & \\ \text { R } & \text { correlation coefficient } \\ \text { RIA } & \text { radioimmunoassays } \\ \text { RLU } & \text { relative light units } \\ \text { RNA } & \text { ribonucleic acid } \\ \text { rp } & \text { reversed-phase } \\ \text { rpm } & \text { revolutions per minute } \\ & \\ \text { s } & \text { second } \\ \text { sbs } & \text { sea bass } \\ \text { scGTHs } & \text { single chain gonadotropins } \\ \text { Sf } & \text { Spodoptera frugiperda } \\ \text { SBR } & \text { Sea Bass Ringer } \\ \text { SD } & \text { standard deviation } \\ \text { SDP } & \text { sex differentiation period } \\ \text { SDS } & \text { sodium dodecyl sulphate } \\ \text { SEM } & \text { standard error of the mean } \\ \text { Ser (S) } & \text { serine } \\ & \end{array}$




$\begin{array}{ll}\text { T } & \text { testosterone } \\ \text { TBS-T } & \text { Tris-Buffered Saline-Tween } 20 \\ \text { TFA } & \text { trifluoroacetic acid } \\ \text { TMB } & \text { tetramethylbenzidine } \\ \text { TOF } & \text { time-of-flight mass spectrometer } \\ \text { Tris } & \text { tris-(hydroxymethyl)-aminomethane } \\ \text { TSH } & \text { thyroid-stimulating hormone } \\ \text { Tyr (Y) } & \text { tyrosine } \\ \text { U } & \text { units } \\ \text { UV } & \text { ultraviolet } \\ \text { v } & \\ \text { Val (V) } & \text { volume } \\ \text { wt } & \text { weight } \\ \text { YPD } & \text { yeast extract peptone dextrose medium }\end{array}$



Capítulo 1. INTRODUCCIÓN GENERAL 



\section{Introducción}

Los peces teleósteos representan el grupo más grande y diverso de vertebrados (más de 29.000 especies). Se caracterizan principalmente por tener esqueleto óseo y habitar una gran diversidad de biotopos. Para asegurar el éxito reproductivo han desarrollado adaptaciones al medio, generando gran diversidad de estrategias reproductivas con diferentes grados de especialización que van desde la fertilización externa (la mayoría de teleósteos) a la interna. Los peces teleósteos son predominantemente gonocoristas aunque es frecuente encontrar especies hermafroditas, sobre todo en el orden Perciformes. En general, estas diferencias provocan que el inicio de la pubertad, los ritmos de gametogénesis y la propia reproducción sean extremadamente variables entre especies (Vizziano et al., 2008).

La reproducción es un proceso estacional que tiene lugar como consecuencia de la integración de la información ambiental, captada por los sistemas sensoriales, y su transducción en una cascada hormonal que desencadena la producción de gametos en el momento más favorable para la supervivencia de la progenie en un determinado ecosistema. Desde un punto de vista práctico, el control de la reproducción de un organismo es importante y limitante para su producción en cautividad. En ocasiones, la reproducción es un proceso aleatorio y poco controlado, en parte, como consecuencia de alteraciones de las condiciones ambientales en las que se mantienen los animales en cultivo. Estas alteraciones afectan a la evolución normal del proceso reproductivo porque perturban el sistema endocrino a distintos niveles. Así, para poder controlar eficazmente la reproducción de un organismo es necesario conocer profundamente los procesos básicos que regulan la alternancia de su ciclo reproductor y su puesta en funcionamiento. Por lo tanto, dilucidar los eventos endocrinos y neuroendocrinos que regulan la reproducción es crucial para el desarrollo de la acuicultura. 


\section{La lubina europea}

La lubina, Dicentrarchus labrax, es un teleósteo marino de gran interés económico en acuicultura. Pertenece al orden Perciformes y a la familia Moronidae. Se distribuye principalmente por el mar Mediterráneo y las costas del océano Atlántico, desde el norte de Noruega hasta Marruecos. Vive en un amplio rango de ambientes gracias a su capacidad eurihalina (3-38\%) y euriterma $\left(2-32^{\circ} \mathrm{C}\right)$ (Carrillo et al., 1995; Pickett y Pawson, 1994).

La lubina es una especie gonocorista, con sexos separados, pero carece de caracteres sexuales externos para identificarlos. No obstante, normalmente, las hembras alcanzan mayor tamaño que los machos. Se reproduce en invierno (Diciembre-Marzo) y la mayoría de los machos alcanzan la primera maduración sexual al segundo año de vida mientras que las hembras maduran un año después. A igual edad, el retraso de la maduración sexual en las hembras favorece un mayor crecimiento corporal ya que los machos tienen que destinar parte de la energía consumida en el desarrollo de las gónadas. Las hembras de lubina presentan un desarrollo ovárico de tipo síncrono por grupos, de manera que producen 3-4 puestas consecutivas durante el periodo de puesta (1-2 meses) (Carrillo et al., 1995). Los huevos son pelágicos y transparentes, con 1 o 2 gotas de grasa. El desarrollo embrionario dura unos 4 días a $15^{\circ} \mathrm{C}$ y el desarrollo larvario unos 40 días a $19^{\circ} \mathrm{C}$. Los juveniles habitan en aguas costeras y estuarios donde crecen y progresan hacia la pubertad (Barnabé, 1991; Carrillo et al., 1995; Pickett y Pawson, 1994).

\section{La reproducción en teleósteos}

La reproducción sexual es uno de los procesos biológicos más relevantes que ocurren en la Naturaleza. Se basa en la creación de un nuevo organismo a partir de la fusión de dos gametos de sexo opuesto. Este proceso permite la recombinación del ADN parental, aumentando la diversidad genética de la descendencia. La producción de gametos o gametogénesis tiene lugar en las gónadas mediante un proceso de meiosis. En general, en peces, el ciclo reproductor se divide en dos fases, una fase inicial de crecimiento y desarrollo gonadal, y una segunda fase de maduración de los gametos. 


\section{Gametogénesis en machos}

\section{Morfología del testículo}

En la mayoría de los casos, los testículos de teleósteos son dos órganos alargados separados por un septo y unidos a la pared dorsal de la cavidad corporal. De la superficie medio dorsal posterior de cada testículo sale el espermiducto que desemboca en la papila urogenital (Nagahama, 1983). Internamente, en los testículos se distingue un compartimento germinal y otro intersticial, ambos separados por una membrana basal. El compartimento germinal está compuesto por células germinales y células somáticas asociadas o células de Sertoli, mientras que el compartimento intersticial, lo constituyen células especializadas o células de Leydig, tejido conectivo, vasos sanguíneos y vasos linfáticos (Fig. 1). En los teleósteos se han descrito dos tipos de estructura testicular, la tubular y la lobular, en función de la morfología del compartimento germinal y de la distribución de las células germinales en su interior (Grier, 1993). El tipo tubular está formado por un

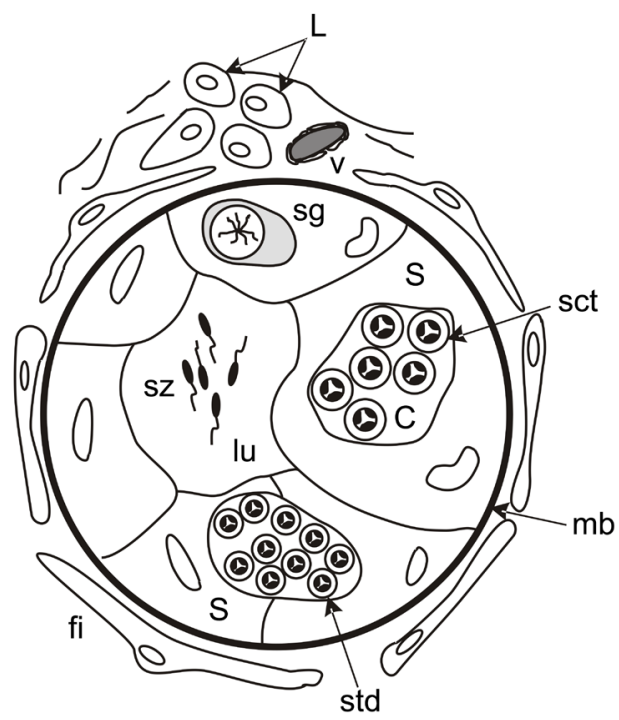

Figura 1. Representación esquemática de un lóbulo testicular durante la espermatogénesis (sección transversal). Las células de Leydig (L) y los vasos sanguíneos (v) se localizan en el compartimento intersticial, entre lóbulos adyacentes. En el compartimento germinal, las células de Sertoli (S) nutren a las células germinales en desarrollo durante las diferentes fases de la espermatogénesis. Espermatogonias (sg), espermatocitos (sct), espermátidas (std), espermatozoides (sz), cistes o espermatocistes (C), lumen lobular (lu), membrana basal (mb), fibroblastos (fi). Adaptado de Billard et al. (1982). 
conjunto de túbulos que se extienden desde la periferia del testículo hasta el centro del mismo donde convergen en un gran conducto. Esta estructura es típica de especies con fecundación interna. El testículo de tipo lobular es el más común entre los teleósteos Perciformes y está compuesto por numerosos lóbulos ramificados y anastomosados entre si. En cada uno de estos lóbulos, las células de Sertoli engloban clones de células germinales en el mismo estado de desarrollo (Billard et al., 1982; Pudney, 1995) formando las unidades funcionales del testículo donde tiene lugar la espermatogénesis, los espermatocistes. El espermatociste más simple lo constituye una sola célula germinal o espermatogonia rodeada por una o dos células de Sertoli que se encargan de suministrar el entorno necesario para su supervivencia, proliferación y diferenciación. Durante la espermatogénesis, la célula germinal sufre una serie de divisiones mitóticas y meióticas hasta dar lugar a los espermatozoides. En el compartimiento intersticial, situado entre los lóbulos testiculares, se encuentran las células de Leydig que producen los esteroides necesarios para que tenga lugar la gametogénesis (Nagahama, 1994).

\section{Espermatogénesis}

La espermatogénesis es un proceso altamente organizado y coordinado en el cual células madre espermatogoniales (diploides) proliferan y se diferencian para dar lugar a espermatozoides maduros (haploides). Durante este proceso pueden distinguirse cinco fases principales (Fig. 2): 1) renovación de espermatogonias, 2) proliferación espermatogonial "hacia la meiosis", 3) meiosis, 4) espermiogénesis y 5) maduración del esperma (Zanuy et al., 2009).

Tras la diferenciación de células germinales primordiales (CGPs) en células madre espermatogoniales o espermatogonias A, se produce una renovación por mitosis dando lugar a espermatogonias similares. Posteriormente, durante la proliferación espermatogonial, las mitosis ya no dan lugar a espermatogonias A y cada generación de espermatogonias se distingue de la anterior por un conjunto de características morfológicas, como el incremento de la heterocromatina y la disminución del tamaño celular (Zanuy et al., 2009). La última generación de espermatogonias, denominadas espermatogonias B, entra en mitosis para dar lugar a los espermatocitos primarios. Estos experimentan la primera división meiótica, dando lugar a los espermatocitos secundarios de vida media muy corta, que después de la segunda división meiótica se convierten en espermátidas. Posteriormente, tras una 


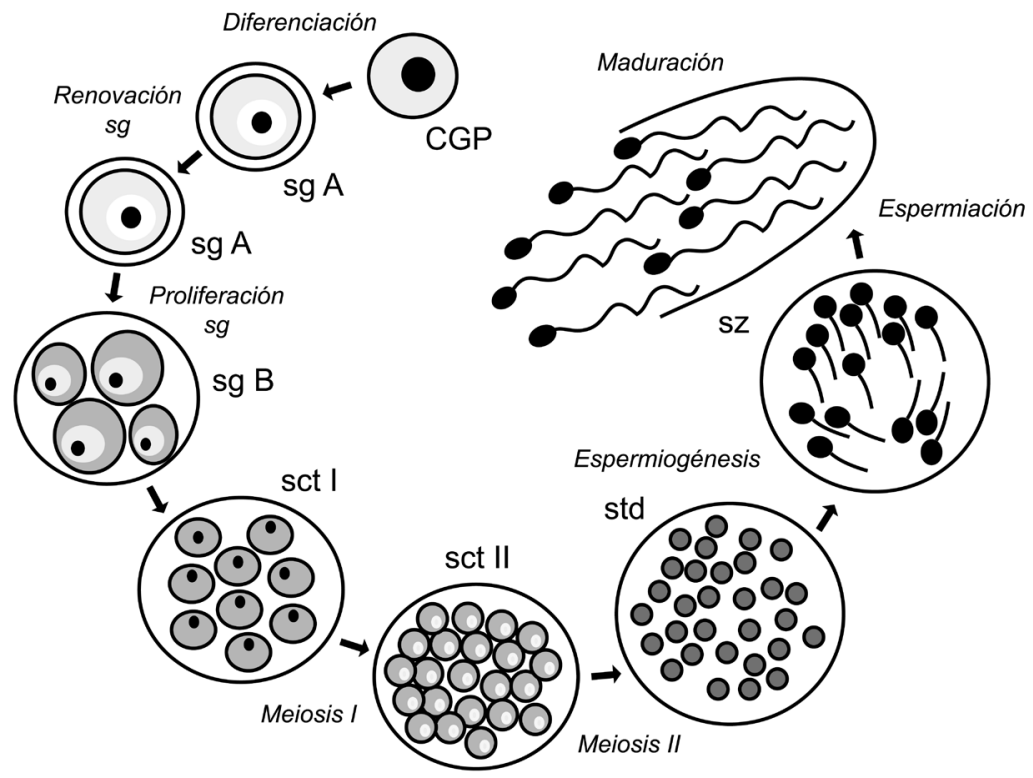

Figura 2. Representación esquemática del proceso de espermatogénesis en teleósteos. Célula germinal primordial (CGP), espermatogonia A (sg A), espermatogonia B (sg B), espermatocitos I y II (sct I y II), espermátidas (std), espermatozoides (sz).

serie de cambios morfológicos las espermátidas sufren una reducción del volumen nuclear y celular, convirtiéndose en espermatozoides (espermiogénesis) (Schulz et al., 2010; Zanuy et al., 2009). Por último, los espermatocistes se abren mediante ruptura de las células de Sertoli y los espermatozoides son liberados (espermiación) a la luz lobular y de allí al espermiducto, donde adquieren motilidad (maduración) y capacidad de fertilización (Schulz et al., 2010).

\section{Gametogénesis en hembras}

\section{Morfología del ovario}

El ovario de los teleósteos, a diferencia del de los mamíferos, muestra diferencias inter-específicas, reflejando un amplio rango de patrones o estrategias reproductivas. Sin embargo, las estructuras fundamentales, como la morfología de las células germinales y los elementos somáticos que constituyen el tejido gonadal, son similares (Nagahama, 1983). En general, los ovarios son órganos pares, alargados y situados dorsalmente en la cavidad 
abdominal (Jalabert, 2005). Internamente, el ovario está formado por un tejido de soporte o estroma ovárico compuesto por fibras de colágeno, envuelto por una capa muscular lisa, tejido vascular y tejido nervioso. En la zona central está la cavidad ovárica, hacia la que se proyectan multitud de pliegues del estroma formando las láminas o lamelas ováricas, en las que se asienta el epitelio germinativo ovárico, formado por células germinales y epiteliales somáticas (Grier y Lo Nostro, 2000). La parte posterior de cada ovario se conecta mediante un oviducto con la papila o poro genital por el que se liberan los oocitos (Jalabert, 2005). Cada oocito está delimitado por una envoltura denominada corion o zona radiata que a su vez está rodeada de una capa de células somáticas epiteliales especializadas o células de la granulosa. Estas células secretan una membrana basal y alrededor de ella se organiza otra fina monocapa de células somáticas llamadas células de la teca, fibroblastos y vasos sanguíneos (Fig. 3). El oocito y sus correspondientes envolturas foliculares (células de la granulosa y de la teca) forman el folículo y constituye la unidad ovárica básica (Yaron y Levavi-Sivan, 2006; Zanuy et al., 2009).

Atendiendo al ritmo de desarrollo de los oocitos se han definido tres tipos principales de ovarios (Wallace y Selman, 1981):

a) Ovarios con desarrollo síncrono. En este tipo de ovario todos los oocitos se desarrollan y ovulan al mismo tiempo. Es propio de especies que po-

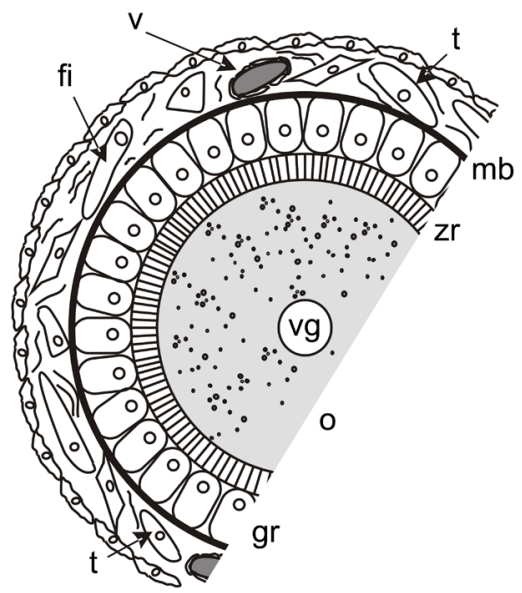

Figura 3. Representación esquemática de un folículo ovárico en vitelogénesis temprana. Vasos sanguíneos (v), fibroblastos (fi), células de la teca ( $\mathrm{t}$ ), membrana basal (mb), células de la granulosa (gr), zona radiata (zr), oocito (o), vesícula germinal o núcleo (vg), Adaptado de Nagahama (1983). 
nen un vez en la vida y después mueren, como los salmones del Pacífico (Oncorhynchus spp.).

b) Ovarios con desarrollo síncrono por grupos. En este caso el ovario posee al menos dos grupos de oocitos en distinto estado de desarrollo. Es propio de especies de puesta estacional y se pueden dividir en dos subgrupos, especies de puesta única o puesta múltiple. En especies de puesta única el grupo de oocitos más avanzado se desarrolla de forma simultanea, produciendo una sola puesta al año como la trucha arcoiris (Oncorhynchus mikiss). Sin embargo, las especies de puesta múltiple repiten este proceso varias veces durante la época de puesta, como el caso de la lubina (Dicentrarchus labrax) que pone 3-4 veces por temporada.

c) Ovarios con desarrollo asíncrono. En este caso el ovario posee oocitos en todos los estados de desarrollo. Es característico de especies que ponen en repetidas ocasiones a lo largo de un dilatado periodo anual de puesta, como la medaka (Oryzias latipes) y el pez rojo o carpin (Carassius auratus.).

\section{Oogénesis}

La oogénesis es el proceso de formación de gametos femeninos. Un proceso en el que a partir de oogonias se desarrollan óvulos listos para ser fecundados. En peces, durante la oogénesis se pueden distinguir cinco fases principales: 1) proliferación oogonial, 2) crecimiento primario, 3) crecimiento secundario, 4) maduración y 5) ovulación (Le Menn et al., 2007; Planas y Swanson, 2008).

Después de la diferenciación sexual, en el ovario, las CGPs se van diferenciando en oogonias. Posteriormente, al comienzo o durante cada ciclo reproductivo, tiene lugar una fase de proliferación oogonial que tras varias divisiones mitóticas, inician su primera división meiótica, que queda detenida en profase I, dando lugar a oocitos primarios que se aíslan y rodean de una capa plana de células foliculares (células de la granulosa y de la teca). Durante la profase I el núcleo de los oocitos pasa a través de cinco estados sucesivos: leptoteno, zigoteno, paquiteno, diploteno y diacinesis. El crecimiento primario del oocito tiene lugar durante los cuatro primeros estados de profase I e incluye la previtelogénesis que tiene lugar en el estado de diploteno (Le Menn et al., 2007). El crecimiento primario se caracteriza por la condensación, sinapsis y recombinación de cromosomas homólogos y la formación de las capas foliculares que rodean el oocito. El oocito aumenta extraordinariamente de tamaño y experimenta una serie de transforma- 
ciones que afectan al núcleo, nucleolo y citoplasma. Durante esta fase se expresan importantes genes necesarios para el desarrollo de la oogénesis, produciéndose una abundante síntesis de ARNm. Aparecen numerosos nucleolos en la periferia del núcleo (estado perinucleolar) y se sintetizan abundantes glicoproteínas que son incorporadas a los alvéolos corticales (estado de alveolo cortical). La profase I se para en el estado de diploteno durante un tiempo determinado que en los teleósteos puede variar entre unos pocos días y algunos meses. Durante esta parada meiótica tiene lugar la fase de crecimiento secundario, también conocida como vitelogénesis. Esta fase de crecimiento se caracteriza por la acumulación en el oocito de reservas nutricionales (gránulos de vitelo), vitaminas y hormonas que servirán para que culminen con éxito el desarrollo embrionario y larvario (Le Menn et al., 2007; Lubzens et al., 2010; Zanuy et al., 2009). La vitelogénesis implica la síntesis hepática de vitelogenina (VTG), y su incorporación en los oocitos en crecimiento. La VTG es una gran fosfolipoglicoproteína precursora de las proteínas del vitelo y de su correcta síntesis, acumulación y procesado depende la calidad del huevo y viabilidad de la larva (Lubzens et al., 2010). Finalmente el oocito entra en fase de maduración, proceso durante el cual se completa la primera división meiótica dando lugar al oocito secundario que progresa hasta metafase de la segunda división meiótica (metafase II). Durante este proceso, se produce condensación de los cromosomas y el núcleo del oocito (vesícula germinal o VG), que estaba inicialmente localizado en el centro del citoplasma, migra hacia el polo animal donde se disgrega. Después de este evento, denominado rotura de la vesícula germinal, tiene lugar la extrusión del primer corpúsculo polar (Fig. 4). Durante la maduración también se observan varios cambios en el citoplasma, como la fusión de gránulos de vitelo, clarificación del citoplasma y, en especies marinas, el aumento del tamaño del oocito por hidratación (Cerdà, 2009). Tras el proceso de hidratación, la envoltura folicular se rompe y el oocito fertilizable u ovulo es liberado al oviducto (ovulación). Por último, tras la fertilización finaliza la segunda división meiótica, detenida en metafase II.

Si durante la oogénesis, los oocitos no se desarrollan correctamente entran en atresia, proceso por el que los oocitos degeneran y son reabsorbidos por el ovario. 


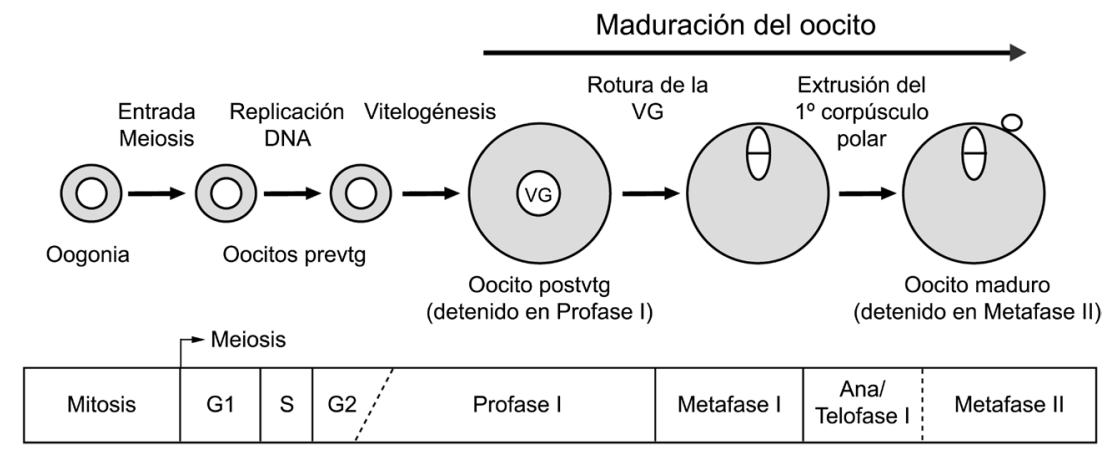

Figura 4. Representación esquemática del crecimiento y maduración del oocito. Los oocitos, producidos por la entrada en meiosis de oogonias, crecen de tamaño principalmente por la acumulación de vitelogenina (vitelogénesis). En respuesta a la estimulación hormonal, los oocitos detenidos en profase I (inmaduros) prosiguen la meiosis hasta metafase II (maduros). Vesícula germinal o núcleo (VG), previtelogénicos (prevtg), postvitelogénicos (postvtg). Adaptado de Suwa y Yamashita (2007).

\section{Control endocrino de la reproducción en teleósteos}

La reproducción en peces, como en otros vertebrados, está controlada por una red neuro-endocrina constituida por el cerebro, la glándula hipofisiaria y las gónadas. Esta red se denominada comúnmente eje cerebro-hipófisisgónada (eje CHG) (Fink, 2000) y es responsable de la cascada hormonal que regula el proceso reproductor. Con el fin de asegurar el éxito reproductivo y evitar condiciones ambientales inapropiadas, el cerebro integra los diferentes estímulos, externos e internos, y los traduce en señales neuroendocrinas que regulan el eje CHG. En líneas generales, el proceso se inicia con la síntesis cerebral del neuropéptido hormona liberadora de gonadotrofinas (GnRH), que induce la síntesis y secreción hipofisaria de dos gonadotrofinas (GTHs), la hormona folículo estimulante (FSH) y la hormona luteinizante (LH). Posteriormente, las GTHs llegan a las gónadas a través del torrente sanguíneo, donde actúan sobre el desarrollo gonadal y la gametogénesis mediante la estimulación de la síntesis de esteroides sexuales. A su vez, los esteroides gonadales actúan sobre la síntesis y liberación de GTHs, ejerciendo un feedback positivo o negativo según el estado de desarrollo gonadal, bien 
sea directamente sobre las células hipofisarias o indirectamente en ciertos núcleos hipotalámicos (Levavi-Sivan et al., 2010) (Fig. 5).

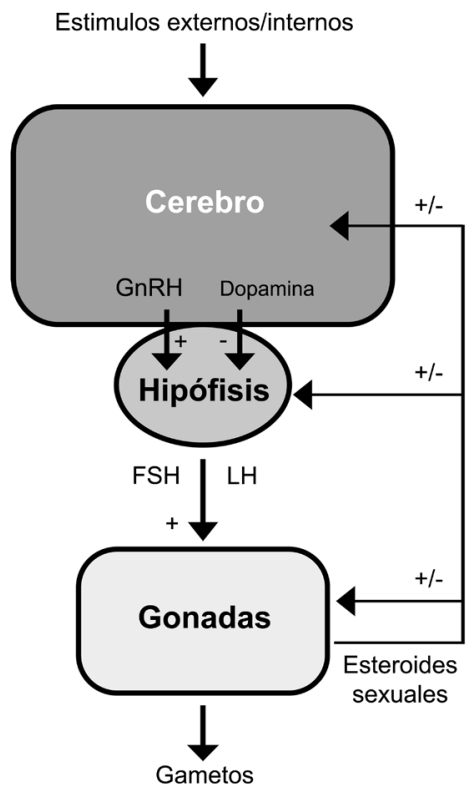

Figura 5. Representación esquemática del eje CHG en teleósteos. El símbolo + indica estimulación mientras que - representa inhibición.

\section{Cerebro}

$\mathrm{Al}$ cerebro se le ha atribuido un papel mediador de la influencia del medio ambiente sobre el proceso reproductor. Los estímulos ambientales son captados por los órganos sensoriales y trasmitidos al sistema nervioso central que responde mediante la liberación de determinados neuropéptidos y neurotransmisores. En los últimos años, el número de factores neuroendocrinos relacionados con el control del proceso reproductivo de los peces ha ido creciendo progresivamente. Entre ellos, la GnRH es considerada el principal factor cerebral implicado en la estimulación de la síntesis y secreción de las GTHs hipofisarias (Kah et al., 2007; Zohar et al., 2010). No obstante, existen otros factores cerebrales que modulan directa o indirectamente su liberación, como el neuropéptido Y (NPY), el acido gamma-amino butírico (GABA), la dopamina o las Kisspeptinas (Zohar et al., 2010). 


\section{Hormona liberadora de gonadotrofinas (GnRH)}

La GnRH es un decapéptido producido y secretado por neuronas localizadas en diferentes regiones del cerebro. En la década de los 70 se aisló por primera vez en el hipotálamo de mamíferos y se denominó de forma genérica GnRH por su capacidad de estimular la secreción de FSH y LH (Burgus et al., 1971; Matsuo et al., 1971). En realidad, el sistema GnRH es una familia de neuropéptidos y hasta la fecha, se han identificado un total de 26 isoformas con estructura molecular similar, 15 en vertebrados (Tabla 1) y 11 en invertebrados (Kavanaugh et al., 2008). Tradicionalmente las isoformas de GnRH han recibido el nombre de las especies en las que fueron descritas por primera vez, si bien pueden estar presentes en diferentes especies. La mayoría de vertebrados expresan dos o tres formas de GnRH, aunque en zonas diferentes y aparentemente ejerciendo funciones distintas (Kah et al., 2007; Muñoz-Cueto, 2009). Para evitar confusiones, se propuso una nueva nomenclatura atendiendo a criterios filogenéticos y neuroanatómicos y las diferentes formas de GnRH se agruparon en tres tipos, GnRH-1, GnRH-2 y GnRH-3 (Fernald y White, 1999). Posteriormente, Silver et al. (2004) sugirieron un cuarto grupo (GnRH-4).

El tipo GnRH-1 engloba todas las formas hipofisiotróficas de GnRH de gnatóstomos (vertebrados con mandíbula), que son la mayoría de las formas descritas. Se expresan principalmente en neuronas del hipotálamo y del área preóptica de vertebrados, desde donde envían proyecciones axonales a la hipófisis. El tipo GnRH-2 se corresponde con la GnRH II de pollo (cGnRH-II) y se expresa de forma conservada en el sinencéfalo/mesencéfalo de todos los vertebrados, desde peces hasta mamíferos. No hay evidencias claras sobre la función de GnRH-2, aunque se le atribuye acciones neuromoduladoras y/o conductuales (Muñoz-Cueto, 2009). Recientemente se ha descrito otra forma de GnRH en lamprea (lGnRH-II) que deriva de una forma ancestral común a cGnRH-II, pero se expresa en el área preóptica e hipotálamo y se le atribuye una acción estimuladora de la hipófisis (Kavanaugh et al., 2008). El tercer tipo, GnRH-3, se corresponde exclusivamente con la forma GnRH de salmón (sGnRH), y hasta la fecha sólo se ha identificado de forma concluyente en el cerebro anterior de peces. Como en el caso del tipo I, en numerosas especies de peces, las neuronas secretoras de GnRH-3 envían fibras nerviosas a la hipófisis. Su función no está del todo clara, pero se piensa que podría participar junto al tipo GnRH-1 en la regulación de la síntesis de 


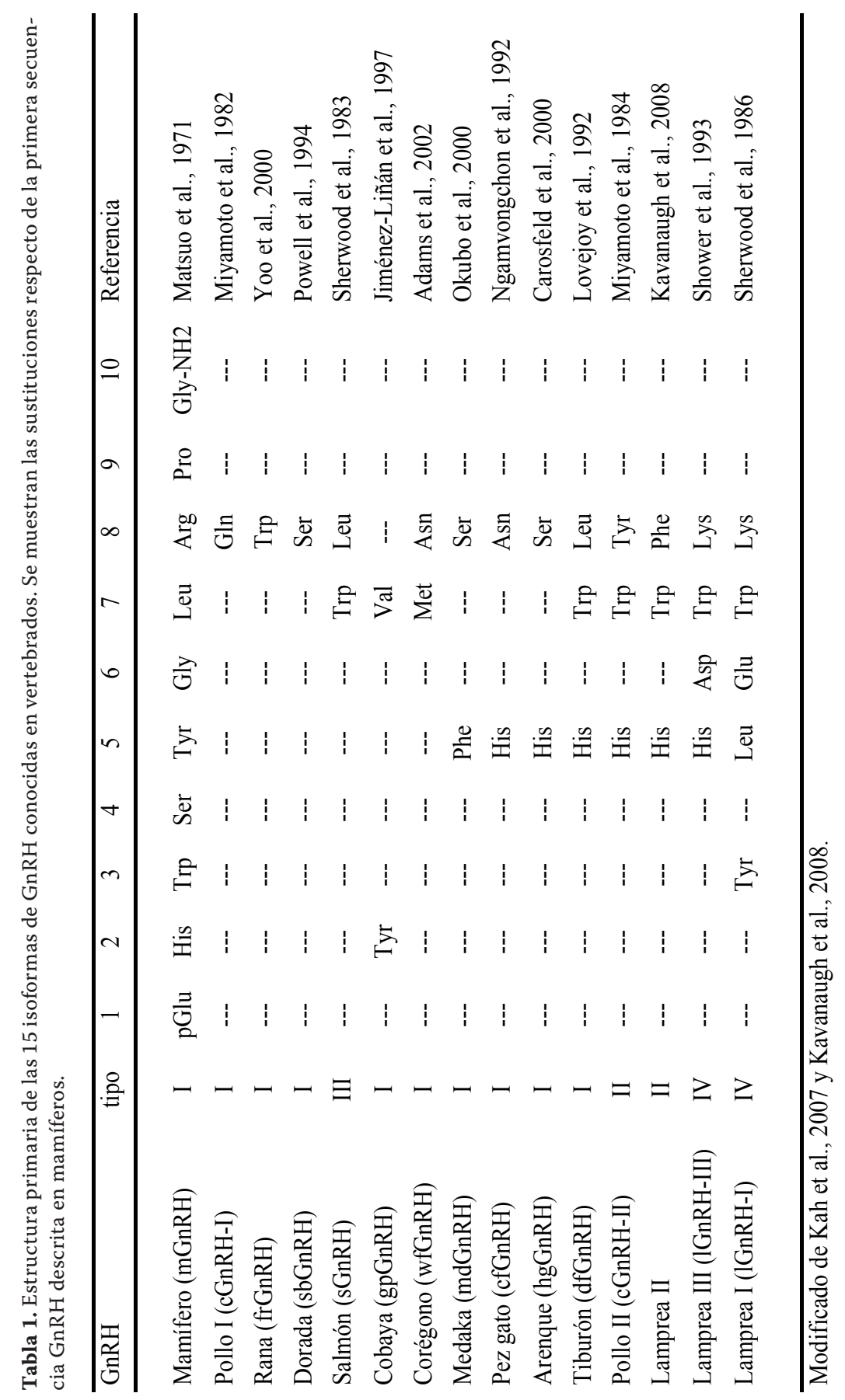


GTHs y en la conducta reproductiva junto al tipo GnRH-2 (Muñoz-Cueto, 2009). Por último, el tipo GnRH-4 parece exclusivo de los agnatos (vertebrados sin mandíbula) y engloba a dos de las tres GnRHs descritas en lamprea (lGnRH-I y lGnRH-III). Se expresan en el área preóptica e hipotálamo y se les atribuye una acción hipofisiotrófica (Kavanaugh et al., 2008; Silver et al., 2004).

Estudios realizados en Perciformes, como la lubina, han puesto de manifiesto que expresan tres formas de GnRH, sbGnRH (GnRH-1), cGnRH-II (GnRH-2), y sGnRH (GnRH-3) (Muñoz-Cueto, 2009). Aunque las tres formas tienen una clara acción estimuladora sobre la liberación de GTHs hipofisarias (Zohar et al., 1995), estudios inmunohistoquímicos realizados en la lubina demuestran que las neuronas productoras de GnRH-1 y GnRH-3 inervan directamente la hipófisis, mientras que las de GnRH-2 no envían fibras nerviosas a la misma. No obstante, como en otros Perciformes, la inervación GnRH-1 es la más abundante en la hipófisis y la principal forma hipofisiotrófica, implicada en la regulación de la síntesis y secreción de GTHs (Gonzalez-Martinez et al., 2002a).

\section{Receptores de GnRH (GnRHRs)}

Las GnRHs ejercen su acción tras unirse a receptores específicos (GnRHR) presentes en las membranas de las células diana. Los GnRHR pertenecen a la superfamilia de receptores acoplados a proteínas $\mathrm{G}$ y poseen una sola cadena polipeptídica con siete dominios transmembrana separados por giros hidrófilos extra e intra-celulares de extensión variable (Sealfon et al., 1997). La interacción de GnRH con su receptor desencadena una cascada de reacciones intracelulares que conduce a la producción de segundos mensajeros. En los últimos años se han clonado y caracterizado distintos receptores de $\mathrm{GnRH}$ presentes en diferentes especies de peces (Kah et al., 2007; Lethimonier et al., 2004). Los primeros receptores fueron detectados en la hipófisis, aunque también se han encontrado en tejidos extrahipofisarios como el cerebro, las gónadas, el hígado o el riñón, reforzando la idea de que las GnRHs no solo ejercen acciones reproductivas a nivel de la hipófisis, sino que pueden actuar como neurotransmisores y/o neuromoduladores en el cerebro, y como factores autocrinos o paracrinos en las gónadas (MuñozCueto, 2009). En la lubina se han caracterizado 5 tipos de receptores (Gonzalez-Martinez et al., 2004; Moncaut et al., 2005), de los cuales solo el tipo dlGnRHRII-1a, también denominado dlGnRHR-2A, está altamente expre- 
sado en las células gonadotropas de la hipófisis y presenta afinidad por las formas sbGnRH y sGnRH (Gonzalez-Martinez et al., 2004; Kah et al., 2007). Además, este receptor dlGnRHRII-1a muestra diferencias en su expresión durante el ciclo reproductor (Gonzalez-Martinez et al., 2004), lo que sugiere un papel relevante en el control de la secreción de GTHs.

\section{Hipófisis}

La hipófisis o pituitaria es una pequeña glándula endocrina adosada a la parte ventral del cerebro de todos los vertebrados. En ella se sintetizan importantes hormonas implicadas en la regulación de la mayoría de los procesos biológicos del organismo. La hipófisis consta de una porción nerviosa, la neurohipófisis, formada por axones de neuronas que se proyectan desde el cerebro y una porción endocrina, la adenohipófisis, constituida por células secretoras no nerviosas. A su vez, en teleósteos, la adenohipófisis puede dividirse en tres regiones, la pars distalis rostral (PDR), la pars distalis proximal (PDP) y la pars intermedia (PI). En general, en la PDR se localizan las células lactotropas y corticotropas; en la PDP las células somatotropas, tirotropas y gonadotropas; y en la PI se localizan las células melanotropas, somatolactotropas y en ocasiones, en los bordes, también gonadotropas (Weltzien et al., 2004). A diferencia de los vertebrados superiores, diversos estudios inmunohistoquímicos han demostrado que en los peces, la FSH y la LH se producen en células gonadotropas diferentes (Levavi-Sivan et al., 2010).

\section{Gonadotrofinas (GTHs)}

Durante muchos años se pensó que en la hipófisis de los peces se producía una sola GTH, a la que se le atribuía la regulación de todo el proceso reproductor (Burzawa-Gerard y Fontaine, 1972). A mediados de la década de los 80, Idler y Ng (1983) propusieron un sistema dual para las GTHs de los teleósteos que no quedó totalmente establecido hasta la identificación de dos GTHs diferentes en la hipófisis de salmón chum (Onchorhynchus keta), GTH-I y GTH-II (Kawauchi et al., 1986). Desde entonces, aunque se ha demostrado la existencia de dos GTHs en numerosas especies de teleósteos, solo se han aislado y caracterizado en un reducido número de especies (Tabla 2).

A finales de los 90, en base a las secuencias de nucleótidos que codifican las GTHs y sus predicciones aminoacídicas, se estableció la homología entre 


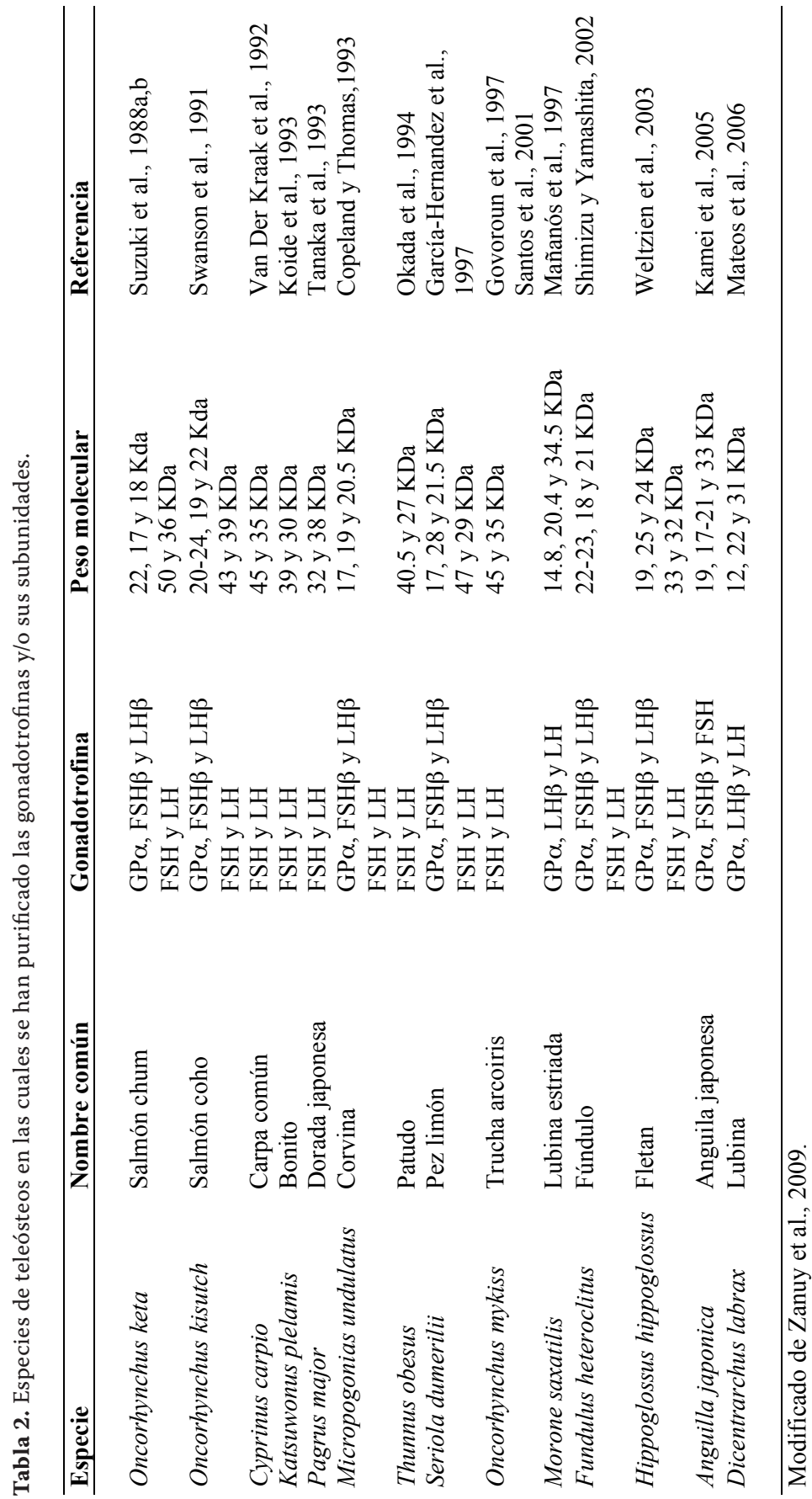


la GTH-I y la GTH-II de peces con la FSH y la LH de tetrápodos, respectivamente (Li y Ford, 1998; Querat et al., 2000).

\section{Estructura de las gonadotrofinas}

Las GTHs forman parte, junto con la gonadotrofina coriónica placentaria (CG) y la tirotrofina hipofisaria (TSH), de una familia de hormonas glicoproteicas evolutivamente conservadas. Estas hormonas son heterodímeros relacionados estructuralmente, compuestos por la asociación no covalente de una subunidad $\alpha$ (GP $\alpha$; también denominada Cga) común dentro de una misma especie y una subunidad $\beta$ especifica que determina la actividad biológica y la especificidad de la hormona (Bousfield et al., 1994; Pierce y Parsons, 1981). Recientemente se ha incorporado a este grupo de glicoproteínas un nuevo miembro, la tiroestimulina (Nakabayashi et al., 2002) con la particularidad de que no comparte la misma subunidad $\alpha$ que el resto y cuya síntesis se ha detectado en numerosos tejidos aparte de la hipófisis. Las subunidades gonadotropas (GP $\alpha, \mathrm{FSH} \beta$ y LH $\beta$ ) están codificadas por genes parálogos, descendientes de un gen ancestral común (Li and Ford, 1998). La dimerización y glicosilación es un requisito imprescindible para que las GTHs alcancen su actividad biológica completa, de manera que las subunidades por si mismas son biológicamente inactivas (Pierce y Parsons, 1981). Las secuencias de aminoácidos de las subunidades $\alpha$ y $\beta$ conocidas contienen una proporción alta de residuos de cisteína (Cys) localizados en posiciones conservadas. Estos residuos de Cys, que generalmente son 10 en la subunidad $\alpha$ y 12 en las subunidades $\beta$, forman 5 y 6 puentes disulfuro intracatenarios, respectivamente (Hearn y Gomme, 2000) (Fig. 6). La determinación de la estructura cristalina de la CG y la FSH humana mediante difracción de rayos X (Fan y Hendrickson, 2005; Fox et al., 2001; Lapthorn et al., 1994) ha permitido conocer mejor su estructura. A pesar de las considerables diferencias en la secuencia de aminoácidos, las subunidades $\alpha$ y $\beta$ comparten una organización estructural similar. Modelos de estructura terciaria de las subunidades gonadotropas de peces sugieren que como en mamíferos, estas subunidades pertenecen a una superfamilia de proteínas caracterizadas por la presencia de un nudo de Cys, "cystine knot", formado por tres puentes disulfuro intracatenarios entre seis Cys que es crítico para el correcto plegamiento y dimerización de las subunidades (Hearn y Gomme, 2000). Desde el nudo de Cys salen tres lazos de horquilla $\beta$ que se extienden dos hacia un lado de la molécula (L1 y L3; Fig. 6) y un tercero en sentido opuesto (L2; Fig. 
6). Cuando se forma el heterodímero, las dos subunidades se asocian en un posicionamiento del tipo "cabeza-cola", formando una estructura alargada con los lazos $\beta$ L2, $\alpha$ L1 y $\alpha$ L3 hacia un extremo y los lazos $\alpha L 2, \beta L 1$ y $\beta L 3$ hacia el opuesto (Fig. 6). La unión entre las dos subunidades se realiza de forma no covalente y se estabiliza mediante un lazo del extremo $C$-terminal de la subunidad $\beta$ que envuelve a $\alpha$ L2 como un "cinturón de seguridad" y se ancla a $\beta \mathrm{L} 1$ por un puente disulfuro entre las Cys conservadas 3 y 12 (Fig. 6). Además de estabilizar el heterodímero, esta zona "cinturón de seguridad",
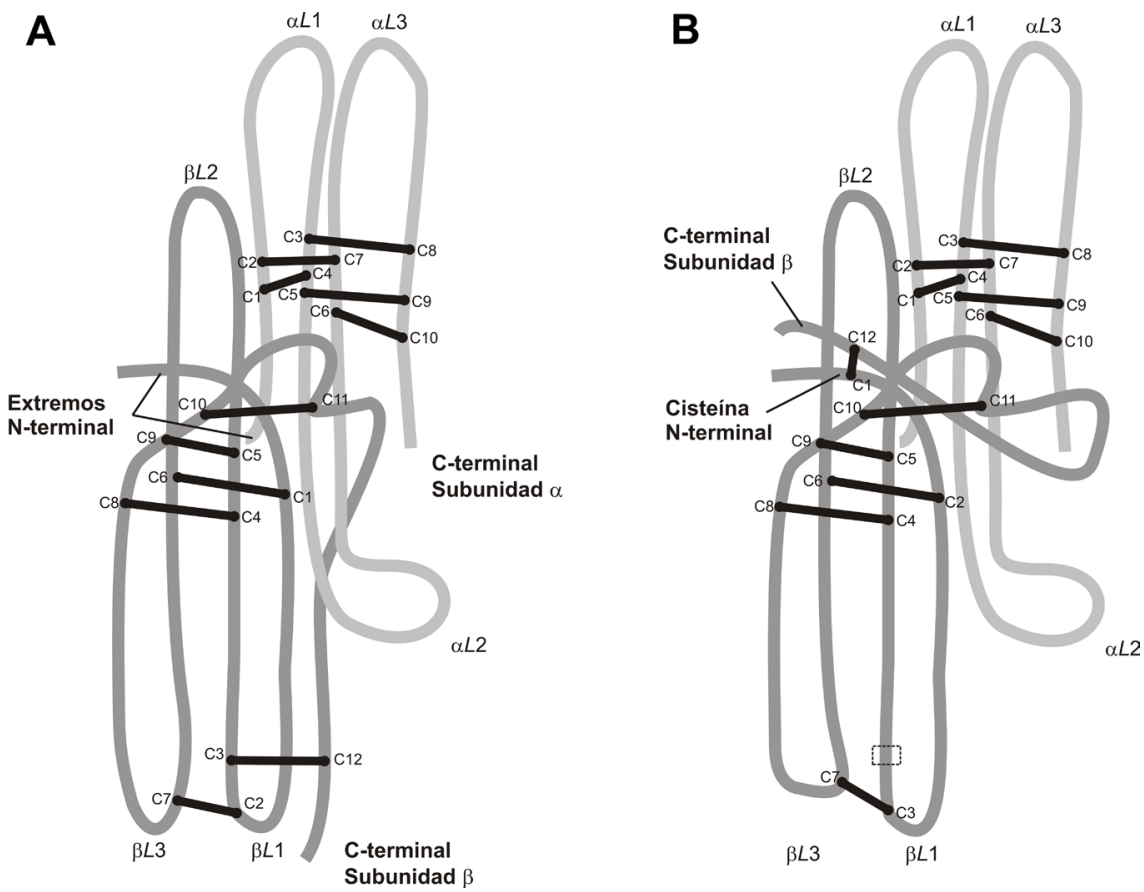

Figura 6. Representación esquemática de la estructura tridimensional de dos patrones de plegamiento de hormonas glicoproteicas encontrados en vertebrados. Los heterodímeros están compuestos por una subunidad $\alpha$ (gris claro) y una subunidad $\beta$ (gris oscuro) que se alinean en un posicionamiento "cabeza-cola". Cada subunidad contiene un nudo central de cisteínas que divide el polipéptido en tres lazos de horquilla (ver texto). La asociación no covalente del heterodímero es estabilizada por un lazo de la subunidad $\beta$ denominado "cinturón de seguridad" que se envuelve alrededor de $\alpha \mathrm{L} 2$ y se ancla a $\beta \mathrm{L} 1$. (A) Patrón de plegamiento presente en las glicoproteínas de tetrápodos. (B) Patrón de plegamiento de algunas FSH de peces teleósteos. En algunas subunidades $\beta$ FSH de peces falta la tercera cisteína conservada en $\beta$ L1 (rectángulo discontinuo abierto), y se ha sugerido que sus "cinturones de seguridad" se anclan a una cisteína del extremo $\mathrm{N}$-terminal. Esto se traduce en una marcada diferencia en la ubicación espacial de los residuos entre la undécima y duodécima cisteínas de la subunidad $\beta$. Adaptado de Rocha (2008). 
parece que también esta implicada en la especificidad de unión al receptor y transducción de la señal (Moyle et al., 1994).

Análisis filogenéticos de subunidades gonadotropas de peces han mostrado que la subunidad $\alpha$ es la más conservada entre las diferentes especies y que la subunidad FSH $\beta$ ha evolucionado a un mayor ritmo que la LH $\beta$ (Querat et al., 2004). Al contrario que en la FSH $\beta$, en las subunidades LH $\beta$ las posiciones de los 12 residuos de Cys y el único sitio potencial de $N$-glicosilación, están estrictamente conservados. Lo mismo sucede con las regiones consideradas importantes para la interacción con el receptor como la zona "cinturón de seguridad" (Swanson et al., 2003). Sin embargo, en la mayoría de teleósteos, excepto en los más primitivos, la FSH $\beta$ se desvía de la estructura básica de tetrápodos con 12 residuos Cys conservados y dos sitios potenciales de $N$-glicosilación. En la FSH $\beta$ de Salmónidos, Perciformes y Pleuronectiformes falta la tercera Cys conservada y el segundo sitio de $N$ glicosilación y tiene una Cys adicional cerca del extremo N-terminal (Fig. 6) que altera la conformación del "cinturón de seguridad”. Dado la importancia en las interacciones con el receptor y en la estabilidad del heterodímero, la variación estructural de esta región entre las $\mathrm{FSH} \beta$ de algunas especies de peces podría dar lugar a diferencias considerables entre ellas. Además, la perdida del segundo sitio de $N$-glicosilación podría afectar a su potencia biológica ya que los oligosacáridos alteran la vida media de las glicoproteínas y en algunos casos las interacciones con el receptor (Swanson et al., 2003).

Los pesos moleculares de las GTHs, estimados en diferentes especies de teleósteos, oscilan entre 12-28 KDa para las subunidades y 27-50 KDa para los dímeros (Zanuy et al., 2009) (Tabla 2). La porción glicosídica contribuye entre un 20 y un $40 \%$ de la masa total de las GTHs y desempeña un importante papel en muchas de las características funcionales de las mismas. Los oligosacáridos influyen en el correcto plegamiento de las subunidades, en el ensamblaje del dímero, en el almacenamiento intracelular y secreción, en la unión a su receptor, transducción de la señal y en la vida media de la hormona (Hearn y Gomme, 2000; Ulloa-Aguirre et al., 2003). El proceso de $N$-glicosilación empieza en el Retículo Endoplasmático Rugoso (RER) y termina en el Aparato de Golgi (AG), donde finalmente se obtiene la proteína madura con las modificaciones necesarias para ser secretada al torrente sanguíneo. Los oligosacáridos se unen a las GTHs mediante enlaces $N$ glicosídicos con residuos de Asparagina (Asn) en determinadas secuencias 
potenciales de glicosilación (Asparagina-X-Serina/Treonina, donde X puede ser cualquier aminoácido excepto Prolina). La composición de los oligosacáridos en las hormonas glicoproteicas es altamente variable y depende en gran parte del tipo celular que las sintetiza. Además, dentro de una misma glicoproteína, puede encontrarse diferentes grados de glicosilación, constituyendo esta la principal base química para la formación de isoformas. En general, las $N$-glicosilaciones pueden agruparse en tres grandes categorías o subtipos: 1) subtipo de alto contenido en manosa, 2) subtipo complejo y 3) subtipo híbrido (Fig.7).

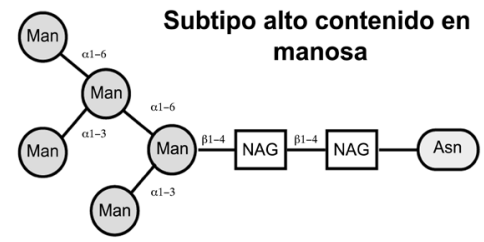

Subtipo complejo
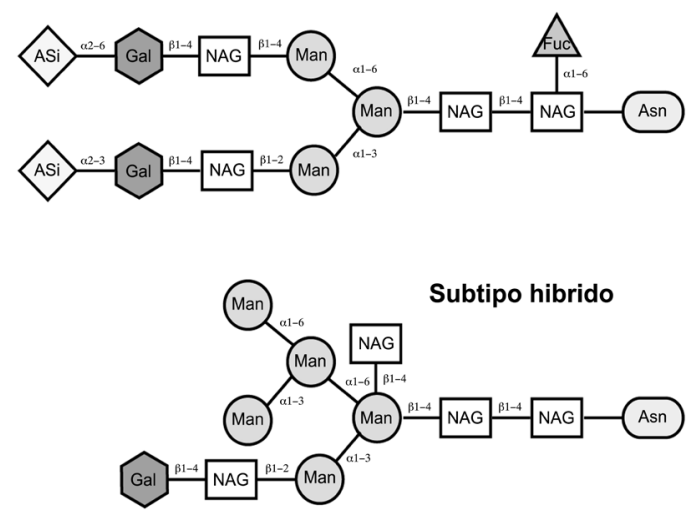

Figura 7. Estructura general de los tres principales subtipos de oligosacáridos encontrados en las isoformas de las hormonas glicoproteicas: subtipo alto contenido en manosa, subtipo complejo y subtipo hibrido. Los oligosacáridos se unen a determinadas aminoácidos de Asparragina (Asn) de la proteína y están compuestos por diversos residuos de azúcar: manosa (Man), $\mathrm{N}$-acetilglucosamina (NAG), fucosa (Fuc) galactosa (Gal) y acido siálico (ASi). Adaptado de Hearn y Gomme (2000), y Gates et al., (2004). 


\section{Función de las gonadotrofinas}

Las GTHs son esenciales en el control de la reproducción de todos los vertebrados. Como se comento anteriormente, se sintetizan en las células gonadotropas de la adenohipófisis, que en los peces estan situadas en la PDP y en ocasiones, en el borde de la PI. Una vez liberadas al torrente sanguíneo actúan sobre las gónadas a través receptores específicos, regulando la gametogénesis a través de su mediación en la producción de esteroides sexuales. A diferencia de los tetrápodos, donde está bien establecido el papel de cada GTH, en la mayoría de teleósteos no existe una información clara sobre sus diferentes funciones. En general, en peces existen pocos estudios donde se compara directamente la actividad de FSH y de LH debido a la ausencia de herramientas apropiadas para su estudio, principalmente de ensayos para determinar los niveles de FSH. A pesar de la reconocida importancia de ambas GTHs en la reproducción, falta información en procesos críticos como la diferenciación sexual, pubertad o gametogénesis. El acceso a fracciones puras y bioactivas de GTHs es fundamental para desarrollar ensayos y estudiar sus funciones en cada especie o grupo de especies. En las ultimas dos décadas se han desarrollado numerosos inmunoensayos para determinar LH en diferentes especies de peces, por contra, para FSH únicamente se han desarrollado en unas pocas, principalmente Salmónidos (Tabla 5). De los resultados obtenidos a partir de los inmunoensayos disponibles en estas especies (Tabla 3), se desprende que en salmónidos la FSH regula las fases iniciales de crecimiento y desarrollo gonadal (vitelogénesis e inicio espermatogénesis) mientras que la LH controla los procesos finales de maduración de los gametos, la ovulación en hembras y la espermiación en machos (Levavi-Sivan et al., 2010). En tilapia (Oreochromis niloticus) - la única especie no salmónido en la que se dispone de inmunoensayo para FSH - se ha observado un aumento de los niveles de ambas GTHs durante la vitelogénesis, sugiriendo que en este Perciforme la LH podría jugar un papel no solo durante la maduración de los oocitos sino también durante la vitelogénesis (Aizen et al., 2007). Por otro lado, estudios in vitro han demostrado que ambas GTHs estimulan la producción testicular de 11-ketotestosterona (11KT) durante el proceso de espermatogénesis en Salmónidos (Planas y Swanson, 1995) y Perciformes (Kagawa et al., 1998b), así como la producción de $17 \beta$-estradiol (E2) en ovarios vitelogénicos de Cipriniformes, Perciformes y Salmónidos (Okada et al., 1994; Planas et al., 2000; Suzuki et al., 1988c; 


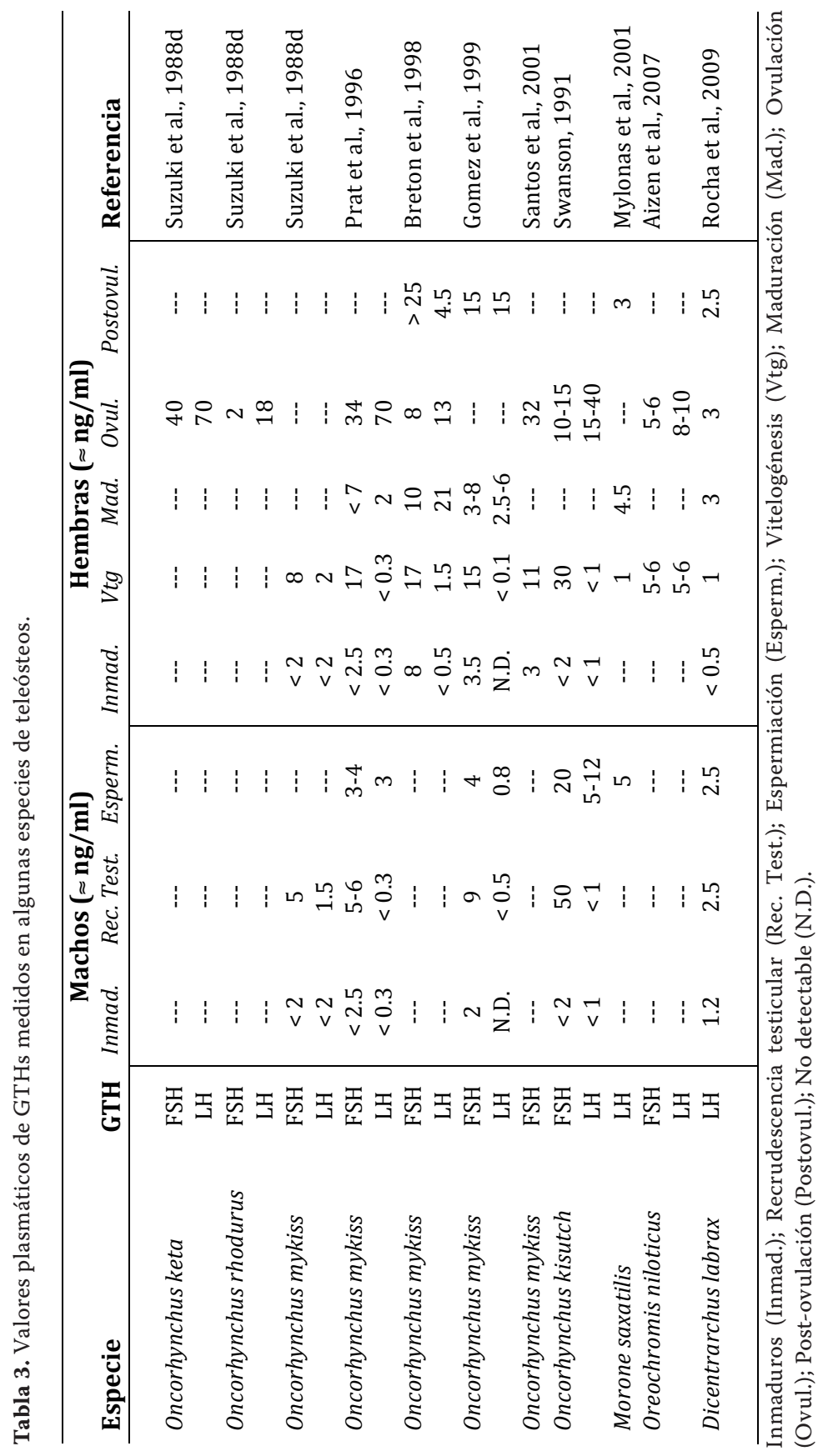


Van der Kraak et al., 1992). Sin embargo, estos estudios mostraron que la potencia esteroidogénica de la LH excede a la de FSH a medida que avanza la espermatogénesis y la maduración de los oocitos. Este incremento de la potencia de LH respecto FSH coincide con la aparición del receptor de LH en el testículo, la espermiación, el cambio en la esteroidogénesis ovárica de E2 a $17 \alpha, 20 \beta$-dihidroxi-4-pregnen-3-ona (17,20ßP) y con la rotura de la vesícula germinal (Swanson et al., 2003). La única función descrita hasta el momento exclusiva de la FSH es su participación en la incorporación de vitelogenina en los oocitos (Tyler et al., 1997; Tyler et al., 1991). Mas recientemente, se ha demostrado también que la FSH regula la expresión de ciertos genes como la conexina (cx34.3), clusterina 1 (clu1), fibronectina (fn) y decorina (dcn), los cuales podrían estar involucrados en la comunicación celular, diferenciación de las células foliculares y remodelado de la estructura del folículo ovárico (Luckenbach et al., 2011).

En la última década, la biología molecular ha abierto nuevas posibilidades en el estudio de las funciones de las GTHs. La disponibilidad de sus secuencias codificantes ha permitido desarrollar métodos de análisis de expresión génica que ofrecen información indirecta sobre la síntesis GTHs mediante la medición de la actividad transcripcional (ARNm) de los genes que las codifican. Aunque los niveles de ARNm no reflejan necesariamente los niveles de hormona circulante, en Salmónidos los perfiles de expresión génica de ambas hormonas en la hipófisis se han correlacionado con sus niveles plasmáticos a lo largo del ciclo reproductor (Gomez et al., 1999), incrementando los niveles de ARNm de FSH $\beta$ antes que los de LH $\beta$. En peces no Salmónidos como la anguila japonesa (Anguilla japonica), el esturión del Danubio (Acipenser gueldenstaedtii), el congrio del Pacífico (Conger myriaster) y la tilapia se han encontrado resultados similares, con altos niveles de expresión de FSH $\beta$ en estados tempranos de la gametogénesis y una expresión predominante de LH $\beta$ en fases finales de maduración, ovulación y espermiación. Sin embargo, en otras especies con desarrollo gonadal asíncrono o de puestas múltiples como el pez rojo (Carassius auratus), la dorada japonesa (Pagrus major), la lubina, la lubina estriada (Morone saxatilis) y el falso halibut del Japón (Paralichthys olivaceus), se ha observado una activa expresión de la subunidad FSH $\beta$ durante la fase de maduración gonadal (Levavi-Sivan et al., 2010). Además, en algunas especies como el pez rojo y la lubina los perfiles de expresión de ambas subunidades, LH $\beta$ y FSH $\beta$, fluctúan de manera similar (Mateos et al., 2003; Sohn et al., 1999). Es posible que esta fluctuación 
paralela de ambas GTHs en peces de puesta múltiple, refleje una regulación diferente por cada GTH de las distintas generaciones de oocitos presentes al mismo tiempo en el ovario (Levavi-Sivan et al., 2010).

Además de regular los procesos de gametogénesis en individuos adultos, la detección temprana de GTHs también sugiere que podrían participar en procesos tan importantes como la diferenciación sexual (Devlin y Nagahama, 2002). Apenas unos pocos estudios se han centrado en este aspecto pero de ellos se desprende que las GTHs y en particular la FSH, juegan un papel critico en la diferenciación sexual, tanto en especies gonocoristas como en hermafroditas (Kobayashi et al., 2010b; Pandolfi et al., 2006; Yamaguchi et al., 2007). En este sentido, mediante técnicas inmunohistoquímicas se ha visto que las poblaciones hipofisarias de células secretoras de FSH aparecen antes de la diferenciación sexual mientras que las de LH surgen varios días después de iniciado el proceso o justo al final (Feist y Schreck, 1996; Magliulo-Cepriano et al., 1994; Pandolfi et al., 2006; Saga et al., 1993).

\section{Clonación y producción de gonadotrofinas recombinantes}

Desde la década de los 80 hasta la fecha se han aislado y caracterizado las secuencias codificantes de las subunidades gonadotropas en 56 especies de peces, representadas en al menos 14 ordenes de teleósteos (Levavi-Sivan et al., 2010). La clonación de las subunidades gonadotropas ha permitido comparar las secuencias de nucleótidos y de aminoácidos en diversos vertebrados, demostrando que la GTH I y GTH II de peces son homologas a la FSH y LH de tetrápodos (Querat et al., 2000). Además, la disponibilidad de estas secuencias ha supuesto un gran avance en el estudio del proceso reproductor de los teleósteos, permitiendo caracterizar estos genes y desarrollar herramientas moleculares para estudiar los perfiles de expresión en determinados momentos del proceso reproductor. Por otra parte, la clonación de las tres subunidades gonadotropas ha abierto la posibilidad de usar técnicas de ADN recombinante para producir FSH y LH de diversas especies. Durante muchos años, las GTHs de peces se han obtenido mediante purificación a partir de hipófisis, un proceso altamente costoso que no siempre llega a buen termino. En la última década, la producción de GTHs recombinantes se muestra como una alternativa excelente a las hormonas nativas ya que pueden ser producidas continua y selectivamente, asegurando su disponibilidad y evitando la contaminación cruzada con otras glicoproteínas hipofisarias. En líneas generales, la metodología consiste en la inserción de 
los ADN codificantes de las subunidades gonadotropas en vectores de expresión (plásmidos o virus) para transformar o transfectar diferentes líneas celulares u organismos heterólogos, donde, bajo el control de promotores fuertes, se expresan las GTHs en grandes cantidades. Esta metodología permite el suministro continuado de GTHs y elimina la necesidad de sacrificar cientos o miles de animales para purificar las hormonas nativas.

Para la producción de GTHs recombinantes se han usado diferentes sistemas de expresión, tanto procariotas como eucariotas. Los sistemas procariotas tienen la ventaja de su fácil manejo y bajo coste, pero presentan el inconveniente de carecer de los orgánulos celulares necesarios para procesar correctamente proteínas complejas como las GTHs. Por el contrario, los sistemas eucariotas poseen la maquinaria celular adecuada para realizar las modificaciones post-traduccionales necesarias y asegurar la completa bioactividad de estas glicoproteínas. Desde que se empezó a usar esta metodología en peces, se han producido varias subunidades libres y dimeros GTHs recombinantes de diferentes especies en distintos sistemas de expresión (Tabla 4). La producción de dímeros recombinantes se ha logrado de varias formas, mediante co-transfección de dos vectores de expresión, cada uno con el ADN codificante de una subunidad, por transfección con un único vector con ambos ADNs o mediante transfección con un vector con ambos ADN codificantes unidos que da lugar a proteínas de fusión o de cadena única (scGTHs).

Entre los sistemas de expresión eucariotas más usados para la producción de GTHs de peces se encuentran: - líneas celulares de la palomilla del maíz (Spodoptera frugiperda) (Sf9, Sf21) o larvas enteras del gusano de seda (Bombyx mori), infectadas con baculovirus modificados, - líneas celulares de mamíferos, como las de ovario de hamster chino (CHO) transfectadas con plásmidos, o - cultivos de la levadura Pichia pastoris (GS115, KM71) transformados con plásmidos. Todos estos sistemas de expresión han dado lugar a GTHs de peces biológicamente activas, aunque cada uno con unas ventajas e inconvenientes. La producción de subunidades libres y dímeros recombinantes tienen diversas aplicaciones, entre las que destacan: - su uso en estudios básicos de estructura y función, - el uso de FSH $\beta$ y LH $\beta$ como antígenos para la producción de anticuerpos específicos, esenciales para el desarrollo de inmunoensayos, y - la administración in vivo en aplicaciones biotecnológicas o terapéuticas (Levavi-Sivan et al., 2010). 


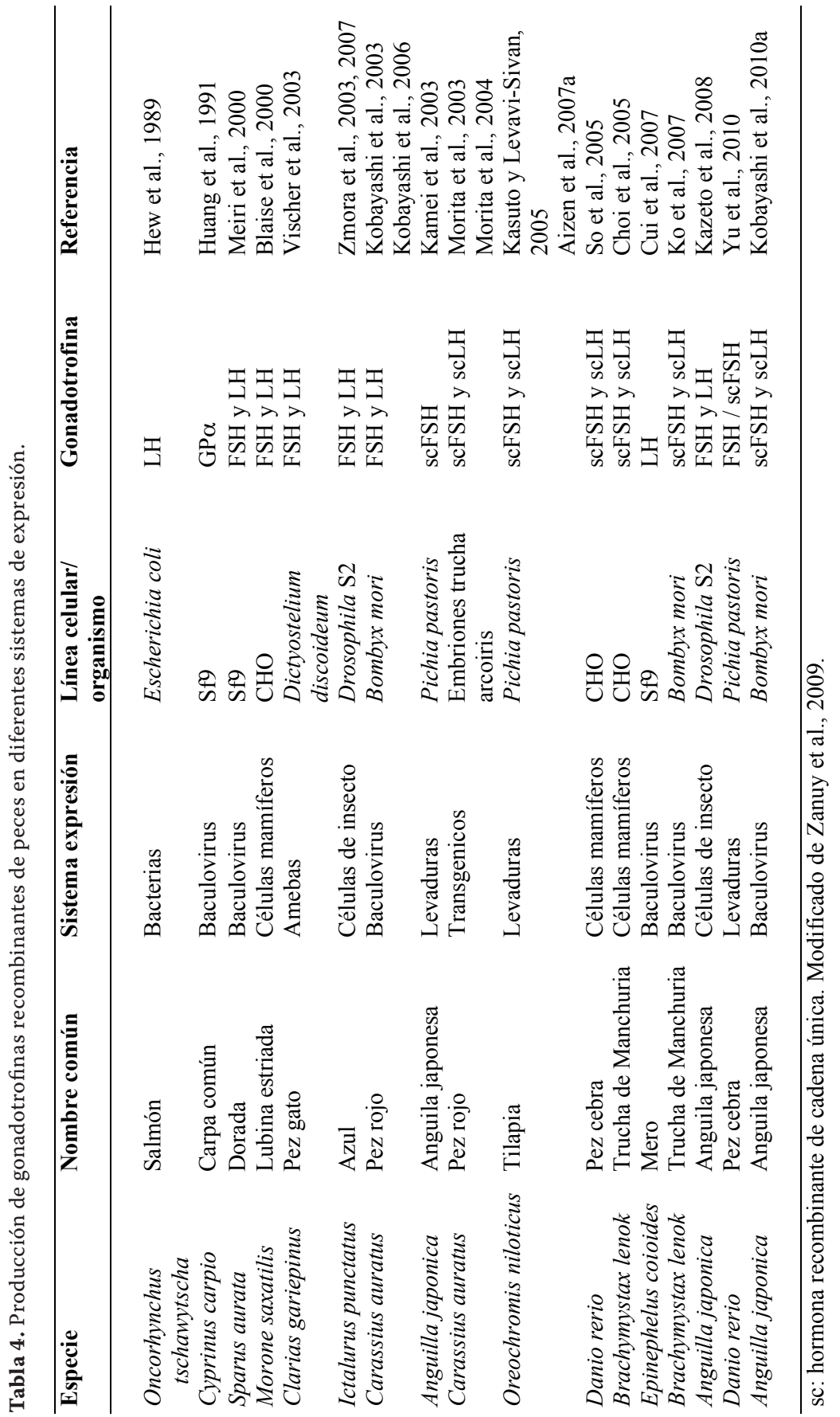




\section{Receptores de GTHs (GTHRs)}

Los receptores de FSH y LH (FSHR y LHR) junto con el de TSH (TSHR) constituyen una subfamilia de receptores de hormonas glicoproteicas (GpHRs) dentro de la gran familia de receptores acoplados a proteínas $G$ (GPCRs) (Vassart et al., 2004). En peces, los GTHRs se expresan predominantemente en las gónadas, concretamente en la superficie de las membranas de las células foliculares de la teca (FSHR) y de la granulosa (FSHR y LHR), en las células de Leyding (FSHR y LHR) y en las de Sertoli (FSHR). Sin embargo, también se ha descrito la presencia de transcritos de FSHR y LHR en numerosos tejidos extragonadales como el riñón y el cerebro, si bien se desconoce su significado biológico (Levavi-Sivan et al., 2010).

\section{Estructura}

Los GTHRs están constituidos por una sola cadena proteica en la que se pueden identificar un gran dominio extracelular $\mathrm{N}$-terminal, una región transmembrana con siete hélices alfa y un dominio intracelular C-terminal. Una de las principales características de los GTHRs es su gran dominio extracelular que constituye más de la mitad del receptor y esta involucrado con el reconocimiento y afinidad de unión al ligando (Ascoli et al., 2002; Dias et al., 2002). El dominio extracelular de los GTHRs tiene una porción central, tradicionalmente reconocida como la zona de unión al ligando, que contiene diez repeticiones ricas en leucina (LRR), flanqueadas por dos regiones ricas en cisteínas que protegen el centro hidrofóbico de las LRR. Además del papel protector, se cree que estas regiones ricas en cisteínas también podrían estar involucradas en el reconocimiento y unión al ligando, así como en la transducción de la señal (Fan y Hendrickson, 2005; Vassart et al., 2004).

A pesar de la elevada similitud estructural entre los GTHRs de los peces y los mamíferos, se pueden observar algunas diferencias importantes, sobre todo en los FSHRs. Contrariamente a lo observado en los FSHRs y LHRs de los mamíferos y en otras proteínas con dominios LRR, los FSHRs de los peces presentan notables diferencias en la región rica en cisteínas que bordea el extremo N-terminal del dominio LRR (Maugars y Schmitz, 2006; Oba et al., 1999a; Oba et al., 1999b; Rocha et al., 2007; Sambroni et al., 2007). Además, hay una delección de 30 aminoácidos en la región que bordea el extremo C-terminal del dominio LRR. Por otra parte, en los FSHRs de los peces Perciformes descritos hasta el momento existe una inserción de 25 aminoácidos, en la porción central del dominio extracelular, la cual 
representa una LRR extra y sugiere una diferente curvatura y longitud de esta región. Se desconocen algunas de las implicaciones funcionales de las variaciones encontradas pero, considerando las diferencias existentes tanto en la distribución espacial de las LRR como en el número de los residuos de cisteínas, cabría suponer un plegamiento de las cadenas polipeptídicas de los FSHRs de peces distinto al descrito para humanos que potencialmente afectaría al modo de unión al ligando. A pesar de las diferencias estructurales mencionadas, la mayoría de los FSHRs de peces responden a las FSH de mamíferos (Levavi-Sivan et al., 2010; Zanuy et al., 2009). Respecto al LHR, no se dispone de la estructura cristalina pero se sabe que los aminoácidos implicados en la unión y especificidad del ligando de LHR de mamíferos están bien conservados en los LHR de peces (Rocha et al., 2007; Vischer y Bogerd, 2003).

El dominio transmembrana de los GTHRs es la parte más conservada y es la responsable de la activación del receptor y transducción de la señal. Por el contrario, el dominio intracelular muestra una alta variabilidad de secuencia entre los GTHRs de peces. Esta región contiene residuos involucrados en el acoplamiento a proteínas G, internalización del receptor y unión a diferentes moléculas de señalización intracelular (Ulloa-Aguirre et al., 2007).

\section{Especificidad}

Los GTHRs de mamíferos son altamente específicos con sus ligandos, mostrando menos de 0,1\% de actividad cruzada (Braun et al., 1991; Moyle et al., 1994), de manera que la actividad de cada GTH está dirigida solo a aquellas células que expresan su receptor. Sin embargo, en peces teleósteos la especificidad de los GTHRs parece ser menos evidente (Bogerd et al., 2005). A pesar de la conservación estructural entre los GTHRs de peces, algunos estudios in vitro han revelado reconocimientos promiscuos de FSH y LH dependiendo de la especie y el origen (homólogas o heterólogas) (Ko et al., 2007; Kwok et al., 2005; Oba et al., 1999a; Oba et al., 1999b; Rocha et al., 2007; Sambroni et al., 2007; So et al., 2005; Vischer et al., 2003).

\section{Transducción de la señal}

Según el modelo clásico de transducción de la señal de los GPCR, la activación del receptor conlleva la activación de proteínas $\mathrm{G}$ localizadas en la cara interna de la membrana plasmática que a su vez activan otras mo- 
léculas efectoras. La ruta de señalización intracelular mejor caracterizada y probablemente la más importante es la de la proteína quinasa A (PKA) mediada por AMP cíclico (AMPc). La activación de la proteína G estimula la adenilato ciclasa que cataliza la conversión de ATP a AMPc, el principal segundo mensajero de la acción de hormonas glicoproteicas (Zhang et al., 1991). El aumento de la concentración del AMPc intracelular libera la subunidad catalítica de la PKA permitiendo la fosforilación de numerosas proteínas celulares, entre ellas una clase de factores de transcripción que se unen a secuencias especificas conocidas como elementos de respuesta a AMPc (CREs). La fosforilación activa estos factores de trascripción y estos regulan la expresión de determinados genes, principalmente de enzimas implicados en la síntesis de esteroides. Además de la PKA se han identificado otras rutas de señalización que también son activadas por los GTHRs como las rutas MAPK, PKB, SGK o IP3/Ca2+/calmodulina/fosfatasa (Dias et al., 2010) cuyo significado fisiológico sigue bajo investigación.

\section{Gónadas}

Las gónadas son importantes órganos endocrinos destinados a producir gametos y especializados en la síntesis de esteroides sexuales. Estos esteroides juegan un papel esencial en los sistemas endocrinos de todos los vertebrados, con acciones que van desde la regulación del balance hídrico y mineral, la modulación de la respuesta inmunitaria, hasta la regulación de procesos implicados en la reproducción como la gametogénesis (Pankhurst, 2008).

\section{Esteroidogénesis}

Los esteroides sexuales, andrógenos, estrógenos y progestágenos, se sintetizan a partir del colesterol y su producción esta bajo el control de las GTHs. La esteroidogénesis ocurre en la mitocondria y en el retículo endoplasmático liso, donde una compleja cascada de enzimas oxidativos convierte el colesterol en diferentes tipos de esteroides. En particular, dentro de la mitocondria el colesterol es transformado en pregnenolona que es el precursor para la síntesis de todas las hormonas esteroideas (Fig. 8).

En líneas generales, durante las fases iniciales de la gametogénesis en machos, la FSH estimula la síntesis de andrógenos en las células de Leyding, principalmente de Testosterona (T) y 11-Ketotestosterona (11-KT), los cua- 
les regulan procesos de proliferación espermatogonial y espermiogénesis (Schulz et al., 2010). Posteriormente, durante la espermiación, se produce un cambio en la actividad esteroidogénica del testículo y la acción de la LH provoca un incremento en la síntesis de progestagenos o esteroides inductores de maduración (MIS), 17 $\alpha, 20 \beta$-dihidroxi-4-pregnen-3-ona (17,20 $\beta \mathrm{P})$ o $17 \alpha, 20 \beta, 21$-trihidroxi-4-pregnen-3-ona (20 $\beta S$ ), esenciales para la espermiación y la maduración de los espermatozoides (Fostier et al., 1983; Schulz et al., 2010). En hembras, la esteroidogénesis ovárica se desarrolla en la ma-

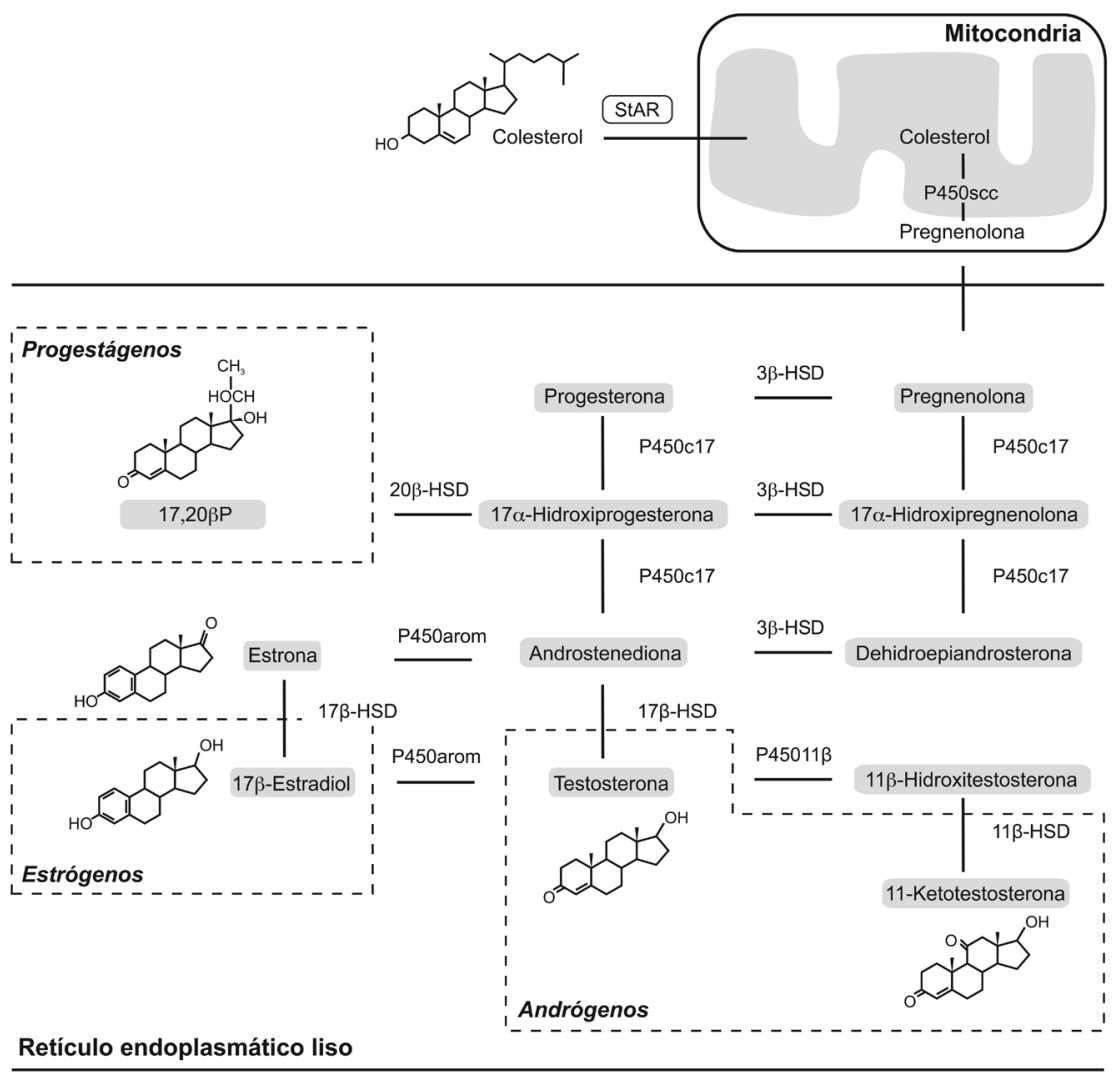

Figura 8. Ruta de biosíntesis de esteroides gonadales en peces teleósteos. Proteína reguladora de la respuesta esteroidogénica aguda (StAR); enzima P450 de la escisión de la cadena lateral de colesterol (P450scc); 17 $\alpha$-hidroxilasa/17,20-liasa (P450c17); 3 $\beta$-hidroxiesteroide deshidrogenasa $/ \Delta 5$ - $\Delta 4$-isomerasa ( $3 \beta$-HSD); $11 \beta$-hidroxiesteroide deshidrogenasa (11 $\beta$-HSD); $17 \beta$-hidroxiesteroide deshidrogenasa (17 $\beta$-HSD); $20 \beta$ - hidroxiesteroide deshidrogenasa (20 $\beta$-HSD); P450 aromatasa (P450arom); P450 11 $\beta$-hidroxilasa (P45011 $\beta) ; 17 \alpha, 20 \beta$-hidroxi-4pregnen-3-ona (17,20ßP). Las áreas con líneas discontinuas delimitan los esteroides predominantes en plasma de teleósteos. Modificado de Rocha (2008) 
yoría de especies según el modelo de dos células ("two-cell type model") propuesto por Nagahama (1994). En este modelo, las células foliculares de la teca sintetizan andrógenos precursores que son transportados a las células de la granulosa, donde son transformados en estrógenos o progestágenos. Durante la vitelogénesis, bajo el control principal de la FSH, las células de la teca sintetizan $\mathrm{T}$ que es convertida a E2 en las células de la granulosa mediante la enzima citocromo P-450 aromatasa (P-450arom), también conocida como CYP19A1 (Montserrat et al., 2004; Senthilkumaran et al., 2004). El E2 producido estimula la síntesis hepática de VTG que es transportada al ovario para ser incorporada a los oocitos en crecimiento (Nagahama, 1994). En la lubina, los niveles plasmáticos de T y E2 aumentan en paralelo conforme avanza el crecimiento oocitario y disminuyen durante la época de puesta, describiendo un perfil plasmático similar al de VTG (Asturiano et al., 2000; Asturiano et al., 2002; Prat et al., 1990). Una vez completada la vitelogénesis, antes de la maduración del oocito, la LH induce un giro en la actividad esteroidogénica del ovario. Se produce un cambio en la síntesis de esteroides precursores, de T a 17 $\alpha$-hidroxiprogesterona, y en la activación de enzimas esteroidogénicas, de P450arom (síntesis de E2) a 20 3 -HSD para la producción de MIS (17, 20 $\beta$ P o 20ßS) que regula la maduración del oocito (Nagahama y Yamashita, 2008). En especies de puesta múltiple como la lubina, se ha visto que después de cada oleada de progestágenos se produce un nuevo cambio en la esteroidogénesis gonadal provocando una nueva elevación de los niveles plasmáticos de T y E2. Este patrón se repite varias veces dependiendo del numero de ovulaciones en las hembra y espermiaciones en los machos (Asturiano et al., 2002) y responde a la presencia de grupos de gametos en diferente estados de desarrollo.

Como se menciono anteriormente, existe una comunicación permanente entre las diferentes partes del eje CHG. Este dialogo permite que la actividad de los diferentes componentes del eje este sincronizada a lo largo de la vida del animal, lo cual es crucial para coordinar adecuadamente las respuestas fisiológicas. Los esteroides sexuales son particularmente importantes ya que el cerebro y la hipófisis los usan como indicadores del estatus sexual. Modulan la actividad de los sistemas neuronales, afectando a la expresión de neuropéptidos y neurotransmisores, así como sus correspondientes receptores en el cerebro y la hipófisis, y la expresión hipofisaria de GTHs (Levavi-Sivan et al., 2010; Zohar et al., 2010). 


\section{Métodos de cuantificación de GTHs}

En las últimas décadas se han desarrollado diferentes tipos de ensayos para medir GTHs en diferentes especies de animales. En líneas generales, estos métodos se pueden agrupar en ensayos que estiman un número de moléculas o su masa mediante la unión específica a anticuerpos (inmunoensayos) y en ensayos que determinan una respuesta biológica de un sistema vivo ante la estimulación de FSH o LH (bioensayos in vitro).

\section{Inmunoensayos}

Los inmunoensayos están basados en la formación de complejos específicos antígeno-anticuerpo (Ag-Ac). Los primeros inmunoensayos que se desarrollaron para determinar GTHs, fueron radioinmunoensayos (RIA) basados en el uso de radioisótopos asociados a los complejos Ag-Ac. Aunque actualmente todavía siguen en uso, los RIAs se ha sustituido ampliamente por ensayos colorimétricos como los de inmunoabsorción ligados a enzimas, también conocidos como ELISAs. En líneas generales, tanto RIAs como ELISAs, se basan en la unión de las GTHs a anticuerpos específicos contra la subunidad FSH $\beta$ o LH $\beta$, estableciéndose una reacción competitiva de naturaleza físico-química entre moléculas (GTHs) marcadas, de concentración conocida y moléculas no marcadas de concentración desconocida.

Desde finales de los 80 se han desarrollado numerosos inmunoensayos homólogos para medir LH en diferentes especies de peces teleósteos, sin embargo para FSH únicamente se han puesto apunto en tres especies de salmónidos con desarrollo ovárico síncrono, salmón chum (Oncorhynchus keta), salmón coho (Oncorhynchus kisutch) y trucha arcoiris (Oncorhynchus mykiss), y en un perciforme con desarrollo ovárico asíncrono, tilapia (Oreochromis niloticus) (Tabla 5). Esta situación ha propiciado que existan muchos estudios sobre la actividad y función de la LH y menos sobre la de la FSH. Hecho que ha obstaculizado el esclarecimiento de las funciones de cada GTH en numerosas especies de peces. 


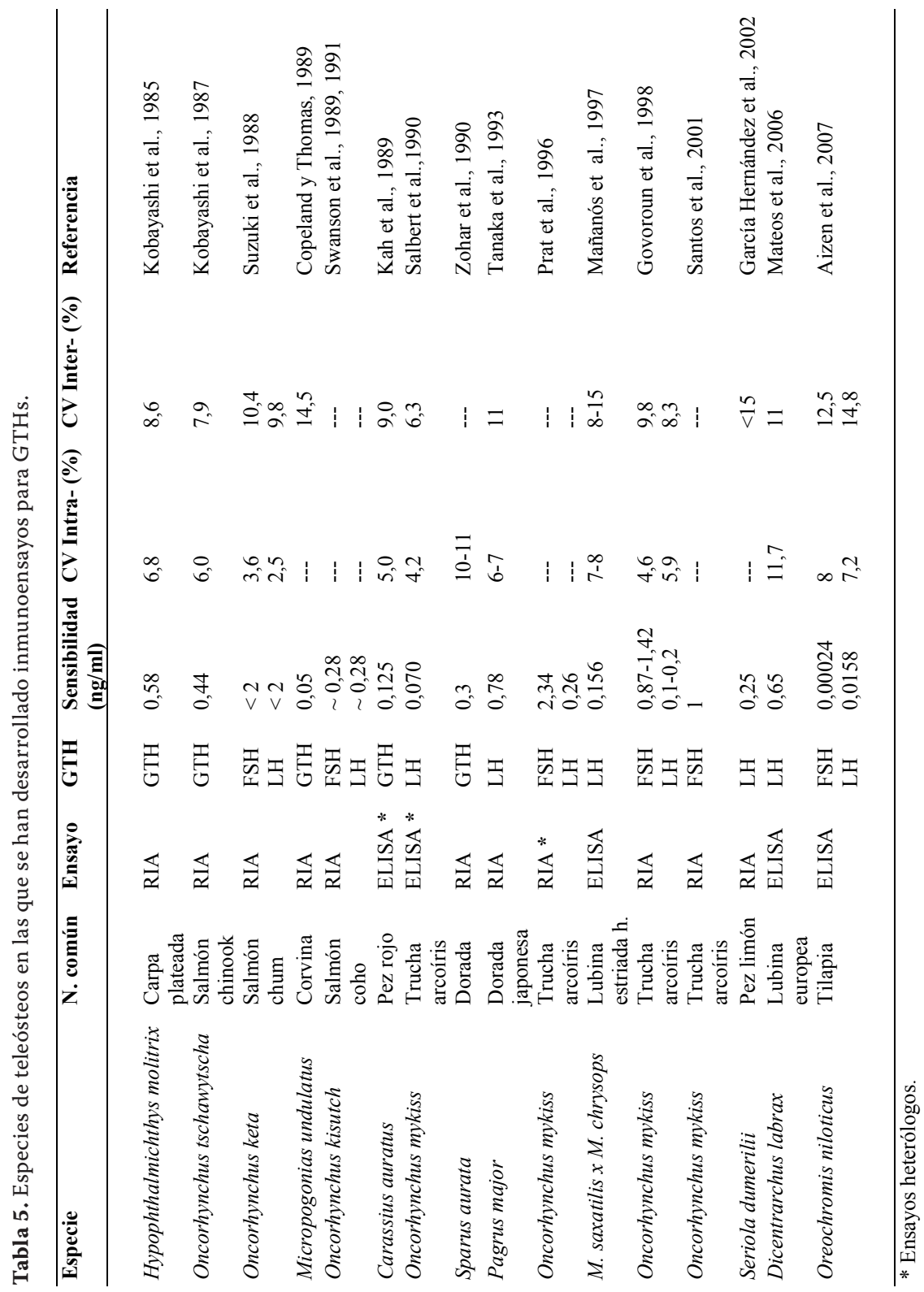




\section{Bioensayos}

Los bioensayos in vitro están basados, en respuestas celulares cuantificables a la estimulación con GTHs. Estas respuestas incluyen la producción de AMPc, producción de testosterona por cultivos de células de Leydig, actividad aromatasa o producción del activador de plasminógeno por cultivos de células de Sertoli o células de la granulosa.

Desde la clonación en los 90 de los ADNc de los FSHRs en rata y humanos, ha emergido una nueva generación de bioensayos basados en líneas celulares - como fibroblastos murinos (Ltk-), células embrionarias de riñón humano (HEK 293), células adrenales de ratón (Y-1) o de ovario de hámster chino $(\mathrm{CHO})$ - que expresan los genes de FSHR o LHR de la especie de in-

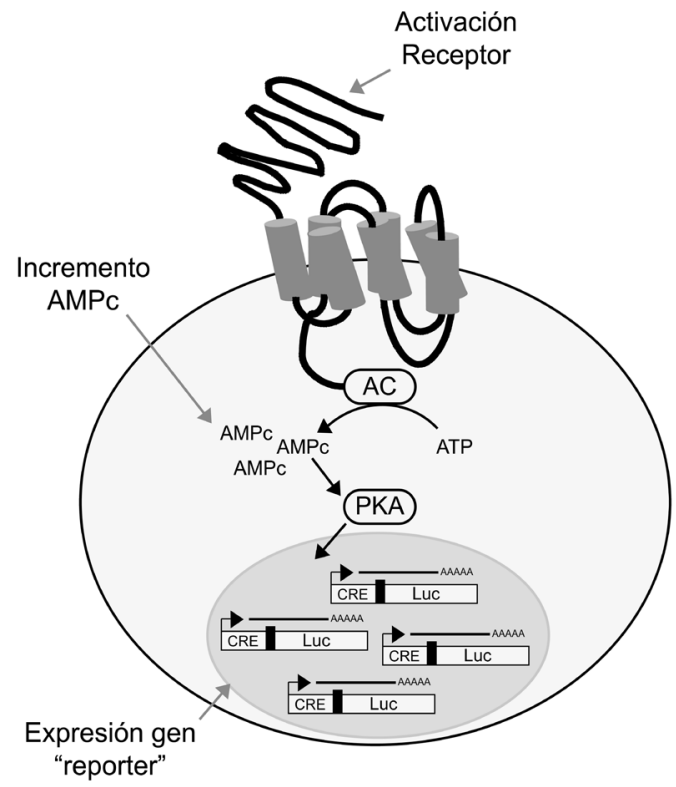

Figura 9. Representación esquemática de la activación de los GTHRs y su medición a través del uso de genes "reporter". Después de transfectar una línea celular con el receptor (FSHR o LHR) y un gen "reporter" como la luciferasa (Luc), la presencia y unión del ligando (FSH o LH) provoca la activación del receptor que estimula la adenilato ciclasa (AC) y cataliza la conversión de ATP a cAMP. El aumento intracelular del cAMP libera la subunidad catalítica de la proteína kinasa A (PKA) permitiendo la fosforilación de factores de transcripción que se unen a secuencias especificas conocidas como elementos de respuesta a cAMP (CRE) y regulan la expresión de determinados genes como el gen "reporter". 
terés como herramienta para medir las propias GTHs (Christin-Maitre et al., 2000). Como se vio anteriormente, los receptores de GTHs pertenecen a una familia de receptores acoplados a proteínas G. La unión de las GTHs a su respectivo receptor incrementa la actividad de la adenilato ciclasa y aumenta la producción de AMPc que se puede cuantificar directamente mediante radioinmunoensayos (RIAs) o indirectamente a través del uso de genes "reporter" que contienen en su promotor elementos de respuesta al AMPc (CRE) (Fig. 9). Estos bioensayos, desarrollados hasta el momento únicamente en mamíferos, han proporcionado métodos muy sensitivos de estimación de la actividad biológica de las GTHs presentes en diferentes muestras biológicas o en preparaciones puras de FSH y LH (Christin-Maitre et al., 2000; Rose et al., 2000) (Tabla 6).

Tabla 6. Especies en las que se han desarrollado bioensayos para GTHs.

\begin{tabular}{|c|c|c|c|c|c|c|c|}
\hline Especie & $\begin{array}{l}\text { Línea } \\
\text { celular }\end{array}$ & $\begin{array}{l}\text { Gen } \\
\text { "reporter" }\end{array}$ & GTHR & Sensibilidad & $\begin{array}{l}\text { CV } \\
\text { Intra- (\%) }\end{array}$ & $\begin{array}{l}\text { CV } \\
\text { Inter- (\%) }\end{array}$ & Referencia \\
\hline Homo Sapiens & HEK 293 & Luciferasa & FSHR & --- & --- & --- & Tilly et al., 1992 \\
\hline Homo Sapiens & Y-1 & --- & FSHR & --- & --- & --- & Kelton et al., 1992 \\
\hline Homo Sapiens & HEK 293 & Luciferasa & LHR & $0,3 \mathrm{ng} / \mathrm{ml}$ & 18 & 13 & Jia et al., 1993 \\
\hline Rattus norvegicus & Ltk $^{-}$ & --- & FSHR & $0,3 \mathrm{UI} / 1$ & 5,2 & 16,2 & $\begin{array}{l}\text { Gudermann et al., } \\
1994\end{array}$ \\
\hline Homo Sapiens & $\mathrm{CHO}$ & Luciferasa & FSHR & $\begin{array}{l}<3 \mathrm{UI} / 1 \\
(1,1 \mathrm{ng} / \mathrm{ml})\end{array}$ & --- & --- & $\begin{array}{l}\text { Albanese et al., } \\
1994\end{array}$ \\
\hline Homo Sapiens & $\mathrm{CHO}$ & --- & FSHR & $6,2 \mathrm{UI} / 1$ & 7,3 & 10,3 & Tano et al., 1995 \\
\hline Homo Sapiens & $\mathrm{CHO}$ & Luciferasa & FSHR & $<4 \mathrm{UI} / 1$ & 8 & 16 & $\begin{array}{l}\text { Cristin-Maitre et al., } \\
1996\end{array}$ \\
\hline Homo Sapiens & $\mathrm{CHO}$ & Luciferasa & FSHR & $0,010 \mathrm{UI} / 1$ & --- & --- & Kajitani et al., 2008 \\
\hline
\end{tabular}




Capítulo 2. OBJETIVOS 



\section{Objetivos}

La investigación desarrollada en la presente memoria de Tesis Doctoral se enmarca dentro del área de endocrinología reproductiva de peces. En las dos últimas décadas, en el Grupo de Fisiología de la Reproducción de Peces (GFRP) del Instituto de Acuicultura de Torre la Sal (IATS-CSIC), se ha venido realizando una gran actividad investigadora en relación con la reproducción de la lubina, un Perciforme de gran interés comercial en acuicultura. A pesar de los progresos alcanzados todavía existen algunos vacíos de conocimiento, sobre todo en lo que respecta a las funciones de las GTHs, y más concretamente de la FSH, durante la diferenciación sexual, pubertad y el ciclo reproductor.

En este contexto, el objetivo general de la presente Tesis Doctoral es contribuir al conocimiento de la función de las GTHs durante el proceso reproductor de la lubina. Para su consecución se plantearon cinco grandes objetivos que se abordaron usando diferentes metodologías:

1. Desarrollar herramientas moleculares para estudiar el perfil de expresión génica de GnRHs, GnRHR y GTHs durante la diferenciación sexual de la lubina y avanzar en el conocimiento del control endocrino de la misma.

- Desarrollo de PCRs semicuantitativos

- Análisis de los perfiles de expresión génica

2. Aislar y caracterizar bioquímica y funcionalmente la FSH nativa de lubina.

- Extracción alcohólica de glicoproteínas hipofisarias

- Cromatografía de intercambio iónico

- Cromatografía de fase reversa

- Secuenciación de proteínas

- Caracterización bioquímica por secuenciación de aminoácidos, espectrometría de masas, SDS-PAGE y western blot 
- Caracterización funcional en cultivos in vitro (líneas celulares y tejidos gonadales)

3. Desarrollar sistemas de producción de gonadotrofinas recombinantes de lubina que permitan disponer de los dímeros y las subunidades de FSH y LH de forma continuada.

- Puesta a punto de un sistema de expresión Baculovirus en células Sf9

- Puesta a punto de un sistema de expresión en células CHO

- Puesta a punto de un sistema de expresión en células de levadura

4. Caracterizar y comparar, bioquimica y funcionalmente, las diferentes GTHs recombinantes producidas (especificidad, biopotencia y vida media).

- Caracterización bioquímica por SDS-PAGE y western blot

- Activación especifica de receptores homólogos de GTHs

- Análisis de bioactividad en cultivos in vitro (líneas celulares y tejidos gonadales)

- Análisis de vida media en sangre (experimentos in vivo)

5. Desarrollar métodos para cuantificar FSH y estudiar su papel en el control endocrino de la diferenciación sexual y de la gametogénesis.

- Producción de anticuerpos policlonales mediante inmunización de conejos

- Desarrollo de un inmunoensayo homologo para FSH tipo "dot-blot"

- Desarrollo de un inmunoensayo homologo para FSH tipo "ELISA"

- Desarrollo de un bioensayo in vitro homologo para FSH usando el FSHR

- Estudio inmunohistoquímico de las GTHs en la hipófisis

- Análisis de los niveles de GnRHs y GTHs durante el proceso de diferenciación sexual

- Análisis de los niveles de FSH durante el proceso de gametogénesis

El desarrollo de estos objetivos ha dado lugar a resultados que han sido publicados en diferentes revistas científicas. La metodología empleada, los resultados obtenidos y la discusión de cada apartado se presentan en una 
compilación de las publicaciones originadas, capítulos 3-7. Finalmente, en el capitulo 8 se incluye una discusión general que aborda conjuntamente todos los resultados de esta Tesis Doctoral.

Nota: Las publicaciones mantienen los criterios de uniformidad de sus respectivas revistas, aunque se han editado para facilitar su lectura y adaptarlos al formato de la presente memoria de Tesis Doctoral. 



\section{Capítulo 3:}

Temporal profile of brain and pituitary GnRHs, GnRH-R and gonadotropin mRNA expression and content during early development in European sea bass (Dicentrarchus labrax L.)

Gregorio Molés, Manuel Carrillo, Evaristo Mañanós, Constantinos C.

Mylonas, Silvia Zanuy

General and Comparative Endocrinology 150, 75-86 (2007) 



\begin{abstract}
A likely endocrine control mechanism for sexual differentiation in sizegraded populations of European sea bass (Dicentrarchus labrax) is proposed by evaluating the brain expression and pituitary content of two forms of gonadotropin-releasing hormone $(\mathrm{GnRH})$, namely sea bream (sbGnRH) and salmon (sGnRH), the pituitary expression of one subtype of $\mathrm{GnRH}$ receptor (dlGnRH-R-2A) and the three gonadotropin (GtH) subunits, namely glycoprotein $\alpha(\mathrm{GP} \alpha)$, follicle-stimulating hormone $\beta(\mathrm{FSH} \beta)$ and luteinizing hormone $\beta$ (LH $\beta)$, as well as the pituitary and plasma LH levels between 50 and 300 days post-hatching (dph). Four gradings were conducted between 2 and 8 months after hatching, resulting in a population of large and small individuals, having $96.5 \%$ females (female-dominant population) and $69.2 \%$ males (male-dominant population), respectively, after the last grading. The onset of gonadal differentiation was different in the two sexes, and coincided with a peak of expression of sbGnRH or sGnRH. Furthermore, the expression of these GnRHs was correlated with the expression of dlGnRH-R-2A. Sexrelated differences in the brain and pituitary content of sbGnRH were also found at the time of sexual differentiation. Moreover, the observed sexual dimorphism at the transcriptional or synthesis level of these GnRH forms suggests that a different neuro-hormonal regulation is operating according to sex. At the onset of sex differentiation, $\mathrm{FSH} \beta$ transcriptional activity reached maximal values, which were maintained until the completion of the process. The present study suggests a role for sbGnRH, sGnRH and the dlGnRH-R-2A during gonadal differentiation, possibly through enhancement of FSH $\beta$ gene expression. In males, a different endocrine regulation seems to exist also during spermiogenesis and spermiation, when gene transcription, peptide synthesis and release of $\mathrm{LH}$ are of greater importance.
\end{abstract}

Keywords: GnRHs, GnRH receptor, gonadotropins, sex differentiation, European sea bass 


\section{Introduction}

The study of sex differentiation in fish represents a unique opportunity to understand the plasticity of this process, considering the high diversity and the wide range of aquatic habitats. Since the pioneer publication of Yamamoto (1969), excellent reviews on sex differentiation in fish have demonstrated its importance and interest (Baroiller et al., 1999; Devlin and Nagahama, 2002; Nakamura et al., 1998). The endocrine control of sex differentiation in fish requires a complex interplay between the brain, pituitary and gonads through the production of brain neuropeptides and neurotransmitters, pituitary-derived gonadotropins $(\mathrm{GtH})$ and steroids produced in the gonad and brain. Moreover, a strong interaction with some still weakly defined environmental factors also contributes to activate the brain-pituitary-gonadal axis to trigger the process of sex differentiation in fish. This extraordinary complexity has been an important barrier that restricted such studies to only few species of teleosts, where only partial aspects of the molecular and endocrine regulation of sex differentiation have been examined (Devlin and Nagahama, 2002; Nagahama, 1999). In teleosts, the activation of the brain-pituitary axis may be a key event in the onset of sex differentiation (Baroiller et al., 1999), but what leads to the activation of this axis is not yet well understood.

The European sea bass (Dicentrarchus labrax) is a highly valuable fish for European aquaculture. Due to the fact that females grow faster than males and reach marketable size before maturing, it is desirable to produce female monosex populations. As a result, this species has been the object of various studies on the environmental, genetic and hormonal control of sex differentiation (reviewed by Carrillo et al. (1999) and Piferrer et al. (2005)). In European sea bass, as in other perciform fishes, three different $\mathrm{GnRH}$ forms are expressed in the brain: sea bream GnRH (sbGnRH) is expressed mainly in the preoptic area (POA) cells, salmon GnRH (sGnRH) mostly in the olfactory bulbs and chicken GnRH-II (cGnRH-II) in the midbrain tegmentum with apparently diverse functions, but not playing a direct role in regulating the pituitary-gonadal axis (González-Martínez et al., 2002a,b). These GnRH systems are already developed by the time the genital crest starts to be evident in this species (González-Martínez et al., 2004), indicating that this machinery is totally formed, well before sex differentiation occurs. It has been stated that in European sea bass, sbGnRH represents 
the main hypophysiotrophic hormone (González-Martínez et al., 2002a,b; González-Martínez et al., 2001; Rodríguez et al., 2000). A direct effect on the gonadotropic cells to regulate $\mathrm{GtH}$ secretion has been ascribed to sGnRH (González-Martínez et al., 2002b) because sGnRH innervation has been observed in European sea bass pituitary, although it is considerably less than sbGnRH. Nevertheless, both forms peaked at the time of sex differentiation in a population of European sea bass of a mixed and unidentified sex (Rodríguez et al., 2000). However, no specific information is available from populations of fish in which sex is known or could be anticipated with a certain degree of confidence. In the European sea bass, two subtypes of GnRH receptors (GnRH-R) were described (González-Martínez et al., 2004; Lethimonier et al., 2004), whereas recently five GnRH-R subtypes, encoded by five different genes, have been isolated in fish (Moncaut et al., 2005). From these five subtypes, dlGnRH-R-2A is highly expressed in the pituitary LH cells, but also in some FSH cells, and its expression increases as the European sea bass matures sexually (González-Martínez et al., 2004), indicating its importance in reproductive events. Nevertheless, the role of dlGnRH-R2A during sex differentiation remains to be explored.

Gonadotropin-releasing hormone acts on the pituitary gland to stimulate the synthesis and secretion of GtHs. Today, the existence of two GtHs in the pituitary gland [luteinizing hormone (LH) and follicle-stimulating hormone (FSH)] with distinct patterns of expression at different stages of the reproductive cycle has been confirmed in various teleosts, including the European sea bass (reviewed in Yaron et al., 2001, 2003; Mateos et al., 2003). Gonadotropins have been shown to play a critical role in sex differentiation both in gonochoristic and hermaphroditic fishes (reviewed in Devlin and Nagahama, 2002). Most physiological studies have been conducted mainly on LH, while the function of FSH has not been fully addressed, because FSH immunoassays for non-salmonid fishes are not available. Nevertheless, it has been claimed that FSH regulates gametogenesis, since it promotes the production of $17 \beta$ estradiol (E2) and the incorporation of vitellogenin into the oocytes (Planas et al., 2000; Swanson, 1991). In addition, it appears to stimulate Sertoli cell proliferation and maintenance of quantitatively normal spermatogenesis mediated by these cells (Bogerd et al., 2005). On the other hand, LH is known to stimulate gonadal steroidogenesis in testicular Leydig cells and is involved in oocyte maturation and ovulation, and in spermiation (Prat et al., 1996; Schulz and Miura, 2002). In male European 
sea bass, FSH mRNA levels increase continuously with gonadal growth suggesting an important role in the maintenance of spermatogenesis, while LH synthesis and release is maximum during late gametogenesis and spawning (Mateos et al., 2003). Moreover, in European sea bass, LH was more involved with later stages of gonadal development than with sex differentiation (Rodríguez et al., 2000).

It has been shown recently that in European sea bass, there is a relation between growth and phenotypic sex differentiation early in development, i.e. large fish usually differentiate into females and small ones into males (Papadaki et al., 2005). Taking advantage of a male-dominant and a femaledominant population created in the latter study, the objective of the present study was to investigate the possible endocrine control mechanisms of sexual differentiation in European sea bass by evaluating the brain expression and pituitary content of sbGnRH and sGnRH, which are the two hypophysotopic forms of $\mathrm{GnRH}$; the pituitary expression of the gonadotropin-releasing hormone receptor (dlGnRH-R-2A) and the expression of the three GtH subunits, which are glycoprotein alpha subunit $(\mathrm{GP} \alpha), \mathrm{FSH} \beta, \mathrm{LH} \beta$, as well as the pituitary and plasma LH levels throughout the period of sexual differentiation of male- and female-dominant populations.

\section{Materials and methods}

\subsection{Fish husbandry and production of female- and male-dominant stocks: fish sampling}

The populations used in the present study were those developed by size grading in the study of Papadaki et al. (2005). In brief, hatched larvae and fry obtained from a natural spawning (February 2001) were reared at the Hellenic Centre for Marine Research, Institute of Aquaculture (Crete, Greece), using the "mesocosm" method (Divanach and Kentouri, 2000). Four gradings were conducted between 2 and 8 months after hatching, separating the fish to large and small individuals, approximately in a 50:50 ratio. The first grading was performed at $66 \mathrm{dph}$ using a $3.5-\mathrm{mm}$ bar grader, separating the population to large (L) and small (S) fish. The second grading was done at $123 \mathrm{dph}$ for the $\mathrm{S}$ population (6-mm bar grader), separating the fish again to small (SS) and large (SL). The SL fish were discarded. At $143 \mathrm{dph}$, the L population was similarly graded (8-mm bar grader), but instead the 
LL fish were kept and the LS were discarded. Following the same principle, the third grading was performed on 166 and $167 \mathrm{dph}$ for the SS and the LL populations, respectively, and the fourth grading on 222 and $223 \mathrm{dph}$, for the SSS and LLL populations, respectively. In this way, the L-extreme and S-extreme populations were created, by discarding about $50 \%$ of the population at each grading. Examination of gonadal histology of fish from these populations revealed that phenotypic sex could not be determined prior the second grading (123-143 dph), and therefore it is not known what effect the first grading had on the sex ratio of the two populations. After the second grading, the female percentage was already $91 \%$ in the L-extreme population, but the male percentage in the S-extreme population was only $50 \%$. With each subsequent grading, the percentage of females in the L-extreme population increased slightly (5\%), while that of males in the S-extreme population had a larger increase (20\%). At $300 \mathrm{dph}$, the S- and L-extreme populations consisted of $69.2 \%$ males (male-dominant) and $96.5 \%$ females (female-dominant), respectively (Papadaki et al., 2005). In the present study, fish were sampled every 50 days between 50 and $300 \mathrm{dph}$. At $50 \mathrm{dph}$, samples were taken before the grading procedure started. At 100, 150 and 200 $\mathrm{dph}$, the sex proportion of the two populations was different (Papadaki et al., 2005), but the sex of the individual fish sampled for tissues could not be macroscopically identified. On the 250 and $300 \mathrm{dph}$ sampling, however, the sex of each sampled fish was identified after sacrifice by a tissue squash examined under a microscope, and only females were included in the femaledominant group and only males in the male-dominant one.

Samples of brains and pituitaries of fish from the male- and female-dominant populations ( $\mathrm{S}$ - and L-extreme populations, respectively) were collected every 50 days between 50 and $300 \mathrm{dph}$, whereas blood was collected from 150 to $300 \mathrm{dph}$. Dissection of the brain and pituitary was not possible between 50 and $100 \mathrm{dph}$ due to the small size of the fish; therefore, whole fish heads were collected at these times. Brain and pituitaries (or the whole head when available) were deep frozen immediately in liquid nitrogen and kept at $-80^{\circ} \mathrm{C}$ until analysis. From $150 \mathrm{dph}$ onwards, blood samples were taken from the caudal vasculature using heparinized syringes and centrifuged at $4{ }^{\circ} \mathrm{C}, 6000 \mathrm{rpm}$ for $15 \mathrm{~min}$. The separated plasma was aliquoted and kept at $-80^{\circ} \mathrm{C}$ until analysis.

Handling of the fish was done according to the European Union Directive (EEC, 1986) for the protection of animals used for experimental and other 
scientific purposes.

\subsection{Development of a semiquantitative polymerase chain reaction technique for GnRHs, GtHs and GnRH-R}

Semiquantitative polymerase chain reactions (PCRs) were set up to analyze the relative amounts of mRNA for several genes, including the GnRHs (sbGnRH and sGnRH), the D. labrax GnRH receptor 2A (dlGnRH-R-2A) and the GtH subunits (GP $\alpha, F S H \beta$ and $L H \beta)$ in brain and pituitary. PCR amplification of ribosomal $18 \mathrm{~S}$ was used as a reference for RNA quantity and reverse transcription efficiency, based on the limited variation of $18 \mathrm{~S}$ expression with the time and stage of the animals. The full-length cDNAs for all these genes were previously cloned (Mateos et al., 2003; Zmora et al., 2002), which allowed us to design the corresponding specific primers for use in PCR (Table 1). To develop the semiquantitative PCR technique, we tested diVerent ranges of $\mathrm{MgCl} 2(0.75,1.5$ and $3 \mathrm{mM})$ and annealing temperatures $\left(56-58^{\circ} \mathrm{C}\right)$ for each set of primers. Once the concentration of the reagents and the optimal annealing temperatures were standardized, a test of cycles (from 12 to 40 cycles) for each gene was performed for several initial concentrations of template $(0.2,0.4,0.8$ and $1.6 \mu \mathrm{l}$ of cDNA). The optimal number of cycles, which gave an intensity located in the midpoint of the growing phase, was chosen for each gene in order to determine its relative abundance (Table 1). Briefly, total RNA was extracted of individual brains and pituitaries with the Trireagent (Molecular Research Centre, Inc., Cincinnati, OH, USA) and treated with RQ1 DNase (Promega Corp.). Total RNA (1-4 $\mu \mathrm{g})$ was reverse-transcribed to cDNA in a $20-\mu$ l reaction volume using random primers (hexamers, $50 \mathrm{ng}$ ) and SuperScript II (200 units) reverse transcriptase (Invitrogen). The PCR amplifications were performed with a thermal cycling, Gene Amp PCR System 2700 (Applied Biosystems), and all were performed with $1 \mu \mathrm{l}$ of cDNA, $0.5 \mu \mathrm{M}$ of each specific primer, $0.2 \mathrm{mM}$ dNTPs and $1.5-3 \mathrm{mM} \mathrm{MgCl} 2$ in a $20-\mu \mathrm{l}$ of reaction volume. Thermal cycling parameters were: denaturation step of $94^{\circ} \mathrm{C}$ for $30 \mathrm{~s}$, annealing step of $57^{\circ} \mathrm{C}$ for $45 \mathrm{~s}$ and elongation step of $72^{\circ} \mathrm{C}$ for $45 \mathrm{~s}$. PCR that contained water in place of cDNA template served as negative controls. At the end, PCR samples were run on $1 \%$ agarose gels, containing ethidium bromide and the intensity of the bands analyzed on a densitometer, under UV light. The data were normalized to the transcript abundance of ribosomal 18S; 
Table 1. Primers and conditions used in a semiquantitative PCR technique for the GnRHs, the dlGnRH-R-2A and the GtH subunits gene expression analysis.

\begin{tabular}{|c|c|c|c|c|}
\hline Primer & Sequence (5'-3') & Amplicon size (bp) & $\mathrm{Mg}^{2+}(\mathrm{mM})$ & Cycles \\
\hline \multirow[t]{2}{*}{ GP- $\alpha$} & F: TGGACTTATCAAACATGGG & 245 & 3 & 24 \\
\hline & R: GTGGCAGTCTGTGTGGTTTC & & & \\
\hline \multirow[t]{2}{*}{ FSH- $\beta$} & F: GTCATCCCACCAACATCAG & 275 & 3 & 28 \\
\hline & R: TATGTCTCCAGGAAAGCG & & & \\
\hline \multirow[t]{2}{*}{ LH- $\beta$} & F: GCTCATCAACCAGACAGTG & 286 & 3 & 38 \\
\hline & R: CAGGCTCTCGAAGGTACAG & & & \\
\hline \multirow[t]{2}{*}{ sbGnRH } & F: GAGAGAGAAGAATGGCTG & 294 & 1.5 & 36 \\
\hline & R: GATTTCCGTTCTCCCTGTGAGTG & & & \\
\hline sGnRH & $\begin{array}{l}\text { F: GTTGTTGGCGTTGGTGG } \\
\text { R: CGGTCAAAATGACTGGAATC }\end{array}$ & 214 & 1.5 & 34 \\
\hline cGnRH-II & $\begin{array}{l}\text { F: CTGTTTGGGCTGCTTCTATGTGT } \\
\text { R: TCACTTCCTCTTCTGGAGCTC }\end{array}$ & 234 & 1.5 & 38 \\
\hline GnRH-R & $\begin{array}{l}\text { F: GAATATCACAGTCCAGTGG } \\
\text { R: CCAGCAGACGATGAAAGAC }\end{array}$ & 535 & 1.5 & 36 \\
\hline $18 \mathrm{~S}$ & $\begin{array}{l}\text { F: TCAAGAACGAAAGTCGGAGG } \\
\text { R: GGACATCTAAGGGCATCACA }\end{array}$ & 485 & 3 & 18 \\
\hline
\end{tabular}

thus, the results were expressed as the ratio between the optical density of the specific gene and that of $18 \mathrm{~S}$.

\subsection{GnRH forms immunoassays}

Phenolic phases from the RNA extraction of 8-10 individual heads or brains or pituitaries, per sampling point, were extracted for $10 \mathrm{~min}$ at $80^{\circ} \mathrm{C}$ by adding $150 \mu \mathrm{l}$ of $2 \mathrm{~N}$ acetic acid, centrifuged $\left(4^{\circ} \mathrm{C}\right.$ for $30 \mathrm{~min}$ at $\left.10,000 \mathrm{~g}\right)$ and supernatants collected, air-dried and reconstituted in assay buffer for analysis. Levels of sbGnRH and sGnRH were measured simultaneously in each reconstituted sample using competitive enzyme-linked immunosorbent assays (EIA), specific for each GnRH form. The sGnRH was determined using an EIA developed for European sea bass (Kah et al., 1994). The EIA for sbGnRH was performed according to Holland et al. (1998). The sGnRH EIA had a sensitivity of $2 \mathrm{pg} /$ well and a cross-reactivity with sbGnRH of $0.005 \%$. The sbGnRH assay had a sensitivity of $6 \mathrm{pg} /$ well and a cross-reactivity with sGnRH of 0.4\% (Holland et al., 1998). Protein levels were measured according to Bradford (1976).

\subsection{LH immunoassay}

Measurement of LH was carried out in pituitaries and plasma of 10-12 fish, per sampling point, by a homologous ELISA (Mateos et al., 2006) based 
on the method described for the striped bass Morone saxatilis (Mañanós et al., 1997). The European sea bass LH EIA uses specific polyclonal antibodies against the European sea bass LH $\beta$ subunit and European sea bass LH for the standard curve. The sensitivity of the assay was $0.65 \mathrm{ng} / \mathrm{ml}$ and intraand inter-assay coefficients of variation of $11.7 \%(n=8)$ and $11 \%(n=10)$, respectively.

\subsection{Data analysis}

Differences between the female- and male-dominant populations throughout the experiment, in mRNA expression levels of GnRHs, dlGnRH-R-2A and GtH subunits; brain and pituitary content of the GnRHs; and pituitary and plasma levels of LH were examined using two-way ANOVA, with sex (male- and female-dominant population) and sample time as fixed factors, followed by the Holm-Sidak test. When necessary, normality was ensured using the Kolmogorov-Smirnoff test after logarithmic transformation of data. Barlett's test was used to establish homogeneity of variances. A linear correlation test was also conducted on the relationship between gene expression and brain and pituitary levels of the sbGnRH and sGnRH, dlGnRH-R-2A receptor and the three GtH subunits and pituitary and plasma levels of LH. A Pearson product-moment correlation coefficient was calculated. Statistical analyses were done with a statistical software (Sigmastat v.3.0 SPSS). The level of $P$ at which the results were deemed significance was $\mathrm{P}<0.05$. Results are reported as means \pm S.E.M.

\section{Results}

\subsection{Brain sGnRH and sbGnRH gene expression}

Brain mRNA levels for sbGnRH and sGnRH showed significant differences, both over time and between male and female-dominant populations. A significant and steady increase in expression of sbGnRH was observed in the male-dominant population from $50 \mathrm{dph}$ onwards, peaking at $200 \mathrm{dph}$ and decreasing thereafter (Fig. 1A). The pattern of sbGnRH gene expression in the female-dominant population was bimodal, peaking both at 150 and $250 \mathrm{dph}$ (Fig. 1B). At $300 \mathrm{dph}$, the expression of sbGnRH in the female population was significantly higher $(\mathrm{P} \leq 0.05)$ than in the male one. At 50 
and $100 \mathrm{dph}$, values of sGnRH expression were very low in both populations, with a significant $(\mathrm{P} \leq 0.001)$ increase occurring at $150 \mathrm{dph}$ (Figs. $1 \mathrm{C}$ and $\mathrm{D})$. However, in the male-dominant population, the transcript values of sGnRH continuously increased in the following period until reaching maximum levels at $200 \mathrm{dph}$ (Fig. 1C), whereas in the female-dominant population there were two peaks at 150 and $250 \mathrm{dph}$ (Fig. 1D). Salmon GnRH gene expression in the male-dominant population was significantly higher than in the female-dominant population, both at 100 and $200 \mathrm{dph}(\mathrm{P} \leq 0.05$ and $\mathrm{P} \leq 0.001$, respectively). A regression correlation between the expression of sbGnRH and sGnRH in the two populations yielded a coefficient of correlation $(r)$ of $0.942(\mathrm{P} \leq 0.01)$ for the male and $0.960(\mathrm{P} \leq 0.01)$ for the femaledominant populations, respectively (Table 2 ).

\subsection{Gene expression of dIGnRH-R-2A in the pituitary}

At $50 \mathrm{dph}$, pituitary dlGnRH-R-2A mRNA in the male-dominant population was very low, increased progressively until $150 \mathrm{dph}$, and a high and significant $(\mathrm{P} \leq 0.001)$ surge was observed at $200 \mathrm{dph}$ (Fig. 1E). Thereafter, high levels of expression were maintained until the end of the surveyed period at $300 \mathrm{dph}$. In the female-dominant population, pituitary dlGnRH-R$2 \mathrm{~A}$ gene expression was low at $50 \mathrm{dph}$. A steady increase was observed from that time on to peak at $250 \mathrm{dph}$, while a significant decrease $(\mathrm{P} \leq 0.001)$ was observed at $300 \mathrm{dph}$ (Fig. 1F). The relationship between the profiles of expression of pituitary dlGnRH-R-2A and brain sbGnRH and sGnRH was evaluated through a regression line analysis both in the male- $(\mathrm{r}=0.816, \mathrm{P} \leq$ 0.05 and $\mathrm{r}=0.909, \mathrm{P} \leq 0.05$, respectively) and female-dominant populations $(\mathrm{r}=0.809, \mathrm{P} \leq 0.05$ and $\mathrm{r}=0.697, \mathrm{P} \leq 0.1$, respectively) (Table 2).

\subsection{Brain levels of sbGnRH and sGnRH}

At 50 and $100 \mathrm{dph}$, the whole-head content of sbGnRH was very low both in the female- and in the male-dominant populations (data not shown). In the male-dominant population, brain content of sbGnRH was low at 150 and $200 \mathrm{dph}$, increasing significantly $(\mathrm{P} \leq 0.001)$ at $250 \mathrm{dph}$ and decreasing $(\mathrm{P} \leq 0.05)$ in the following sampling time (Fig. 2A). At $150 \mathrm{dph}$, brain sbGn$\mathrm{RH}$ content in the female-dominant population was also low, but increased steadily thereafter and peaked at $250 \mathrm{dph}$ (Fig. 2B). The sbGnRH brain con- 

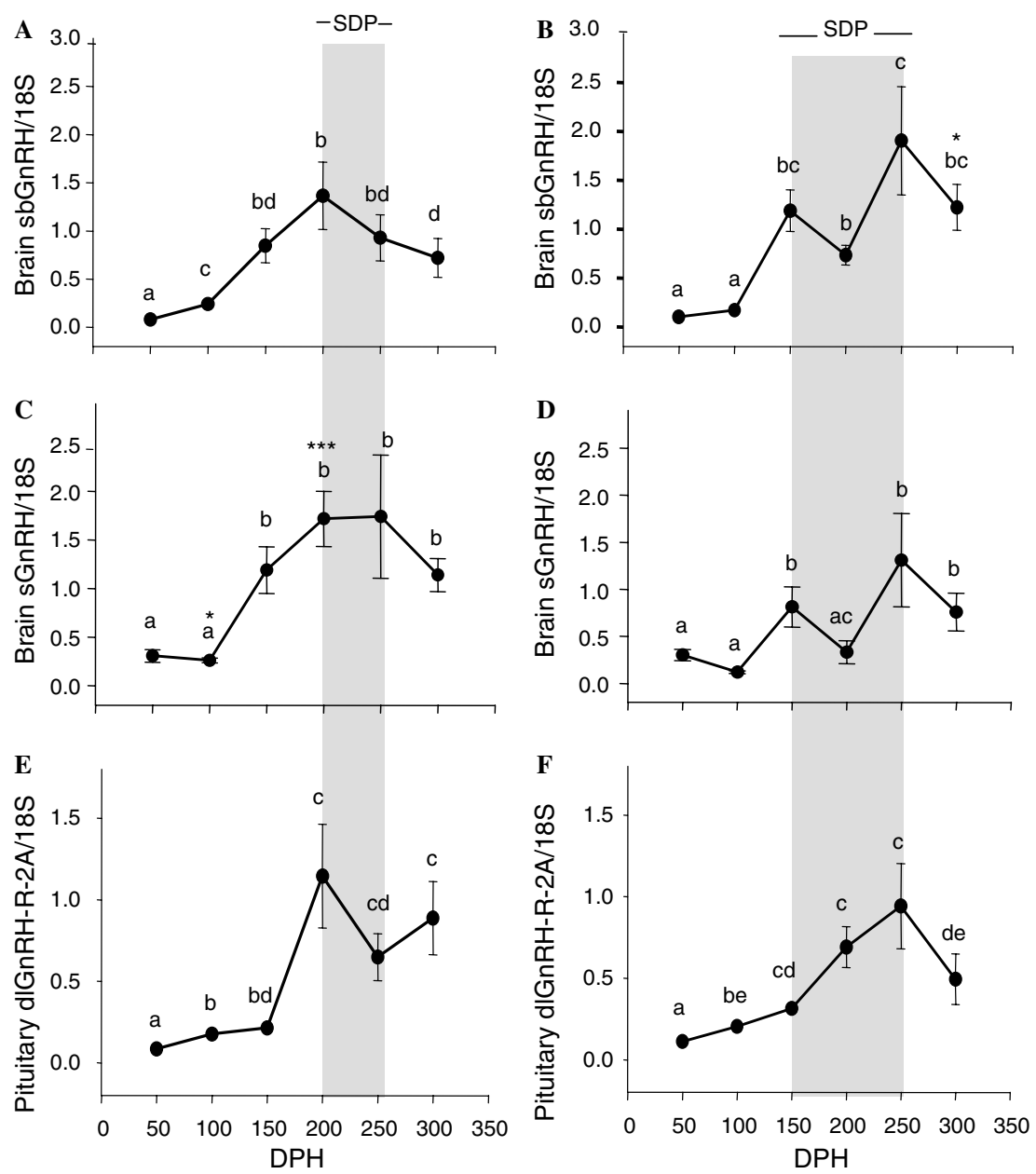

Figure 1. Temporal variations of the levels of the brain sbGnRH mRNA (A and B) and sGnRH mRNA ( $C$ and D) and of the pituitary dlGnRH-R-2A mRNA (E and F) in male- and femaledominant populations of European sea bass during the first year of life. Different letters indicate significant differences over the time for female or male populations. Asterisks indicate significant (*P $\leq 0.05 ; * * \mathrm{P} \leq 0.001)$ differences between two populations at equivalent dates. Sex differentiation period (SDP) are depicted as a shaded bar in the figure.

tent of the female-dominant population was significantly higher than that of the male-dominant population only at 150 and $200 \mathrm{dph}(\mathrm{P} \leq 0.05$ and $\mathrm{P} \leq$ 0.01 , respectively). Similarly, the whole-head content of sGnRH was very low at 50 and $100 \mathrm{dph}$ in both populations (data not shown). A steady increase 
was detected from $150 \mathrm{dph}$ onwards, peaking at $250 \mathrm{dph}$ in both populations (Figs. 2C and D).

\subsection{Pituitary levels of sbGnRH and sGnRH}

High levels of sbGnRH pituitary content were found in the male-dominant population at $150 \mathrm{dph}$ (Fig. 2A). A significant decrease ( $\mathrm{P} \leq 0.001)$ was observed at $200 \mathrm{dph}$, which was maintained almost constant until the end of the study. Similarly, the sbGnRH pituitary content of the female-

$\mathbf{A}$
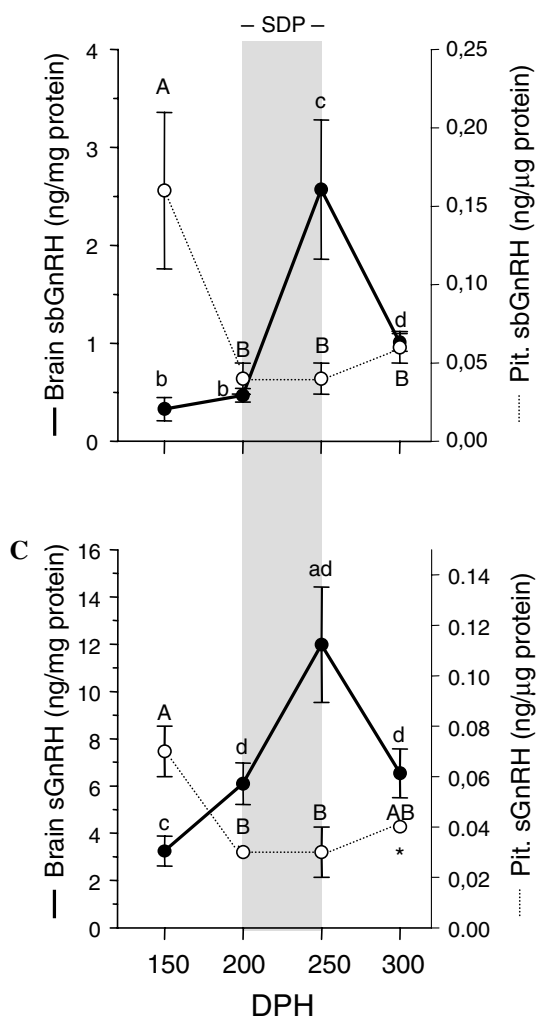

B $\quad$ Female population
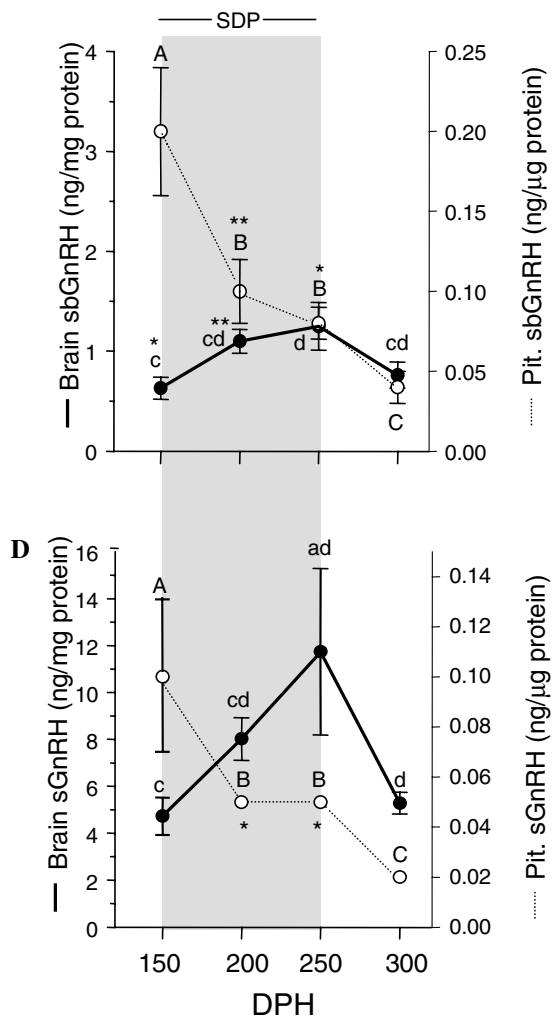

Figure 2. Temporal profiles of brain (-) and pituitary (....) content of sbGnRH (A and B) and sGnRH (C and D) in male- and female-dominant populations of European sea bass during the first year of life. Different lower case and upper case letters indicate significant differences over the time for brain or pituitary GnRH levels, respectively. Asterisks indicate significant $(" \mathrm{P} \leq 0.05$; " $\mathrm{P} \leq 0.01)$ differences between two populations at equivalent dates. Rest of the legends refer to Fig. 1. 
dominant population was highest at $150 \mathrm{dph}$ and decreased significantly (P $\leq 0.05$ ) thereafter. In addition, at 200 and $250 \mathrm{dph}$, the pituitary sbGnRH levels of female-dominant population were significantly higher than in the male-dominant population ( $\mathrm{P} \leq 0.01$ and $\mathrm{P} \leq 0.05$ and Figs. $2 \mathrm{~B}$ and $\mathrm{A}$, respectively). In both populations, the profile of pituitary sGnRH content was very similar to that of sbGnRH in which it exhibited the same significant differences within and between populations (Figs. $2 \mathrm{C}$ and D). The only difference was that values at the starting time $(150 \mathrm{dph})$ were about half those of sbGnRH.

\subsection{Gene expression of the GtH subunits in the pituitary}

Expression of GP $\alpha, \mathrm{FSH} \beta$ and $\mathrm{LH} \beta$ was almost undetectable at 50 and $100 \mathrm{dph}$ in both populations (Figs. 3A-D and 4A and B, respectively). In the male-dominant population, the first significant rise $(\mathrm{P} \leq 0.001)$ of $\mathrm{GP} \alpha$ subunit mRNA occurred at $150 \mathrm{dph}$, peaked further at $200 \mathrm{dph}$ and high levels of expression were maintained thereafter until the completion of the experiment (Fig. 3A). In the female-dominant population, the first significant increase of expression occurred at $150 \mathrm{dph}$, with high levels at $200 \mathrm{dph}$, which remained constant thereafter (Fig. 3B). The level of GP $\alpha$ gene expression in the male population was significantly higher $(\mathrm{P} \leq 0.01)$ than that of

Table 2. Linear regression tests on the relationship between brain and pituitary gene expression levels of sbGnRH and sGnRH, dlGnRH-R-2A and the three GtH subunits (GP $\alpha, F S H \beta$ and $\mathrm{LH} \beta$ ) and pituitary and plasma levels of $\mathrm{LH}$.

\begin{tabular}{|c|c|c|c|c|c|c|}
\hline & \multicolumn{3}{|l|}{ Male population } & \multicolumn{3}{|l|}{ Female population } \\
\hline & ${ }^{\mathrm{a}} \mathrm{RL}$ & ${ }^{b} r$ & $\mathrm{P} \leq$ & ${ }^{\mathrm{a}} \mathrm{RL}$ & ${ }^{b}$ & $\mathrm{P} \leq$ \\
\hline \multicolumn{7}{|c|}{ Gene expression/gene expression } \\
\hline sbGnRH vs sGnRH & $Y=-0.0244+0.682 X$ & 0.942 & 0.01 & $Y=0.0305+1.514 X$ & 0.960 & 0.01 \\
\hline dlGnRH-R-2A vs sbGnRH & $Y=0.00158+0.751 X$ & 0.816 & 0.05 & $Y=0.134+0.368 X$ & 0.809 & 0.05 \\
\hline dlGnRH-R-2A vs sGnRH & $Y=-0.00188+0.447 X$ & 0.909 & 0.05 & $Y=0.158+0.499 X$ & 0.696 & 0.1 \\
\hline $\mathrm{LH} \beta$ vs GP $\alpha$ & $Y=-0.268+1.352 X$ & 0.975 & 0.05 & $Y=0.161+2.064 X$ & 0.972 & 0.05 \\
\hline FSH $\beta$ vs GP $\alpha$ & $Y=0.609+1.058 X$ & 0.990 & 0.01 & $Y=0.188+0.427 X$ & 0.977 & 0.05 \\
\hline dlGnRH-R-2A vs GP $\alpha$ & $Y=0.0757+0.935 X$ & 0.959 & 0.01 & $Y=0.1320+0.866 X$ & 0.873 & 0.05 \\
\hline dlGnRH-R-2A vs FSH $\beta$ & $Y=0.0892+0.5 X$ & 0.932 & 0.001 & $Y=0.1240+0.536 X$ & 0.843 & 0.05 \\
\hline dlGnRH-R-2A vs LH $\beta$ & $Y=0.1300+1.151 X$ & 0.892 & 0.05 & $Y=0.1990+0.993 X$ & 0.811 & 0.05 \\
\hline \multicolumn{7}{|l|}{ Levels/gene expression } \\
\hline LH pit $v s$ LH $\beta$ mRNA & $Y=4.638+2.297 X$ & 0.885 & 0.1 & $Y=6.396+2833 X$ & 0.973 & 0.05 \\
\hline \multicolumn{7}{|l|}{ Levels/levels } \\
\hline LH pit $v s$ LH plasma & $Y=1.780+1.276 X$ & 0.966 & 0.05 & $Y=2.676+0.995 X$ & 0.887 & 0.1 \\
\hline
\end{tabular}


the female-dominant one at $200 \mathrm{dph}$. The pattern of variation of FSH $\beta$ during the monitoring period was similar to that of GPo (Figs. 3C and D). At 200-300 dph, there was a trend towards higher levels of FSH $\beta$ expression in the male- $(>1.5$ ratio FSH $\beta / 18 \mathrm{~S})$ than in the female-dominant $(\leq 1$ ratio FSH $\beta / 18 S$ ) population, though no significant difference was detected. In the male-dominant population (Fig. $3 \mathrm{C}$ ) the highest levels of FSH $\beta$ transcript appeared at $200 \mathrm{dph}$, coinciding with the onset of male sexual differentiation, and were maintained until the experiment was terminated. Similar pattern of expression was observed in the female-dominant population (Fig. $3 \mathrm{D})$, where the FSH $\beta$ mRNA levels displayed a significant rise $(\mathrm{P} \leq 001)$ at $150 \mathrm{dph}$, coinciding with the onset of sexual differentiation in females. The expression pattern of $\mathrm{LH} \beta$ differed from that of FSH $\beta$, in that LH $\beta$ exhibited a steady increase from $150 \mathrm{dph}$, peaking at the end of the experimen-

A

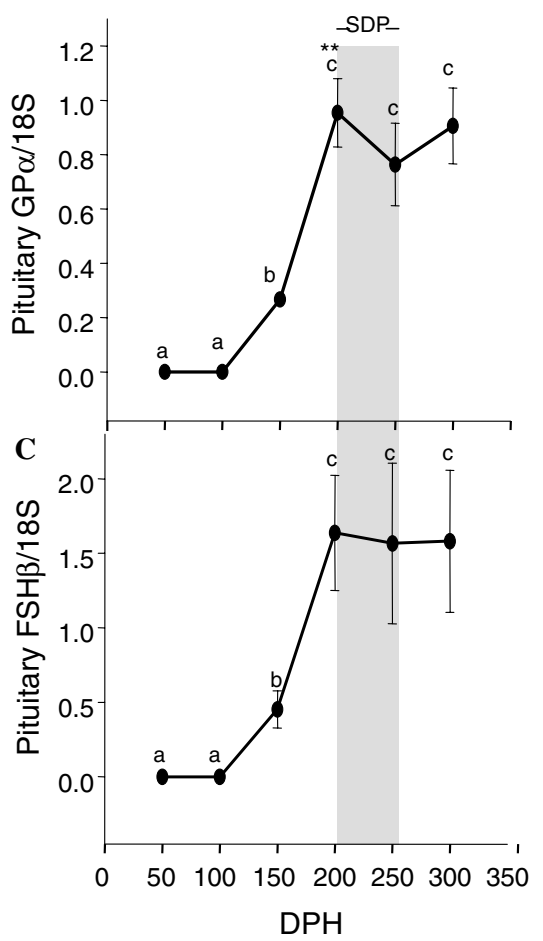

B Female population

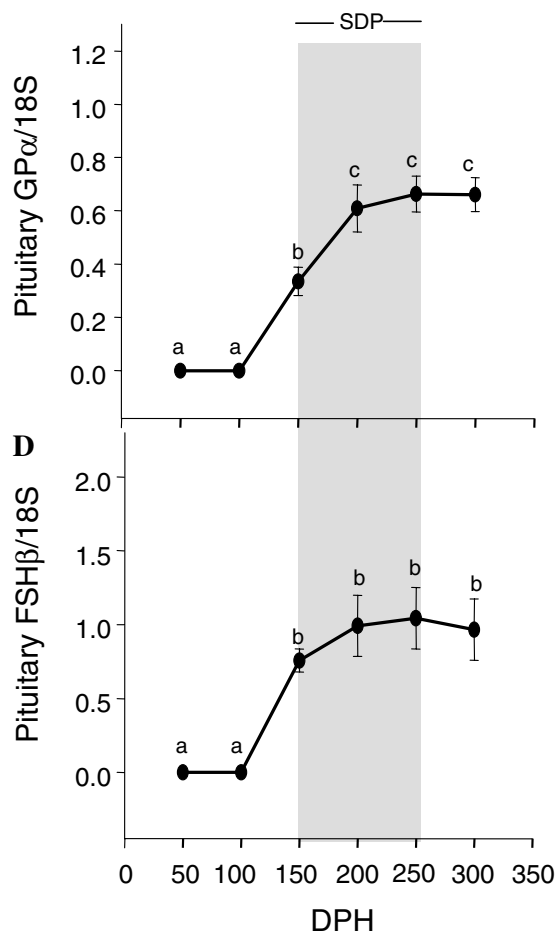

Figure 3. Temporal variations of the levels of pituitary glycoprotein $\alpha(\mathrm{GP} \alpha) \mathrm{mRNA}$ (A and B) and pituitary FSH $\beta$ mRNA (C and D) in male and female populations of European sea bass during the first year of life. Asterisks indicate significant $(* * \mathrm{P} \leq 0.01)$ differences between two populations at equivalent dates. Rest of the legends refer to Fig. 1. 
tal period in both populations (Figs. 4A and B). At 200-300 dph, the LH $\beta$ mRNA levels of the male-dominant population showed a tendency to be higher than those of the female-dominant one. The FSH $\beta$ expression ratio was higher than that of the other two subunits (GP $\alpha$ and LH $\beta$ ) and the lowest magnitude of transcript corresponded to the $\mathrm{LH} \beta$ gene. A regression analysis indicated that the changes of the expression of $\mathrm{LH} \beta$ were directly related to those of GP $\alpha$, in both the male- and female-dominant populations $(\mathrm{r}=0.975, \mathrm{P} \leq 0.05$ and $\mathrm{r}=0.972, \mathrm{P} \leq 0.05$, respectively $)$ and the correlation between FSH $\beta$ and GP $\alpha$ mRNA was even higher in both populations $(r=$ $0.990, \mathrm{P} \leq 0.01$ and $\mathrm{r}=0.977, \mathrm{P} \leq 0.05$, respectively) (Table 2). Similarly, the changes of expression of dlGnRH-R-2A as a function of the expression of GP $\alpha$, FSH $\beta$ and LH $\beta$ were highly correlated in both male- $(r=0.959, \mathrm{P} \leq$ $0.01 ; \mathrm{r}=0.932, \mathrm{P} \leq 0.01$ and $\mathrm{r}=0.892, \mathrm{P} \leq 0.05$, respectively) and femaledominant $(\mathrm{r}=0.873, \mathrm{P} \leq 0.05 ; \mathrm{r}=0.843, \mathrm{P} \leq 0.05$ and $\mathrm{r}=0.811, \mathrm{P} \leq 0.05$, respectively) populations (Table 2 ).

\subsection{Pituitary content and plasma levels of LH}

At $150 \mathrm{dph}$, the pituitary levels of LH in the male-dominant population were very low (Fig. $4 \mathrm{C}$ ). In the following days, a steady and significant increase ( $\mathrm{P} \leq 0.001)$ was observed until $250 \mathrm{dph}$, followed by a fivefold surge at $300 \mathrm{dph}$. In the female-dominant population, there was also a continual increase in pituitary LH content, with a sixfold increase at $250 \mathrm{dph}$ and a two-

fold increase at 300 with respect to the previous one. At $250 \mathrm{dph}$, pituitary LH content in the female population was significantly higher $(\mathrm{P} \leq 0.01)$ than that of the male one (Fig. 4D). The correlation between LH $\beta$ mRNA levels and pituitary LH content was calculated from the beginning of the sex differentiation period $(150 \mathrm{dph})$ to the end of the experiment, which coincided with the earlier stages of male tentative gonadal development (TGD, i.e. period of early testicular recrudescence or partial spermatogenesis which occurs in prepubescent male European sea bass) (Begtashi et al., 2004). This relationship was estimated separately for male- and female-dominant populations $(\mathrm{r}=0.885, \mathrm{P} \leq 0.1$ and $\mathrm{r}=0.973, \mathrm{P}=0.05$, respectively; Table 2$)$.

The male-dominant population exhibited a steady increase of plasma LH during the experiment, whereas the female-dominant population displayed a significant increase only at $250 \mathrm{dph}$ (Figs. $4 \mathrm{E}$ and F). At this time, plasma LH levels of the female-dominant population were significantly higher $(\mathrm{P} \leq$ 
0.05) than those of the male population. However, at $300 \mathrm{dph}$, plasma LH in the female population was reduced significantly and was lower than that in the male population (Fig. 4F). A correlation between the content of LH in the pituitary and the plasma LH levels of the male- and female-dominant populations $(\mathrm{r}=0.966, \mathrm{P} \leq 0.05$ and $\mathrm{r}=0.887, \mathrm{P}=0.1$, respectively) are shown in Table 2.

\section{Male population}

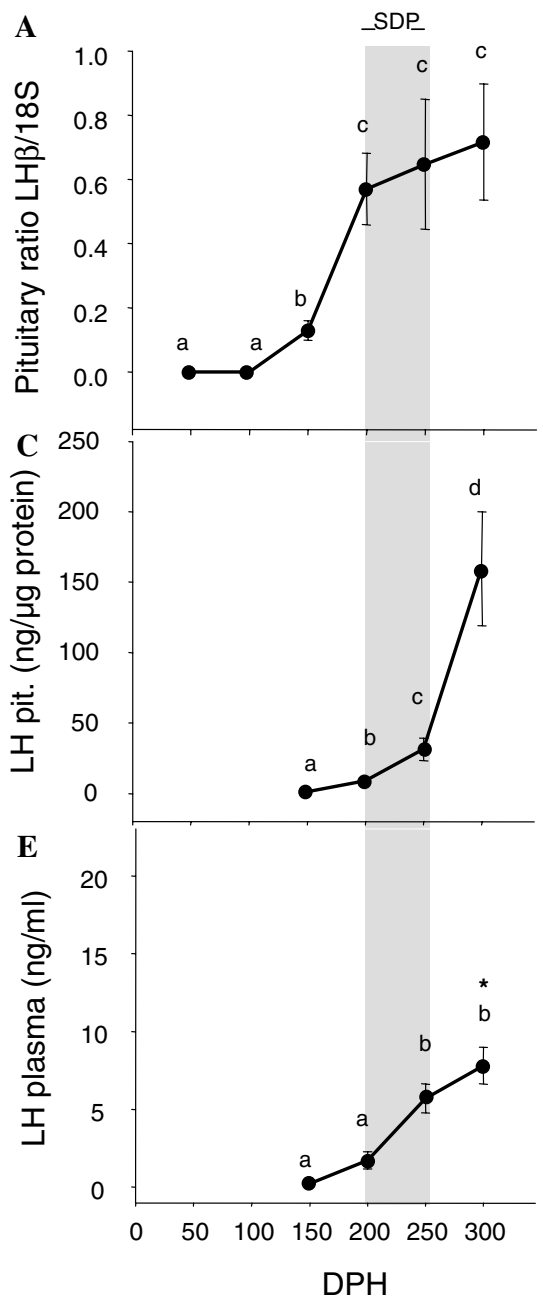

Female population

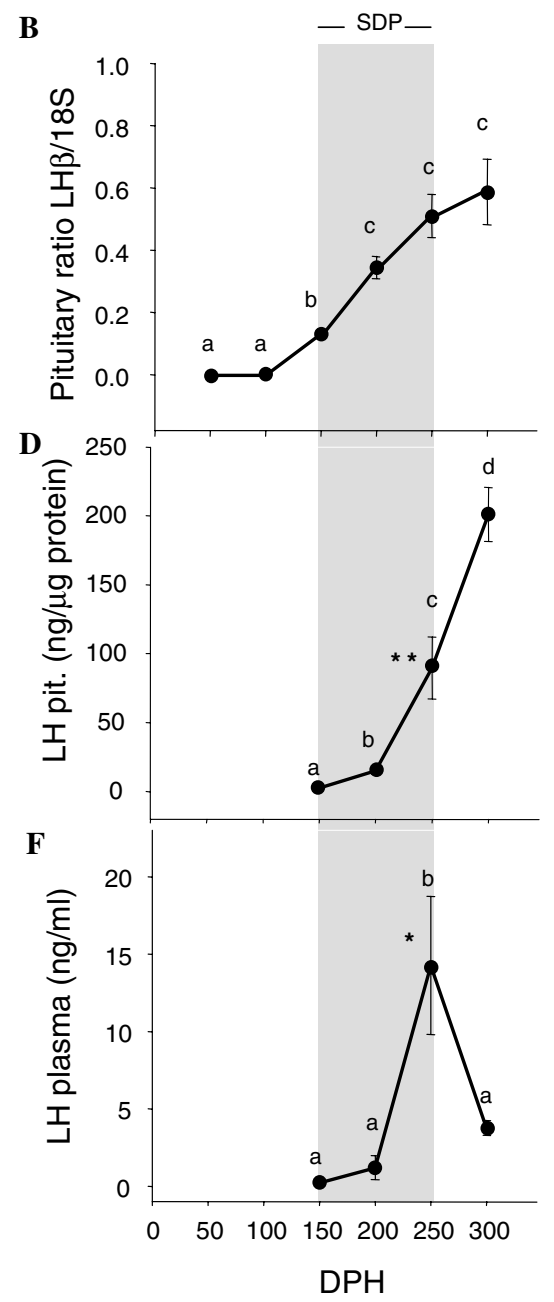

Figure 4. Temporal variation of pituitary LH $\beta$ mRNA (A and B), pituitary LH content (C and D) and plasma LH levels ( $E$ and F) in male- and female-dominant populations of European sea bass during the first year of life. Asterisks indicate significant (" $\mathrm{P} \leq 0.05$; $\left.{ }^{* *} \mathrm{P} \leq 0.01\right)$ differences between two populations at equivalent dates. Rest of the legends refer to Fig. 1. 


\section{Discussion}

The objective of this study was to investigate the endocrine control of sexual differentiation in European sea bass, starting early in development (50 dph). To date, size grading is the only non-hormonal method available in the European sea bass for the production of single-sex-dominant populations, and is based on the existence of a strong relation between growth and phenotypic sex differentiation early in development (Blázquez et al., 1999; Saillant et al., 2003). Intensive grading between 2 and 8 months after hatching increased the percentage of females among larger fish up to $96.5 \%$, whereas the percentage of males among smaller fish increased to $69.8 \%(\mathrm{~Pa}-$ padaki et al., 2005). The first histological signs of gonadal differentiation in female European sea bass took place around $150 \mathrm{dph}$ and in males around $200 \mathrm{dph}$, whereas complete gonadal differentiation occurred at around 250 dph in both sexes (Papadaki et al., 2005). As sex could not be determined macroscopically at the time of sampling and collection of the various tissues prior to $250 \mathrm{dph}$, it is likely that some sampled individuals from the female-dominant population were indeed males, whereas some individuals from the male-dominant population were indeed females. Since the femaledominant population consisted of $91 \%$ females already after the first grading at $66 \mathrm{dph}$, then the possibility of sampling a male in this population was negligible $(<10 \%)$. On the contrary, the possibility of some female individuals contributing to the mean values of the male-dominant population during the sampling times between 100 and $200 \mathrm{dph}$ is substantial. Still, given the creation of an almost monosex female population in the present study, any significant differences between the male- and female-dominant population can be attributed to the male component of the first, thus considering those as "male" values.

The present study shows that both male- and female-dominant populations had a peak of brain sbGnRH gene expression, coinciding with the onset of sex differentiation. In both populations, levels of sGnRH mRNA changed in parallel to those of sbGnRH. In addition, the patterns of sb$\mathrm{GnRH}$ and sGnRH gene expression were unimodal in the male-dominant population and bimodal in the female one. These results suggest that the onset of sex differentiation, as well as its accomplishment, requires high sbGnRH and sGnRH transcriptional activity, with differences due to age and sex. Of the three forms of GnRH present in the brain of the European 
sea bass, sbGnRH is considered as the hypophysotropic one and its role as the natural releaser of LH has been clearly demonstrated (Forniés et al., 2002; González-Martínez et al., 2001; González-Martínez et al., 2002a,b; Rodríguez et al., 2000). Furthermore, immunocytochemical studies of the distribution of cells and fibers expressing the different prepro-GnRHs in the brain and pituitary of European sea bass (González-Martínez et al., 2002b) demonstrated that the proximal pars distalis (PPD) and the border of the pars intermedia (PI), where gonadotropes are located, were strongly innervated with sbGnRH associated peptide immunoreactive fibers (sbGAP-ir) and receive, as well, a few sGnRH-associated peptide immunoreactive fibers (sGAP-ir). In addition, sbGnRH and sGnRH share a common origin near the olfactory system and exhibit overlapping patterns of distribution in the anterior forebrain as observed recently in the Atlantic croaker and medaka (Mohamed et al., 2005; Okubo et al., 2006). These results support the main role of sbGnRH in the stimulation of the secretion of gonadotropins in these species and to some extent suggest the possible participation of sGnRH in the gonadotropic function. The pituitary content of sbGnRH and sGnRH showed sex-related differences and displayed an inverse pattern to that of the brain. Nevertheless, the pituitary content of sbGnRH was about twofold higher than that of sGnRH suggesting a prevailing role in the gonadotropic function. The fact that high levels of sbGnRH in the pituitary appeared just before or at the beginning of sex differentiation, in close association with high sbGnRH brain expression, suggests that the onset of sex differentiation requires a high transcriptional activity of sbGnRH followed by an active synthesis and transport up to the gonadotropes at the distal pituitary. Rodríguez et al. (2000) demonstrated that pituitary sbGnRH peaked around the time of sex differentiation, further supporting the role of sbGnRH in gonadal differentiation in European sea bass.

Recently, Moncaut etal. (2005) have identified five different GnRH-R genes (dlGnRH-R-1A, dlGnRH-R-1B, dlGnRH-R-2A, dlGnRH-R-2B and dlGnRH$\mathrm{R}-2 \mathrm{C}$ ) in the European sea bass. Because the dlGnRH-R-2A is a receptor subtype for the most abundant GnRHs in the forebrain of this species, i.e. sbGnRH and sGnRH (González-Martínez et al., 2002a,b; González-Martínez et al., 2004), its gene expression was examined in the present study. The pattern of pituitary dlGnRH-R-2A mRNA expression in the male-dominant population was similar to the expression of sbGnRH and sGnRH. In the female-dominant population, pituitary dlGnRH-R-2A mRNA levels peaked 
coincidently with the second surge of brain sbGnRH and sGnRH gene expression. The significant correlation between sbGnRH and dlGnRH-R-2A gene expression suggests that changes in brain sbGnRH gene expression are reflected in the expression of its receptor at the pituitary level. The dlGnRHR-2A is highly expressed in European sea bass pituitary gonadotropic cells and is considered as the GnRH-R responsible for the stimulatory actions of sbGnRH and sGnRH on GtH release (González-Martínez et al., 2004). In adult females, the highest expression of dlGnRH-R-2A at the pituitary occurs at the time of maximum ovarian activity during vitellogenesis in November (González-Martínez et al., 2004). In males, sbGnRH pituitary levels were high at the onset of puberty, when the first significant increase of the gonadosomatic index (GSI) and plasma levels of testosterone (T) and 11-ketoT (11-KT) occurred (Rodríguez et al., 2000). In the present study, the strong correlation between gene expression of sbGnRH and dlGnRH-R-2A, in both sexes, is a good indicator of their possible involvement in sex differentiation as well.

In both populations, pituitary changes of GP $\alpha, \mathrm{FSH} \beta$ and $\mathrm{LH} \beta$ gene expression displayed similarities to the pattern of variation of dlGnRH-R-2A, with the pattern of expression of FSH $\beta$ exhibiting a higher correlation than LH $\beta$. In the pituitary of adult female European sea bass, dlGnRH-R-2A expression activity was mainly detected in LH cells but also in some FSH ones (González-Martínez et al., 2004). Therefore, the similar profiles of synthesis of sbGnRH and sGnRH, and dlGnRH-R-2A and GtHs may indicate the important role of these GnRHs in inducing GtH synthesis and more specifically FSH during the period of sex differentiation in European sea bass. It is important to note that precisely at the onset of male and female sex differentiation, FSH $\beta$ transcriptional activity attained its highest values, which were maintained elevated throughout the study period. On the contrary, LH $\beta$ mRNA exhibited a progressive and steady increase up to $300 \mathrm{dph}$, when males attained the tentative gonadal development (TGD) or even spermiation, and females were completely differentiated. Furthermore, the level of expression of FSH $\beta$ was higher than that of $\mathrm{LH} \beta$ (2.6x and $2 \mathrm{x}$ in male- and female-dominant populations, respectively). Collectively, these results suggest that mRNA expression of LH $\beta$ may not be entirely associated with the onset of sex differentiation, while FSH transcriptional activity seems to be more involved in this process. It has been suggested that the mechanisms regulating FSH $\beta$ gene expression in several species of teleosts, including Eu- 
ropean sea bass, may be different from that of LH $\beta$, and may depend on the gender and the stage of sexual ontogeny (Gen et al., 2000; Hassin et al., 1995, 1998; Kandel-KWr et al., 2002; Klausen et al., 2001; Kumakura et al., 2004; Mateos et al., 2002; Sohn et al., 2001). Collectively, these results show that the pituitary levels of FSH $\beta$ exhibit gender- and reproductive-phase-dependent variation and suggest a prevailing role of FSH in European sea bass sex differentiation, as observed in Cichlasoma dimerus, another perciform species (Pandolfi et al., in press). Unfortunately in the present study it could not be confirmed whether the rise of sbGnRH or sGnRH at the onset of sex differentiation was associated to an increase of pituitary or plasma levels of FSH, since an assay to measure this hormone in European sea bass has not been developed yet. Nevertheless, it is presumed that high levels of FSH $\beta$ transcripts in the pituitary during sex differentiation may be indicative also of high FSH content in the pituitary and elevation of its plasma levels, as observed in salmonids (Gómez et al., 1999; Dickey and Swanson, 2000). In fact, in salmonids, it has been suggested that FSH release may be largely constitutive and possibly regulated primarily via control of transcription (Swanson et al., 2003).

The involvement of $\mathrm{GnRH}$ and GtHs in gonadal differentiation has already been suggested in other species such as the rainbow trout (Oncorhynchus mykiss), tilapia (Oreochromis spp.), pejerrey (Odontesthes bonariensis) and C. dimerus (Feist and Schreck, 1996; Miranda et al., 2001, 2003; Pandolfi et al., 2002, in press; Parhar, 1997). In the European sea bass, the brain machinery responsible for the control of sex differentiation and reproduction is formed well before gonadal development (González-Martínez et al., 2004; Piferrer et al., 2005), and the present results suggest that during sex differentiation sbGnRH regulates the synthesis and release of FSH, which in turn reaches the gonad-stimulating steroidogenesis. A direct stimulation of P450aromA expression by FSH in fish oocytes has been demonstrated (Montserrat et al., 2004), and very recent studies showed that purified European sea bass FSH promotes ovarian synthesis of E2 (Molés et al., in press). Furthermore, the high levels of plasma E2 found at 200 dph in the femaledominant population (Papadaki et al., 2005) suggest that this is indeed the case, as previously observed in tilapia (D'Cotta et al., 2001). Likewise, recent studies on the expression of P450aromB in the brain of European sea bass demonstrated that females exhibited higher mRNA levels than males at the time of gonad sex differentiation (Blázquez and Piferrer, 2004). Finally, it is 
interesting to note that in mammals it has been described that the aromatization of $\mathrm{T}$ to $\mathrm{E} 2$ is the predominant prevailing regulator of FSH secretion (Hayes et al., 2001). Taken together, all this suggests a role of sbGnRH on FSH synthesis and release and their effects on steroidogenesis, both at the brain and the gonad level during sex differentiation in European sea bass.

In the present study, the pituitary content of LH in both populations was correlated with the mRNA levels of $\mathrm{LH} \beta$, indicating that transcriptional and synthetic processes are similarly regulated in European sea bass. However, sex differences were observed in the pattern of plasma LH. In the maledominant population there was a steady increase of plasma LH levels from 150 dph onwards, showing a close relationship with the expression of LH $\beta$ and pituitary LH content. On the contrary, the female population exhibited a significant decrease in plasma LH levels at $300 \mathrm{dph}$, despite the increasing pituitary LH content. This suggests that LH release was arrested through a highly regulated pathway, probably in response to the decrease of sbGnRH input to the pituitary and expression of dlGnRH-R-2A. It has been claimed that LH controls the last stages of the reproductive cycle, while FSH mainly regulates the earlier stages of reproduction such as initiation of meiosis and early spermatogenesis (Gómez et al., 1999; Hassin et al., 2000; Planas and Swanson, 1995; Swanson et al., 1989). In the present study, the observed increase of plasma LH levels from the beginning of sex differentiation toward the end of the studied period, when males were spermiating, confirms this role. Moreover, the profile of LH in the male population correlated well with the presence of precocious males and the progressive increase of plasma 11 KT (Papadaki et al., 2005), which is the regulator of spermatogenesis in teleosts (Amer et al., 2001; Kobayashi et al., 1991; Miura et al., 1991; Schulz and Miura, 2002; Rodríguez et al., 2005). On the contrary, LH plasma levels in the female population did not correlate well with pituitary transcription or synthesis of LH, in agreement with the absence of significant increases, at this time, of plasma E2 and the presence of only primary oocytes in the ovaries (Papadaki et al., 2005).

In conclusion, the present study supports the role of sbGnRH and possibly sGnRH in gonadal differentiation through an enhancement of FSH $\beta$ gene expression. A sexual dimorphism of these $\mathrm{GnRH}$ forms either at the transcription or synthesis level strengthens the thought that differential neuro-hormonal regulation is required for each sex. Differential endocrine regulation seems to occur at further stages of gonadal development on which 
a steady increase of the levels of transcription, synthesis, and release of LH are of paramount importance for maturation and spermiation.

\section{Acknowledgments}

This work was supported by a EU grant under the Quality of Life and Management of Living Resources programme (contract Q5RS-2000-31365) to S.Z. and C.C.M. and a MEC and GV grants (AGL2002-10024E and GV04B-591, respectively) to S.Z. G.M. was supported by a doctoral I3P fellowship from the CSIC, Spain. We thank L. Rodríguez, S. Ibañez, and J. Beltran for assistance in tissue preparation and result analysis. We are indebted to F. Piferrer and A. Felip for critically reviewing the manuscript.

\section{References}

Amer, M.A., Miura, T., Miura, C., Yamauchi, K., 2001. Involvement of sex steroid hormones in the early stages of spermatogenesis in Japanese huchen (Hucho perry). Biol. Reprod. 65, 1057-1066.

Baroiller, J.F., Guigen, Y., Fostier, A., 1999. Endocrine and environmental aspects of sex differentiation in fish. Cell Mol. Life Sci. 55, 910-931.

Begtashi, I., Rodríguez, L., Molés, G., Zanuy, S., Carrillo, M., 2004. Longterm exposure to continuous light inhibits precocity in juvenile male European sea bass (Dicentrarchus labrax, L.). I. Morphological aspects. Aquaculture 241, 539-559.

Blázquez, M., Piferrer, F., 2004. Cloning, sequence analysis, tissue distribution, and sex specific expression of the neural form of $\mathrm{P} 450$ aromatase in juvenile sea bass (Dicentrarchus labrax). Mol. Cell Endocrinol. 219, 83-94.

Blázquez, M., Zanuy, S., Carrillo, M., Piferrer, F., 1999. Sex ratios in offspring of sex reversed sea bass (Dicentrarchus labrax L.) and the relation between growth and phenotypic sex differentiation. J. Fish Biol. 55, 916-930.

Bogerd, J., Granneman, C.M., Schulz, R.W., Vischer, H.F., 2005. Fish FSH receptors bind $\mathrm{LH}$ : how to make the human FSH receptor to be more fishy?. Gen. Comp. Endocrinol. $142,34-43$.

Bradford, M.M., 1976. A rapid and sensitive method for the quantization of microgram quantities of protein utilizing the principle of protein-dye binding. Anal. Biochem. 72, $248-254$.

Carrillo, M., Zanuy, S., Piferrer, F., Blázquez, M., Felip, A., Martínez-Rodríguez, G., Ramos, J., 1999. Sex control in sea bass (Dicentrarchus labrax L.): present and future prospects. In: Xu, H.S., Colwell, R. (Eds.), Proceedings of the International Symposium on Progress and Prospect of Marine Biotechnology (ISPPMB'98), Qingdao, China, pp. 22-31.

D’Cotta, H., Fostier, A., Guiguen, Y., Govoroun, M., Baroiller, J.F., 2001. Aromatase play a key role during normal and temperature-induced sex differentiation of tilapia Oreochromis niloticus. Mol. Rep. Dev. 59, 265-276.

Devlin, R.H., Nagahama, Y., 2002. Sex determination and sex differentiation in fish: an 
overview of genetic, physiological, and environmental influences. Aquaculture 208, 191-364.

Dickey, J.T., Swanson, P., 2000. EVects of salmon gonadotropin-releasing hormone on follicle stimulating hormone secretion and subunit gene expression in coho salmon (Oncorhynchus kisutch). Gen. Comp. Endocrinol. 118, 436-449.

Divanach, P., Kentouri, M., 2000. Hatchery techniques for specific diversification in Mediterranean finfish larviculture. In: Basurco, B., Pedini, M. (Eds.), Cahiers Options Méditerranénnes, Vol. 47, Recent Advances in Mediterranean Aquaculture Finfish Species Diversification. C.I H.E.A.M., Zaragoza, pp. 75-95.

EEC, 1986. Council Directive 86/609 EEC for the protection of animals used for experimental and other scientific purposes. Official Journal L358 (18/12/1986), 1-28.

Feist, G., Schreck, C.B., 1996. Brain-pituitary-gonadal axis during early development and sexual differentiation in the rainbow trout, Oncorhynchus mykiss. Gen. Comp. Endocrinol. 102, 394-409.

Forniés, M.A., Carrillo, M., Mañanós, E., Sorbera, L., Zohar, Y., Zanuy, S., 2002. Relative potency of the forms of $\mathrm{GnRH}$ and their analogs on LH-secretion in sea bass (Dicentrarchus labrax). J. Fish Biol. 63, 69-73.

Gen, K., Okuzawa, K., Sentihilkumaran, B., Tanaka, H., Moriyama, S., Kagawa, H., 2000. Unique expression of gonadotropin-I and -II subunit genes in male and female red sea bream (Pagrus major) during sexual maturation. Biol. Reprod. 63, 308-319.

Gómez, J.M., Weil, C., Ollitrault, M., Le Bail, P.Y., Breton, B., Le Gac, F., 1999. Growth hormone $(\mathrm{GH})$ and gonadotropin subunit gene expression and pituitary and plasma changes during spermatogenesis and oogenesis in rainbow trout (Oncorhynchus mykiss). Gen. Comp. Endocrinol. 113, 413-428.

González-Martínez, D., Zmora, N., Anglade, I., Madigou, T., Zanuy, S., Muñoz-Cueto, J.A., Zohar, Y., Elizur, A., Kah, O., 2001. Differential expression of the three different preproGnRH (gonadotropin-releasing hormone) messengers in the brain of the European sea bass (Dicentrarchus labrax). J. Comp. Neurol. 429, 144-155.

González-Martínez, D., Zmora, N., Zanuy, S., Sarasquete, C., Elizur, A., Kah, O., MuñozCueto, J.A., 2002a. Developmental expression of three different prepro-GnRH messengers in the brain of the European sea bass (Dicentrarchus labrax). J. Chem. Neuroanat. 23, 255-267.

González-Martínez, D., Zmora, N., Mañanós, E., Saligaut, D., Zanuy, S., Zohar, Y., Elizur, Y., Kah, O., Muñoz-Cueto, J.A., 2002b. Immunohistochemical localization of three different prepro-GnRHs in the brain of the European sea bass (Dicentrarchus labrax) using antibodies to the corresponding GnRH-associated peptides. J. Comp. Neurol. 446, 95-113.

González-Martínez, D., Madigou, T., Mañanós, E., Cerdá-Reverter, J.M., Zanuy, S., Kah, O., Muñoz-Cueto, J.A., 2004. Cloning and expression of gonadotropin-releasing hormone receptor in the brain and pituitary of the European sea bass: an in situ hybridization study. Biol. Reprod. 70, 1380-1391.

Hassin, S., Elizur, A., Zohar, Y., 1995. Molecular cloning and sequence analysis of striped bass (Morone saxatilis) gonadotrophin-I and -II subunits. J. Mol. Endocrinol. 15, 23-35.

Hassin, S., Gothilf, Y., Blaise, O., Zohar, Y., 1998. Gonadotropin-I and -II subunit gene expression of male stripped bass (Morone saxatilis) after gonadotropin-releasing hormone 
analogue injection: quantification using an optimized ribonuclease protection assay. Biol. Reprod. 58, 1233-1240.

Hassin, S., Holland, C.M., Zohar, Y., 2000. Early maturity in the male striped bass, Morone saxatilis: follicle-stimulating hormone and luteinizing hormone gene expression and their regulation by gonadotropin-releasing hormone analogue and testosterone. Biol. Reprod. 63, 1691-1697.

Hayes, F.J., Decruz, S., Seminara, S.B., Beopple, P.A., Crowley Jr., W.F., 2001. Differential regulation of gonadotropin secretion by testosterone in the human male: absence of a negative feedback effect of testosterone on follicle-stimulating hormone secretion. J. Clin. Endocrinol. Metab. 86, 53-58.

Holland, M.C.H., Gothilf, Y., Meiri, I., King, J.A., Okuzawa, K., Elizur, A., Zohar, Y., 1998. Levels of the native forms of GnRH in the pituitary of the gilthead sea bream, Sparus aurata, at several stages of the gonadal cycle. Gen. Comp. Endocrinol. 112, 394-405.

Kah, O., Zanuy, S., Pradelles, P., Cerdá, J., Carrillo, M., 1994. An enzyme immunoassay for salmon gonadotropin-releasing hormone and its application to the study of the effect of diet on brain and pituitary GnRH in the sea bass, Dicentrarchus labrax. Gen. Comp. Endocrinol. 95, 464-474.

Kandel-Kfir, M., Gur, G., Melamed, P., Zilberstein, Y., Cohen, Y., Zmora, N., Kobayashi, M., Elizur, A., Yaron, Z., 2002. Gonadotropin response to GnRH during sexual ontogeny in the common carp, Cyprinus carpio. Comp. Biochem. Physiol. B 132, 17-26.

Klausen, C., Chang, J.P., Habibi, H.R., 2001. The effect of gonadotropin-releasing hormone on growth hormone and gonadotropin subunit gene expression in the pituitary of goldfish, Carassius auratus. Comp. Biochem. Physiol. B 129, 511-516.

Kobayashi, M., Aida, K., Stacey, N.E., 1991. Induction of testis development by implantation of 11-ketotestosterone in female goldfish. Zool. Sci. 8, 389-393.

Kumakura, N., Okuzawa, K., Gen, K., Yamaguchi, S., Lim, B.-S., Kagawa, H., 2004. Effects of gonadotropin-releasing hormone on pituitary-ovarian axis of one-year old pre-pubertal red sea bream. Gen. Comp. Endocrinol. 138, 112-115.

Lethimonier, C., Madigou, T., Muñoz-Cueto, J.A., Lareyre, J.J., Kah, O., 2004. Evolutionary aspects of GnRHs, GnRH neuronal systems and GnRH receptors in teleost fish. Gen. Comp. Endocrinol. 135, 1-16.

Mañanós, E.L., Swanson, P., Stubblefield, J., Zohar, Y., 1997. Purification of gonadotropin II for a teleost fish, the hybrid striped bass, and development of a specific enzyme-linked immunosorbent assay. Gen. Comp. Endocrinol. 108, 209-222.

Mateos, J., Mañanós, E., Carrillo, M., Zanuy, S., 2002. Regulation of follicle-stimulating hormone (FSH) and luteinizing hormone ( $\mathrm{LH})$ gene expression by gonadotropin-releasing hormone $(\mathrm{GnRH})$ and sexual steroids in the Mediterranean sea bass. Comp. Biochem. Physiol. B 132, 75-86.

Mateos, J., Mañanós, E., Martínez-Rodríguez, G., Carrillo, M., Querat, M., Zanuy, S., 2003. Molecular characterization of sea bass gonadotropin subunits ( $\alpha, \mathrm{FSH} \beta$ and $\mathrm{LH} \beta$ ) and their expression during the reproductive cycle. Gen. Comp. Endocrinol. 13, 216.

Mateos, J., Mañanós, E., Swanson, P., Carrillo, M., Zanuy, S., 2006. Purification of luteinizing hormone (LH) in the sea bass (Dicentrarchus labrax L.) and development of specific immunoassay (ELISA). Cienc. Marinas 32, 271-283.

Miranda, L.A., Strussmann, C.A., Somoza, G.M., 2001. Immunocytochemical identification of GtH1 and GtH2 cells during the temperature-sensitive period for sex determina- 
tion in pejerrey, Odontestes bonaerensis. Gen. Comp. Endocrinol. 124, 45-52.

Miranda, L.A., Strobl-Mazzulla, P.H., Strussmann, C.A., Parhar, I., Somoza, G.M., 2003. Gonadotropin releasing hormone neuronal development during the sensitive period of temperature sex determination in the pejerrey fish, Odontestes bonaerensis. Gen. Comp. Endocrinol. 132, 444-453.

Miura, T., Yamauchi, K., Nagahama, Y., Takahashi, H., 1991. Induction of spermatogenesis in male Japanese eel, Anguilla japonica, by single injection of human chorionic gonadotropin. Zool. Sci. 8, 63-73.

Mohamed, J.S., Thomas, P., Khan, I.A., 2005. Isolation, cloning, and expression of three pre pro-GnRH mRNAs in Atlantic croaker brain and pituitary. J. Comp. Neurol. 488, 384-395.

Molés, G., Goméz, A., Rocha, A., Carrillo, M., Zanuy, S., 2006. Purificación y caracterización de la hormona estimulante del foliculo (FSH) de lubina (Dicentrarchus labrax). In: Canario, A., Power, D. (Eds.), Avances en Endocrinología Comparada, Vol. III. University of the Algarbe, Faro, Portugal.

Moncaut, N., Somoza, G., Power, D.M., Canario, A.V.M., 2005. Five gonadotropin-releasing hormone receptors in a teleost fish: isolation, tissue distribution and phylogenetic relationships. J. Mol. Endocrinol. 34, 767-779.

Montserrat, N., Gonzalez, A., Mendez, E., Piferrer, F., Planas, J.V., 2004. Effects of follicle stimulating hormone on estradiol-17 beta production and P-450 aromatase (CYP19) activity and mRNA expression in brown trout vitellogenic ovarian follicles in vitro. Gen. Comp. Endocrinol. 137, 123-131.

Nagahama, Y., 1999. Gonadal steroid hormones: major regulators of gonadal sex differentiation and gametogenesis in fish. In: Norberg, B., Kjesbu, O.S., Taranger, G.L., Andersson, E., Stefansson, S.O. (Eds.), Proceedings of the Sixth International Symposium on Reproductive Physiology of Fish. University of Berguen, Berguen, Norway, pp. 211-222.

Nakamura, M., Kobayashi, T., Chang, X.-T., Nagahama, Y., 1998. Gonadal sex differentiation in teleost fish. J. Exp. Biol. 281, 362-372.

Okubo, K., Sakai, F., Lau, E.L., Yoshizaki, G., Takeuchi, Y., Naruse, K., Aida, K., Nagahama, Y., 2006. Forebrain gonadotropin-releasing hormone neuronal development: insights from transgenic medaka and the relevance to X-linked Kallman syndrome. Endocrinology 147, 1076-1084.

Pandolfi, M., Parhar, I.S., Ravaglia, M.A., Meijide, F.J., Maggese, M.C., Paz, D.A., 2002. Ontogeny and distribution of gonadotropin-releasing hormone ( $\mathrm{GnRH}$ ) neuronal systems in the brain of the cichlid fish Cichlasoma dimerus. Anat. Embryol. 205, 271-281.

Pandolfi, M., Lo Nostro, F., Shimizu, A., Pozzi, A.G., Meijide, F.J., Rey Vazquez, G., Maggese, M.C., 2006. Identification of immunoreactive FSH and LH cells in the cichlid fish Cichlasoma dimerus during ontogeny and sexual differentiation. Anat. Embryol., doi:10.1007/s00429-006-0086-0.

Papadaki, M., Piferrer, F., Zanuy, S., Maingot, E., Divanach, P., Mylonas, C., 2005. Growth, sex differentiation and gonad and plasma levels of sex steroids in male- and femaledominant populations of European sea bass obtained through repeated size grading. J. Fish. Biol. 66, 938-956.

Parhar, I.S., 1997. GnRH in tilapia: three genes, three origins and their roles. In: Parhar, I.S., Sakuma, S. (Eds.), GnRH Neurons: Genes to Behaviour. Brain Suppan, Tokyo, Ja- 
pan, pp. 99-122.

Piferrer, F., Blázquez, M., Navarro, L., González, A., 2005. Genetic, endocrine, and environmental components of sex determination and differentiation in the European sea bass (Dicentrarchus labrax L.). Gen. Comp. Endocrinol. 142, 102-110.

Planas, J.V., Swanson, P., 1995. Maturation-associated changes in the response of the salmon testis to the steroidogenic actions of gonadotropins (GtH I and GtH II) in vitro. Biol. Reprod. 52, 697-704.

Planas, J.V., Athos, J., Goetz, F.W., Swanson, P., 2000. Regulation of ovarian steroidogenesis in vitro by follicle-stimulating hormone and luteinizing hormone during sexual maturation in salmonid fish. Biol. Reprod. 62, 1262-1269.

Prat, F., Sumpter, J.P., Tyler, C.R., 1996. Validation of radioimmunoassays for two salmon gonadotropins (GtH I and GtH II) and their plasma concentrations throughout the reproductive cycle in male and female rainbow trout (Oncorhynchus mykiss). Biol. Reprod. 54, 1375-1382.

Rodríguez, L., Carrillo, M., Sorbera, L.A., Soubrier, M.A., Mañanós, E., Holland, M.C.H., Zohar, Y., Zanuy, S., 2000. Pituitary levels of three forms of GnRH in the male European sea bass (Dicentrarchus labrax L.) during sex differentiation and first spawning season. Gen. Comp. Endocrinol. 120, 67-74.

Rodríguez, L., Begtashi, I., Zanuy, S., Carrillo, M., 2005. Long term exposure to continuous light inhibits precocity in European male sea bass (Dicentrarchus labrax, L.): hormonal aspects. Gen. Comp. Endocrinol. 140, 116-125.

Saillant, E., Fostier, A., Haffray, P., Menu, B., Laureau, S., Thimonier, J., Chatain, B., 2003. Effects of rearing density, size grading and parental factors on sex ratios of the sea bass (Dicentrarchus labrax L.) in intensive culture. Aquaculture 221, 183-206.

Schulz, R.W., Miura, T., 2002. Spermatogenesis and its endocrine control. Fish Physiol. Biochem. 26, 43-56.

Sohn, Y.C., Kobayashi, M., Aida, K., 2001. Regulation of gonadotropin $\beta$ subunit gene expression by testosterone and gonadotropin-releasing hormones in the goldfish, Carassius auratus. Comp. Biochem. Physiol. B 129, 419-426.

Swanson, P., 1991. Salmon gonadotropins: reconciling old and new ideas. In: Scott, A.P., Sumpter, J.P., Kime, D.E., Rolfe, M.S. (Eds.), Reproductive Physiology of Fish. Fish Symposium 91. Sheffield, pp. 2-7.

Swanson, P., Bernard, M., Nozaki, M., Kawauchi, H., Dickhoff, W.W., 1989. Gonadotropins I and II in juvenile coho salmon. Fish Physiol. Biochem. 7, 169-176.

Swanson, P., Dickey, J.T., Campbell, B., 2003. Biochemistry and physiology of fish gonadotropins. Fish Physiol. Biochem. 28, 53-59.

Yamamoto, T., 1969. Sex differentiation. In: Hoar, W., Randall, D. (Eds.), Fish Physiology. Academic Press, pp. 117-175.

Yaron, Z., Gur, G., Melamed, P., Rosenfeld, H., Levavi-Sivan, B., Elizur, A., 2001. Regulation of gonadotropin subunit genes in tilapia. Comp. Biochem. Physiol. B 129, 489-502.

Yaron, Z., Gur, G., Relamed, P., Rosenfeld, H., Elizur, H., Levavi-Sivan, B., 2003. Regulation of fish gonadotropins. In: International Review of Cytology-A Survey of Cell Biology 225, pp. 131-185.

Zmora, N., Gonzalez-Martínez, D., Muñoz-Cueto, J.A., Madigou, T., Mañanós-Sanchez, E., Zanuy, S., Zohar, Y., Kah, O., Elizur, A., 2002. The GnRH system in the European sea bass (Dicentrarchus labrax). J. Endocrinol. 172, 105-116. 



\section{Capítulo 4:}

\section{Purification and characterization of follicle-stimulating hormone from pituitary glands of sea bass (Dicentrarchus labrax)}

Gregorio Molés, Ana Gómez, Ana Rocha, Manuel Carrillo, Silvia Zanuy General and Comparative Endocrinology 158, 68-76 (2008) 



\begin{abstract}
Follicle-stimulating hormone (FSH) was purified from pituitaries of sea bass (Dicentrarchus labrax), and its biochemical and biological properties were studied. Sea bass FSH (sbsFSH) was purified by ethanol extraction-precipitation (40-85\%), followed by anion-exchange chromatography on a LKB Ultropac TSK-DEAE column using a linear gradient of ammonium bicarbonate (50-1000 $\mathrm{mM})$ and reverse phase chromatography on a RESOURCE 15RPC column with a linear gradient of acetonitrile (0-50\%), using a FPLC system. The molecular mass of the purified sbsFSH, estimated by mass spectrometry, was of $28.5 \mathrm{kDa}$ for the dimer, $12.6 \mathrm{KDa}$ for the glycoprotein $\alpha(\mathrm{GP} \alpha)$ and $13.6 \mathrm{KDa}$ for FSH $\beta$ subunits. After separation by SDS-PAGE under reducing condition, the intact sbsFSH was dissociated in the respective subunits (GP $\alpha$ and FSH $\beta$ ). Subunit identity was confirmed by immunological detection and $\mathrm{N}$-terminal amino acid sequencing. Deglycosylation treatment with $\mathrm{N}$-glycosidase F, decreased the molecular mass of both subunits. Intact sbsFSH activated the sea bass FSH receptor stably expressed in the cell line HEK 293, in a dose dependent manner. Purified sbsFSH showed gonadotropic activity, by stimulating the release of estradiol-17 $\beta$ (E2) from sea bass ovary and testosterone (T) and 11-ketotestosterone $(11 \mathrm{KT})$ from testicular tissue cultured in vitro, in a dose and time dependent manner. These results showed that the purified sbsFSH is a heterodimeric hormone, composed of two distinct glycoprotein subunits (GP $\alpha$ and FSH $\beta$ ), and has biological activity judged by its ability to stimulate its receptor in a specific manner and to promote steroid release from gonadal tissue fragments.
\end{abstract}

Keywords: European sea bass, perciform, gonadotropin, FSH, steroidogenesis, reproduction 


\section{Introduction}

The gonadotropins (GTHs), follicle-stimulating hormone (FSH) and luteinizing hormone (LH), produced in the pituitary gland, are essential for the endocrine control of vertebrate reproduction. Together with the also pituitary-derived thyroid stimulating hormone (TSH) and the placental chorionic gonadotropin (CG) that is present only in primate and equine species, they constitute an evolutionarily conserved family of glycoprotein hormones. They are glycosylated heterodimers formed by the non-covalent association of an $\alpha$-subunit, which is common to all members of the family within a species, with distinct $\beta$-subunits that confer hormone specificity (Pierce and Parsons, 1981; Bousfield et al., 1994). Each of the subunits is encoded by single, separate genes (Fiddes and Talmadge, 1984). The dimerization and glycosylation, which occurs in the rough endoplasmic reticulum and Golgi apparatus, are prerequisites for gonadotropins to achieve full biological activity. The FSH and LH are synthesized in the gonadotrope cells of the pituitary (Nozaki et al., 1990; Naito et al., 1993) and transported via the peripheral circulation to the gonads where they regulate steroidogenesis and gametogenesis. Initial biochemical studies of gonadotropins in fish suggested that a single LH-like gonadotropin regulated gametogenesis (Burzawa-Gerard, 1982). In the late 1980's, the presence and structure of two fish gonadotropins, GTH I and GTH II, was firmly established in the chum salmon (Oncorhynchus keta; Suzuki et al., 1988a,b,c,d). Since then, gonadotropins have been isolated and characterized in several fish species (reviewed in Yaron et al., 2003). Moreover, the extended use of molecular biology techniques has resulted in the isolation and characterization of the cDNAs encoding gonadotropin subunits in more than 30 fish species. Structural analyses of their deduced amino acid sequences, together with functional data, undoubtedly indicate that GTH I and GTH II are orthologues of the tetrapod FSH and LH, respectively (Prat et al., 1996; Li and Ford, 1998; Querat et al., 2000).

The physiological functions of both GTHs are well established in higher vertebrates, while those in teleosts are still poorly understood. In salmonids FSH is considered to regulate early phases of gametogenesis, such as vitellogenesis and spermatogenesis, whereas LH is considered to be responsible for the final maturation processes, such as oocyte maturation, ovulation and 
spermiation (Swanson et al., 2003; Yaron and Sivan, 2006). However, the functional duality between FSH and LH has yet to be clarified in perciform fish. During female vitellogenesis in common carp (Van Der Kraak et al., 1992), tuna (Okada et al., 1994), and salmon (Suzuki et al., 1988c; Planas et al., 2000), both FSH and LH stimulate the in vitro production of ovarian estrogens. During male spermatogenesis in salmon (Planas and Swanson, 1995) and red seabream (Kagawa et al., 1998), both LH and FSH stimulate testicular androgen production in vitro. Furthermore, several studies have suggested cross-ligand binding of fish gonadotropin receptors (reviewed in Bogerd et al., 2005). Unfortunately, purified intact FSH is still not available for most teleost species due to the need of a great number of pituitaries and the reduced content of FSH present in them. Hence, the information on its physiological roles is scarce compared with what is known about LH. The European sea bass is a perciform fish, highly valued in aquaculture. In this species, puberty is attained at 2 years of age in males and at 3 years in females and then reproduction is repeated once a year during winter season. The females present a group-synchronous type of ovarian development, producing 3-4 consecutive spawns during the 1-2 months spawning period (Alvariño et al., 1992; Carrillo et al., 1995, Asturiano et al., 2000). In sea bass, the role of FSH in these processes is not well clarified due mainly to the lack of an assay to measure its levels throughout the reproductive cycle. This paper reports the purification and characterization of native sea bass FSH. Its biochemical properties and biological activities were investigated with the aim to acquire a more accurate knowledge regarding the function of FSH in fish reproduction. The presented results provide the basis for future research on the function of FSH in sea bass.

\section{Materials and methods}

\subsection{Pituitary collection and extraction}

Sexually mature male and female sea bass (Dicentrarchus labrax) were obtained from a commercial dealer (Culmarex, Aguilas, Spain). Fish were anesthetized and sacrificed by decapitation in accordance with the European Union Animal Care Regulations. Around 1400 pituitary glands (4.1 g wet weight) were collected and immediately frozen in liquid nitrogen and stored at $-80^{\circ} \mathrm{C}$ until use. 
Pooled pituitaries were homogenized in $25 \mathrm{ml}$ of $10 \%$ ammonium acetate, $\mathrm{pH} 7.5$, containing $1 \mathrm{mM}$ phenylmethylsulfonyl fluoride (PMSF) and $5 \mathrm{mM}$ EDTA, on ice, using a mechanically driven glass Teflon homogenizer. The homogenate was stirred for $1 \mathrm{~h}$ at $4^{\circ} \mathrm{C}$ and centrifuged at $20,000 \mathrm{~g}$ for $30 \mathrm{~min}$ at $4^{\circ} \mathrm{C}$, to eliminate debris. The pellet was re-extracted to recover additional glycoproteins. The supernatant was adjusted to $40 \%$ ethanol (v/v) by slow addition of ice-cold ethanol and stirred overnight at $4^{\circ} \mathrm{C}$. After centrifugation $\left(20,000 \mathrm{~g}\right.$ for $30 \mathrm{~min}$ at $\left.4^{\circ} \mathrm{C}\right)$ the supernatant was adjusted to $85 \%$ ethanol $(\mathrm{v} / \mathrm{v})$, and kept at $4^{\circ} \mathrm{C}$ overnight without stirring. The glycoprotein precipitate was recovered by centrifugation $\left(20,000 \mathrm{~g}\right.$ for $30 \mathrm{~min}$ at $\left.4^{\circ} \mathrm{C}\right)$ and ethanol removed using a vacuum desiccator (10 min).

\subsection{Ion-exchange chromatography}

The moist pellet $\left(80 \mathrm{mg}\right.$ protein) was solubilized ( $3 \mathrm{~h}$ at $4^{\circ} \mathrm{C}$ ) in $20 \mathrm{ml}$ of 50 $\mathrm{mM}$ ammonium bicarbonate, $\mathrm{pH}$ 8.0, and fractionated by weak anion-exchange chromatography, using a high-performance liquid chromatography (HPLC) system, on an LKB Ultropac TSK-DEAE-5PW HPLC column (21.5 x $150 \mathrm{~mm}$; Pharmacia LKB) equilibrated with the same buffer. Adsorbed proteins were eluted with a linear gradient of $50-1000 \mathrm{mM}$ ammonium bicarbonate, $\mathrm{pH}$ 8.0. Fractions of $8 \mathrm{ml}$ were collected at a flow rate of $4 \mathrm{ml} /$ min, and the absorbance read at 280 and $215 \mathrm{~nm}$. Fractions were pooled in eight groups and lyophilized. The molecular mass of the pooled fractions were estimated by mass spectrometry.

\subsection{Reversed-phase chromatography}

Pooled and lyophilized fractions containing proteins with estimated molecular masses similar to those of known GTHs were reconstituted in $2 \mathrm{ml}$ of $50 \mathrm{mM}$ ammonium acetate buffer, $\mathrm{pH}$ 8.0, and further fractionated by reversed-phase chromatography, using a HPLC system (rpHPLC), on a RESOURCE 15RPC 3ml column (6.4 x $100 \mathrm{~mm}, 15 \mu \mathrm{m}$ particle size; GE Healthcare Bio-Sciences AB, Sweden). Proteins were eluted with a linear gradient of $0-50 \%(\mathrm{v} / \mathrm{v})$ acetonitrile in $50 \mathrm{mM}$ ammonium acetate $\mathrm{pH} 8.0$, for $80 \mathrm{~min}$, at a flow rate of $1 \mathrm{ml} / \mathrm{min}$ at room temperature and fractions of 1 $\mathrm{ml}$ were collected. Peaks of protein were screened for GTHs by SDS-PAGE, Western blot, mass spectrometry and $\mathrm{N}$-terminal amino acid sequencing. 


\subsection{Electrophoresis}

Electrophoresis was performed according to Laemmli (1970), on 4\% stacking and $15 \%$ separating polyacrylamide gels (0.1\% SDS), under reducing (5\% 2-Mercaptoethanol (2-ME), $\left.5 \mathrm{~min} 95^{\circ} \mathrm{C}\right)$ and non-reducing conditions. Gels were stained with $0.1 \%$ Coomassie brilliant blue R-250 in a $40 \%$ methanol/10\% acetic acid solution. A prestained SDS-PAGE Standard Broad Range was used as molecular weight marker (Bio-Rad Laboratories, Inc, CA, USA).

\subsection{Western blotting}

Samples were separated by SDS-PAGE as described above. The gel was equilibrated with a blotting buffer containing $25 \mathrm{mM}$ Tris, $192 \mathrm{mM}$ Glycine and 20\% methanol ( $\mathrm{pH} 8.3$ ) and then electrophoretically transferred onto a PVDF membrane (Immobilon P, Millipore Corp.). The membrane was incubated in a blocking buffer (5\% dried milk in $10 \mathrm{mM}$ Tris-base, $150 \mathrm{mM} \mathrm{NaCl}$ and $0.1 \%$ Tween 20 (TBS-T)) overnight at $4^{\circ} \mathrm{C}$ and then immersed for $90 \mathrm{~min}$ at room temperature in a solution containing the specific antisera at a final dilution of 1:3000. The specific antibodies against sea bass GP $\alpha$ (sbsGP $\alpha$ ) and LH $\beta$ (sbsLH $\beta$ ) subunits (Mateos et al., 2006) and against a mummichog FSH $\beta$ (mFSH $\beta$ ) synthetic peptide (Shimizu and Yamashita, 2002) were used as specific antisera. A test with sea bass pituitary homogenate was previously performed to determine the anti-mFSH $\beta$ specificity for sbsFSH $\beta$ and a positive reaction was obtained. The membrane was washed three times with TBS-T solution, and then incubated with 1:2000 goat anti-rabbit IgG horseradish peroxidase conjugate (GAR-HRP, BioRad Laboratories) diluted in the blocking buffer, for $1 \mathrm{~h}$ at room temperature. The membrane was washed again with TBS-T solution and the inmunodetection was performed by chemiluminescence (Western Blotting Luminol Reagent, Santa Cruz Biotechnology, Inc.).

\subsection{Mass spectrometry}

All MALDI-TOF mass spectra were acquired on a BRUKER Ultraflex spectrometer equipped with a pulsed nitrogen laser $(337 \mathrm{~nm})$, in linear, pos- 
itive ion mode, using a $25 \mathrm{kV}$ acceleration voltage. Samples were prepared by mixing equal volumes of a saturated solution of the matrix (sinapinic acid (3, 5-dimethoxy-4-hydroxycinnamic acid)) in $0.1 \%$ trifluoroacetic acid in water/acetonitrile $2: 1$, and a protein solution of a concentration on the range of $1-10 \mu \mathrm{M}$. From this mixture, $0.5 \mu \mathrm{L}$ were spotted on the sample slide and allowed to evaporate to dryness. Once evaporated, samples were washed with $1 \mu \mathrm{L}$ of $0.1 \%$ TFA, which was removed after some seconds by aspiration, and then a further $0.5 \mu \mathrm{L}$ of matrix solution applied. Proteins of known molecular mass were used as standards for mass calibration.

\subsection{N-Terminal amino acid sequencing}

Samples of the purified proteins, containing about $1 \mu \mathrm{g}$ of protein, were adsorbed on a PVDF membrane (Millipore) and washed several times with deionized water. The N-terminal sequence was determined by Edman's automated degradation using a Beckman LF3000 protein sequencer equipped with an on-line PTH-amino acid analyzer System Gold (Beckman, Fullerton, CA, USA). Protein homology searches were performed using the BLAST network service (Altschul et al., 1997).

\subsection{Heterodimer stability test of intact sbsFSH}

To understand the chemical bond of sbsFSH subunits, purified sbsFSH dimers were treated with $0.1 \%$ Trifluoroacetic acid (TFA) or 5\% 2-Mercaptoethanol (2-ME) for $15 \mathrm{~min}$ at $25^{\circ} \mathrm{C}$. They were then separated by SDSPAGE under nonreducing conditions, and the associated states of the respective sbsFSH subunits were analyzed by subsequent Western blotting.

\subsection{Glycosidase treatments}

Based on supplier recommendations (Roche Diagnostics, Mannheim, Germany), $4 \mu \mathrm{g}$ of sbsFSH dimer were denatured for $5 \mathrm{~min}$ at $94^{\circ} \mathrm{C}$ in $0.1 \%$ SDS and $50 \mathrm{mM}$ 2-Mercaptoethanol. Then, it was incubated with 2.5 Units of peptide- $N$-glycosidase F (PNGase F, Roche Diagnostics) for 2 hour at $37^{\circ} \mathrm{C}$ in $20 \mathrm{mM}$ sodium phosphate with 0.5\% NP-40, pH 7.5, which hydrolyzes all types of $N$-glycans chains. Deglycosylated proteins were subjected to SDSPAGE followed by Western blotting analysis. 


\subsection{Activation of FSHR}

The biological activity of the purified hormone was analyzed using two cell lines (HEK 293) stably expressing the sea bass FSH or LH receptors (sbsFSHR and sbsLHR) and the firefly luciferase gene under the control of a promoter with cAMP Responsive Elements (CRE) binding sites (Rocha et al., 2007). Receptor activation by FSH was indirectly measured by recording changes in luciferase activity, promoted by a rise of cAMP. HEK 293 cells stably expressing sbsFSHR were plated in 48-well culture plates at $4.5 \times 10^{5}$ cells/well. For the determination of luciferase activity, cells were incubated with serial dilutions of sbsFSH preparations in Advanced DMEM media (Invitrogen Corp.) containing 100 units/ml Penicillin/Streptomycin, 1\% Glutamine and $100 \mu \mathrm{g} / \mathrm{ml}$ Hygromycin. Recombinant sea bass LH, produced using a Baculovirus Expression System, in Sf9 insect cells (Molés, G., Gómez, A., Carrillo, M., Zanuy, S., unpublished), was used as positive control for stimulation of the sbsLHR cell line. After $5 \mathrm{~h}$ of incubation cells were lysed in Reporter Lysis Buffer (Promega Corp.) as indicated by the manufacturer. Cell debris were separated by centrifugation for $30 \mathrm{~s}$ at $15,000 \mathrm{~g}$, and $20 \mu \mathrm{l}$ of the supernatant were mixed with $100 \mu \mathrm{l}$ luciferin reagent $(20 \mathrm{mM}$ Tricine KOH, pH 7.8, 0.1 mM EDTA, 8 mM MgCl, 33.3 mM DTT, $270 \mu \mathrm{M}$ CoA, $530 \mu \mathrm{M}$ ATP, $400 \mu \mathrm{M}$ luciferin). The light emitted was measured in a luminometer (Junior, EG\&G, Berthold) and expressed as relative light units (RLU).

\subsection{In vitro bioassay}

In vitro tissue cultures of sea bass gonads were performed following the protocol described by Planas et al. (1993) with minor modifications. Briefly, ovaries and testis of adult sea bass sacrificed between July and November were thoroughly chopped on ice with a razor blade until forming a paste. The tissue preparation was washed three times with $10 \mathrm{v} / \mathrm{wt}$ of ice-cold Sea Bass Ringer (SBR; according to Sorbera et al., 1999) containing 0.5\% bovine serum albumin (BSA, Fraction V, Sigma-Aldrich, Inc.) and 100 units/ $\mathrm{ml}$ penicillin/streptomycin (Invitrogen Corp.). After each wash, the supernatant was discarded and fresh media was added again to the preparation, the tube was gently mixed by hand and centrifugated for $10 \mathrm{~min}$ at $60 \mathrm{~g}$ at 
$4^{\circ} \mathrm{C}$. After the last wash, the preparation was filtered through a $750 \mu \mathrm{m}$ (for testis) and $150 \mu \mathrm{m}$ (for ovary) nylon mesh. Pieces of the gonadal preparation were transferred to 24-well plates at about $40 \mathrm{mg}$ per well containing $0.5 \mathrm{ml}$ of SBR. The samples were preincubated in $0.5 \mathrm{ml}$ of SBR for $30 \mathrm{~min}$ at $21^{\circ} \mathrm{C}$ under shaking conditions (100 rpm). After preincubation, the medium was replaced for $0.5 \mathrm{ml}$ of fresh SBR containing different sbsFSH dilutions. Four replicates were used for each treatment and experiments were performed by triplicate. Tissues were then incubated for $20 \mathrm{~h}$ under the same conditions as in the preincubation. After incubation, the medium was collected and centrifuged for $15 \mathrm{~min}$ at $500 \mathrm{~g}$ at $4^{\circ} \mathrm{C}$ and the supernatant was stored at $-20^{\circ} \mathrm{C}$ until steroid analysis.

\subsection{Steroids measurements}

Estradiol (E2) was measured by a conventional competitive enzymelinked immunosorbent assay (ELISA), developed and validated for the sea bass in our laboratory (Crespo, B., Navas, J.M., Rocha, A., Zanuy, S., Carrillo, M., unpublished). The assay uses specific rabbit antisera against E2 as primary antibody and estradiol acetylcholinesterase conjugate (E-AChE, Cayman Chemical MI, USA) as tracer. The specific rabbit anti-E2 used is the same employed in the E2 RIA described by Prat et al. (1990), where details on cross reactivity of this antibody to other steroids are given. The separation between free and bound fractions of tracer is achieved by coating the plates with mouse anti-rabbit IgG monoclonal antibody (Clone RG-16, Sigma-Aldrich, Inc). Culture medium was extracted with methanol (Panreac Química S.A., Spain). The organic solvent was evaporated and the dry extract was reconstituted in assay buffer (EIA buffer, Cayman Chemical MI, USA) by vortexing. The assay was performed in a final volume of $150 \mu \mathrm{l}$ in mouse anti-rabbit IgG coated wells (200 $\mu \mathrm{l}$ of a 1:1800 dilution/well; 96 -well microtiter plates). Each component, E-AChE tracer (diluted to 1:10 Ellman Units (E.U.)/ml), anti-E rabbit antiserum (diluted to 1:845,000), E standards (ranging from $80 \mathrm{ng} / \mathrm{ml}$ to $0.039 \mathrm{ng} / \mathrm{ml}$ ), or samples, were added in a volume of $50 \mu \mathrm{l}$. Plates were incubated overnight at $37^{\circ} \mathrm{C}$. After incubation, plates were rinsed and $200 \mu \mathrm{l}$ of Ellman's reagent were added to each well. Colour development was performed at $20^{\circ} \mathrm{C}$ in the dark under constant gentle agitation for $2 \mathrm{~h}$. Optical density was read at $405 \mathrm{~nm}$ using a microplate reader 
(Bio-Rad microplate reader model 3550). The sensitivity of the assay was around $0.156 \mathrm{ng} / \mathrm{ml}$ and half-displacement $(\mathrm{Bi} / \mathrm{B} 0=50 \%)$ occurred around $1.90 \mathrm{ng} / \mathrm{ml}$.

The levels of 11-ketotestosterone (11-KT) were determined by enzyme immunoassay (EIA), using an assay developed for the Siberian sturgeon and modified for its use in sea bass (Rodriguez et. al, 2005). The protocol was similar to that described by Cuisset et al. (1994) except that primary antibodies were used at a final dilution of 1:200,000 and the tracer (Cayman Chemicals, MI, USA) was diluted at 1:10 E.U. /ml. The assay sensitivity of 11-KT was $1.75 \mathrm{pg} /$ well. Culture medium testosterone $(\mathrm{T})$ levels were determined by a specific EIA developed by Rodríguez et al. (2000) for sea bass.

\section{Results}

\subsection{Isolation and purification of intact sbsFSH}

The pituitary ethanol-extracted glycoproteins were subjected to separation by anion-exchange chromatography (Fig. 1). The collected fractions were analyzed by mass spectrometry and based on molecular weight data

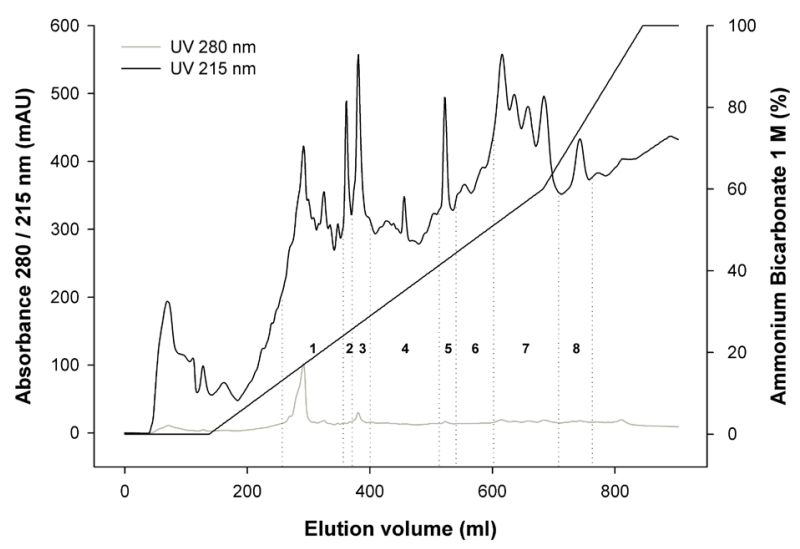

Figure 1. Anion-exchange chromatography on a LKB Ultropac TSK-DEAE column $(21.5 \times 150$ $\mathrm{mm}$ ) of the ethanol extract from sea bass pituitaries. Adsorbed proteins were eluted with a linear gradient of 50-1000 mM ammonium bicarbonate (line), $\mathrm{pH}$ 8.0. Fractions of $8 \mathrm{ml}$ were collected at a flow rate of $4 \mathrm{ml} / \mathrm{min}$, and the absorbance read at 280 and $215 \mathrm{~nm}$. Fractions were pooled in 8 groups as indicated. 

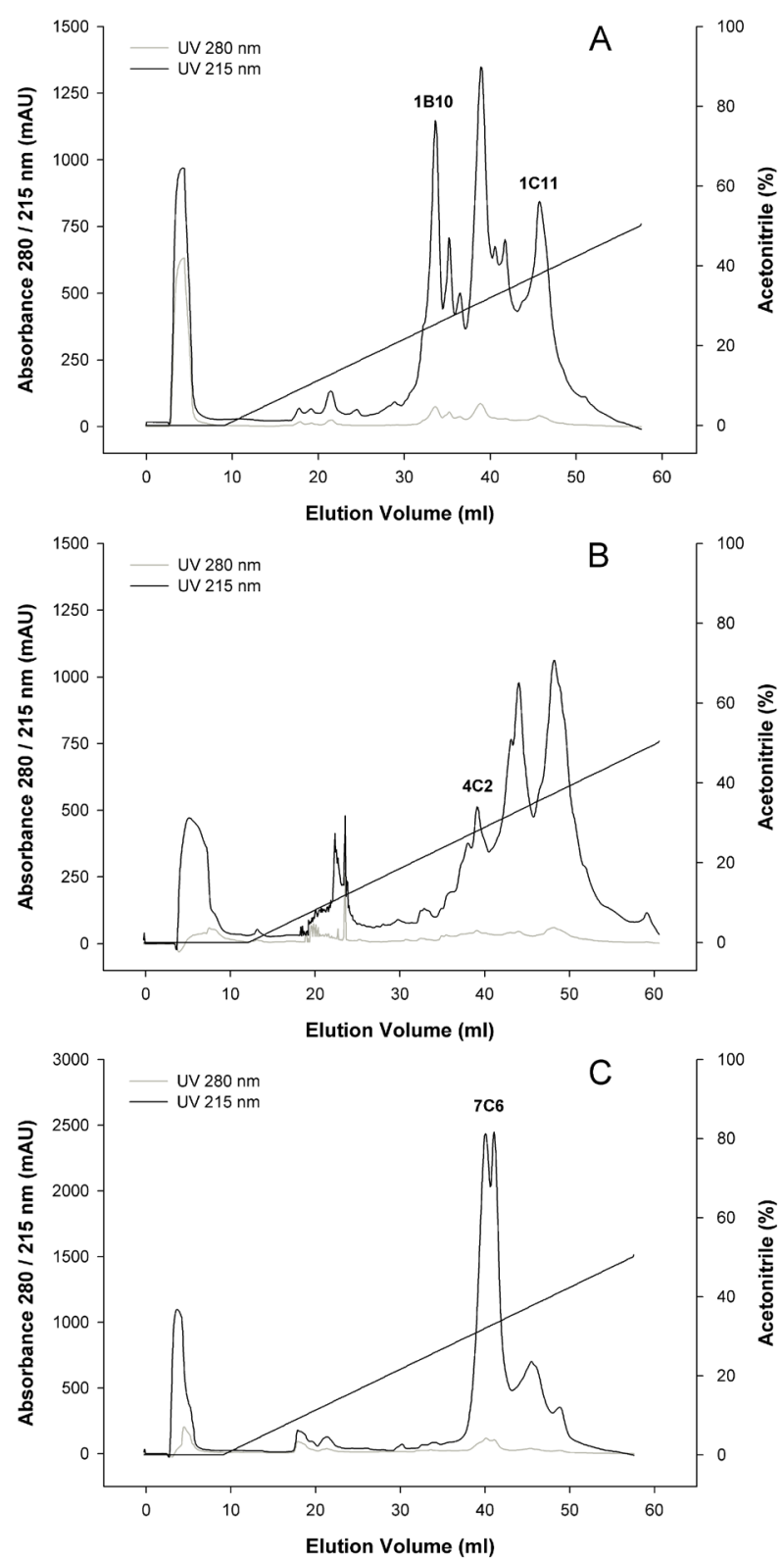

Figure 2. Reverse-phase chromatography on a RESOURCE 15RPC column $(6.4$ x $100 \mathrm{~mm}, 15$ $\mu \mathrm{m}$ particle size) of pools 1 (A), 4 (B) and 7 (C) from anion-exchange chromatography (Fig. 1), using a HPLC system. Proteins were eluted with a linear gradient of acetonitrile $(0-50 \%)$ in $50 \mathrm{mM}$ ammonium acetate (line), $\mathrm{pH} 8.0$, and a flow rate of $1 \mathrm{ml} / \mathrm{min}, 1 \mathrm{ml} /$ tube, at room temperature. After $\mathrm{N}$-terminal amino acid sequencing and Western blotting peaks were identified as sbsFSH (1B10), sbsGP $\alpha$ (1C11), sbsFSH $\beta$ (4C2) and sbsLH $\beta$ (7C6). 
they were pooled in eight groups and lyophilized. The resulting groups were further fractionated by reverse phase chromatography and the eluted fractions were analyzed by Western blotting, mass spectrometry and finally by $\mathrm{N}$-terminal amino acid sequencing, in search of putative intact FSH and its subunits. Results from mass spectrometry and Western blotting revealed that fraction $1 \mathrm{~B} 10$ (Fig. 2A), contained a highly purified protein reacting with both anti-sbsGP $\alpha$ and anti-mFSH $\beta$ but not with anti-sbsLH $\beta$ (Fig. 4). The molecular mass of this protein was $28.5 \mathrm{KDa}$ (Fig. $3 \mathrm{~A}$ ) and N-terminal amino acid sequencing revealed that it corresponds to the predicted amino acid sequences of sea bass GP $\alpha$ and FSH $\beta$ subunits, respectively (Fig. 5). These results indicated that fraction $1 \mathrm{~B} 10$ contained highly purified sbsFSH with a yield of $170 \mu \mathrm{g}$ of protein.

Analysis of three other fractions (1C11, 4C2 and 7C6) showed that they contained different quantities of purified sea bass GP $\alpha$, FSH $\beta$ and LH $\beta$ subunits, respectively (Fig. 2). Their identities were also confirmed by Western blot (Fig. 4) and N-terminal amino acid sequencing (Fig. 5) and their molecular masses were 12.6 KDa, 13.6 KDa and 15.3 KDa respectively (Fig. 3).
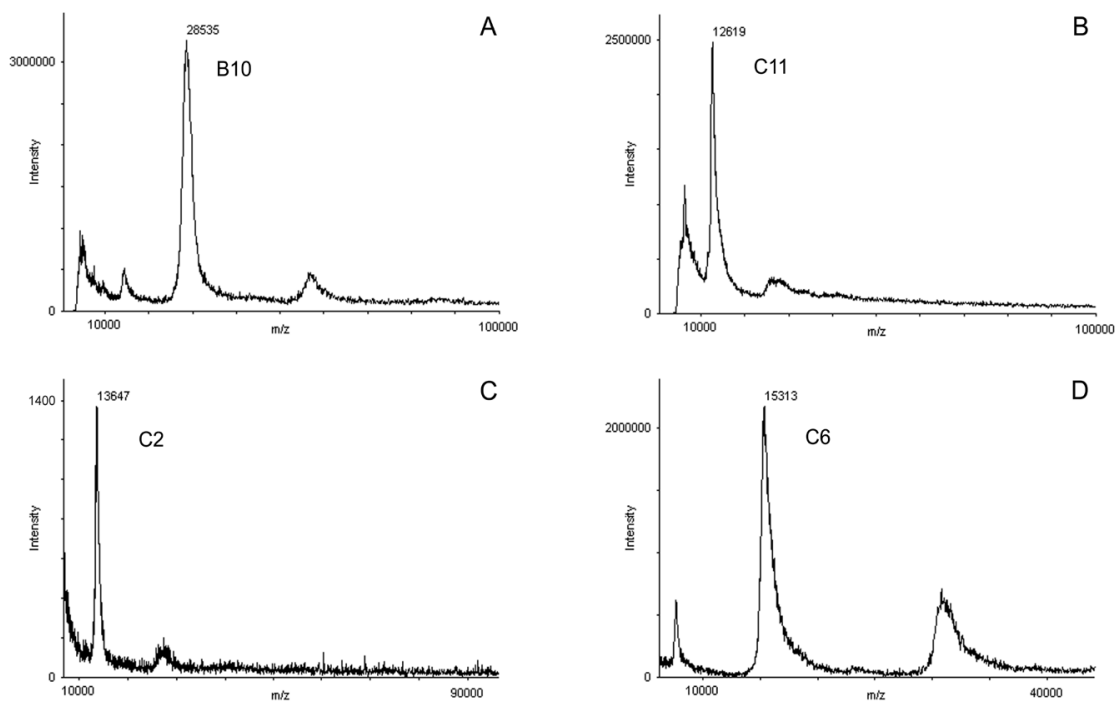

Figure 3. Mass spectrometry of fractions obtained from reverse phase chromatography. (A) sbsFSH (1B10), (B) sbsGP $\alpha$ (1C11), (C) sbsFSH $\beta$ (4C2) and (D) sbsLH $\beta$ (7C6). MALDITOF mass spectra were acquired on a BRUKER ultraflex spectrometer, with a pulsed nitrogen laser (337 $\mathrm{nm}$ ), in linear positive ion mode, using a $25 \mathrm{kV}$ acceleration voltage. 


\subsection{Biochemical and immunological properties of sbsFSH and its subunits}

When subjected to SDS-PAGE under non-reducing conditions, the purified sbsFSH (1B10) appeared as a unique band, whereas under reducing conditions two distinct proteins of smaller molecular weight could be visualized (Fig. 4). In the Western blotting analysis, the anti-mFSH $\beta$ specifically reacted to the smaller band and the anti-sbsGP $\alpha$ with the bigger band (Fig. $4 \mathrm{~B}$ and $\mathrm{C}$ ). Under non-reducing conditions, the anti-mFSH $\beta$ did not react with the sbsFSH dimer due to epitope masking and only when the antigen was reduced the detection was possible (Fig. 4B).

Deglycosylation treatment of the purified FSH with $\mathrm{N}$-glycosidase F decreased the molecular mass of both subunits making them equal in size (Fig. 4A). In addition, both anti-sbsGP $\alpha$ and anti-mFSH $\beta$ reacted with bands almost equal in size (Fig. $4 \mathrm{~B}$ and $\mathrm{C}$ ). Considering that the deduced amino acid sequences of the cDNAs encoding the mature sea bass GP $\alpha$ and FSH $\beta$ have

A
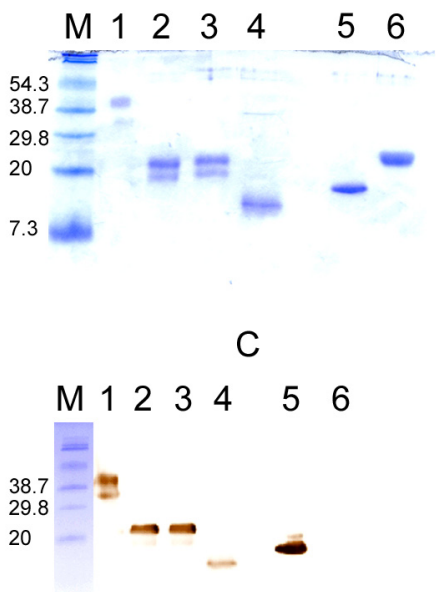

B

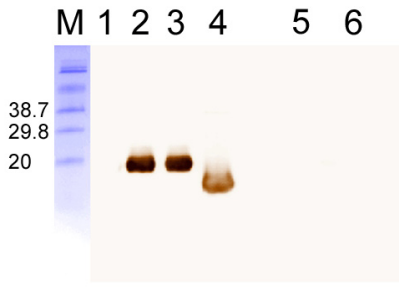

D

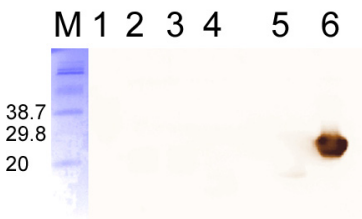

Figure 4. SDS-PAGE and Western blotting of purified sbsFSH (1B10), sbsGPa (1C11) and $\operatorname{sbsLH} \beta$ (7C6). Electrophoresis was carried out with 3-4 $\mu \mathrm{g}$ of protein sample on $15 \%$ SDSPAGE gels. (A) Proteins stained with Coomassie blue. (B) Western blotting with anti-mFSH $\beta$. (C) Western blotting with anti-sbsGP $\alpha$. (D) Western blotting with antisbsLH $\beta$. Lane 1: sbsFSH without reduction; Lane 2: sbsFSH treated with $0.1 \%$ TFA, 15 min at $25^{\circ} \mathrm{C}$; Lane 3: sbsFSH reduced with 5\% 2-ME; Lane 4: Deglycosylation of sbsFSH with $2.5 \mathrm{U}$ of PNGase F and reduced with 5\% 2-ME; Lane 5: sbsGP $\alpha$ reduced with 5\% 2-ME; Lane 6: sbsLH $\beta$ reduced with 5\% 2-ME. M: BioRad prestained SDS-PAGE Broad Range molecular weight marker. 

A) GP- $\alpha$ :
$-1 \quad 1$
$-5$
D Y
1B10 :

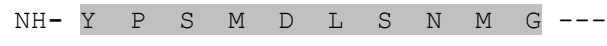
1C11:
$\begin{array}{lllllllllllllll} & N H- & Y & P & S & M & D & L & S & N & M & G & ---\end{array}$
$\begin{array}{lllll}-5 & -1 & 1 & 14\end{array}$
B) FSH $\beta$ :
1B10:
4C2:

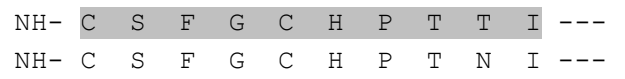
C) $\operatorname{LH} \beta$ :

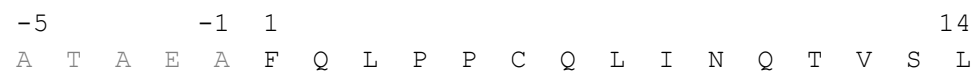
7C6:

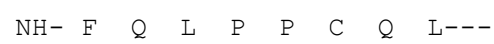

Figure 5. N-terminal amino acid sequence of purified sbsFSH (1B10), sbsGP $\alpha$ (1C11), sbsFSH $\beta$ $(4 \mathrm{C} 2)$ and sbsLH $\beta$ (7C6). Alignment with those predicted from sea bass gonadotropin cDNA sequences.

almost the same number of residues (94 and 105 amino acids, respectively), these results clearly show that both subunits decreased their molecular mass by deglycosylation treatment and therefore they are $N$-glycosylated.

The stability of the purified sbsFSH heterodimer was tested under acidic and reducing conditions using TFA and 2-ME, respectively. In both cases intact sbsFSH was dissociated into its respective subunits (Fig. 4).

The purified sbsGP $\alpha(1 \mathrm{C} 11)$ and sbsLH $\beta$ (7C6) subunits reacted strongly with anti-sbsGP $\alpha$ and anti-sbsLH $\beta$, respectively (Fig.4 C and D). However the purified sbsGP $\alpha(1 \mathrm{C} 11)$ showed a smaller size when compared with the sbsGP $\alpha$ of the dimer (1B10), probably due to differences in the degree of glycosylation or a degradation phenomenon during the process of purification.

\subsection{Bioactivities of the purified native sbsFSH}

The bioactivity and specificity of the purified sbsFSH was analyzed by determining its capacity to stimulate intracellular cAMP production in HEK 293 cells stably expressing the sbsFSHR or the sbsLHR, as well as its capacity to stimulate steroid production by gonadal tissue fragments cultured in vitro. Purified sbsFSH was able to activate the sbsFSHR in a dose depend- 

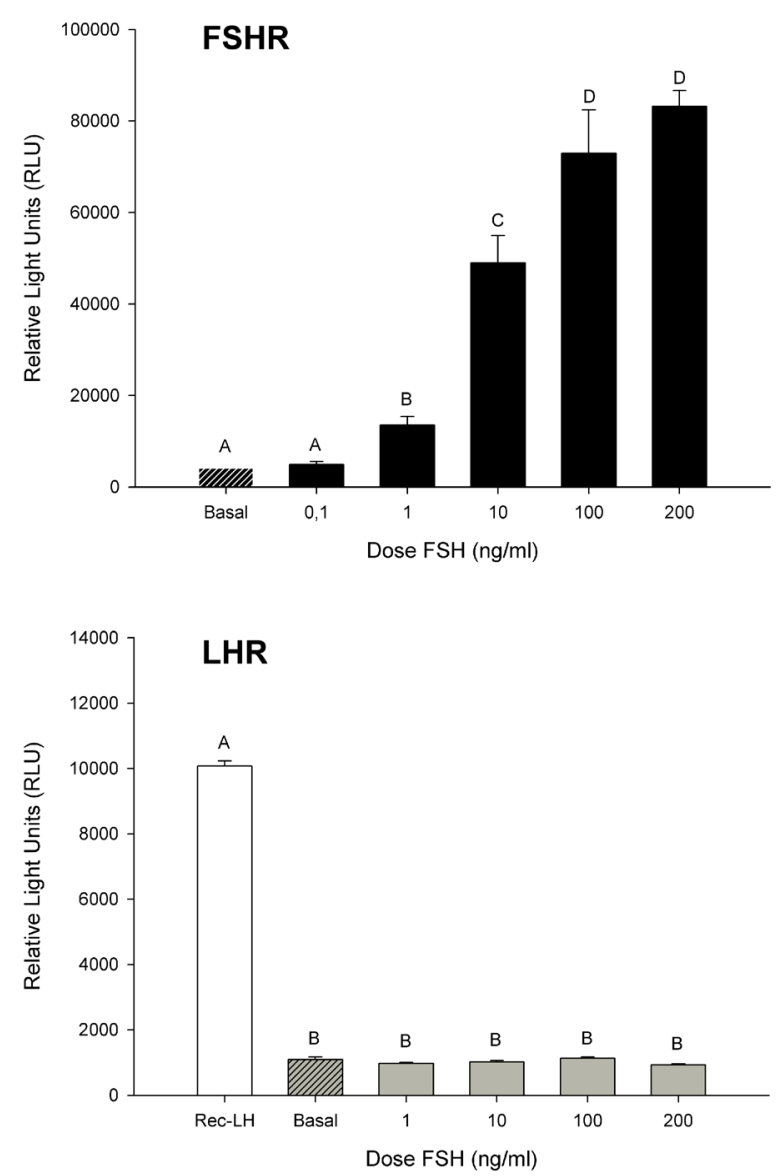

Figure 6. Activation of sea bass FSH and LH receptors with purified sbsFSH. HEK293 cells stably expressing the sbsFSHR or the sbsLHR were treated with increasing concentrations of purified sbsFSH (1B10). Luciferase activity after 5-h treatment of the sbsFSHR or the sbsLHR with different doses of sbsFSH. Recombinant sea bass LH was used as positive control.

ent manner and was unable to stimulate the sbsLHR, exhibiting specificity for its receptor (Fig. 6). Effects of purified sbsFSH on E2 secretion by adult sea bass ovary was analyzed during the previtellogenic (July-August), early vitellogenic (October) and mid vitellogenic (November) stages and showed, a clear dose-dependent effect on E2 secretion from August to November, with a minimal significant $(p<0.01)$ effective concentration of $10 \mathrm{ng} / \mathrm{ml}$ in October (Fig. 7B). The stimulatory effects of sbsFSH were also found to be 
time-dependent since sbsFSH $(100 \mathrm{ng} / \mathrm{ml})$ significantly $(p<0.001)$ stimulated E2 secretion from 2 to 20 hours of incubation (Fig. 7A). In adult sea bass testis, the stimulating effects of sbsFSH were analyzed by measuring $\mathrm{T}$ and 11-KT secretion from September to November, which includes from early recrudescence to early spermiogenesis. The analysis showed a dose-dependent tendency on $\mathrm{T}$ and 11-KT secretion, although less pronounced than the
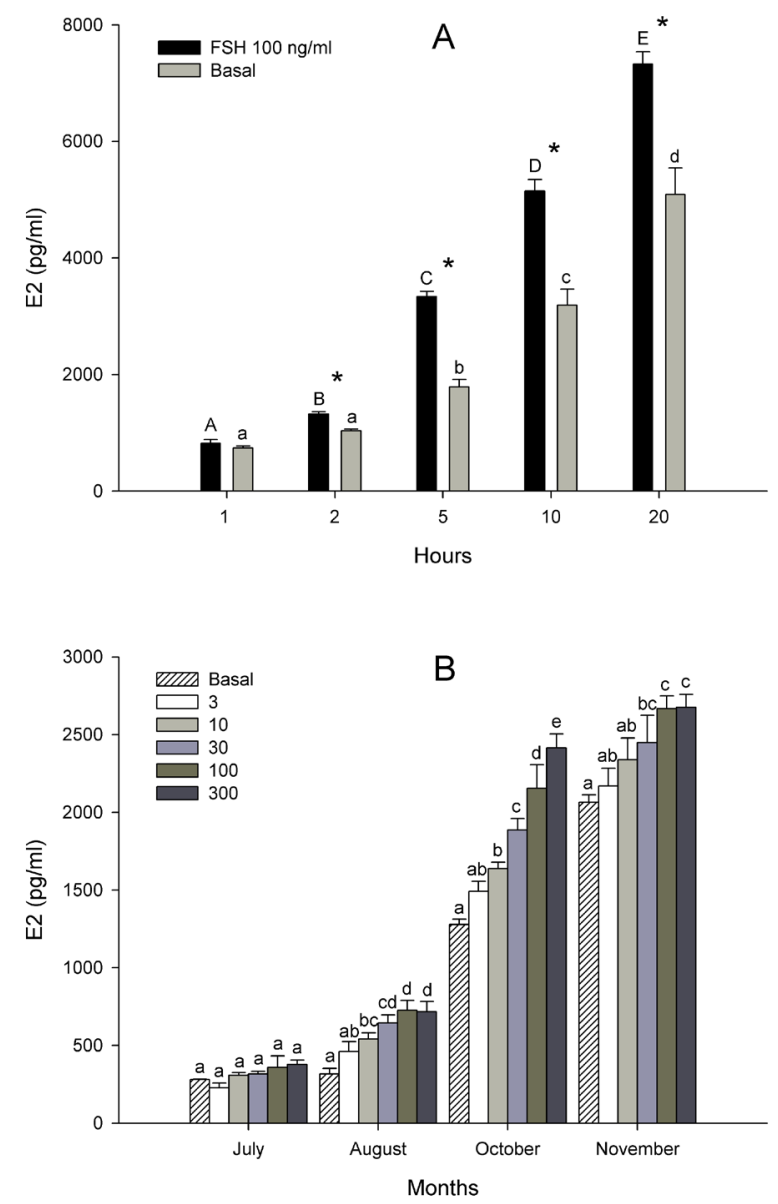

Figure 7. In vitro effects of purified sbsFSH (1B10) on E2 production by sea bass ovary. Tissue fragments ( $40 \mathrm{mg} /$ well) were incubated with $0.5 \mathrm{ml}$ of control medium (basal) or medium containing different concentrations of sbsFSH. Data are expressed as means \pm SEM. (A) Temporal E2 production in response to $100 \mathrm{ng} / \mathrm{ml}$ of sbsFSH. Different letters indicate significant differences between hours $(p<0.001)$. Asterisks represent significant differences from the basal $(p$ $<0.001)$. (B) E2 production after $20 \mathrm{~h}$ of incubation with different doses of sbsFSH (3-300 ng/ $\mathrm{ml})$. Different letters indicate significant differences between doses $(p<0.05)$. 

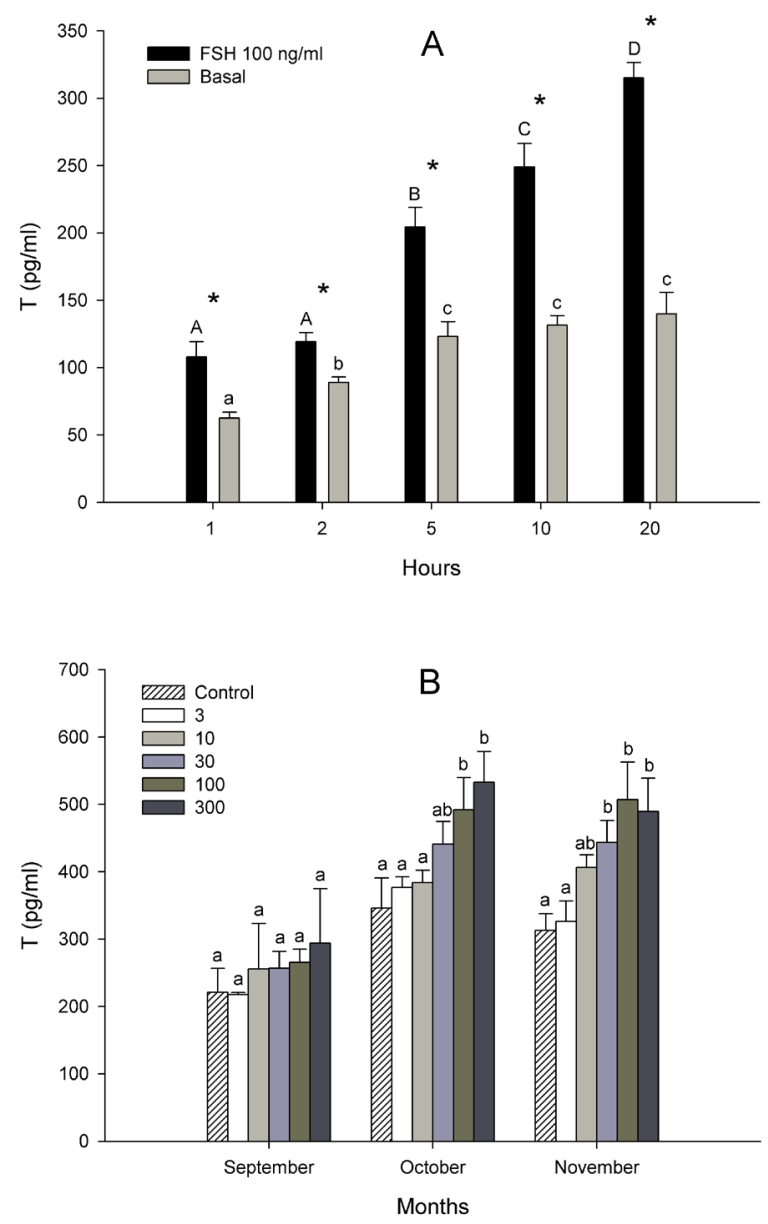

Figure 8. In vitro effects of purified sbsFSH (1B10) on T production by sea bass testis. Tissue fragments $(40 \mathrm{mg} /$ well) were incubated with $0.5 \mathrm{ml}$ of control medium (basal) or medium containing different concentrations of sbsFSH. Data are expressed as means \pm SEM. (A) Temporal $\mathrm{T}$ production in response to $100 \mathrm{ng} / \mathrm{ml}$ of FSH. Different letters indicate significant differences between hours $(p<0.03)$. Asterisks represent significant differences from the basal $(p<0.03)$. (B) $\mathrm{T}$ production after $20 \mathrm{~h}$ of incubation with different doses of sbsFSH $(3-300 \mathrm{ng} / \mathrm{ml})$. Different letters indicate significant differences between doses $(p<0.03)$.

E2 secretion seen in the ovary. The minimal significant $(p<0.05)$ effective concentration of sbsFSH capable of stimulating the in vitro production of $\mathrm{T}$ and 11-KT, was $30 \mathrm{ng} / \mathrm{ml}$ in November (Fig. $8 \mathrm{~B}$ and $9 \mathrm{~B}$ ). The stimulatory effects of sbsFSH on $\mathrm{T}$ and 11-KT secretion were also found to be timedependent since sbsFSH $(100 \mathrm{ng} / \mathrm{ml})$ significantly $(p<0.05)$ stimulated the 

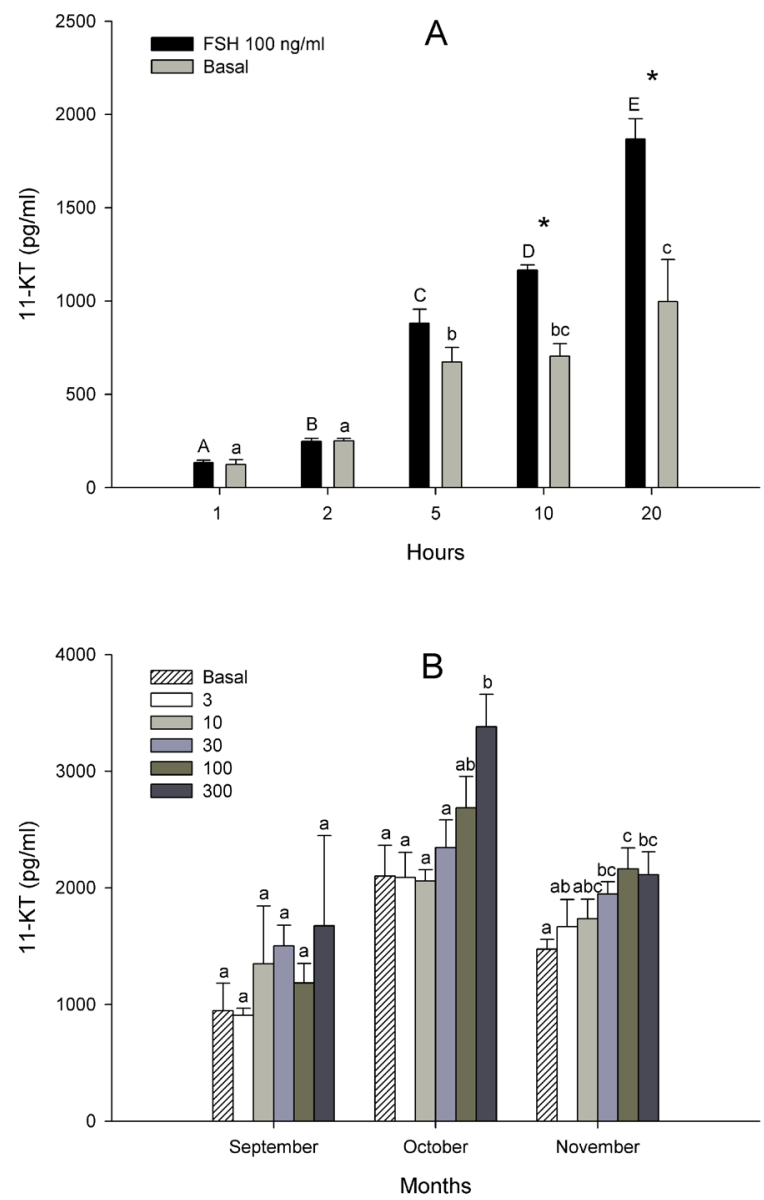

Figure 9. In vitro effects of purified sbsFSH (1B10) on $11 \mathrm{KT}$ production by sea bass testis. Tissue fragments ( $40 \mathrm{mg} /$ well) were incubated with $0.5 \mathrm{ml}$ of control medium (basal) or medium containing different concentrations of sbsFSH. Data are expressed as means \pm SEM. (A) Temporal $11 \mathrm{KT}$ production in response to $100 \mathrm{ng} / \mathrm{ml}$ of sbsFSH. Different letters indicate significant differences between hours $(p<0.05)$. Asterisks represent significant differences from the basal $(p<0.03)$. (B) $11 \mathrm{KT}$ production after $20 \mathrm{~h}$ of incubation with different doses of sbsFSH $(3-300 \mathrm{ng} / \mathrm{ml})$. Different letters indicate significant differences between doses $(p<0.05)$.

secretion of $\mathrm{T}$ from $1 \mathrm{~h}$ until $20 \mathrm{~h}$ of incubation and from $10 \mathrm{~h}$ until $20 \mathrm{~h}$ for 11-KT (Fig. 8A and 9A). 


\section{Discussion}

This study describes the purification and characterization of native intact sea bass FSH, free from LH contamination, from the pituitary glands of mature sea bass. Traditionally, the protocols used in the purification of teleost GTH dimers included a combination of gel filtration and ion-exchange chromatography (Suzuki et al., 1988a; Swanson et al., 1991; Van der Kraak et al., 1992; Copeland and Thomas, 1993; Tanaka et al., 1993; Mañanós et al., 1997; Santos et al., 2001; Kamei et al., 2005). Nevertheless, alternative protocols using ion-exchange and reverse phase chromatography under neutral or slightly basic conditions have been described for the purification of FSH and LH from other teleost species including the bonito (Koide et al., 1993), tuna (Okada et al., 1994), Mediterranean yellowtail (GarcíaHernández et al., 1997) and Atlantic halibut (Weltzien et al., 2003). In this study we used anion-exchange and reverse phase chromatography under slightly basic conditions and it turned out to be particularly effective for the isolation of sbsFSH. However, this protocol might not be suitable for the purification of LH since, as it has been previously described, problems such as low yield or subunit dissociation might occur (Okada et al., 1994). As seen in other species, sbsLH could be considered to be less stable than sbsFSH, since after rpHPLC only small amounts of sbsLH dimer were found while a large amount of its subunits was obtained. It has been described that the amino acid sequence of fish FSH $\beta$ subunits is more variable than that of fish LH $\beta$ subunits even in regions important for heterodimer formation and receptor interactions, such as the "seatbelt" region. The variation in structure among fish FSH $\beta$ subunits in this region may result in species differences in the nature of receptor interactions and possibly stability of the heterodimer (Swanson et al., 2003), which might explain the existence of very stable forms of teleost FSH.

Intact sbsFSH eluted mainly when the linear gradient achieved the 170 $\mathrm{mM}$ ammonium bicarbonate on the ion-exchange column, which is comparable to the $200 \mathrm{mM}$ observed for coho salmon (Swanson et al., 1991), bonito (Koide et al., 1993), Mediterranean yellowtail (García-Hernández et al., 1997), and Atlantic halibut (Weltzien et al., 2003). In contrast, FSH from tuna (Okada et al., 1994) eluted with $300 \mathrm{mM}$ ammonium bicarbonate, which indicates that it has a higher negative charge. 
On the rpHPLC column under basic conditions, the sbsFSH eluted at 25\% acetonitrile, similar to what was observed for Atlantic halibut (Weltzien et al., 2003) and tuna (Okada et al., 1994), while sea bass subunits eluted at 39\% $(\operatorname{sbsGP} \alpha), 28 \%(\operatorname{sbsFSH} \beta)$ and 33\% (sbsLH $\beta$ ) acetonitrile. In other species, as the Mediterranean Yellowtail (García-Hernández et al., 1997) and bonito (Koide et al., 1993), the FSH eluted at minor acetonitrile concentrations (aprox. 15\%). In general, the observed differences in the eluting conditions could be due to a different glycosylation degree, which could change the polarity and net charge of the set and hence, the chromatographic mobility of the protein.

The molecular weight estimates for the purified sbsFSH and its subunits were smaller than for other species of teleost. There is a great variability in the molecular weight of those reported so far, finding subunits that range from 15 to $28 \mathrm{KDa}$ and intact FSH from 32 to $50 \mathrm{KDa}$ (Suzuki et al., 1988a; Swanson et al., 1991; Van der Kraak et al., 1992; Koide et al., 1993; Tanaka et al., 1993; Copeland and Thomas, 1993; Okada et al., 1994; García-Hernández et al., 1997; Govoroun et al., 1997; Mañanós et al., 1997; Shimizu and Yamashita, 2002; Weltzien et al., 2003; Kamei et al., 2005). According to the predicted amino acid sequences, the contribution of the polypeptide backbone to the molecular weight is similar among different teleost species, therefore the different molecular weight estimates could be due to differences in the glycosylation degree of the subunits or a consequence of the method of mass determination employed. For example, in the estimation by SDS-PAGE, the lack of SDS binding to the carbohydrate moieties of glycoproteins leads to lower charge-to-mass ratios for SDS-glycoprotein complexes, resulting in slower mobilities in the gel and therefore the over-estimation of molecular weights by SDS-PAGE. However, the mass spectrometry is a technology that makes possible to measure the molecular weight of any protein with a high accuracy.

Additional sureness for the identity and purity of the sbsFSH was confirmed by $\mathrm{N}$-terminal amino acid sequencing of its subunits. The obtained results were compared to the deduced sequences of sea bass subunit cDNAs (Mateos et al., 2003) confirming that the $1 \mathrm{~B} 10$ fraction contained highly purified hormone composed of sbsGP $\alpha$ and sbsFSH $\beta$ subunits. Moreover, the immunobloting also revealed that the mentioned fraction reacted only with anti-sbsGP $\alpha$ and anti-mFSH $\beta$ and not with anti-sbsLH $\beta$.

On other hand, the deglycosylation treatment with PNGase F revealed 
that both sbsFSH subunits are $N$-glycosylated. This is consistent with previous predictions of N-linked glycosylation sites from deduced amino acid sequences of sbsGP $\alpha$ and sbsFSH $\beta$ subunits (Mateos et al., 2003).

Detailed analysis of the isolated sbsFSH $\beta$, both forming the dimer (1B10) and the subunit alone (4C2), showed a $\mathrm{N}$-terminus, which, compared to that of other species, seems to lack the first three residues (Gly-Gln-Gly). Nevertheless, the amino acid sequence deduced from the cDNA sequence (Mateos et al., 2003) is equal in these positions to other teleosts (Fig. 5). It has been reported that $\mathrm{N}$-terminal heterogeneity is normally observed in FSH $\beta$ subunits, whereas the $\mathrm{N}$-terminus of the LH $\beta$ subunit is usually intact, suggesting that the $\mathrm{N}$-terminus of FSH $\beta$ could be more susceptible to proteolytic degradation during the purification process (Okada et al., 1994). In this study only FSH $\beta$ missing the first three residues of the $\mathrm{N}$-terminus, as in Atlantic halibut (Weltzien et al., 2003), was identified, making difficult to determine whether this sequence corresponds to the true $\mathrm{N}$-terminal region of the mature sbsFSH $\beta$ or it is rather the result of a degradation process during the purification.

In some teleosts such as chum salmon, coho salmon and Mediterranean yellowtail, it is accepted the existence of two types of FSH that are chemically different: one acid-stable type and another acid-unstable type (Suzuki et al., 1988b; Swanson et al., 1991; García-Hernández et al., 1997). This unusual stability to acid treatment could suggest that its subunits are linked by disulfide bonds (Suzuki et al., 1988b). In this study, sbsFSH did not remain stable when subjected to a $0.1 \%$ TFA treatment, which is consistent with a non-covalent type of association between sbsGP $\alpha$ and sbsFSH $\beta$ subunits.

During the purification process, two types of sbsGPa with a different molecular weight were identified. The sbsGP $\alpha$ of the sbsFSH dimer (1B10) has a larger size than the isolated sbsGPa subunit (1C11). Different forms of GP $\alpha$ have also been found in other species of teleosts such as the Mediterranean yellowtail (García-Hernández et al., 1997), the Japanese eel (Kamei et al., 2005), the chum salmon (Suzuki et al., 1988b) and the coho salmon (Swanson et al., 1991). In some cases, they even showed different amino acid composition (Suzuki et al., 1988b; Swanson et al., 1991). In general, these differences in size could be due to a degradation process during the purification or to different carbohydrate composition. SbsGPo is predicted to have two $\mathrm{N}$-glycosylation sites (Mateos et al., 2003). Addition of sugar chains to only one or to both potential sites of glycosylation would originate proteins 
with different molecular weights, which would explain the observed SDSPAGE results. Furthermore, glycosylation of mammalian GP $\alpha$ subunits is known to be required for heterodimer stability (Boime and Ben-Menahem, 1999). This could explain why the larger sbsGPa (1B10), a molecule potentially more glycosylated, was found in the sbsFSH dimer while the smaller form (1C11) was found free.

The biological activity and specificity of the purified sbsFSH were studied by evaluating its ability to stimulate sea bass gonadotropin receptors. In mammals, the specificity barriers between each gonadotropin-receptor couple are such that no cross-signaling occurs under physiological conditions in which hormone concentrations are low (Braun et al., 1991; Moyle et al., 1994). In contrast, there is evidence indicating that the specificity of the piscine gonadotropin receptors is less obvious (Bogerd et al., 2005).

In this study, we demonstrate that the purified sbsFSH is a biologically active protein since it was able to activate the sbsFSHR in a dose dependent manner. In addition, we provide evidence for specific interaction between this hormone and its cognate receptor since the purified sbsFSH was unable to activate the sbsLHR even when high doses were used (200 ng/ml). These results are in accordance with previous results regarding sea bass gonadotropin receptors ligand binding specificity (Rocha et al., 2007).

The steroidogenic activity of the purified sbsFSH was also evaluated by using an in vitro culture system for gonadal tissue. Purified sbsFSH significantly stimulated the release of $\mathrm{T}$ and 11-KT from adult sea bass testes and E2 from ovary fragments in a dose and time dependent manner. This steroid stimulation was greater in testis from males in early recrudescence (October) and in females in early and mid vitellogenic stages (October and November). $\mathrm{T}$ and 11-KT are the major androgens produced in male fish (Borg, 1994) and are known to be essential for spermatogenesis and spermiation (Fostier et al., 1983; Schulz and Miura, 2002). Besides, in Japanese eel it has been recently suggested that $11-\mathrm{KT}$, regulated by $\mathrm{FSH}$, is the key endocrine factor for the initiation of spermatogonial proliferation (Ohta et al., 2007). Also, several reports have demonstrated that the entire process of vitellogenesis is regulated by E2 (Nagahama, 1994) and it has been described the stimulatory effect of FSH on the activity and expression of P-450 aromatase in vitellogenic trout follicles, suggesting that FSH plays a fundamental role in the regulation of E2 production in salmonid ovary (Montserrat et al., 2004). In the sea bass, plasma levels of 11-KT and $\mathrm{T}$ increase during the 
spermatogenesis period (October-January) (Prat et al., 1990; Rodriguez et al., 2004) and plasma levels of E2 increase in parallel with the vitellogenin and the oocyte growth (Asturiano et al., 2000; 2002). The results obtained in this study are consistent with the expression profile seen for sbsFSHR in testis and ovary of adult sea bass, since high levels of sbsFSHR mRNA were observed in October in males and a significant increase in the expression of this gene was appreciated in October-November in females. In both sexes, the highest levels of sbsFSHR expression appear before those of sbsLHR (Rocha, A., Zanuy, S., Carrillo, M., Gómez, A., unpublished). All together, these data support the idea that in sea bass, as in salmonids, the FSH could be acting in the early stages of gametogenesis by promoting the synthesis of sexual steroids and consequently inducing spermatogonial proliferation in males and vitellogenesis in females.

In conclusion, highly purified and biologically active intact FSH, and their free GP $\alpha$ and FSH $\beta$ subunits were isolated from sea bass pituitary glands. The availability of purified sbsFSH will enable to study and understand the mechanisms involved in the gametogenesis process of this species.

\section{Acknowledgments}

We thank to Dr. A. Shimizu from National Research Institute of Fisheries Science, Yokohama (Japan), for supplying the antisera against a synthetic peptide of mummichog FSH $\beta$ subunit. To Dr. F. Canals (Institut de Biotecnologia i Biomedicina, UAB) for his technical assistance in the chromatographic methods. To Dr. J.V. Planas (Facultat de Biologia, UB) for the help in gonadal tissue culture. To S. Ibañez and J. Beltran (IATS) for their help in the steroid EIAs.

Research supported by EU Project PROBASS Q5RS-2000-31365 and Spanish MEC grants AGL2002-10024E and AGL2005-00796. G.M. was supported by Research Fellowship I3P of CSIC.

\section{References}

Alvariño, J.M.R., Carrillo, M., Zanuy, S., Prat, F., Mañanos, E., 1992. Pattern of sea bass oocyte development after ovarian stimulation by LHRHa. J. Fish Biol. 41, 965-970.

Asturiano, J.F., Sorbera, L.A., Ramos, J., Kime, D.E., Carrilo, M., Zanuy, S., 2000. Hormonal regulation of the European sea bass reproductive cycle: an individualized female approach. J. Fish Biol. 56, 1155-1172. 
Asturiano, J.F., Sorbera, L.A., Ramos, J., Kime, D.E., Carrillo, M., Zanuy, S., 2002. Groupsynchronous ovarian development, ovulation and spermiation in the European sea bass (Dicentrarchus labrax L.) could be regulated by shifts in gonadal steroidogenesis. Sci. Mar. 66, 273-282.

Altschul, S.F., Madden, T.L., Schaffer, A.A., Zhang, J., Zhang, Z., Miller, W., Lipman, D.J., 1997. Gapped BLAST and PSI-BLAST: a new generation of protein database search programs. Nucleic Acids Res. 25, 3389-3402.

Bogerd, J., Granneman, J.C., Schulz, R.W., Vischer, H.F., 2005. Fish FSH receptors bind LH: how to make the human FSH receptor to be more fishy? Gen. Comp Endocrinol. 142, 34-43.

Boime, I., Ben Menahem, D., 1999. Glycoprotein hormone structure-function and analog design. Recent Prog. Horm. Res. 54, 271-288.

Borg, B., 1994. Androgens in teleost fishes. Comp. Biochem. Physiol. C Comp. Pharmacol. Toxicol. 109, 219-245.

Bousfield, G. R., Perry, W. M., Ward, D. N., 1994. Gonadotropins. Chemistry and biosynthesis. In: Knobil, E., Neill, J. D. (Eds), The Physiology of Reproduction. Raven Press, New York, pp. 1749-1792.

Braun, T., Schofield, P.R., Sprengel, R., 1991. Amino-terminal leucine-rich repeats in gonadotropin receptors determine hormone selectivity. EMBO J. 10, 1885-1890.

Burzawa-Gerard, E., 1982. Chemical data on pituitary gonadotropins and their implication to evolution. Can. J. Fish Aquat. Sci. 39, 80-91.

Carrillo, M., Zanuy, S., Prat, F., Cerda, J., Ramos, H., Mañanós, E., Bromage, N., 1995. Sea bass. In: Bromage, N.R., Roberts, J. (Eds.), Broodstock Management and Egg and Larval Quality. Blackwell Science, London, pp. 138-168.

Copeland, P.A., Thomas, P., 1993. Isolation of gonadotropin subunits and evidence for two distinct gonadotropins in Atlantic croaker (Micropogonias undulatus). Gen. Comp. Endocrinol. 91, 115-125.

Cuisset, B., Pradelles, P., Kime, D.E., Kühn, E.R., Babin, P., Davail, S., Le Menn, F., 1994. Enzyme immunoassay for 11-ketotestosterone using acetylcholinesterase as label: application to the measurement of 11-ketotestosterone in plasma of Siberian sturgeon. Comp. Biochem. Physiol. C 108, 229-241.

Fiddes, J.C., Talmadge, K., 1984. Structure, expression, and evolution of the genes for the human glycoprotein hormones. Recent Prog. Horm. Res. 40, 43-78.

Fostier, A., Jalabert, B., Billard, R., Breton, B., Zohar, Y.,1983. The gonadal steroids. In: Donaldson, E. M. (ed.), Fish Physiology. Academic Press, New York, pp. 277-372.

García-Hernández, M.P., Koide, Y., Díaz, M.V., Kawauchi, H., 1997. Isolation and characterization of two distinct gonadotropins from the pituitary gland of Mediterranean yellowtail, Seriola dumerilii (Risso, 1810). Gen. Comp. Endocrinol. 106, 389-399.

Govoroun, M.S., Huet, J.C., Pernollet, J.C., Breton, B., 1997. Use of immobilized metal ion affinity chromatography and dye-ligand chromatography for the separation and purification of rainbow trout pituitary gonadotropins, GTH I and GTH II. J. Chromatogr. B Biomed. Sci. Appl. 698, 35-46.

Kagawa, H., Tanaka, H., Okuzawa, K., Kobayashi, M., 1998. GTH II but not GTH I induces final maturation and the development of maturational competence of oocytes of red seabream in vitro. Gen. Comp. Endocrinol. 112, 80-88.

Kamei, H., Kawazoe, I., Kaneko, T., Aida, K., 2005. Purification of follicle-stimulating hor- 
mone from immature Japanese eel, Anguilla japonica, and its biochemical properties and steroidogenic activities. Gen. Comp. Endocrinol. 143, 257-266.

Koide, Y., Itoh, H., Kawauchi, H., 1993. Isolation and characterization of two distinct gonadotropins, GTHI and GTHII, from bonito (Katsuwonus plelamis) pituitary glands. Int. J. Peptide Protein Res. 41, 52-65.

Laemmli, U.K., 1970. Cleavage of structural proteins during the assembly of the head of bacteriophage T4. Nature. 227, 680-685.

Li, M.D., Ford, J.J., 1998. A comprehensive evolutionary analysis based on nucleotide and amino acid sequences of the $\alpha$ - and $\beta$-subunits of glycoprotein hormone gene family. J. Endocrinol. 156, 529-542.

Mañanós, E.L., Swanson, P., Stubblefield, J., Zohar, Y., 1997. Purification of gonadotropin II from a teleost fish, the hybrid striped bass, and development of a specific enzyme-linked immunosorbent assay. Gen. Comp. Endocrinol. 108, 209-222.

Mateos, J., Mañanos, E., Martinez-Rodriguez, G., Carrillo, M., Querat, B., Zanuy, S., 2003. Molecular characterization of sea bass gonadotropin subunits ( $\alpha, \mathrm{FSH} \beta$, and LH $\beta$ ) and their expression during the reproductive cycle. Gen. Comp. Endocrinol. 133, 216-232.

Mateos , J., Mañanós, E., Swanson, P., Carrillo, M., Zanuy, S., 2006. Purification of luteinizing hormone $(\mathrm{LH})$ in the sea bass (Dicentrarchus labrax) and development of a specific immunoassay. Cienc. Mar. 32, 271-283.

Montserrat, N., González, A., Méndez, E., Piferrer, F., Planas, J.V., 2004. Effects of follicle stimulating hormone on estradiol-17 $\beta$ production and P-450 aromatase (CYP19) activity and mRNA expression in brown trout vitellogenic ovarian follicles in vitro. Gen. Comp. Endocrinol. 137, 123-131.

Moyle, W.R., Campbell, R.K., Myers, R.V., Bernard, M.P., Han, Y., Wang, X., 1994. Coevolution of ligand-receptor pairs. Nature. 368, 251-255.

Nagahama, Y., 1994. Endocrine regulation of gametogenesis in fish. Int. J. Dev. Biol. 38, 217-229.

Naito, N., Suzuki, K., Nozaki,M., Swanson, P., Kawauchi, H., Nakai, Y., 1993. Ultrastructural characteristics of two distinct gonadotropes (GTH I- and GTH II-cells) in the pituitary of rainbow trout Oncorhynchus mykiss. Fish Physiol. Biochem. 11, 241-246.

Nozaki, M., Naito, N., Swanson, P., Miyata, K., Nakai, Y., Oota, Y., Suzuki, K., Kawauchi, H., 1990. Salmonid pituitary gonadotrophs: I. Distinct cellular distributions of two gonadotropins GTH I and GTH II. Gen. Comp. Endocrinol. 77, 348- 357.

Ohta, T., Miyake, H., Miura, C., Kamei, H., Aida, K., Miura, T., 2007. Follicle-stimulating hormone induces spermatogenesis mediated by androgen production in Japanese eel, Anguilla japonica. Biol. Reprod. 77, 970-977.

Okada, T., Kawazoe, I., Kimura, S., Sasamoto, Y., Aida, K., Kawauchi, H., 1994. Purification and characterization of gonadotropin I and II from pituitary glands of tuna (Thunnus obesus). Int. J. Peptide Protein Res. 43, 69-80.

Pierce, J.G., Parsons, T.F., 1981. Glycoprotein hormones: structure and function. Annu. Rev. Biochem. 50, 465-495.

Planas, J.V., Swanson, P., Dickhoff, W.W., 1993. Regulation of testicular steroid production in vitro by gonadotropins (GTH I and GTH II) and cyclic AMP in coho salmon (Oncorhynchus kisutch). Gen. Comp. Endocrinol. 91, 8-24.

Planas, J.V., Swanson, P., 1995. Maturation-associated changes in the response of the salmon testis to the steroidogenic actions of gonadotropins (GTH I and GTH II) in vitro. 
Biol. Reprod. 52, 697-704.

Planas, J.V., Athos, J., Goetz, F.W., Swanson, P., 2000. Regulation of ovarian steroidogenesis in vitro by follicle-stimulating hormone and luteinizing hormone during sexual maturation in salmonid fish. Biol. Reprod. 62, 1262-1269.

Prat, F., Zanuy, S., Carrillo, M., de Mones, A., Fostier, A., 1990. Seasonal changes in plasma levels of gonadal steroids of sea bass, Dicentrarchus labrax L. Gen. Comp. Endocrinol. 78, 361-373.

Prat, F., Sumpter, J.P., Tyler, C.R., 1996. Validation of radioimmunoassays for two salmon gonadotropins (GTH I and GTH II) and their plasma concentrations throughout the reproductive cycle in male and female rainbow trout (Oncorhynchus mykiss). Biol. Reprod. 54, 1375-1382.

Querat, B., Sellouk, A., Salmon, C., 2000. Phylogenetic analysis of the vertebrate glycoprotein hormone family including new sequences of sturgeon (Acipenser baeri) $\beta$ subunits of the two gonadotropins and the thyroid-stimulating hormone. Biol. Reprod. 63, 222228.

Rocha, A., Gomez, A., Zanuy, S., Cerda-Reverter, J.M., Carrillo, M., 2007. Molecular characterization of two sea bass gonadotropin receptors: cDNA cloning, expression analysis, and functional activity. Mol. Cell. Endocrinol. 272, 63-76.

Rodríguez, L., Begtashi, I., Zanuy, S., Carrillo, M., 2000. Development and validation of an enzyme immunoassay for testosterone: Effects of photoperiod on plasma testosterone levels and gonadal development in male sea bass (Dicentrarchus labrax, L.) at puberty. Fish Physiol. Biochem. 23, 141-150.

Rodríguez, L., Carrillo, M., Sorbera, L.A., Zohar, Y., Zanuy, S., 2004. Effects of photoperiod on pituitary levels of three forms of GnRH and reproductive hormones in the male European sea bass (Dicentrarchus labrax, L.) during testicular differentiation and first testicular recrudescence. Gen. Comp. Endocrinol. 136, 37-48.

Rodríguez, L., Begtashi, I., Zanuy, S., Carrillo, M., 2005. Long-term exposure to continuous light inhibits precocity in European male sea bass (Dicentrarchus labrax, L.): hormonal aspects. Gen. Comp. Endocrinol. 140, 116-125.

Santos, E.M., Rand-Weaver, M., Tyler, C.R., 2001. Follicle-stimulating hormone and its $\alpha$ and $\beta$ subunits in rainbow trout (Oncorhynchus mykiss): purification, characterization, development of specific radioimmunoassays, and their seasonal plasma and pituitary concentrations in females. Biol. Reprod. 65, 288-294.

Shimizu, A., Yamashita, M., 2002. Purification of mummichog (Fundulus heteroclitus) gonadotropins and their subunits, using an immunochemical assay with antisera raised against synthetic peptides. Gen. Comp. Endocrinol. 125, 79-91.

Schulz, R.W., Miura, T., 2002. Spermatogenesis and its endocrine regulation. Fish Physiol. Biochem. 26, 43-56.

Sorbera, L.A., Asturiano, J.F., Carrilo, M., Cerdà, J., Kime, D.E., Zanuy, S., 1999. In vitro oocyte maturation in the sea bass: effects of hCG, pituitary extract and steroids. J. Fish Biol. 55, 9-25.

Suzuki, K., Kawauchi, H., Nagahama, Y., 1988a. Isolation and characterization of two distinct gonadotropins from chum salmon pituitary glands. Gen. Comp. Endocrinol. 71, 292-301.

Suzuki, K., Kawauchi, H., Nagahama, Y., 1988b. Isolation and characterization of subunits from two distinct salmon gonadotropins. Gen. Comp. Endocrinol. 71, 302-306. 
Suzuki, K., Nagahama, Y., Kawauchi, H., 1988c. Steroidogenic activities of two distinct salmon gonadotropins. Gen. Comp. Endocrinol. 71, 452-458.

Suzuki, K., Kanamori, A., Nagahama, Y., Kawauchi, H., 1988d. Development of salmon GTH I and GTH II radioimmunoassays. Gen. Comp. Endocrinol. 71, 459-467.

Swanson, P., Suzuki, K., Kawauchi, H., Dickhoff, W.W., 1991. Isolation and characterization of two coho salmon gonadotropins, GTH I and GTH II. Biol. Reprod. 44, 29-38.

Swanson, P., Dickey, J.T., Campbell, B., 2003. Biochemistry and physiology of fish gonadotropins. Fish Physiol. Biochem. 28, 53-59.

Tanaka, H., Kagawa, H., Okuzawa, K., Hirose, K., 1993. Purification of gonadotropins (Pm GTH I and II) from red seabream (Pagrus major) and development of a homologous radioimmunoassay for PmGTH II. Fish Physiol. Biochem. 10 (5), 409-418.

Van der, K.G., Suzuki, K., Peter, R.E., Itoh, H., Kawauchi, H., 1992. Properties of common carp gonadotropin I and gonadotropin II. Gen. Comp. Endocrinol. 85, 217-229.

Weltzien, F.A., Norberg, B., Swanson, P., 2003. Isolation and characterization of FSH and LH from pituitary glands of Atlantic halibut (Hippoglossus hippoglossus L.). Gen. Comp. Endocrinol. 131, 97-105.

Yaron, Z., Gur, G., Melamed, P., Rosenfeld, H., Elizur, A., Levavi-Sivan, B., 2003. Regulation of fish gonadotropins. Int. Rev. Cytol. 225, 131-185.

Yaron, Z., Sivan, B., 2006. Reproduction. In: Evans, D.H. \& Claibourne, J.B. (Eds.), The Physiology of Fishes. CRC Press, Boca Raton, pp. 343-386. 




\section{Capítulo 5:}

Receptor Specificity and Functional Comparison of Recombinant Sea Bass (Dicentrarchus labrax) Gonadotropins (Fsh and Lh) Produced in Different Host Systems

Gregorio Molés, Silvia Zanuy, Iciar Muñoz, Berta Crespo, Iago Martínez, Evaristo Mañanós, Ana Gómez Biology of Reproduction 84, 1171-1181 (2011) 



\begin{abstract}
Different yields, biopotency, and in vivo pharmacokinetics are obtained for recombinant sea bass gonadoltropins depending on the production system and DNA construct, but they show specific activation of their corresponding receptors. Gonadotropins (GTHs) are glycoprotein hormones that play a major role in the regulation of gonadal functions. Recently, we succeeded in isolating the native sea bass Fsh from sea bass pituitaries, but to ensure the availability of bioactive GTHs and no cross-contamination with other related glycoproteins, recombinant sea bass GTHs were produced using two expression systems-insect and mammalian cells-and different constructs that yielded tethered or noncovalently bound dimers. Their production levels, binding specificity to their homologous cognate receptors, and bioactivity were investigated and compared. Both expression systems were successful in the generation of bioactive recombinant GTHs, but insect Sf9 cells yielded higher amounts of recombinant proteins than mammalian Chinese Hamster Ovary (CHO) stable clones. All recombinant GTHs activated their cognate receptors without cross-ligand binding and were able to stimulate sea bass gonadal steroidogenesis in vitro, although with different biopotencies. To assess their use for in vivo applications, their half-life in sea bass plasma was evaluated. Sf9-GTHs had a lower in vivo stability compared with $\mathrm{CHO}-\mathrm{GTH}$ due to their rapid clearance from the blood circulation. Cell-dependent glycosylation could be contributing to the final in vivo stability and biopotency of these recombinant glycoproteins. In conclusion, both insect and mammalian expression systems produced bioactive sea bass recombinant gonadotropins, although with particular features useful for different proposes (e.g., antibody production or in vivo studies, respectively).
\end{abstract}

Keywords: fish, follicle-stimulating hormone, FSH/FSH receptor, gametogenesis, in vivo half-life, LH/LH receptor, luteinizing hormone, perciform, protein expression, single-chain GTHs, steroidogenesis 


\section{Introduction}

The gonadotropins (GTHs)-follicle-stimulating hormone (FSH) and luteinizing hormone ( $\mathrm{LH}$ - - produced in the pituitary gland are essential in the endocrine control of vertebrate reproduction. Together with the pituitary-derived thyroid-stimulating hormone (TSH) and the placental chorionic gonadotropin (CG), which is present only in primate and equine species, they constitute an evolutionarily conserved family of glycoprotein hormones. They are glycosylated heterodimers formed by the noncovalent association of an $\alpha$ subunit (Cga), which is common to all members of the family within a species, with distinct $\beta$ subunits (Fshb and Lhb) that confer hormone specificity $[1,2]$. Each subunit is encoded by a single, separate gene [3]. The dimerization and glycosylation are prerequisites for GTHs to achieve full biological activity.

Since late 1980s, GTHs have been isolated and characterized in several fish species [4]. As in higher vertebrates, GTHs regulate gametogenesis and steroidogenesis. Nevertheless, the functional duality between Fsh and Lh has not yet been well clarified in perciform fish, mainly because of the lack of appropriate tools for their study. In salmonids, from which most of the information regarding GTHs comes, Fsh is considered to regulate early phases of gametogenesis, such as vitellogenesis and spermatogenesis, whereas Lh is considered to be responsible for the final maturation processes, such as oocyte maturation, ovulation, and spermiation $[5,6]$.

Access to bioactive and pure fractions of homologous GTHs is essential for studies aiming to reveal their differential functions in each fish species. Traditionally, pure, intact fish GTHs have been obtained by purification of the native hormones from pituitary glands. This is a highly demanding process with regard to time, cost, and the substantial amount of pituitary glands required; in addition, it has not always been successful [7, 8]. The availability of recombinant GTHs is an attractive alternative to native hormones that can facilitate physiological studies and be used in the development of biotechnological applications. They can be continually produced, assuring their availability and no cross-contamination with other related glycoproteins. The isolation and characterization of cDNAs encoding GTH subunits in a wide range of fish species provide the possibility to produce speciesspecific recombinant GTHs, although this has only been accomplished in 
a handful of fish species in the last decade. Fish recombinant GTHs have been produced by means of various expression platforms, mainly eukaryotic systems that permit appropriate posttranslational modifications, such as glycosylation [7-13]. Production was accomplished by coexpression of both subunit genes (cga and $f$ shb/lhb) or by fusion of their cDNAs, giving rise to a single protein known as single-chain GTH. All different approaches have generated bioactive recombinant GTHs, but they show different strengths and weaknesses, mainly concerning high-yield production and stability.

As a second step toward elucidating the gonadotropic regulation of gametogenesis in fish, full-length cDNAs encoding the receptors for Fsh (Fshr) and Lh (Lhr) were isolated from the gonads of several fish species [14]. As in other vertebrates, they are $\mathrm{G}$ protein-coupled receptors. Ligand binding activates the Gs/adenylate cyclase pathway, and the increased cAMP levels initiate a signaling cascade that leads to steroid synthesis $[15,16]$. Despite their overall structural conservation, in vitro binding and functional studies revealed promiscuous ligand recognition of fish GTH receptors, in contrast to the strict ligand selectivity described in mammals. Depending on the species and origin of the GTHs (homologous/heterologous), a promiscuous activation of the Fshr or the Lhr was reported in studies using mammalian cell lines expressing recombinant fish GTH receptors [8, 10, 17-22]. These observations may complicate the interpretation of their specific roles.

The European sea bass is a perciform fish whose reproduction period is once a year during the winter season. Females present a group-synchronous type of ovarian development, producing three to four consecutive spawns during the 1- to 2-mo spawning period [23-25]. In this fish, the roles of Fsh in the reproductive processes are not clarified. Recently, the purification of sea bass Fsh from pituitary glands [26] has allowed the study of some aspects of steroidogenesis in this species. However, the limited quantities of hormone obtained, together with the unavailability of native Lh dimer for functional comparative studies motivated the development of recombinant GTHs.

In the available reports on production of recombinant fish GTHs, a specific expression system and DNA construct have been chosen in each case. In the present study, we intended to produce and characterize recombinant Fsh and Lh for sea bass, but also to compare expression systems and expression constructs. We chose two expression systems representing distant eukaryotes: insect (invertebrate) and mammalian cells, and DNA constructs 
leading to the production of both separate and tethered subunits. Finally, we assessed and compared their function regarding receptor activation specificity and biopotency, gonadal steroidogenic ability, and in vivo stability, using homologous targets and receptors. This functional characterization provides new data on sea bass GTH action in GTH-receptor interactions, and sets a fundamental basis for the use of recombinant GTHs for future applications.

\section{Materials and methods}

\subsection{Production of recombinant Fsh and Lh in insect cells (Sf9)}

\section{Construction of cga, fshb and lhb subunit transfer vectors}

Complementary DNA fragments containing the entire open reading frames (ORFs) of sea bass cga (416 bp), fshb (480 bp), and lhb (487 bp; GenBank accession numbers: AF269157, AF543314, and AF543315) were obtained by PCR using specific primers (Supplemental Table S1, Nos. 1 to 6; available online at www. biolreprod.org) and the proofreading PfuTurbo

Table S1. PCR primers used in this study.

\begin{tabular}{|c|c|c|c|c|}
\hline Gene & $N^{o}$ & Direction $^{a}$ & Primer sequence $e^{b, c, d}$ & Restriction sites \\
\hline \multirow[t]{2}{*}{$\operatorname{cg} a$} & 1 & F: & 5' -GGGGATCCCTTTCTCTCAACATGGTAAC-3' & Bam HI \\
\hline & 2 & $\mathrm{R}:$ & 5' -GGAAGCTTGAATGGTCTCCAGTTCCCAT-3' & Hind III \\
\hline \multirow[t]{2}{*}{$f_{s h b}$} & 3 & F: & $5^{\prime}$-GGGAATTCGTTTAGAGATTGACAGAAGAAGC-3' & Eco RI \\
\hline & 4 & R: & $\begin{array}{l}5^{\prime} \text { - ATGCGGCCGCTTAATGATGATGATGATGATGAA } \\
\text { AGGACAGACAGCTGGGTAT-3' }\end{array}$ & Not $\mathrm{I}$ \\
\hline \multirow[t]{2}{*}{$l h b$} & 5 & F: & $5^{\prime}$-GGGGATCCCCAGAGAGGATGATGGCTGT-3' & Bam HI \\
\hline & 6 & $\mathrm{R}:$ & 5' -GGAAGCTTATGTGCTTCATGCTGCTATT-3' & Hind III \\
\hline \multirow[t]{3}{*}{$f s h b-\mathrm{CTP}$} & 7 (B1) & $\mathrm{F}$ & 5' -CCGGGATCCGTTTAGAGATTGACAGAAGAA-3' & Bam HI \\
\hline & $8(\mathrm{~B} 2)$ & $\mathrm{R}$ & $5^{\prime}-$ TGAGGAAGAGGAAAAGGACAGACAGCTGGG-3' & \\
\hline & 9 (B3) & $\mathrm{F}$ & 5'-TGTCTGTCCTTT TCCTCTTCCTCAAAGGCC-3' & \\
\hline \multirow[t]{3}{*}{$l h b-\mathrm{CTP}$} & $10(\mathrm{~B} 1)$ & $\mathrm{F}$ & 5 ' -CCGGGGATCCCCAGAGAGGATGATGGCTGTG-3' & Bam HI \\
\hline & $11(\mathrm{~B} 2)$ & $\mathrm{R}$ & 5 ' - TGAGGAAGAGGAGTAGTAGAAAGGTATGTC-3' & \\
\hline & $12(\mathrm{~B} 3)$ & $\mathrm{F}$ & 5 ' -ССТTTCTACTAC TCСTCTTCCTCAAAGGCC-3 ' & \\
\hline \multirow[t]{3}{*}{ cga-CTP } & 13 (A1) & $\mathrm{R}$ & 5' -CATGCTGGGGTATTGTGGGAGGATCGG-3' & \\
\hline & $14(\mathrm{~A} 2)$ & $\mathrm{F}$ & $5^{\prime}$ - АTCCTCCCACAATACCCCAGCATGGACTTA-3' & \\
\hline & 15 (A3) & $\mathrm{R}$ & 5 '-CGGAATTCCATGAAAGTGCAACATCTG-3' & Eco RI \\
\hline
\end{tabular}

${ }^{\mathrm{a}}$ F: Forward, R: Reverse; ${ }^{\mathrm{b}}$ Bold: Restriction enzyme recognition sites; ${ }^{\mathrm{c}}$ Underline: sequence for six histidine residues; ${ }^{\mathrm{d}}$ Italics: CTP. 
DNA polymerase (Stratagene). Restriction sites were added at the 5' end of the forward and reverse primers. These fragments were directionally cloned into the donor plasmid pFastBac1 between BamHI/HindIII (pFastBac1-Cga and pFastBac1-Lhb) or EcoRI/NotI (pFastBac1-Fshb) restriction sites. All of the constructs were sequenced to confirm their identity.

\section{Generation of recombinant baculovirus}

Recombinant baculovirusexpressing sea bass $c g a, f s h$, and $l h b$ were generated independently using the Bac-to-Bac Baculovirus Expression System (Invitrogen). Briefly, competent Escherichia coli DH10Bac was transformed with the recombinant donor plasmids pFastBac1-Cga, pFastBac1-Fshb, or pFastBac1-Lhb for transposition into the bacmid. Recombinant bacmids were then used to transfect insect cells, Spodoptera frugiperda (Sf9), with Cellfectin Reagent (Invitrogen) according to the manufacturer's protocol. Sf9 cells were grown in monolayer at $28^{\circ} \mathrm{C}$ in Sf-900 II SFM medium (Invitrogen) containing $100 \mathrm{U} / \mathrm{ml}$ penicillin and $100 \mu \mathrm{g} / \mathrm{ml}$ streptomycin (Invitrogen). After $72 \mathrm{~h}$, recombinant baculovirus was harvested from the medium. Viral stocks were amplified by infection of Sf9 cells at a multiplicity of infection (MOI) of 0.1 for $48 \mathrm{~h}$ at $28^{\circ} \mathrm{C}$ to achieve final viral titers of $2 \times 10^{7}$ to $5 \times 10^{7}$ plaque-forming units ( $\mathrm{pfu}$ ) per milliliter as assessed by viral plaque assay.

\section{Production of recombinant Fsh and Lh in Sf9 cells}

Monolayer cultures of Sf9 cells were grown in $75-\mathrm{cm}^{2}$ flasks to $80 \%-85 \%$ confluence (approximately $12 \times 10^{6}$ cells). Optimal results for the expression of GTH subunits were obtained when Sf9 cells were infected at an MOI of 3 $\mathrm{pfu} / \mathrm{ml}$ during 4-5 days. Cells and medium were then harvested by centrifugation $(110 \times \mathrm{g}, 10 \mathrm{~min})$ and stored at $-80^{\circ} \mathrm{C}$ until used. The infected cells were resuspended in lysis buffer $(50 \mathrm{mM}$ Tris- $\mathrm{HCl}, \mathrm{pH} 8.0 ; 100 \mathrm{mM} \mathrm{KCl} ; 1 \%$ Nonidet P-40; $1 \mathrm{mM}$ PMSF; and $1 \mu \mathrm{g} / \mathrm{ml}$ aprotinin) and their cell membrane disrupted by brief periods of sonication on ice using a cell disrupter (Vibracell; Sonics \& Materials, Inc.). Supernatants containing soluble proteins were recovered after removal of cell debris by centrifugation at $35000 \times \mathrm{g}$ for $30 \mathrm{~min}$ at $4^{\circ} \mathrm{C}$.

For production of sea bass Fsh and Lh dimers, Sf9 cells were coinfected with a 1:1 ratio of baculovirus Cga: $\beta$ subunit (Fshb or Lhb, respectively) at an MOI of $3 \mathrm{pfu} / \mathrm{ml}$. Twenty-four hours after infection, fresh culture medium was added, and cells were incubated at $28^{\circ} \mathrm{C}$ for 4 days. Finally, the medium 
was harvested and the presence of recombinant dimeric GTHs assessed.

\subsection{Production of recombinant Fsh and Lh in Chinese Hamster Ovary cells}

\section{Construction of expression plasmids}

A cDNA fragment containing the entire ORF of sea bass $f s h b$ and a Cterminal 6xHis tag was obtained by PCR using the specific primers 3 and 4 (Supplemental Table S1) and directionally subcloned into the EcoRI/No$t \mathrm{I}$-digested pcDNA3 plasmid (Invitrogen) to generate pcDNA3-Fshb. The pCMVtk-Cga plasmid contains the full-length cga cDNA under the control of the CMVtk promoter, followed by an SV40 polyadenylation signal. All of the constructs were sequenced to confirm sequence identity.

Single-chain Fsh (scFsh) and Lh (scLh) were constructed by in-frame fusion of the sea bass cga and $\beta$ subunit cDNAs of each hormone using the carboxy-terminal peptide (CTP; 28 amino acids) from the human chorionic gonadotropin (hCG) $\beta$ subunit as a linker. Sequential overlapping PCR [27, 28] reactions were performed using primers 7 to 15 (Supplemental Table S1; see Fig. 1 for a diagram) and the high-fidelity PfuTurbo DNA polymerase

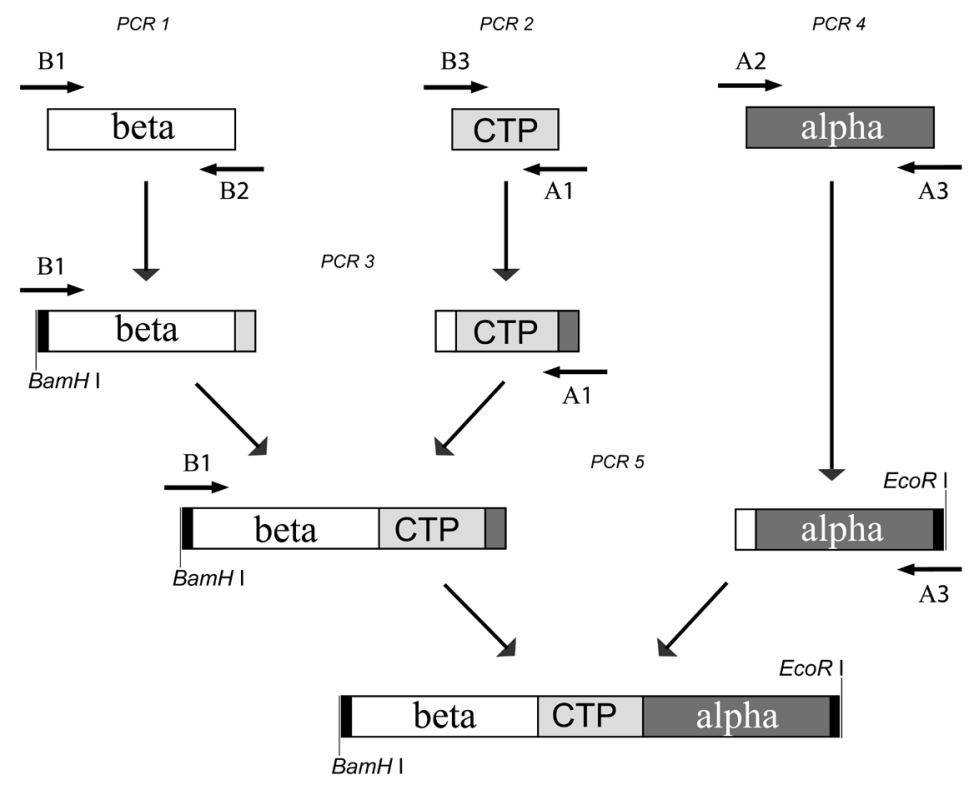

Figure 1. Diagram of construction of single-chain GTHs using overlapping PCR. 
(Stratagene). Expression plasmids containing the $h C G B$ (kindly provided by Dr. Irving Boime, Washington University), and the cDNAs for sea bass $f s h b$, $l h b$, and $c g a$ were used as templates. In the instance of $c g a$, the sequence coding for the signal peptide was removed. The PCR-generated fusion fragments for Fsh and Lh were completely sequenced to ensure sequence identity. Each of these tethered cDNAs (scfsh and sclh) was inserted into the expression vector pcDNA3 (Invitrogen) as BamHI/EcoRI fragments, and the resulting expression plasmids were named pCMV-scFsh and pCMV-scLh, respectively.

Generation of Chinese Hamster Ovary stable clones and production of recombinant GTHs

Chinese Hamster Ovary $(\mathrm{CHO})$ cells were cultured in Dulbecco modified Eagle medium (DMEM; Invitrogen) supplemented with $100 \mathrm{U} / \mathrm{ml}$ penicillin, $100 \mu \mathrm{g} / \mathrm{ml}$ streptomycin, and $5 \%$ fetal bovine serum (FBS), at $37^{\circ} \mathrm{C}$ with $5 \%$ $\mathrm{CO}_{2}$. Cells were transfected in 24-well plates using Lipofectamine Reagent (Invitrogen) according to the manufacturer's protocol. Equal amounts of $\mathrm{pC}$ MVtk-Cga and pcDNA3-Fshb were cotransfected to express the Fsh dimer, and pCMV-scFsh or pCMV-scLh was transfected to express single-chain Fsh or Lh, respectively. To obtain the stable clones, $48 \mathrm{~h}$ after transfection cells were replated in 96-well plates and selected in medium containing 500 $\mu \mathrm{g} / \mathrm{ml}$ G418 (Geneticin; Invitrogen). The isolated stable clones (CHO-Fsh, $\mathrm{CHO}$-scFsh, and CHO-scLh) were expanded, and the cells and conditioned medium were screened for the presence of Fsh and Lh by Northern blotting, Western blotting, and receptor activation.

For each construct, one selected clone expressing the hormone was grown according to the protocol described by Schatz et al. [29] in $75-\mathrm{cm}^{2}$ cell culture flasks until $80 \%-90 \%$ confluence in selective medium. The FBS-containing medium was then replaced by Advanced DMEM (Invitrogen) serum-free medium supplemented with $100 \mathrm{U} / \mathrm{ml}$ penicillin, $100 \mu \mathrm{g} / \mathrm{ml}$ streptomycin, and $1 \%$ glutamine. The cells were further incubated for 9 days at $25^{\circ} \mathrm{C}$. Then, the culture supernatants were harvested and stored at $-80^{\circ} \mathrm{C}$.

\subsection{Recombinant hormone concentration}

The harvested media (Sf9-Fsh, Sf9-Lh, Sf9-Fshb, Sf9-Lhb, CHO-Fsh, $\mathrm{CHO}$-scFsh, $\mathrm{CHO}-\mathrm{scLh}$, and $\mathrm{CHO}$ control) were concentrated by ultrafil- 
tration using Centricon Plus-20 Biomax 5 (subunits and dimers) and Ultracel PL 30 (single chains) centrifugal filter devices (Amicon; Millipore Corp.). In the different experiments, the concentration of recombinant GTHs used is expressed as a dilution factor of the culture medium (Table 1).

\subsection{SDS-PAGE and Western blot analysis}

Recombinant proteins were electrophoresed through 15\% SDS-PAGE gels under reducing conditions (5\% 2-mercaptoethanol [2-ME]). The separated proteins were transferred to PVDF membranes (Immobilon P; Millipore Corp.), blocked overnight with $5 \%$ skimmed milk at $48 \mathrm{C}$, incubated with the specific antisera (dilutions 1:2000 and 1:3500) for $90 \mathrm{~min}$ at room temperature, washed, and further incubated with 1:2000 goat anti-rabbit immunoglobulin G (IgG) horseradish peroxidase conjugate (GAR-HRP; BioRad Laboratories) for $60 \mathrm{~min}$ at room temperature. The immunodetection was performed by chemiluminescence (Western Blotting Luminol Reagent; Santa Cruz Biotechnology Inc.). Antibodies against sea bass (sbs) Cga and Lhb subunits (1:2000) [30], and a mummichog (Fundulus heteroclitus) Fshb (mFshb) antibody (1:3500) [31] already tested for sea bass [26] were used as antisera. In all cases, the molecular weights were estimated by SDS-PAGE.

\subsection{Glycosidase treatments}

Concentrated media $(3-10 \mu \mathrm{l})$ containing sea bass GTH dimers were denatured at $94^{\circ} \mathrm{C}$ for $5 \mathrm{~min}$ in $0.1 \%$ SDS and $50 \mathrm{mM}$ 2-ME. Then, media were incubated with 2.5 units of peptide- $N$-glycosidase F (PNGase F; Roche Di-

Table 1. Amount of recombinant sea bass gonadotropins after concentration by ultrafiltration.

\begin{tabular}{llll} 
Hormone & Fold concentration $^{\text {a }}$ & Concentration (1x) & Quantification method \\
\hline Sf9-Fsh & $40 \mathrm{x}$ & $24.8-4.12 \mu \mathrm{g} / \mathrm{ml}$ & I. dot-blot / Bioassay FSH-R \\
Sf9-Lh & $50 \mathrm{x}$ & $2.8 \mu \mathrm{g} / \mathrm{ml}$ & ELISA LH \\
Sf9-Lhb & $25 \mathrm{x}$ & $2.2 \mu \mathrm{g} / \mathrm{ml}$ & ELISA LH \\
CHO-Fsh & $294 \mathrm{x}$ & $0.650-0.011 \mu \mathrm{g} / \mathrm{ml}$ & I. dot-blot / Bioassay FSH-R \\
CHO-scFsh & $160 \mathrm{x}$ & $0.405-0.1 \mu \mathrm{g} / \mathrm{ml}$ & I. dot-blot / Bioassay FSH-R \\
CHO-scLh & $195 \mathrm{x}$ & $0.03 \mu \mathrm{g} / \mathrm{ml}$ & ELISA LH
\end{tabular}

${ }^{\mathrm{a}}$ Number of folds that the culture medium was concentrated. 
agnostics) at $37^{\circ} \mathrm{C}$ for $16 \mathrm{~h}$ in $20 \mathrm{mM}$ sodium phosphate with $0.5 \%$ Nonidet P-40, pH 7.5. Deglycosylated proteins were subjected to SDS-PAGE followed by Western blot analysis.

\subsection{Activation of sea bass Fsh and Lh receptors}

The biological activity of the recombinant hormones were analyzed using Human Embryonic Kidney (HEK) 293 cell lines stably expressing the sea bass Fsh or Lh receptor (sbsFshr and sbsLhr) and the firefly luciferase gene under the control of a promoter with cAMP responsive element (CRE)binding sites (pCRE-LUC) [20]. Receptor activation by recombinant Fsh or Lh was indirectly measured by recording changes in luciferase activity, promoted by a rise of cAMP. Cells from the HEK 293 clones were seeded in 48-well plates and incubated with serial dilutions of recombinant sea bass Fsh or Lh preparations in Advanced DMEM media (Invitrogen). After $5 \mathrm{~h}$ of incubation, cells were lysed in Reporter Lysis Buffer (Promega Corp.) as indicated by the manufacturer. Cell debris was separated by centrifugation for $30 \mathrm{sec}$ at $15000 \mathrm{x}$, and $20 \mu \mathrm{l}$ of the supernatant was mixed with $100 \mu \mathrm{l}$ of luciferin reagent (20 mM Tricine $\mathrm{KOH}, \mathrm{pH}$ 7.8; $0.1 \mathrm{mM}$ ethylenediaminetetraacetic acid; $8 \mathrm{mM} \mathrm{MgCl}_{2} ; 33.3 \mathrm{mM}$ dithiothreitol; $270 \mu \mathrm{M}$ coenzyme A; $530 \mu \mathrm{M}$ ATP; and $400 \mu \mathrm{M}$ luciferin). Light emission was measured in a luminometer (Junior; EG\&G Berthold) and expressed as relative light units.

HEK 293 cells expressing the sbsFshr were also used to calculate the effective ligand concentrations (native and recombinant Fsh) inducing a halfmaximal stimulation $\left(\mathrm{EC}_{50}\right)$.

Recombinant human FSH (rhFSH; AFP8468A; biopotency 8000 IU/mg) was obtained from the National Hormone \& Peptide Program, HarborUCLA Medical Center. Lyophilized hCG from urine of pregnant women was purchased at a local pharmacy (hCG-lepori 2500 IU; Farma-Lepori).

\subsection{In vitro sex steroid production and follicle maturation}

In vitro tissue culture of sea bass gonads was performed following the protocol described by Molés et al. [26]. Briefly, ovaries (in early to mid vitellogenesis) and testis (in late spermatogenesis) of adult sea bass killed between October and November were thoroughly chopped on ice with a razor blade until forming a paste. The tissue preparation was washed three times 
with $10 \mathrm{vol} / \mathrm{wt}$ of ice-cold Sea Bass Ringer (SBR; according to Sorbera et al. [32]) containing 0.5\% bovine serum albumin (Fraction V; Sigma-Aldrich Inc.) and $100 \mathrm{U} / \mathrm{ml}$ penicillin/ streptomycin (Invitrogen Corp.). After each wash, the tissue was centrifuged at $60 \times \mathrm{g}$ for $10 \mathrm{~min}$ at $4^{\circ} \mathrm{C}$, and the supernatant was discarded. In the last wash, the preparation was filtered through a $750-\mu \mathrm{m}$ (for testis) or $150-\mu \mathrm{m}$ (for ovary) nylon mesh. Pieces of the gonadal preparation were transferred to 24 -well plates $(40 \mathrm{mg}$ per well) and preincubated shaking $(100 \mathrm{rpm})$ in SBR $\left(0.5 \mathrm{ml}\right.$ per well) for $30 \mathrm{~min}$ at $18^{\circ} \mathrm{C}$. Then, the medium was replaced with fresh SBR $(0.5 \mathrm{ml}$ per well) containing different dilutions of recombinant sea bass Fsh or Lh. Tissues were further incubated for $20 \mathrm{~h}$ at $18^{\circ} \mathrm{C}$ and $100 \mathrm{rpm}$. Finally, the medium was collected, centrifuged at $500 \mathrm{xg}$ for $15 \mathrm{~min}$ at $4^{\circ} \mathrm{C}$, and the supernatant stored at $-20^{\circ} \mathrm{C}$ until steroid analysis. Each treatment was repeated four times, and the experiments were performed in triplicate.

Follicles from adult sea bass killed in January were cultured according to Sorbera et al. [32]. Only vitellogenic and postvitellogenic intact follicles with opaque cytoplasm and no indication of yolk clarification or lipid droplet coalescence were chosen for incubation. Oocytes were manually isolated from the ovarian tissue on ice, placed in SBR, and allowed to stabilize at $18^{\circ} \mathrm{C}$ for $30 \mathrm{~min}$ prior to treatments. For scFsh stimulation, follicles were placed in 48-well plates (45-70 follicles per well) containing different doses of scFsh in $250 \mu \mathrm{l}$ of SBR. After $48 \mathrm{~h}$ of incubation at $18^{\circ} \mathrm{C}$, the medium was collected and stored at $-20^{\circ} \mathrm{C}$ until estradiol (E2) analysis. Each dose was tested in triplicate, and the experiment was repeated three times. For scLh treatment, 30 postvitellogenic follicles per dose were individually incubated in 96-well plates in $100 \mu \mathrm{l}$ of SBR for $48 \mathrm{~h}$. The experiment was repeated twice. Maturation, which included both mature/preovulatory and ovulated oocytes, was confirmed by visual assessment of volume increase, lipid droplet coalescence, yolk clarification, and germinal vesicle migration and breakdown [32].

\subsection{Hormone analysis}

Estradiol was measured by a conventional enzyme immunoassay (EIA), which was validated for sea bass in our laboratory. The protocol was similar to that previously developed for testosterone determination [33]. Briefly, culture medium was extracted with methanol, which was further evapo- 
rated. The dry extract was reconstituted in assay buffer (EIA buffer; Cayman Chemical). Each component, E2-acetylcholinesterase tracer, anti-E2 rabbit antiserum, and E2 standards (Sigma-Aldrich Inc.), or samples were added to 96 -well microtiter plates coated with mouse anti-rabbit IgG monoclonal antibodies (Clone RG-16; Sigma-Aldrich Inc.) and incubated overnight at $37^{\circ} \mathrm{C}$. Then, plates were rinsed, and color development was performed by addition of Ellman reagent and incubation for $2 \mathrm{~h}$ at $20^{\circ} \mathrm{C}$ in the dark. Optical density was read at $405 \mathrm{~nm}$ using a microplate reader (Bio-Rad microplate reader model 3550). The sensitivity of the assay was $0.156 \mathrm{ng} / \mathrm{ml}(\mathrm{Bi} / \mathrm{B} 0=$ $90 \%)$ with a slope of 0.956 . The interassay coefficient of variation $(n=12)$ was $9.38 \%$.

11-Ketotestosterone (11-KT) was determined by an EIA developed for the Siberian sturgeon [34] and modified for use in sea bass [35]. The assay sensitivity was $0.0012 \mathrm{ng} / \mathrm{ml}(\mathrm{Bi} / \mathrm{B} 0=90 \%)$.

Levels of recombinant sea bass Lh in culture medium or plasma samples were measured by a homologous competitive ELISA according to Mateos et al. [30]. The sensitivity of the assay was $0.65 \mathrm{ng} / \mathrm{ml}(\mathrm{Bi} / \mathrm{B0}=80 \%)$.

The amount of recombinant sea bass Fsh produced by $\mathrm{Sf} 9$ and $\mathrm{CHO}$ cells was determined by an immunodot blot assay with the $\mathrm{mFshb}$ antisera already described. Briefly, the proteins present in the culture media were denatured (5\% 2-ME, $4 \mathrm{~min}$ at $\left.95^{\circ} \mathrm{C}\right)$ and immobilized in a PVDF membrane using a Bio-Dot microfiltration apparatus (Bio-Rad Laboratories). The membrane was processed as in the Western blot assay (anti-mFshb, 1:3500; GARHRP, 1:2000). The immunodetection was performed by chemiluminescence (Luminol Reagent) using the image system Versadoc (Bio-Rad Laboratories). The intensity of the dots was quantified with the image analysis software Quantity One v 4.4 (Bio-Rad Laboratories). Known quantities of purified native sea bass Fsh [26] were used as standard curve.

Levels of bioactive sea bass Fsh in plasma samples were estimated by receptor activation as described above using the sbsFshr/pCRE-LUC HEK 293 stable clone [26] and 96-well plates. Plasma samples were diluted 1:25 and measured in triplicate. After $6 \mathrm{~h}$ of incubation, luciferase activity was quantified directly on the plates using the Steady-Glo Luciferase Assay System (Promega Corp.) and the ULTRA Evolution (Tecan) detection platform. Intraassay and interassay coefficients of variation were $6.9 \%$ and $9.5 \%$, respectively. The sensitivity of the bioassay was $0.104 \mathrm{ng} / \mathrm{ml}$.

By using both determination methods, the in vitro biological:immuno- 
logical ratio (B:I) could be calculated (i.e., Fsh concentration from the in vitro bioassay relative to that yielded by the immunodot blot).

\subsection{In vivo half-life evaluation}

Juvenile sea bass (51-94 g body mass) were used for pharmacokinetic analysis of recombinant sea bass GTHs (7-10 fish per group). A single dose of Sf9-Fsh (200 ng per fish), Sf9-Lh (500 ng per fish), scLh (52 ng per fish), or scFsh (200 ng per fish) diluted in PBS was administered by intramuscular injection. Noninjected animals or animals injected with Sf9-Fshb, Sf9-Lhb, or wild-type $\mathrm{CHO}$ conditioned concentrated medium served as controls. Blood samples $(0.2 \mathrm{ml})$ were collected at different times $(0,0.5,1,3,6,12,24$, 48 , and $72 \mathrm{~h}$ ) after injection. Plasma was obtained by centrifugation (3000 $\mathrm{x} g$ for $30 \mathrm{~min}$ at $4^{\circ} \mathrm{C}$ ) and stored at $-20^{\circ} \mathrm{C}$ until hormone measurements. Clearance rate was calculated as the relationship clearance rate $=$ dose/area under the concentration-time curve. The area under the concentration-time curve was calculated using NCSS software.

Animals used for in vivo studies or as a source of gonadal tissue were treated in accordance with the Spanish legislation concerning the protection of animals used for experimentation or other scientific purposes.

\subsection{Statistical analysis}

Data are presented as mean \pm SEM. The significance of the differences between group means of hormone levels or receptor activation (luciferase activity) was determined by one-way ANOVA followed by the Holm-Sidak method using SigmaStat 3.5 (Systat Software Inc.). Student $t$-test was performed to determine significant differences between treatments.

\section{Results}

\subsection{Production of recombinant sea bass GTHs and biochemical properties}

Dimeric or single-chain recombinant sea bass GTHs have been produced and efficiently secreted in two systems, insect (Sf9) and mammalian (CHO) cells, as detailed in Materials and Methods. Culture media from Sf9 infections and $\mathrm{CHO}$ selected clones were concentrated by ultrafiltration (Table 
1) and analyzed for recombinant proteins. To identify and characterize the biochemical properties of the secreted hormones, a Western blot analysis was performed. After SDS-PAGE and immunoblotting of the medium containing the sea bass Sf9-Fsh or Sf9-Lh, two proteins of different molecular mass could be visualized. In the case of recombinant Sf9-Fsh, the anti-mFshb and anti-sea bass Cga reacted with proteins of approximately $12 \mathrm{kDa}$ and $15.6 \mathrm{kDa}$, respectively. Both recombinant subunits were slightly smaller than the native forms purified from sea bass pituitary (Fig. 2, A and B). For recombinant Sf9-Lh, the anti-sea bass Lhb and anti-sea bass Cga reacted with proteins of approximately $22 \mathrm{kDa}$ and $15.6 \mathrm{kDa}$, respectively (Fig. 2, E and F). As expected, because of the larger number of amino acids, the recombinant Sf9-Lhb showed a larger size than the Sf9-Fshb. When the $\beta$ subunits were individually expressed in Sf9 cells, only Lhb was secreted and detected in the culture media (Fig. 2E), whereas Fshb remained in the infected cells, because a strong band was detected in the cell lysates but not in the culture medium (Fig. 2A).

Concerning the production of the Fsh dimer in $\mathrm{CHO}$ cells, anti-mFshb and anti-sea bass Cga reacted with two proteins of a similar size (approximately $27 \mathrm{kDa}$ and approximately $24 \mathrm{kDa}$, respectively; Fig. 2, I and J). Both subunits were bigger than the Sf9-Fsh and native sea bass Fsh subunits. The Western blot analysis of culture medium from $\mathrm{CHO}$ cells producing singlechain Fsh or Lh revealed proteins reacting with the anti-mFshb (Fig. 2K) and anti-sea bass Lhb (Fig. 2L) with sizes of roughly 38 and $48 \mathrm{kDa}$, respectively, which would be in the range expected for the linked subunits.

The size differences found in the recombinant subunits depending on the expression system are most likely due to the degree and type of glycosylation. A deglycosylation treatment with $N$-glycosidase $\mathrm{F}$ was performed to confirm this aspect. The enzymatic treatment, which hydrolyzes all types of $\mathrm{N}$-glycan chains, resulted in a decrease in size of both subunits of the recombinant Fsh and Lh dimers (Fig. 2, C, D, and J, and G and H, respectively). The observed reduction in size clearly shows that in both expression systems, the recombinant subunits were $N$-glycosylated, and thus the differences in molecular mass between Sf9-Fsh and CHO-Fsh were due to a greater glycosylation degree in the $\mathrm{CHO}$ cells.

The levels of recombinant Sf9-Lh and Sf9-Lhb secreted to the culture media by coinfected and infected Sf9 cells were $2.8 \mu \mathrm{g} / \mathrm{ml}$ and $2.2 \mu \mathrm{g} / \mathrm{ml}$, respectively, whereas the production of CHO-scLh was $0.03 \mu \mathrm{g} / \mathrm{ml}$, as quan- 

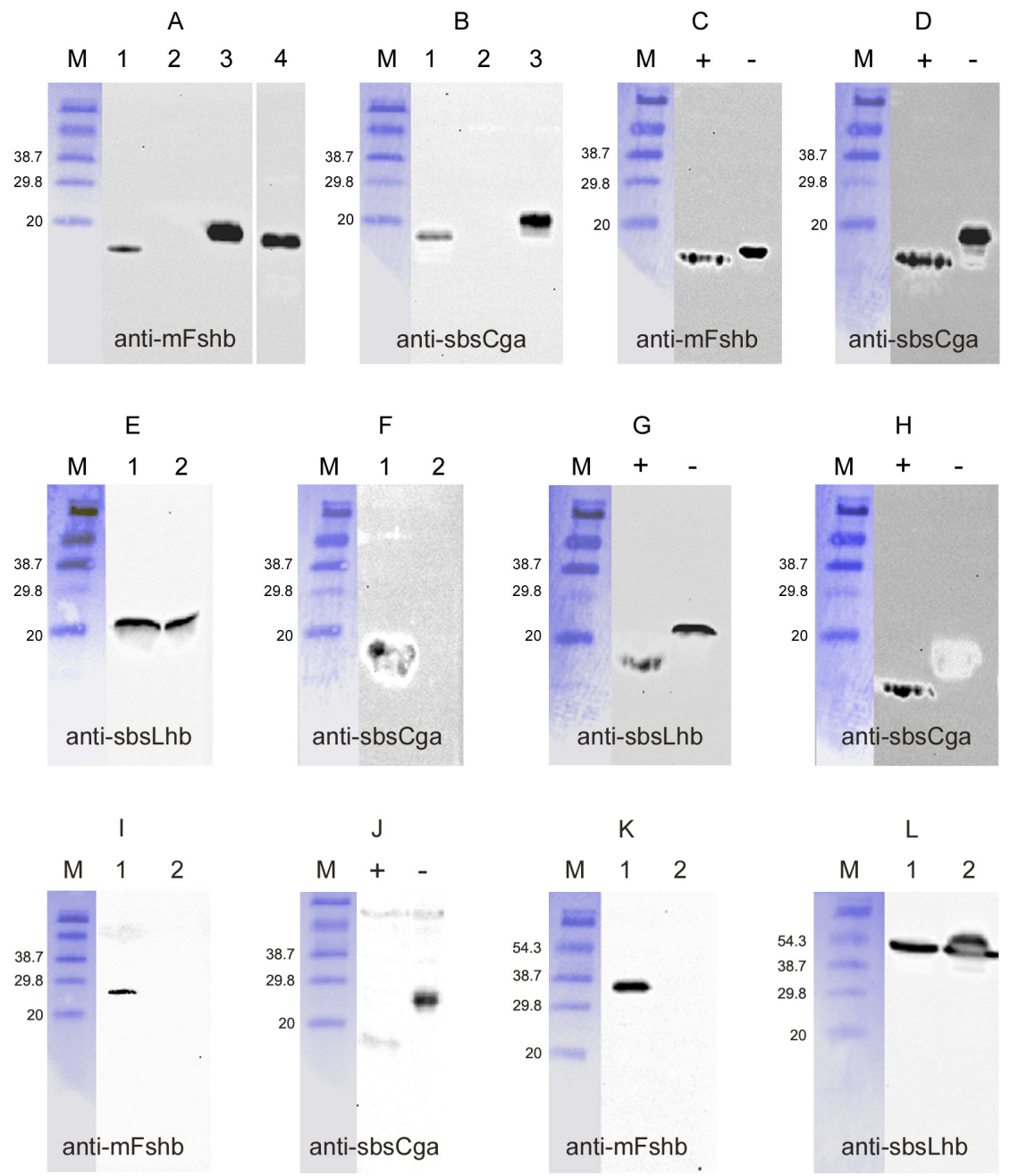

Figure 2. Western blot analysis of recombinant GTHs. Proteins in culture medium (CM) from cells producing different recombinant forms were electrophoresed and incubated with specific antibodies. Analysis of Sf9-Fsh (A-D). A and B) Lane 1: CM from Sf9 cells producing Fsh dimer; lane 2: CM from Sf9 cells producing Fshb subunit; lane 3: purified native sea bass Fsh; lane 4: cell lysates from Sf9 producing Fshb subunit. C and D) Lane +: Sf9-Fsh deglycosylated; Lane -: Sf9-Fsh nondeglycosylated. Analysis of Sf9-Lh (E-H). E and F) Lane 1: CM from Sf9 cells producing Lh dimer; lane 2: CM from Sf9 cells producing Lhb subunit. G and H) Lane + : Sf9-LH deglycosylated; lane - : Sf9-Lh nondeglycosylated. Analysis of CHO-Fsh, CHO-scFsh and $\mathrm{CHO}$-scLh (I-L). I) Lane 1: CM from $\mathrm{CHO}$ cells producing Fsh dimer; Lane 2: CM from control CHO cells. J) Lane + : CHO-Fsh deglycosylated; lane - : CHO-Fsh nondeglycosylated. K) Lane 1: CM from $\mathrm{CHO}$ cells producing scFsh; lane 2: CM from control CHO cells. L) Lanes 1 and 2: CM from CHO cells producing scLh. M: Bio Rad prestained SDS-PAGE broad range molecular weight marker. 
tified by ELISA. On the other hand, the production level of recombinant sea bass Fshs was estimated by using two different methods: an immunodot blot assay using anti-mFshb antisera and an in vitro bioassay using a recombinant sea bass Fshr. This approach allowed us to assess both quantity and bioactivity for each preparation. For both methods, serial dilutions of purified native sea bass Fsh were used as standard. According to the immunodot blot, the level of Sf9-Fsh production was $24.8 \mu \mathrm{g} / \mathrm{ml}$, whereas the levels of CHO-Fsh and CHO-scFsh were $0.650 \mu \mathrm{g} / \mathrm{ml}$ and $0.405 \mu \mathrm{g} / \mathrm{ml}$, respectively. According to the activation of sbsFshr, when compared with the bioactivities of native sea bass Fsh, the Sf9-Fsh production was $4.12 \mu \mathrm{g} / \mathrm{ml}$, whereas CHO-Fsh and CHOscFsh production was $0.011 \mu \mathrm{g} / \mathrm{ml}$ and $0.1 \mu \mathrm{g} /$ $\mathrm{ml}$, respectively (Table 1 ).

\subsection{Bioactivity and specific receptor (Fshr and Lhr) activation}

The bioactivity and specificity of the recombinant sea bass Fsh and Lh were analyzed by determination of their capacity to stimulate intracellular cAMP production in HEK 293 cells stably expressing sea bass Fshr or Lhr. Recombinant dimers (Sf9-Fsh, CHO-Fsh, and Sf9-Lh) and single-chain GTHs (CHO-scFsh and CHO-scLh) activated their corresponding receptors in a dose-dependent manner. Additionally, the $\beta$ subunits obtained from infections with baculovirus Fshb or Lhb were unable to stimulate their cognate receptors (Fig. 3, A and B), demonstrating that only the dimers are bioactive. Dilutions of culture medium from the different expression systems (Sf9 and $\mathrm{CHO}$ cells) were used to stimulate the respective receptors. The minimal concentration of culture medium able to induce cAMP production significantly was 1:1000 for Sf9-Fsh and Sf9-Lh (Fig. 3, A and B), 1:10 for CHO-Fsh and CHO-scLh (Fig. 3, C and D), and 1:100 for CHO-scFsh (Fig. $3 \mathrm{C})$. In all cases, the maximal induction obtained was 22 - to 30 -fold the basal value. To evaluate ligand receptor specificity for the sea bass GTHs, all of the recombinant hormones were used to activate both sea bass GTH receptors, sbsFshr and sbsLhr. None of the GTHs showed cross-receptor binding at any of the concentrations tested because they were only able to stimulate their cognate receptors (Fig. 3, A-D).

To expand our knowledge of ligand recognition by the sea bass GTH receptors, heterologous human GTHs (hFSH and hCG) were tested and compared with the homologous hormones. Interestingly, hFSH was able to 


\section{Fshr}
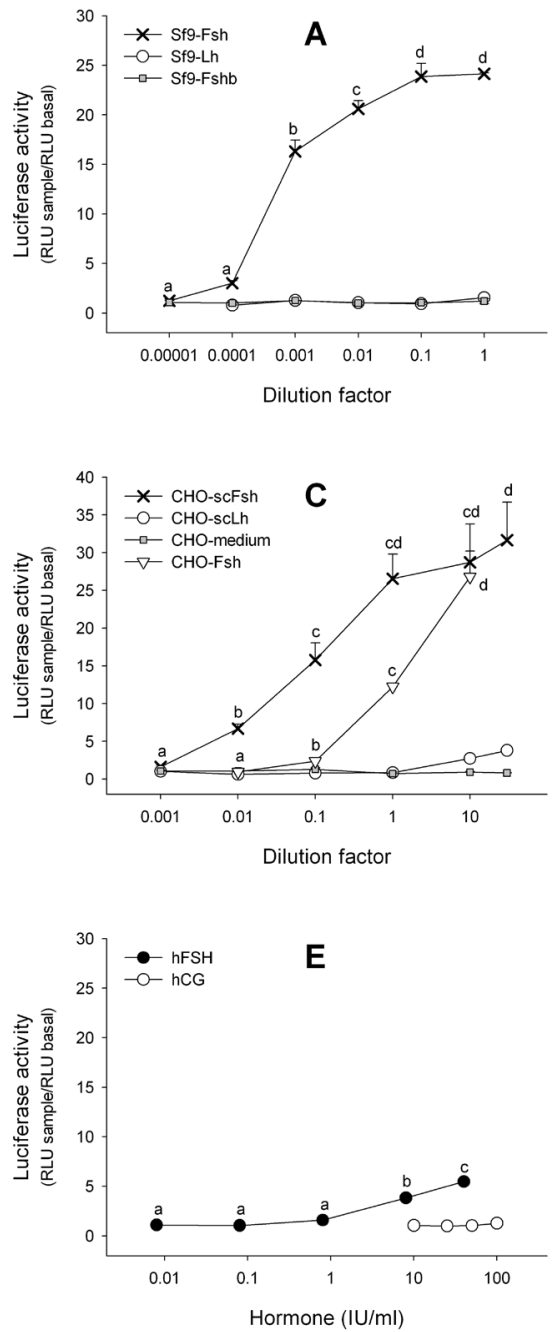

Lhr
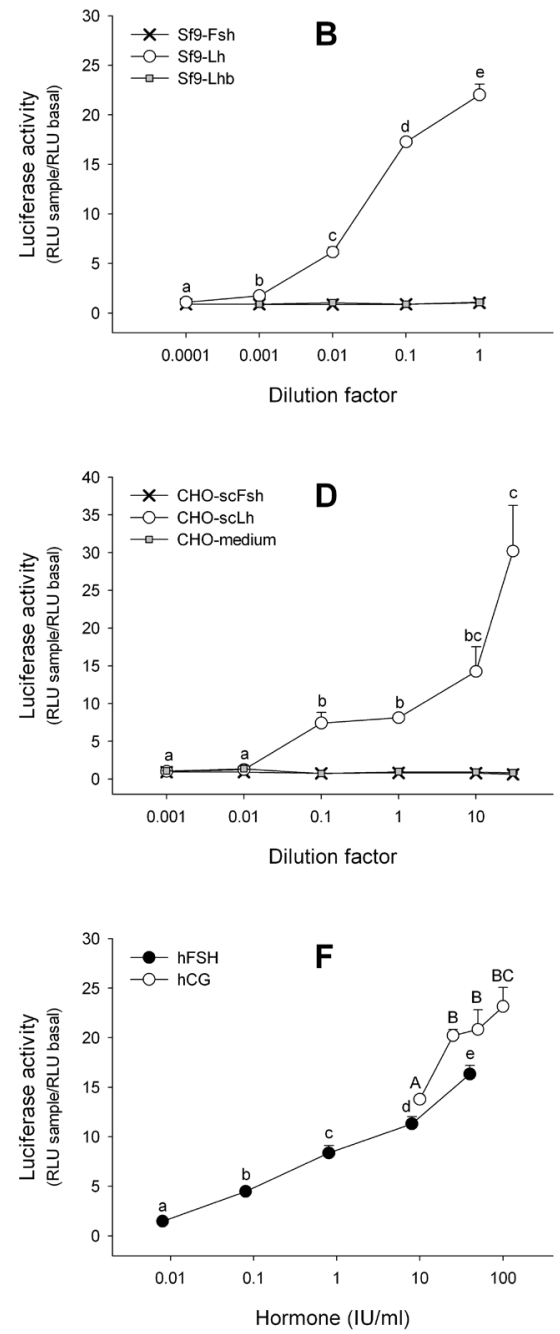

Figure 3. Activation of sea bass Fshr (A, C and E) and Lhr (B, D and F) by sea bass and human GTHs. HEK 293 cells expressing the GTH receptors were incubated with increasing doses of GTHs. The concentration is expressed as dilution factor of the culture medium for sea bass recombinant GTHs (A-D) or international units per milliliter for human GTHs (E and F). Sf9-Fshb, Sf9-Lhb or wild-type CHO conditioned concentrated medium served as control. Each point represents mean \pm SEM of three determinations. Each experiment was repeated at least three times. RLU, relative light units. Different letters indicate significant differences between doses. 
stimulate the sbsLhr in a dosedependent manner (Fig. 3F) but not the sbsFshr, although a slight stimulation was observed when high doses (8-40 IU/ $\mathrm{ml}$ ) were used (Fig. 3E). On the other hand, hCG activated the sbsLhr (Fig. 3F) but not the sbsFshr (Fig. 3E).

To compare the biopotency of Fsh dimer proteins produced by each expression system ( $\mathrm{Sf} 9$ and $\mathrm{CHO}$ cells) with that of the native sea bass Fsh, which is the only available GTH purified from sea bass pituitary glands, we calculated the $\mathrm{EC}_{50}$ to induce cAMP-dependent luciferase expression of
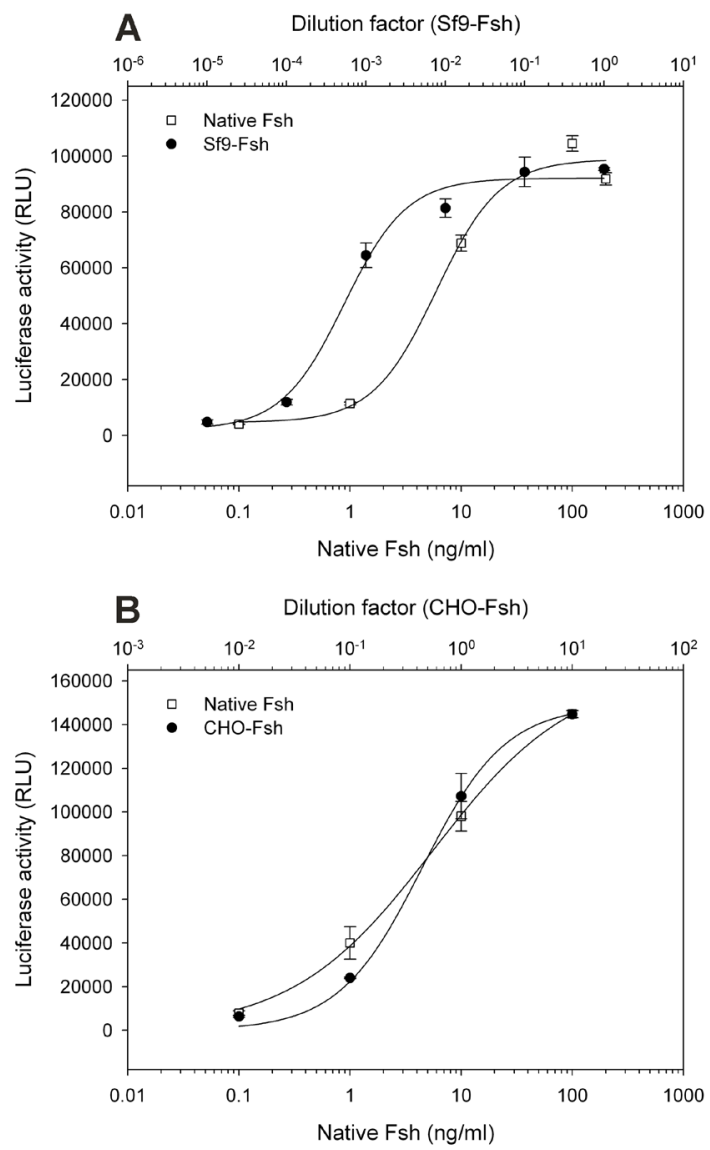

Figure 4. Parallelism of dose-response curves and comparative bioactivity of recombinant Fsh dimers with native sea bass Fsh. HEK 293 cells expressing the sea bass Fshr were incubated with increasing doses of native sea bass Fsh, Sf9-Fsh (A) and CHO-Fsh (B). Each point represents mean \pm SEM of three determinations. RLU, relative light units. 
Table 2. Bioactivities of the recombinant Fshs.

\begin{tabular}{lrl}
\hline Hormone & EC $_{\mathbf{5 0}}$ & B:I ratio \\
\hline & & \\
Sf9-Fsh & $23 \mathrm{ng} / \mathrm{ml}$ & 0.16 \\
CHO-Fsh & $260 \mathrm{ng} / \mathrm{ml}$ & 0.017 \\
CHO-scFsh & $14 \mathrm{ng} / \mathrm{ml}$ & 0.25 \\
Pituitary Fsh & $6 \mathrm{ng} / \mathrm{ml}$ & \\
& &
\end{tabular}

each recombinant sea bass Fsh and that obtained with different doses of native sea bass Fsh. The Sf9-Fsh was approximately 11-fold more potent $\left(\mathrm{EC}_{50}\right.$ $=23 \mathrm{ng} / \mathrm{ml})$ than the CHO-Fsh $\left(\mathrm{EC}_{50}=260 \mathrm{ng} / \mathrm{ml}\right)$, and both were approximately 4- and 43-fold less potent than purified pituitary Fsh $\left(\mathrm{EC}_{50}=6 \mathrm{ng}\right.$ / $\mathrm{ml}$ ), respectively (Fig. 4, A and B). However, when the CHO-scFsh was analyzed $\left(\mathrm{EC}_{50}=14 \mathrm{ng} / \mathrm{ml}\right)$, the $\mathrm{EC}_{50}$ was in the same range as that of the Sf9-Fsh and was 18 -fold more potent than the $\mathrm{CHO}-\mathrm{Fsh}$. Moreover, with the measurement of both Fsh quantity (immunodot blot) and bioactivity (bioassay), the B:I could be estimated. The Sf9-Fsh and CHO-scFsh exhibited similar $\mathrm{B}: \mathrm{I}$ ratios $(0.16$ and 0.25 , respectively), whereas the B:I ratio estimated for CHO-Fsh (0.017) was about 10-fold lower (Table 2). This indicated a higher bioactivity for the baculovirus derived and the single-chain Fshs and supports the $\mathrm{EC}_{50}$ results mentioned above.

\subsection{In vitro bioactivity in gonad culture}

To determine the activity of sea bass recombinant GTHs on the target tissue, their ability to induce steroidogenesis and/or maturation in sea bass ovary and testis was tested. Preliminary in vitro experiments using several doses of sea bass recombinant GTHs (data not shown) showed a clear dosedependent effect on E2 production by ovarian tissue. In further experiments, only two doses of all recombinant dimers (Sf9-Fsh, CHO-Fsh, and Sf9-Lh) were used. The stimulatory effects of recombinant sea bass Fsh (Sf9 and $\mathrm{CHO}$ ) and Lh (Sf9) dimers were analyzed in adult sea bass ovary during the early and mid vitellogenic stages (October to November), and all of them showed a dose-dependent effect on E2 secretion (Fig. 5A). We observed that equivalent concentrations of Sf9-Fsh and Sf9-Lh in the range of $250 \mathrm{ng} /$ $\mathrm{ml}$ had a similar effect in ovary E2 production. In testis of adult male sea 

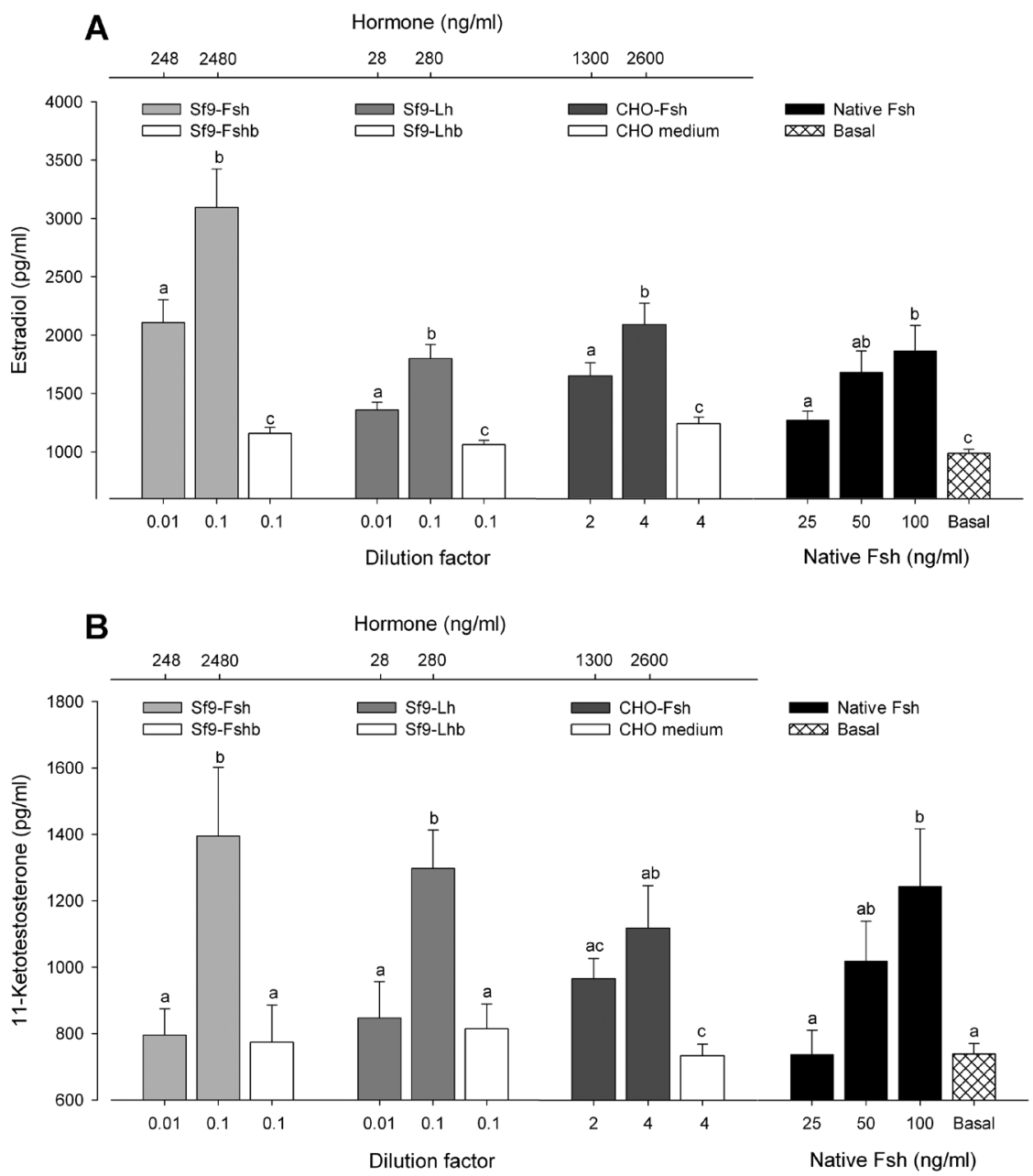

Figure 5. In vitro effects of recombinant GTH dimers on E2 (A) and 11-KT (B) production by sea bass ovary and testis, respectively. Tissue fragments were incubated with two doses of each recombinant GTH. In parallel, the effect of purified native Fsh in the same tissue is shown. The upper axis shows the concentrations used calculated by immunoassay (Lh ELISA and Fsh immunodot blot). Each bar represents mean \pm SEM of four determinations. Each experiment was repeated three times. Different letters indicate significant differences between doses.

bass, the 11-KT secretion during late spermatogenesis (October to November) was evaluated. The analysis showed that $280 \mathrm{ng} / \mathrm{ml} \mathrm{Sf9-Lh}$ was able to stimulate 11-KT production in testis, whereas a concentration of Sf9-Fsh 10 times higher $(2.480 \mathrm{ng} / \mathrm{ml})$ was needed to obtain the same effect (Fig. 
5B). When comparing the steroid production between Sf9-Fsh and CHOFsh treatments, the results were consistent with those calculated for the $\mathrm{EC}_{50}$, and equivalent immunologically detected concentrations in the range of $2500 \mathrm{ng} / \mathrm{ml}$ had different potency. The ability of single-chain proteins to induce E2 production and maturation in vitelogenic and postvitellogenic oocytes was also analyzed. The scFsh was effective to induce E2 production in a dose-dependent manner (Fig. 6A), and scLh was able to increase the percentage of maturing oocytes compared with $\mathrm{CHO}$ medium (Fig. 6B).
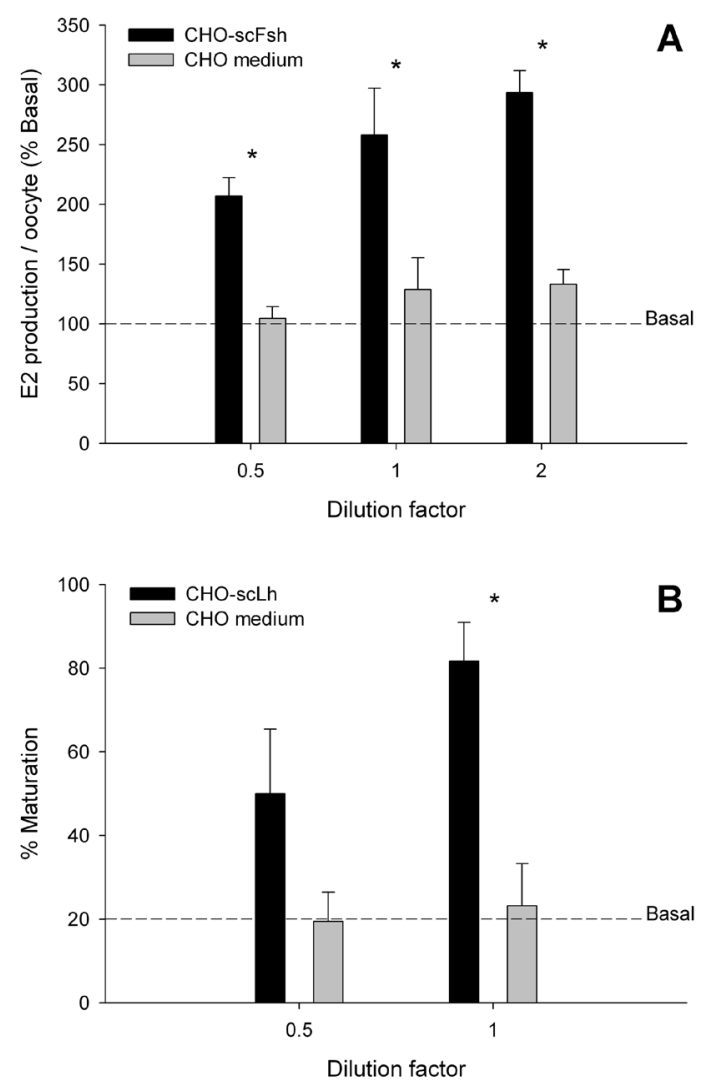

Figure 6. In vitro effects of recombinant single-chain Fsh and Lh on E2 production (A) and the percentage of maturation induction (B), respectively, by sea bass oocytes. Estrogen production is expressed by oocyte and percentage with respect to basal levels. Each bar represents mean \pm SEM of $3(\mathrm{~A})$ and 30 (B) determinations, and each experiment was repeated three and two times respectively. Asterisks represent significant differences from the control (CHO medium). 


\subsection{In vivo half-life evaluation}

Those GTH preparations showing the highest in vitro biopotency were used to evaluate their in vivo stability, allowing the comparison of recombinant hormones produced in two systems, Sf9 and $\mathrm{CHO}$, which generate different glycosylation patterns. Single intramuscular injections with recombinant Fsh (Sf9-Fsh vs. CHO-scFsh) or Lh (Sf9-Lh vs. CHO-scLh) were performed, plasma was collected at designated intervals $(0,6,12,24,48$, and $72 \mathrm{~h}$ ) after injection, and GTH levels were analyzed by bioassay (Fsh) or ELISA (Lh). Plasma concentration-time curves for Sf9-Lh and CHO-scLh are illustrated in Figure 7A. The analysis showed that Sf9-Lh is rapidly cleared from circulation, with a clearance rate of $3.16 \mathrm{ml} / \mathrm{h}$. Six hours after Sf9-Lh injection, Lh levels were slightly greater (2.1-fold) than before the injection (t0), whereas Lh levels of CHO-scLh injected animals were approximately 11-fold higher than at t0 and were maintained significantly high until $48 \mathrm{~h}$ (Fig. 7A). Accordingly, the clearance rate of CHO-scLh was 40 times lower than that of Sf9-Lh $(0.079 \mathrm{ml} / \mathrm{h}$ vs. $3.16 \mathrm{ml} / \mathrm{h})$. Because very low levels of the Lh produced by the insect cells could be detected already at $6 \mathrm{~h}$ after injection, another injection of $1000 \mathrm{ng}$ of Sf9-Lh was performed to further determine whether Sf9-Lh entered circulation or was degraded before. Blood samples were collected at $0,0.5,1,3$, and $6 \mathrm{~h}$ after injection. High levels of Lh were already bioavailable at $0.5 \mathrm{~h}$, declining rapidly during the next $6 \mathrm{~h}$ (Fig. 7A, inset). The calculation of the clearance rate rendered a value of 6.5 $\mathrm{ml} / \mathrm{h}$, which is in the range but further rises the one calculated before.

Regarding Fsh, the injection of either recombinant hormone, Sf9-Fsh or $\mathrm{CHO}$-scFsh, led to an increase in Fsh plasma levels at $6 \mathrm{~h}$ after injection and decreased gradually in the next hours. $\mathrm{CHO}$-scFsh showed a more prolonged life in circulation than Sf9-Fsh, as high levels of $\mathrm{CHO}$-scFsh could be detected until $72 \mathrm{~h}$ after injection, whereas Sf9-Fsh was cleared just in $24 \mathrm{~h}$ (Fig. 7, B and C). Both the mammalian- and the insect-derived Fshs were more stable than the corresponding recombinant Lhs (Fig. $7 \mathrm{C}$ ), and could be detected longer in circulation.

\section{Discussion}

In the present study, bioactive recombinant sea bass Fsh and Lh proteins were successfully produced using two different expression systems, insect 
(Sf9) and mammalian (CHO) cells.

In both systems, dimer and single-chain sea bass Fsh and Lh were efficiently expressed and secreted, although the production levels obtained in the baculovirus system were considerably higher than those obtained through stable transfection of $\mathrm{CHO}$ cells. The levels of recombinant Sf9Lh produced were comparable to those reported by other authors in the production of fish and mammalian GTHs using this system [36-38]. Regarding the production levels of Sf9-Fsh, CHO-Fsh, and $\mathrm{CHO}$-scFsh, the combined use of an immunodot blot and an in vitro bioassay specific for sea bass Fsh allowed the evaluation of the relative bioactivity of concrete amounts of recombinant protein produced. These assays permitted us to assess protein production levels and to compare the bioactivities of the different recombinant dimer Fsh forms. The data reported here clearly showed a higher production of Sf9-Fsh than that of $\mathrm{CHO}$-Fsh. When we analyzed the potency and B:I ratio, Sf9-Fsh was more bioactive than CHO-Fsh but oddly less than $\mathrm{CHO}$-scFsh. These different bioactivities of the recombinant GTHs could be due to a different degree and type of glycosylation according to the expression system used [39-41]. Insect cells produce glycoproteins containing high mannose-type oligosaccharides. In contrast, mammalian cells are able to express glycoproteins with complex sialylated oligosaccharides [42]. Functionally, GTH isoforms containing more sialylated oligosaccharides are less biopotent, as has been shown for rat FSH [41] and LH [40]. This information supports our findings that Sf9-Fsh is more bioactive than $\mathrm{CHO}-\mathrm{Fsh}$. In the particular case of $\mathrm{CHO}$-scFsh, the higher B:I ratio might be influenced by other aspects (e.g., being a fusion protein instead of a dimer, which avoids subunit dissociation, or the presence of the CTP that has been shown to increase extracellular stability) $[43,44]$.

When $\beta$ subunits were individually expressed in the baculovirus system, only Sf9-Lhb was readily detectable in the culture medium, whereas Sf9Fshb was only found in the cell lysate. Similar situations have been reported for other recombinant GTH subunits. In a mammalian expression system, recombinant human FSHb and LHb subunits were inefficiently secreted and slowly degraded intracellularly, whereas CGa and hCGb were rapidly secreted [45-47]. In insect cells, recombinant bovine CGa was found in culture medium at 10-fold higher levels than FSHb [48], and recombinant catfish Cga was the only of the three subunits to be successfully produced in abundance as a single subunit [49]. The reason for this behavior is not 

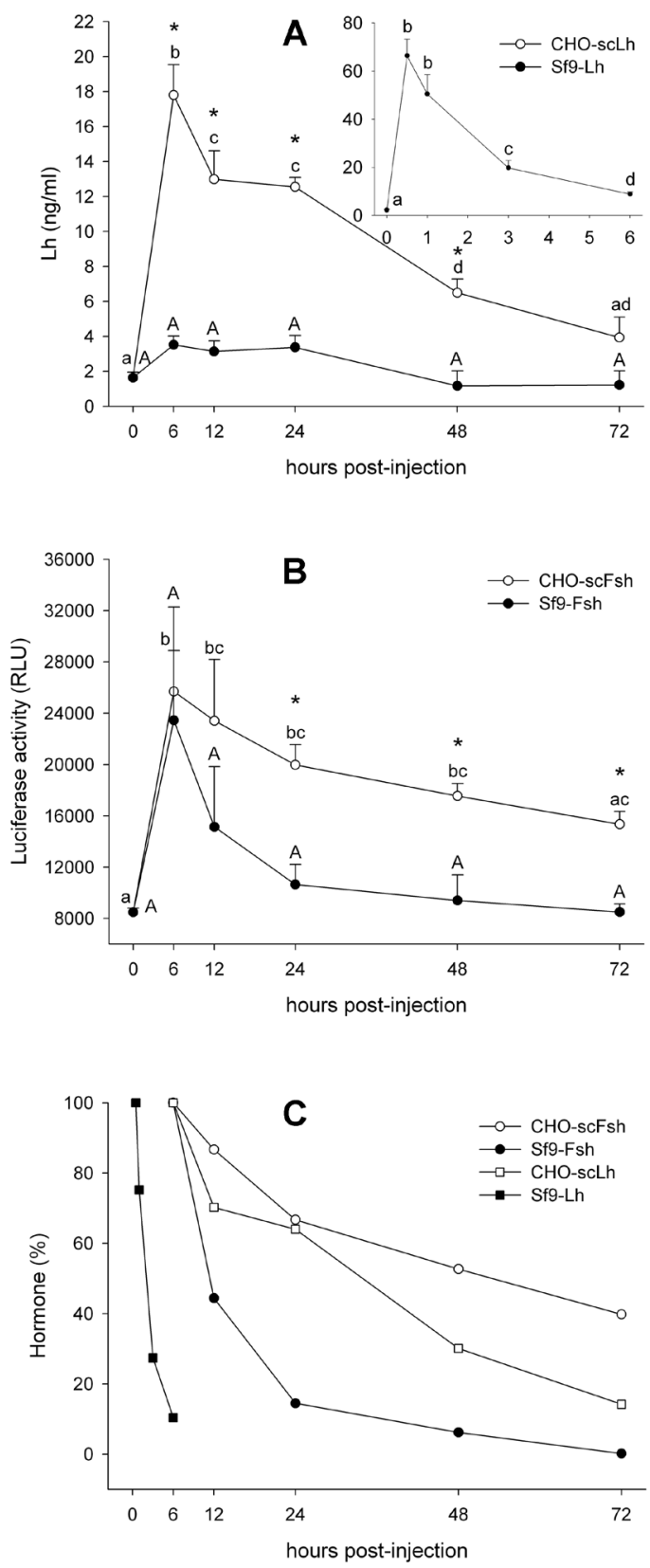

Figure 7. In vivo half-life of recombinant GTHs. Juvenile sea bass were injected with Sf9 and $\mathrm{CHO}$ recombinant GTHs. A) Plasma levels of Sf9-Lh and CHO-scLh at different times after injection. The inset graphic shows plasma levels of Sf9-Lh during the 0-6 $\mathrm{h}$ postinjection period. Lh was determined by specific ELISA. B) Plasma levels of Sf9-Fsh and $\mathrm{CHO}-\mathrm{scF}$ sh at different times after injection. Fsh was determined by bioassay using sbsFshr. C) Clearance rate of injected hormones is presented as percentage of plasma levels at $6 \mathrm{~h}(100 \%)$. For Sf9-Lh, plasma levels at $0.5 \mathrm{~h}$ were taken as $100 \%$. Each point represents mean \pm SEM of 5-10 fish. RLU, relative light units. Different letters indicate significant differences between hours. Asterisks represent significant differences between treatments. 
totally clear, but it is known that proteins that fail to reach their native conformation in the endoplasmic reticulum, orphan subunits, and some heterologously expressed proteins can be selectively retained and later returned to the cytosol, where they are degraded $[50,51]$. Nevertheless, coexpression of both GTH subunits leads to heterodimer assembly and efficient secretion [47-49].

The functionality of the recombinant Fshs and Lhs was initially evaluated through activation of their homologous receptors (Fshr and Lhr). All sea bass recombinant GTHs activated their cognate receptors in a dosedependent manner, showing no cross-activity on a wide range of concentrations. Besides, neither the presence of the CTP included in the single chains nor the His-tag of the Fsh dimers influenced hormone receptor binding specificity. Selective ligand-receptor interactions, which are well established in mammals, have been also described for rainbow trout by using species-specific gonadotropins [22], and amago salmon receptors by using the ligands from a closely related species [21]. Opposite to the sea bass and rainbow trout situation, in most of the fish species analyzed, promiscuous Fshr-Lh interactions have been observed in addition to the cognate ligand-receptor pairs [38], although the structural basis or physiological significance of this promiscuity is still unclear. When human GTHs were used to activate the sea bass receptors, sbsLhr was activated by hCG and hFSH with nearly the same potency, whereas the sbsFshr scarcely responded to hFSH. This behavior of the human GTHs on the sea bass receptors is the same as that found for the bovine GTHs [20]. The same promiscuous behavior was observed in zebrafish, amago salmon, and African catfish Lhrs $[18,19,52]$ when using mammalian GTHs. The promiscuous response of the sbsLhr to mammalian FSHs (hFSH and bFSH) but not to sea bass Fsh could have its basis in the higher similarity in sequence and structure of mammalian FSHs to sea bass Lh than to sea bass Fsh, as we previously proposed [20]. On the other hand, the very weak response of sbsFshr to hFSH, together with the fact that many residues described as important for hFSH/hFSHR binding [53] are lacking in sea bass [20], or that specificity determinants in fish $\beta$ subunits are not related to charge differences as in mammals [54], would recommend caution when using mammalian models to explain fish Fsh-receptor interactions.

In this study, all recombinant sea bass GTHs were able to induce steroid production in cultured ovarian and testis fragments. Sf9-Fsh and Sf9Lh had a similar effect in stimulating E2 production in the ovary, whereas 
in testis, Sf9-Lh was more potent in stimulating 11-KT production. Other studies using recombinant fish GTHs also showed that both Fsh and Lh were able to stimulate in vitro steroid synthesis, albeit with different potencies. In red seabream, as in sea bass, Lh was also more effective than Fsh in stimulating 11-KT release [55]. In coho salmon, Lh was progressively more potent than Fsh in stimulating 11-KT production as spermatogenesis progressed through stage IV [56]. However, in zebrafish and channel catfish, recombinant Fsh was more effective in stimulating androgen release than Lh $[49,57]$; and in African catfish testis, the amount of Fsh needed to obtain a significant steroid release was lower than that of Lh [58]. These different responses could be based on the developmental stage of the gonadal tissue, and therefore in the presence of the corresponding GTH receptors. In zebrafish it has been suggested that the higher levels of $f$ shr expression could explain the higher potency of Fsh [57]. In our study, the cultured testes were in late spermatogenesis, and there is no difference in GTH receptor expression at that gonadal stage [59]. Although in teleosts both GTHs are steroidogenic, further research is needed to elucidate the differential role of each hormone in each spermatogenic stage.

Before undertaking any in vivo functional experiment, it is essential to gain knowledge on the in vivo pharmacokinetics of the recombinant GTHs. Other studies in fish had suggested that insect-produced GTHs could be rapidly cleared from circulation $[13,60]$, but this has not been demonstrated or quantified. In this report, $\mathrm{CHO}$-scGTHs showed a higher stability in plasma than Sf9-GTHs, which could be based in their different glycosylation because the content in terminal sialic acid residues can be a determinant for the rate at which glycoproteins are cleared from circulation $[40,41,61]$. The fusion of the two subunits and the presence of $O$-linked oligosaccharides in the CTP may additionally contribute to prolonging the circulating halflife of the scGTHs $[43,44,62]$. The reason for the highest stability of Fsh compared with Lh in both systems is unknown. A relationship between the stability and the physiological role of the hormones could be hypothesized. Maintained high levels of Fsh in the bloodstream would be necessary for long-term stimulation of gonadal growth, whereas short-term increases in plasma Lh would have a more specific effect in a certain phase of the reproductive cycle and should be cleared more quickly.

In conclusion, although heterologous GTHs may bind to fish GTH receptors, their physiological effects could not reproduce exactly those of 
homologous hormones. Thus, the production of homologous recombinant GTHs is a fundamental tool for studies on the physiology of GTHs and the development of biotechnological applications. In this study we have produced potent recombinant sea bass FSHs and LHs that mimic the natural hormones and can be used in future studies of this species. The baculovirus system is more efficient than mammalian expression systems in terms of large amounts of production, necessary to develop different detection assays (production of antibodies and standards). Because of its high potency, it is also attractive for in vitro structure-function studies of recombinant GTH analogs. However, the data obtained in vivo show a rapid clearance of the insect-produced proteins in contrast with those produced by mammalian cells. Thus, recombinant CHO-GTHs, in particular single-chain GTHs in combination with CTP, seem to be better candidates for in vivo experiments because of their increased half-life.

\section{Acknowledgments}

We thank Dr. A. Shimizu from the National Research Institute of Fisheries Science (Yokohama, Japan) for supplying the antisera against a synthetic peptide of mummichog Fshb subunit; Dr. Irving Boime (Washington University, St. Louis, $\mathrm{MO}$ ), for supplying an expression plasmid containing the $h C G b$ that was used for amplification of the CTP. To the National Institute of Diabetes and Digestive and Kidney Diseases' National Hormone \& Peptide Program; and A.F. Parlow for providing human FSH.

\section{References}

1. Pierce JG, Parsons TF. Glycoprotein hormones: structure and function. Annu Rev Biochem 1981; 50:465-495.

2. Bousfield GR, Perry WM, Ward DN. Gonadotropins. Chemistry and biosynthesis. In: Knobil E, Neill JD (eds.), The Physiology of Reproduction. New York: Raven Press; 1994:1749-1792.

3. Fiddes JC, Talmadge K. Structure, expression, and evolution of the genes for the human glycoprotein hormones. Recent Prog Horm Res 1984; 40:43-78.

4. Yaron Z, Gur G, Melamed P, Rosenfeld H, Elizur A, Levavi-Sivan B. Regulation of fish gonadotropins. Int Rev Cytol 2003; 225:131-185.

5. Swanson P, Dickey JT, Campbell B. Biochemistry and physiology of fish gonadotropins. Fish Physiol Biochem 2003; 28:53-59.

6. Yaron Z, Sivan B. Reproduction. In: Evans DH, Claibourne JB (eds.), The Physiology of 
Fishes. Boca Raton: CRC Press; 2006:343-386.

7. Kamei H, Ohira T, Yoshiura Y, Uchida N, Nagasawa H, Aida K. Expression of a biologically active recombinant follicle stimulating hormone of Japanese Eel Anguilla japonica using methylotropic yeast, Pichia pastoris. Gen Comp Endocrinol 2003; 134:244-254.

8. Vischer HF, Granneman JC, Linskens MH, Schulz RW, Bogerd J. Both recombinant African catfish $\mathrm{LH}$ and FSH are able to activate the African catfish FSH receptor. J Mol Endocrinol 2003; 31:133-140.

9. Morita T, Yoshizaki G, Kobayashi M, Watabe S, Takeuchi T. Fish eggs as bioreactors: the production of bioactive luteinizing hormone in transgenic trout embryos. Transgenic Res 2004; 13:551-557.

10. So WK, Kwok HF, Ge W. Zebrafish gonadotropins and their receptors: II. Cloning and characterization of zebrafish follicle-stimulating hormone and luteinizing hormone subunits-their spatial-temporal expression patterns and receptor specificity. Biol Reprod 2005; 72:1382-1396.

11. Kobayashi M, Morita T, Ikeguchi K, Yoshizaki G, Suzuki T, Watabe S. In vivo biological activity of recombinant goldfish gonadotropins produced by baculovirus in silkwonn larvae. Aquaculture 2006; 256:433-442.

12. Cui M, Li W, Liu W, Yang K, Pang Y, Haoran L. Production of recombinant orangespotted grouper (Epinephelus coioides) luteinizing hormone in insect cells by the baculovirus expression system and its biological effect. Biol Reprod 2007; 76:74-84.

13. Kazeto Y, Kohara M, Miura T, Miura C, Yamaguchi S, Trant JM, Adachi S, Yamauchi K. Japanese eel follicle-stimulating hormone (Fsh) and luteinizing hormone (Lh): production of biologically active recombinant Fsh and Lh by Drosophila S2 cells and their differential actions on the reproductive biology. Biol Reprod 2008; 79:938-946.

14. Mittelholzer C, Andersson E, Taranger GL, Consten D, Hirai T, Senthilkumaran B, Nagahama Y, Norberg B. Molecular characterization and quantification of the gonadotropin receptors FSH-R and LH-R from Atlantic cod (Gadus morhua). Gen Comp Endocrinol 2009; 160:47-58.

15. Ascoli M, Fanelli F, Segaloff DL. The lutropin/choriocrctnadotropin receptor, a 2002 perspective. Endocr Rev 2002; 23:141-174.

16. Dias JA, Cohen BD, Lindau-Shepard B, Nechamen CA, Peterson AJ, Schmidt A. Molecular, structural, and cellular biology of follitropin and follitropin receptor. Vitam Horm 2002; 64:249-322.

17. Oba Y, Hirai T, Yoshiura Y, Yoshikuni M, Kawauchi H, Nagahama Y. The duality of fish gonadotropin receptors: cloning and functional characterization of a second gonadotropin receptor cDNA expressed in the ovary and testis of amago salmon (Oncorhynchus rhodurus). Biochem Biophys Res Commun 1999; 265:366-371.

18. Oba Y, Hirai T, Yoshiura Y, Yoshikuni M, Kawauchi H, Nagahama Y. Cloning, functional characterization, and expression of a gonadotropin receptor cDNA in the ovary and testis of amago salmon (Oncorhynchus rhodurus). Biochem Biophys Res Commun 1999; 263:584-590.

19. Kwok HF, So WK, Wang Y, Ge W. Zebrafish gonadotropins and their receptors: I. Cloning and characterization of zebrafish follicle-stimulating hormone and luteinizing hormone receptors-evidence for their distinct functions in follicle development. Biol Reprod 2005; 72:1370-1381.

20. Rocha A, Gomez A, Zanuy S, Cerda-Reverter JM, Carrillo M. Molecular characteriza- 
tion of two sea bass gonadotropin receptors: cDNA cloning, expression analysis, and functional activity. Mol Cell Endocrinol 2007; 272:63-76.

21. Ko H, Park W, Kim DJ, Kobayashi M, Sohn YC. Biological activities of recombinant Manchurian trout FSH and LH: their receptor specificity, steroidogenic and vitellogenic potencies. J Mol Endocrinol 2007; 38:99-111.

22. Sambroni E, Le Gac F, Breton B, Lareyre JJ. Functional specificity of the rainbow trout (Oncorhynchus mykiss) gonadotropin receptors as assayed in a mammalian cell line. J Endocrinol 2007; 195:213-228.

23. Alvariño JMR, Carrillo M, Zanuy S, Prat F, Mañanós E. Pattern of sea bass oocyte development after ovarian stimulation by LHRHa. J Fish Biol 1992; 41:965-970.

24. Carrillo M, Zanuy S, Prat F, Cerda J, Ramos H, Mañanós E, Bromage N. Sea bass. In: Bromage NR, Roberts J (eds.), Broodstock Management and Egg and Larval Quality. London: Blackwell Science; 1995:138-168.

25. Asturiano JF, Sorbera LA, Ramos J, Kime DE, Carrillo M, Zanuy S. Hormonal regulation of the European sea bass reproductive cycle: an individualized female approach. J Fish Biol 2000; 56:1155-1172.

26. Molés G, Gomez A, Rocha A, Carrillo M, Zanuy S. Purification and characterization of follicle-stimulating hormone from pituitary glands of sea bass (Dicentrarchus labrax). Gen Comp Endocrinol 2008; 158:68-76.

27. Horton RM, Hunt HD, Ho SN, Pullen JK, Pease LR. Engineering hybrid genes without the use of restriction enzymes - gene-splicing by overlap extension. Gene 1989; 77:61-68.

28. Ho SN, Hunt HD, Horton RM, Pullen JK, Pease LR. Site-directed mutagenesis by overlap extension using the polymerase chain-reaction. Gene 1989; 77:51-59.

29. Schatz SM, Kerschbaumer RJ, Gerstenbauer G, Kral M, Dorner F, Scheiflinger F. Higher expression of Fab antibody fragments in a $\mathrm{CHO}$ cell line at reduced temperature. Biotechnol Bioeng 2003; 84:433-438.

30. Mateos J, Mañanós E, Swanson P, Carrillo M, Zanuy S. Purification of luteinizing hormone (LH) in the sea bass (Dicentrarchus labrax) and development of a specific immunoassay. Cienc Mar 2006; 32:271-283.

31. Shimizu A, Yamashita M. Purification of mummichog (Fundulus heteroclitus) gonadotropins and their subunits, using an immunochemical assay with antisera raised against synthetic peptides. Gen Comp Endocrinol 2002; 125:79-91.

32. Sorbera LA, Asturiano JF, Carrillo M, Cerda J, Kime DE, Zanuy S. In vitro oocyte maturation in the sea bass: effects of hCG, pituitary extract and steroids. J Fish Biol 1999; 55:9-25.

33. Rodríguez L, Begtashi I, Zanuy S, Carrillo M. Development and validation of an enzyme immunoassay for testosterone: effects of photoperiod on plasma testosterone levels and gonadal development in male sea bass (Dicentrarchus labrax, L.) at puberty. Fish Physiol Biochem 2000; 23:141-150.

34. Cuisset B, Pradelles P, Kime DE, Kuhn ER, Babin P, Davail S, Lemenn F. EnzymeImmunoassay for 11-ketotestosterone using acetylcholinesterase as label - application to the measurement of 11-ketotestosterone in plasma of Siberian sturgeon. Comp Biochem Physiol C Pharmacol 1994; 108:229-241.

35. Rodríguez L, Begtashi I, Zanuy S, Carrillo M. Long-term exposure to continuous light inhibits precocity in European male sea bass (Dicentrarchus labrax, L.): hormonal 
aspects. Gen Comp Endocrinol 2005; 140:116-125.

36. Kato Y, Sato I, Ihara T, Tomizawa K, Mori J, Geshi M, Nagai T, Okuda K, Kato T, Ueda S. Expression and purification of biologically active porcine follicle-stimulating hormone in insect cells bearing a baculovirus vector. J Mol Endocrinol 1998; 20:55-65.

37. Legardinier S, Duonor-Cerutti M, Devauchelle G, Combarnous Y, Cahoreau C. Biological activities of recombinant equine luteinizing hormone/chorionic gonadotropin (eLH/CG) expressed in Sf9 and Mimic insect cell lines. J Mol Endocrinol 2005; $34: 47-60$.

38. Levavi-Sivan B, Bogerd J, Mañanós EL, Gómez A, Lareyre JJ. Perspectives on fish gonadotropins and their receptors. Gen Comp Endocrinol 2010; 165:412-437.

39. Grossmann M, Wong R, Teh NG, Tropea JE, East-Palmer J, Weintraub BD, Szkudlinski MW. Expression of biologically active human thyrotropin (hTSH) in a baculovirus system: effect of insect cell glycosylation on hTSH activity in vitro and in vivo. Endocrinology 1997; 138:92-100.

40. Olivares A, Mendez JP, Cardenas M, Oviedo N, Palomino MA, Santos I, Perera-Marin G, Gutierrez-Sagal R, Ulloa-Aguirre A. Pituitary-testicular axis function, biological to immunological ratio and charge isoform distribution of pituitary LH in male rats with experimental diabetes. Gen Comp Endocrinol 2009; 161:304-312.

41. Ambao V, Rulli SB, Carino MH, Console G, Ulloa-Aguirre A, Calandra RS, Campo S. Hormonal regulation of pituitary FSH sialylation in male rats. Mol Cell Endocrinol 2009; 309:39-47.

42. Kost TA, Condreay JP, Jarvis DL. Baculovirus as versatile vectors for protein expression in insect and mammalian cells. Nat Biotechnol 2005; 23:567-575.

43. Fares FA, Suganuma N, Nishimori K, Lapolt PS, Hsueh AJW, Boime I. Design of a long-acting follitropin agonist by fusing the $\mathrm{C}$-terminal sequence of the chorionicgonadotropin beta-subunit to the follitropin beta-subunit. Proc Natl Acad Sci U S A 1992; 89:4304-4308.

44. Ben-Menahem D, Boime I. Converting heterodimeric gonadotropins to genetically linked single chains: new approaches to structure activity relationships and analogue design. Trends Endocrinol Metab 1996; 7:100-105.

45. Corless CL, Matzuk MM, Ramabhadran TV, Krichevsky A, Boime I. Gonadotropin beta subunits determine the rate of assembly and the oligosaccharide processing of hormone dimer in transfected cells. J Cell Biol 1987; 104:1173-1181.

46. Corless CL, Bielinska M, Ramabhadran TV, Daniels-McQueen S, Otani T, Reitz BA, Tiemeier DC, Boime I. Gonadotropin alpha subunit. Differential processing of free and combined forms in human trophoblast and transfected mouse cells. J Biol Chem 1987; 262:14197-14203.

47. Keene JL, Matzuk MM, Otani T, Fauser BC, Galway AB, Hsueh AJ, Boime I. Expression of biologically active human follitropin in Chinese hamster ovary cells. J Biol Chem 1989; 264:4769-4775.

48. Van de Wiel DF, van Rijn PA, Meloen RH, Moormann RJ. High-level expression of biologically active recombinant bovine follicle stimulating hormone in a baculovirus system. J Mol Endocrinol 1998; 20:83-98.

49. Zmora N, Kazeto Y, Kumar RS, Schulz RW, Trant JM. Production of recombinant channel catfish (Ictalurus punctatus) FSH and LH in S2 Drosophila cell line and an indication of their different actions. J Endocrinol 2007; 194:407-416. 
50. Helenius A, Aebi M. Intracellular functions of N-linked glycans. Science 2001; 291: 2364-2369.

51. Kleizen B, Braakman I. Protein folding and quality control in the endoplasmic reticulum. Curr Opin Cell Biol 2004; 16:343-349.

52. Vischer HF, Bogerd J. Cloning and functional characterization of a gonadal luteinizing hormone receptor complementary DNA from the African catfish (Clarias gariepinus). Biol Reprod 2003; 68:262-271.

53. Fan QR, Hendrickson WA. Structure of human follicle-stimulating hormone in complex with its receptor. Nature 2005; 433:269-277.

54. Vischer HF, Marques RB, Granneman JCM, Linskens MHK, Schulz RW, Bogerd J. Receptor-selective determinants in catfish gonadotropin seatbelt loops. Mol Cell Endocrinol 2004; 224:55-63.

55. Kagawa H, Tanaka H, Okuzawa K, Kobayashi M. GTH II but not GTH I induces final maturation and the development of maturational competence of oocytes of red seabream in vitro. Gen Comp Endocrinol 1998; 112:80-88.

56. Planas JV, Swanson P. Maturation-associated changes in the response of the salmon testis to the steroidogenic actions of gonadotropins (GTH I and GTH II) in vitro. Biol Reprod 1995; 52:697-704.

57. García-López A, de Jonge H, Nóbrega RH, de Waal PP, van Dijk W, Hemrika W, Taranger GL, Bogerd J, Schulz RW. Studies in zebrafish reveal unusual cellular expression patterns of gonadotropin receptor messenger ribonucleic acids in the testis and unexpected functional differentiation of the gonadotropins. Endocrinology 2010; 151:2349-2360.

58. García-López A, Bogerd J, Granneman JC, van Dijk W, Trant JM, Taranger GL, Schulz RW. Leydig cells express follicle-stimulating hormone receptors in African catfish. Endocrinology 2009; 150:357-365.

59. Rocha A, Zanuy S, Carrillo M, Gomez A. Seasonal changes in gonadal expression of gonadotropin receptors, steroidogenic acute regulatory protein and steroidogenic enzymes in the European sea bass. Gen Comp Endocrinol 2009; 162:265-275.

60. Kobayashi M, Hayakawa Y, Park W, Banba A, Yoshizaki G, Kumamaru K, Kagawa H, Kaki H, Nagaya H, Sohn YC. Production of recombinant Japanese eel gonadotropins by baculovirus in silkworm larvae. Gen Comp Endocrinol 2010; 167:379-386.

61. Ulloa-Aguirre A, Maldonado A, Damian-Matsumura P, Timossi C. Endocrine regulation of gonadotropin glycosylation. Arch Med Res 2001; 32:520-532.

62. Klein J, Lobel L, Pollak S, Lustbader B, Ogden RT, Sauer MV, Lustbader JW. Development and characterization of a long-acting recombinant hFSH agonist. Hum Reprod 2003; 18:50-56. 




\title{
Capítulo 6:
}

\section{Determination of Fsh Quantity and Bioactivity During Sex} Differentiation and Oogenesis in European Sea Bass

\author{
Gregorio Molés, Ana Gómez, Manuel Carrillo, Ana Rocha, Constantinos \\ C. Mylonas, Silvia Zanuy
} Biology of Reproduction (DOI:10.1095/biolreprod.111.091868) 



\begin{abstract}
Follicle-stimulating hormone (FSH) is a glycoprotein hormone that plays a key role in the regulation of gonadal functions in vertebrates. The present study reports the monitoring of pituitary and plasma Fsh levels during sex differentiation and oogenesis in European sea bass (Dicentrarchus labrax) using a homologous immunoassay and an in vitro bioassay. Both assays were used complementarily for the first time in a fish species. High levels of Fsh bioactivity in plasma were found during the initial phases of sexual differentiation. Plasma and pituitary Fsh (quantity and bioactivity) levels and Biological to Immunological (B:I) ratios were higher in females than in males, suggesting sexual dimorphism in the synthesis and potency of Fsh. In females, the B:I ratios in adult were lower than during sex differentiation indicating that Fsh would be less biopotent in the adult stage. Plasma Fsh bioactivity levels increased during vitellogenesis pointing to that Fsh would be involved in the regulation of the mid phases of oogenesis, whereas luteinizing hormone (Lh) would be responsible for the final events.
\end{abstract}

Keywords: Gonadotropin, FSH receptor, biopotency, dot-blot immunoassay, hormone levels, Perciform fish 


\section{Introduction}

The gonadotropins (GTHs), follicle-stimulating hormone (FSH) and luteinizing hormone (LH), are heterodimeric glycoproteins synthesized and secreted by the pituitary gland. The GTHs are formed by the non-covalent association of a common alpha subunit (CGA) with distinct beta subunits (FSHB and LHB) that confer hormone specificity [1, 2]. Both GTHs are essential in the endocrine control of vertebrate reproduction, by regulating gonadal steroidogenesis and gametogenesis through the specific interactions with their respective receptor, LH receptor (LHR) and FSH receptor (FSHR). In most teleost orders, the functional duality between Fsh and Lh in critical moments of the reproductive life cycle, such as sex differentiation, puberty or gametogenesis has not yet been clarified adequately, despite the recognized importance of the two GTHs in reproduction. This is caused primarily by the lack of appropriate tools for measuring fish GTHs, especially assays for determination of Fsh levels.

Among teleosts, homologous immunoassays for Fsh have been developed only in three fish species with synchronous ovarian development, the chum salmon (Oncorhynchus keta) [3] coho salmon (Oncorhynchus kisutch) [4, 5] and rainbow trout (Oncorhynchus mykiss) [6, 7], and one with an asynchronous ovarian development, the tilapia (Oreochromis niloticus) [8]. In other fish species, such quantitative tools have been restricted to Lh, a fact that hampered studies on the functional duality of Fsh and Lh in fish. Results obtained so far indicate that in salmonids Fsh regulates the early phases of gametogenesis, such as vitellogenesis and spermatogenesis, whereas Lh is responsible for the late phases, such as oocyte maturation, ovulation and spermiation [9]. Nevertheless, in tilapia, the only non-salmonid species studied so far, a concomitant increase of Fsh and Lh levels was observed during the vitellogenic phase, suggesting that in this perciform species Lh may play a role not only during oocyte maturation, but also at vitellogenesis [8].

A few studies have also focused on the role of GTHs during sex differentiation. The endocrine control of sex differentiation involves a communication between the brain, pituitary and gonad through the production of GTHs and steroids [10]. The GTHs have been shown to play a critical role in sex differentiation both in gonochoristic and hermaphroditic fishes [11-13], but the underlying mechanisms behind these observations remain largely 
unknown. A variation in the chronological appearance of pituitary Fsh and Lh cells during sex differentiation has been reported in several teleost species $[12,14,15,16,17]$. Furthermore, sexually dimorphic expression of $f s h b$ was found in the hermaphrodite teleost honeycomb grouper (Epinephelus merra), suggesting that Fsh may trigger sex reversal in this species [11].

The European sea bass (Dicentrarchus labrax) is a perciform fish used in both applied and basic studies, due to its high commercial value and the large number of molecular and physiological tools available for the study of its reproductive process. This marine fish has a group-synchronous type of ovarian development [18], and the role of Fsh during sex differentiation and the reproductive cycle are still not well clarified. Studies performed in the last few years have allowed the elucidation of some physiological and biochemical aspects of Fsh actions in this species. For example, expression analysis of the genes coding for the GTH subunits [19] and the enzyme cytochrome P450 aromatase (Cyp19a1, previously known as P450aromA) [20] during sex differentiation suggested a role of Fsh during this period. Studies with European sea bass Fsh demonstrated a high specificity in the activation of its cognate receptor in a dose-dependent manner and its ability to stimulate the production of sex steroids by in vitro culture of gonads [21, 22]. However, while in females both GTHs were equally potent in stimulating $17 \beta$-estradiol (E2) secretion, in males Lh seemed to be more potent than Fsh in stimulating 11-ketotestosterone (11-KT) production. Analysis of seasonal expression of European sea bass GTH receptor genes ( $f$ shr and $l h r$ ) in sexually mature females revealed that the maximum $f s h r$ expression occurred before (late- and post-vitellogenesis) the maximum $\mathrm{lhr}$ expression (oocyte maturation and ovulation). A positive relationship was observed between ovarian levels of fshr mRNA, cyp19a1 mRNA and those of plasma E2, and Ihr mRNA and Lh plasma levels [23]. However, in order to clarify how Fsh modulates gonadal functions, knowledge about the kinetics of the levels of this hormone in the pituitary and plasma is imperative, but this information is still lacking for the European sea bass, as well as for most fish species.

Different types of assays have been developed for the measurement of FSH in various animals. These methods can be grouped in assays that determine a response of a biological system to stimulation with FSH (e.g. bioassays, both in vivo and in vitro) and assays that estimate high affinity binding to molecules which exhibit specific properties of molecular recognition (e.g. immunoassays). In contrast to the former, these latter assays are intended to 
measure the number of molecules or their mass. However, bioassays are an ideal means to determine the functional aspects of GTHs. Since the pituitary glicoproteins are highly heterogeneous in terms of carbohydrate composition, the bioactivity of the different isoforms present in the pituitary and blood may vary greatly and does not always match their immunoreactivity $[24,25]$. Since the early 1990 s a new generation of bioassays based on cell lines expressing the FSHR gene has emerged as a tool to measure serum FSH in mammalian species [26-30].

Based on the above information, the objective of the present study was to develop methods to measure both bioactivity and quantity of Fsh in this important European aquaculture and fish reproduction research species, and to generate new information on its role in the process of sex differentiation and control of the reproductive cycle of European sea bass.

\section{Materials and methods}

\subsection{Experimental animals and sample collection}

Two sibling populations of European sea bass, one of very small fish (predominantly males) and another of very large fish (predominantly females) were generated by four sequential size gradings during the period between 66 and 223 days post hatching (dph) [31]. At each grading the fish were split approximately in a 50:50 ratio into large and small populations. After the first grading, the large fish from the large population and the small fish from the small population were kept. Since the eventual very small and very large populations consisted of $70 \%$ males and $96 \%$ females, respectively, these populations in the present study were referred to as males and females. Samples were collected from both populations every 50 days from 150 to $300 \mathrm{dph}$ and 6 pituitaries and 10 plasma samples per sampling point were analyzed. The body weight and total length (mean $\pm \mathrm{SD})$ at $150 \mathrm{dph}$ were $6.6 \pm 0.24 \mathrm{~g}$ and $85.1 \pm 0.96 \mathrm{~mm}$ in males; $9.3 \pm 0.24 \mathrm{~g}$ and $96.3 \pm 0.76 \mathrm{~mm}$ in females. At $300 \mathrm{dph}$ males weighted $66.7 \pm 0.93 \mathrm{~g}$ and were $180.3 \pm 0.72 \mathrm{~mm}$ while females had $130.9 \pm 1.75 \mathrm{~g}$ and a total length of $218.8 \pm 0.75 \mathrm{~mm}$.

Sexually mature females maintained in Torre la Sal, Spain $\left(40^{\circ} \mathrm{NL}\right)$, were sampled monthly during their first reproductive period, which generally occurs during the third year of life. For each pituitary and blood collection, 5 fish were anesthetized and sacrificed in accordance with the Spanish 
legislation concerning the protection of animals used for experimentation or other scientific purposes. Blood was collected by caudal puncture with heparinized syringes and centrifuged $\left(3000 \mathrm{~g}\right.$ for $30 \mathrm{~min}$ at $\left.4{ }^{\circ} \mathrm{C}\right)$. The upper plasma layer was separated and stored at $-20^{\circ} \mathrm{C}$ until use. Pituitary glands were collected, immediately frozen in liquid nitrogen and stored at $-80^{\circ} \mathrm{C}$. For analysis, individual pituitaries were homogenized mechanically in TBS$\mathrm{T}$ (10 mM Tris-base, $150 \mathrm{mM} \mathrm{NaCl}$ and $0.05 \%$ Tween-20) using sterile syringes. The extract was centrifuged ( $3000 \mathrm{~g}$ for $15 \mathrm{~min}$ at $4^{\circ} \mathrm{C}$ ) to eliminate debris and stored at $-80^{\circ} \mathrm{C}$ until assayed. The stages of ovarian development were classified by light microscopy as in Rocha et al. [23], following previously established criteria [32]: previtellogenesis (prevtg), early vitellogenesis (evtg), late-vitellogenesis and post-vitellogenesis (lvtg-pvtg), maturation and ovulation (mat-ovul), and atresia (atre).

\subsection{Biological activity determinations for European sea bass Fsh}

In order to determine bioactive Fsh an in vitro bioassay was developed. The biological activity of Fsh in pituitary and plasma samples was analyzed using a human embryonic kidney (HEK) 293 cell line stably expressing the European sea bass Fsh receptor (sbsFshr) and the firefly luciferase reporter gene under the control of a promoter with cAMP Responsive Elements (CRE) binding sites (pCRE-LUC) [33]. The HEK 293 cells were grown at $37^{\circ} \mathrm{C}$ in DMEM medium (Invitrogen) supplemented with $10 \%$ foetal bovine serum (FBS), $100 \mathrm{U} \mathrm{ml}^{-1}$ penicillin and $100 \mu \mathrm{g} \mathrm{ml}^{-1}$ streptomycin (Invitrogen) in a humidified incubator supplied with $5 \% \mathrm{CO}_{2}$. Receptor activation by FSH was indirectly measured by recording changes in luciferase activity, promoted by a rise of cAMP. Cells from the sbsFshr/pCRE-LUC HEK293 stable clone were seeded in 96 well cell culture plates (Corning) at a density of $4.5 \times 10^{5}$ cells well $^{-1}$ in $300 \mu \mathrm{l}$ of growth medium. After $16-20 \mathrm{~h}$, medium was removed and cells were incubated with $100 \mu \mathrm{l}$ of FSH standards or sample preparations per well (1/25 plasma; $1 / 2000-12000$ pituitary extract) in OPTIMEM or Advanced-DMEM media (Invitrogen) supplemented with $1 \%$ glutamine, $100 \mathrm{U} \mathrm{ml}^{-1}$ penicillin and $100 \mu \mathrm{g} \mathrm{ml}^{-1}$ streptomycin. After $6 \mathrm{~h}$ incubation, luciferase activity was directly quantified on the plates using the Steady-Glo Luciferase Assay System (Promega) and the ULTRA Evolution (TECAN) detection platform. All samples were measured in triplicate and the light emitted expressed as relative lights units (RLU). Known quantities 
of recombinant European sea bass Fsh dimer produced in Chinese Hamster Ovary cells (CHO-scFsh) or insect cells (Sf9-Fsh) [22] were used as standard curve. After logarithmic transformation, the standard curve was linearized and a concentration could be extrapolated for each sample analyzed.

\subsection{Plasma Lh and Fsh extraction by lectin}

Extraction of plasma Fsh and Lh was performed by affinity chromatography with Concanavalin A (Con A) Sepharose 4B (GE Healthcare). Briefly, a column with $1 \mathrm{ml}$ of Con A Sheparose was equilibrated with $20 \mathrm{mM}$ Tris buffer containing $0.5 \mathrm{M} \mathrm{NaCl}, 1 \mathrm{mM} \mathrm{MnCl}, 1 \mathrm{mM} \mathrm{CaCl}$ and $1 \mathrm{mM} \mathrm{MgCl}$, $\mathrm{pH}$ 7.4, and loaded with a pool of plasma samples (6.84 mg protein). The flow-through plasma, consisting of plasma free of Lh and Fsh, was stored at $-20^{\circ} \mathrm{C}$ until use. Con A-bound GTHs were eluted with $10 \mathrm{mM}$ methyl $\alpha$-Dglucopyranoside and $300 \mathrm{mM}$ methyl $\alpha$-D-mannopyranoside.

\subsection{Production and purification of recombinant European sea bass Fshb}

To generate specific polyclonal antibodies, recombinant Fshb was produced using the Bac-to-Bac Baculovirus Expression System as described previously by Molés et al. [22]. Briefly, a cDNA fragment containing the open reading frame of European sea bass $f s h b$ and a C-terminal 6xHis tag were obtained by PCR using specific primers. The cDNA was directionally cloned into donor plasmid pFastBac1 and used to generate recombinant baculovirus by transposition. The baculovirus-Fshb was used to infect insect cells derived from the fall armyworm Spodoptera frugiperda (Sf9). The Sf9 cells were grown at $28^{\circ} \mathrm{C}$ in Sf-900 II SFM medium (Invitrogen), containing 100 $\mathrm{U} \mathrm{ml}^{-1}$ penicillin and $100 \mu \mathrm{g} \mathrm{ml}^{-1}$ streptomycin (Invitrogen). Monolayer cultures of Sf9 cells were grown to $80-85 \%$ of confluence (roughly $12 \times 10^{6}$ cells) and later infected at a multiplicity of infection (MOI) of $3 \mathrm{pfu} \mathrm{ml}^{-1}$ during 4-5 days. Cells and medium were then harvested by centrifugation (110g, 10 min) and stored at $-80^{\circ} \mathrm{C}$ until used. The infected cells were resuspended in lysis buffer (50 mM Tris- $\mathrm{HCl}$ pH 8.0, $100 \mathrm{mM} \mathrm{KCl,} \mathrm{1 \%} \mathrm{Nonidet} \mathrm{P-40,} 1 \mathrm{mM}$ PMSF and $1 \mu \mathrm{g} \mathrm{ml}^{-1}$ Aprotinin) and their cell membrane disrupted by brief periods of sonication on ice using a cell disrupter (Vibracell; Sonics \& Materials, Inc.). Supernatants containing soluble proteins were recovered after removal of cell debris by centrifugation at $35000 \mathrm{~g}$ for $30 \mathrm{~min}$ at $4^{\circ} \mathrm{C}$. 
Recombinant Fshb from supernatants of Sf9 cell lysates was purified by immobilized metal affinity chromatography (IMAC $\mathrm{Ni}^{2+}$ ) using His GraviTrap prepacked columns (GE Healthcare) according to manufacturer instructions. Briefly, the $\mathrm{pH}$ of the supernatant was adjusted to 7-8 with diluted acetic acid and the prepacked columns were equilibrated with PBS (20 mM sodium phosphate, $500 \mathrm{mM} \mathrm{NaCl}, \mathrm{pH}$ 7.4) containing $20 \mathrm{mM}$ imidazole. After loading the supernatants, three washes with PBS $(20 \mathrm{mM}, 70 \mathrm{mM}$ and $100 \mathrm{mM}$ Imidazole) were performed. Finally the bound Fshb was eluted with PBS containing $500 \mathrm{mM}$ Imidazole. The purity of fractions obtained was analyzed by sodium dodecyl sulfate-polyacrylamide gel electrophoresis (SDS-PAGE) and Western-blot.

A second purification step was performed consisting of a protein extraction from the SDS-PAGE gel by passive elution. Proteins obtained by the IMAC purification were separated by a SDS-PAGE (11\%) under reducing conditions (5\% 2-mercaptoethanol). The gel was stained with a negative and reversible protein stain for polyacrylamide gels (E-Zinc Stain; PIERCE) and the band corresponding to Fshb was excised. Individual slices were placed in microcentrifuge tubes and protein was extracted from the gel by passive elution in $0.1-0.2 \mathrm{ml} \mathrm{band}^{-1}$ of buffer ( $50 \mathrm{mM}$ Tris- $\mathrm{HCl}, 150 \mathrm{mM} \mathrm{NaCl}$, and 0.1 mM EDTA; pH 7.5) following a method adapted from the PIERCE technical resource (TR0051.0). The tubes were incubated overnight at $4{ }^{\circ} \mathrm{C}$ followed by $2 \mathrm{~h}$ incubation at $25^{\circ} \mathrm{C}$ in rotary shaker (300 rpm). Finally, a centrifugation at $10,000 \mathrm{~g}$ for 10 minutes at $4^{\circ} \mathrm{C}$ was performed and the supernatants stored at $-80^{\circ} \mathrm{C}$. Protein purity was confirmed by SDS-PAGE (15\%) and staining with Coomassie brilliant blue.

\subsection{Western blot analysis}

The proteins separated by SDS-PAGE were transferred to PVDF membranes (Immobilon P, Millipore). The membranes were blocked overnight with $5 \%$ skimmed milk at $4{ }^{\circ} \mathrm{C}$, incubated for $90 \mathrm{~min}$ at room temperature with anti-6xHis (1:6000) (mAb/HRP Conjugate; Clontech) or anti-mummichog Fshb (anti-mFshb) (1:3500) already validated for European sea bass Fshb [21], washed and incubated with 1:2000 goat anti-rabbit IgG horseradish peroxidase conjugate (GAR-HRP, Bio-Rad), for $60 \mathrm{~min}$ at room temperature. The immunodetection was performed by chemiluminescence (Western Blotting Luminol Reagent, Santa Cruz Biotechnology, Inc.) using the 
Versadoc image system (Bio-Rad).

\subsection{European sea bass Fshb antibody production}

Polyclonal antibodies against the purified recombinant Fshb were produced by a commercial company (Agrisera, Sweden). Two rabbits were immunized with $60 \mu \mathrm{g}$ of Fshb in Freund's complete adjuvant by subcutaneous injection. Four subsequent immunizations were carried out with $25 \mu \mathrm{g}$ of antigen in Freund's incomplete adjuvant at 3-week intervals. Rabbits were bled 2 weeks before immunizations (pre-immune serum) and 2 weeks after immunizations III, IV and V, in order to perform the corresponding titration test. Final bleeding was done at 2 weeks after the fifth immunization.

\subsection{Immunological determination of European sea bass Fsh}

A dot-blot immunoassay was developed for immunological determination of Fsh. The sample preparations (1/50-250 pituitary extracts) were previously denatured $\left(5 \% 2\right.$-mercaptoethanol, 4 min $95^{\circ} \mathrm{C}$ ) and immobilized on a PVDF membrane (Immobilon P, Millipore) using a Bio-Dot microfiltration apparatus (Bio-Rad). The membrane was blocked overnight with $5 \%$ skimmed milk in TBS-T at $4^{\circ} \mathrm{C}$, incubated with the anti-European sea bass Fshb produced (anti-sbsFshb) (1/2000) for $90 \mathrm{~min}$ at room temperature, washed and incubated with goat anti-rabbit IgG (1/1000) horseradish peroxidase conjugate (GAR-HRP; Bio-Rad) for $60 \mathrm{~min}$ at room temperature. The immunodetection was performed by chemiluminescence (Western Blotting Luminol Reagent; Santa Cruz Biotechnology, Inc.) using the Versadoc image system (Bio-Rad). All samples were measured in duplicate. Immunoreactivity signal (Intensity $\left(\mathrm{mm}^{2}\right)^{-1}$ ) was calculated for each dot and compared to those obtained from serial dilutions of standard using the image analysis software Quantity One v 4.4 (Bio-Rad). Known quantities of purified native European sea bass Fsh [21] were used as standard curve. After logarithmic transformation, the standard curve was linearized and a concentration could be extrapolated for each sample analyzed.

\subsection{Pituitary European sea bass Lh measurements}

Levels of Lh in pituitary were measured by homologous competitive en- 
zyme-linked immunosorbent assay (ELISA) according to Mateos et al. [34]. The sensitivity of the assay was $0.65 \mathrm{ng} \mathrm{ml}^{-1}(\mathrm{Bi} / \mathrm{Bo} 80 \%)$ and intra- and interassay coefficients of variation were $11.7 \%$ and $11 \%$, respectively.

\subsection{Immunohistochemistry}

In order to locate the gonadotrope cells in the pituitary an immunohistochemistry was performed. Two-year old sexually mature male and three year old mature female European sea bass were anesthetized in $0.1 \%$ (2)-phenoxyethanol (Merck) and then transcardially perfused with a fixative solution (4\% paraformaldehyde in $0.1 \mathrm{M}$ phosphate buffer $\mathrm{pH}$ 7.4). The brains were carefully extracted with the pituitary attached and postfixed overnight at $4^{\circ} \mathrm{C}$, dehydrated and embedded in paraffin. Before immunostaining, $6 \mu \mathrm{m}$ transversal sections were deparaffinized and washed in TBS-T (0.1\% Triton X-100) for $10 \mathrm{~min}$. Endogenous peroxidase activity was blocked with $1 \% \mathrm{H}_{2} \mathrm{O}_{2}$ in TBS-T for $30 \mathrm{~min}$. For epitope unmasking, samples were warmed up at $90-95^{\circ} \mathrm{C}$ in $0.01 \mathrm{M}$ Sodium Citrate buffer ( $\mathrm{pH}$ 6) for $10 \mathrm{~min}$ and left to temper at room temperature for $15 \mathrm{~min}$. Sections were saturated with 3\% goat serum (Sigma-Aldrich) in TBS-T for $45 \mathrm{~min}$ in order to reduce non-specific reactions. They were then incubated with rabbit anti-sbsFshb $(1 / 500)$ or anti-European sea bass Lhb (anti-sbsLhb) (1/1000) [34] overnight at room temperature. Sections were rinsed three times with TBS-T for 10 min and were incubated with GAR-HRP (1/200) for $100 \mathrm{~min}$. Finally, sections were rinsed with TBS-T (2x10 min) and 0.05 M Tris- $\mathrm{HCl}(\mathrm{pH} 7.6)(1 \times 10$ $\mathrm{min})$ and peroxidase activity was visualized by treatment with $0.025 \%(\mathrm{w} / \mathrm{v})$ 3,3'-diaminobenzidine tetrahydrochloride and $0.01 \%(\mathrm{v} / \mathrm{v}) \mathrm{H}_{2} \mathrm{O}_{2}$ in $0.05 \mathrm{M}$ Tris- $\mathrm{HCl}$ buffer ( $\mathrm{pH}$ 7.6) for 5-15 min. The sections were then rinsed, counterstained with hematoxylin (25\%), dehydrated in ethanol, cleared in xylene, and cover slipped with DPX mounting medium (Panreac).

The immunostained sections were observed under a light microscope (Nikon Elipse) and were photographed digitally. The specificity of the immunoreaction was confirmed by incubating the sections with pre-immune rabbit serum instead of the specific anti-sbsFshb (data not shown).

\subsection{Data representation and statistical analysis}

Due to the different concentrations obtained according to the assay used, 
the Fsh levels have been expressed as relative values for a better understanding and comparison of the results. The $200 \mathrm{dph}$ males exhibiting the first histological signs of gonadal differentiation [31] were chosen as the reference group to study the Fsh profile during the sex differentiation period. To study the Fsh profile of females during oogenesis the samples were grouped according to the ovarian stage of development (see section 2.1) and early vitellogenic females were chosen as the reference group. The Fsh levels of these reference groups were set as 1 . Statistical significance of the differences between group means of hormone levels or receptor activation (luciferase activity) was determined by one-way Analysis of Variance (ANOVA) followed by Holm-Sidak method using SigmaStat 3.5 (Systat Software Inc.). When the test of equal variance failed, ANOVA on Ranks (Kruskal-Wallis) was performed followed by all pair-wise multiple comparison procedures (Dunn's method). The correlation coefficents (R) between the two assays were calculated using the Pearson product moment test. Data are presented as mean \pm SEM.

After conversion of the results to relative levels, the pituitary Fsh biological to immunological (B:I) ratio was calculated by dividing the pituitary values obtained from the bioassay by those from the immunoassay.

\section{Results}

\subsection{Development and validation of the European sea bass Fsh bioassay}

Previous studies have shown that the sbsFshr/pCRE-LUC HEK293 stable clone expressed the luciferase gene in a dose dependent manner when stimulated with European sea bass Fsh [21, 22]. Since stimulation of luciferase activity declines with time, the luminescent signal was monitored over time after treatment with Fsh. Incubation of sbsFshr/pCRE-LUC HEK293 cells with a single dose of recombinant CHO-scFsh for 3, 6, 9, 15, 20 or $24 \mathrm{~h}$ showed maximum stimulation between 6 and $9 \mathrm{~h}$ (data not shown). A $6 \mathrm{~h}$ incubation time was used for all further studies.

The Fsh specificity of the sbsFshr cell line was examined previously by the addition of recombinant European sea bass Lh and other heterologous gonadotropins [22]. Dilutions of recombinant Fshs (CHO-scFsh and Sf9-Fsh), pituitary extracts and plasma samples were tested in the luciferase assay system. All of them stimulated the sbsFshr in a dose-dependent manner, 
similar to native Fsh standard curve (Fig. 1A). To detect potential nonspecific plasma effects in the rise of intracellular cAMP, receptor activation with Con A-treated plasma was analyzed and no activation was detected (Fig. 1B).

The sensitivity of the bioassay, defined as the lowest concentration of Fsh able to stimulate a luciferase activity higher than the mean plus 2 times the standard deviation of the zero concentration of Fsh (basal), was $0.104 \mathrm{ng}$
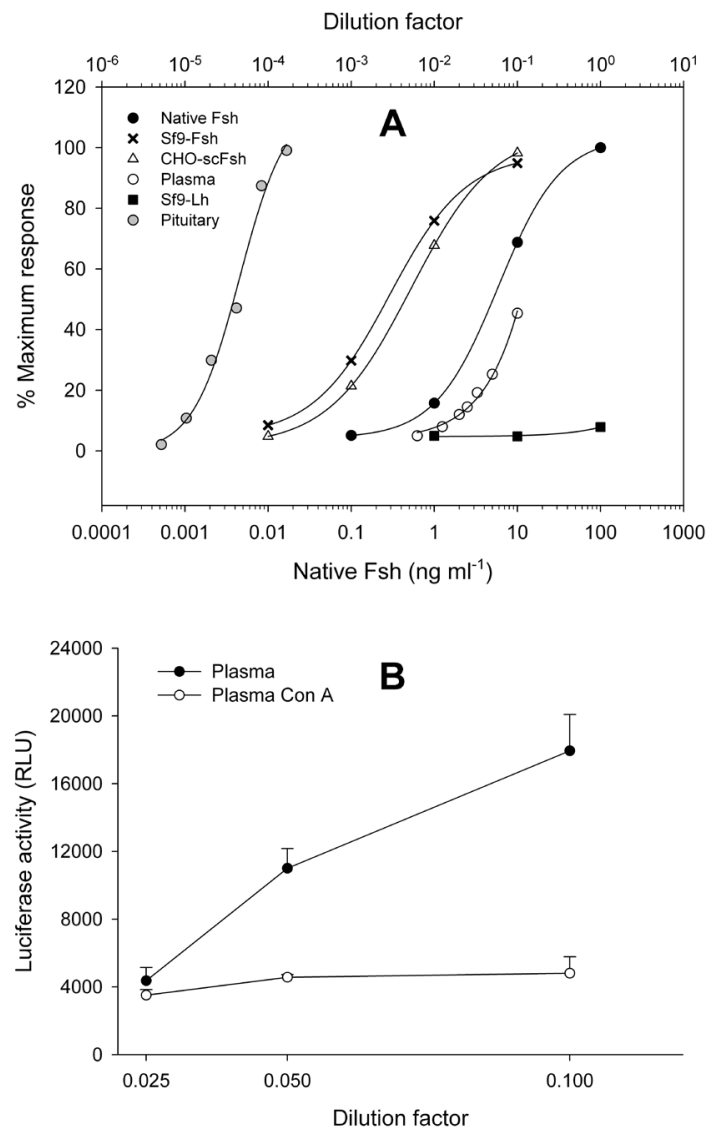

Figure 1. Development of European sea bass Fsh bioassay. A) Dose-response curves. SbsFshr/ pCRE-LUC HEK293 cells were incubated with standard curve of purified native Fsh and serial dilutions of plasma samples, pituitary extract and recombinant European sea bass Fshs (Sf9Fsh and CHO-scFsh) and Lh (Sf9-Lh). Data points represent the mean of three independent determinations. B) Effect of GTHs-free plasma in luciferase stimulation. SbsFshr/pCRE-LUC HEK293 cells were incubated with GTHs plasma extracted and non-extracted with lectin Con A. Samples were measured in triplicate (Mean \pm SEM) and the light emitted expressed as relative lights units (RLU). 
$\mathrm{ml}^{-1}$. The intra-assay coefficient of variation (CV), calculated by measuring replicates of the same sample $(n=14)$ within the assay, was estimated at $9.3 \%$. The inter-assay $\mathrm{CV}$, calculated by measuring replicates of same sample in different assays $(\mathrm{n}=10)$, was $10.9 \%$.

\subsection{Development and validation of European sea bass Fsh dot-blot immu- noassay}

In order to generate antibodies against European sea bass Fshb and develop a specific immunoassay, recombinant Fshb was produced using the baculovirus expression system. In this system, recombinant Fshb remained inside the infected cells instead of being secreted [22]. Therefore, recombinant Fshb was purified from cell lysates by affinity chromatography (IMAC $\mathrm{Ni}^{2+}$ ). Analysis by SDS-PAGE and western blot with anti-6xHis (data not shown) and anti-mFshb confirmed the identity and abundance of Fshb in the obtained fractions (Fig. 2A and 2B). However, the Coomassie blue stain showed the presence of high molecular weight proteins in addition to Fshb (Fig. 2A) and, thus, another step of purification was necessary to obtain a satisfactory degree of purity. Due to its excellent ability to resolve individual components of protein mixtures, SDS-PAGE was used as an active step in the purification process. Finally, after protein extraction by passive elution, a high degree of antigen purity was achieved (Fig. 2C).

Polyclonal antibodies against European sea bass Fshb were obtained by rabbit immunizations using this purified protein. The antibodies reacted

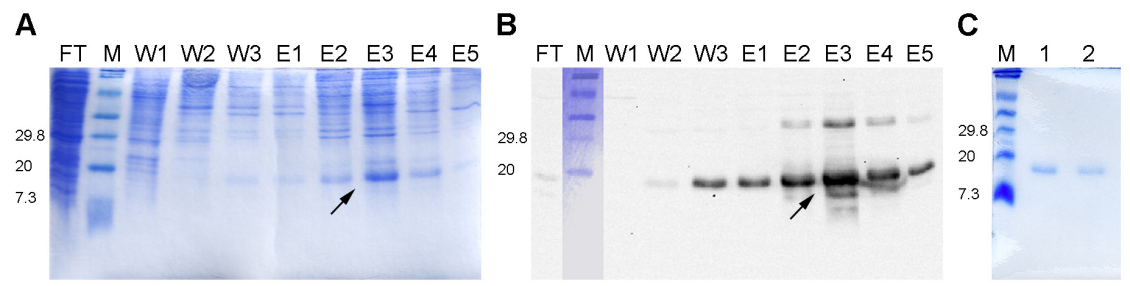

Figure 2. SDS-PAGE and western blot analysis of purified recombinant Fshb. A) Proteins stained with Coomassie blue and B) western blot with anti-mFshb, after affinity chromatography $\left(\mathrm{IMAC} \mathrm{Ni}{ }^{2+}\right)$. FT: Flow-through $\left(10 \mu 1\right.$ lane $\left.^{-1}\right)$; W1-W3: wash with PBS containing $20 \mathrm{mM}$, $70 \mathrm{mM}$ and $100 \mathrm{mM}$ Imidazole, respectively $\left(15 \mu \mathrm{llane} \mathrm{e}^{-1}\right)$; E1-E4: Elution of Fshb (arrows) with

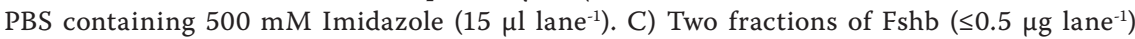
stained with Comassie blue after protein extraction from SDS-PAGE by passive elution. M: Bio-Rad prestained Broad Range molecular weight marker. 
strongly and specifically with Fshb under reducing conditions, however, a very weak reaction was obtained under non-reducing conditions (Fig. 3A and $3 \mathrm{~B}$ ). Therefore, a dot-blot immunoassay was developed for Fsh determination in denatured samples. Validation of the assay was performed only for pituitary samples because the plasma Fsh concentrations were below or near the limit of detection. The sensitivity of the immunoassay, defined as the lowest dose of Fsh able to increase a dot density higher than the mean plus 2 times the standard deviation of zero dose of Fsh (basal), was of 162.8 $\mathrm{ng} \mathrm{ml} \mathrm{l}^{-1}$. Dose-response curves of pituitary extracts and recombinant Fsh (Sf9-Fsh) were similar to the standard curve of native purified Fsh. No crossreactivity was detected with serial dilutions of recombinant Lh (Fig. 4). The intra-assay $\mathrm{CV}$, calculated by measuring replicates of the same sample within the assay $(n=10)$, was estimated at $9.8 \%$. The inter-assay $C V$, calculated by measuring replicates of same sample in different assays $(n=8)$, was $11.5 \%$.

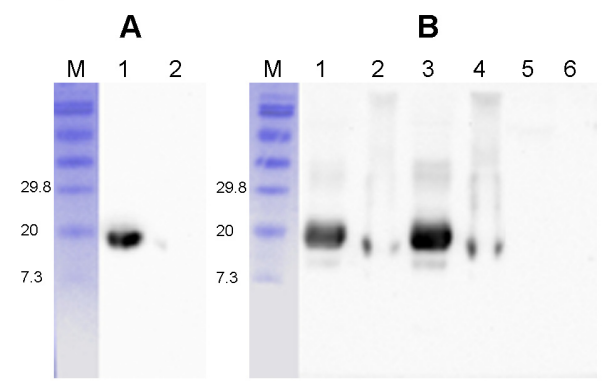

Figure 3. Analysis of polyclonal antibodies for European sea bass Fshb by Western blot. A) Test of the antiserum after the third immunization (1/4000). Lanes 1-2: $300 \mathrm{ng}$ of purified native Fsh under reduction and native conditions, respectively. B) Test of the antiserum after final bleeding (1/2000). Lanes 1 to 4: $760 \mathrm{ng}(1-2)$ and $1520 \mathrm{ng}$ (3-4) of pituitary extract under reducing $(1,3)$ and non-reducing $(2,4)$ conditions. Lanes 5-6: 1000 and 2000 ng of European sea bass Lh under reducing conditions. M: Bio-Rad prestained Broad Range molecular weight marker.

\subsection{Determination of Fsh levels during sex differentiation and the reproduc- tive cycle}

The assays developed in this study were used to analyse the profiles of Fsh in pituitary extracts and plasma samples from male and female sibling populations during sex differentiation, specifically from $150 \mathrm{dph}$ to 300 $\mathrm{dph}$. The quantity and bioactivity profiles of pituitary Fsh were very similar, 


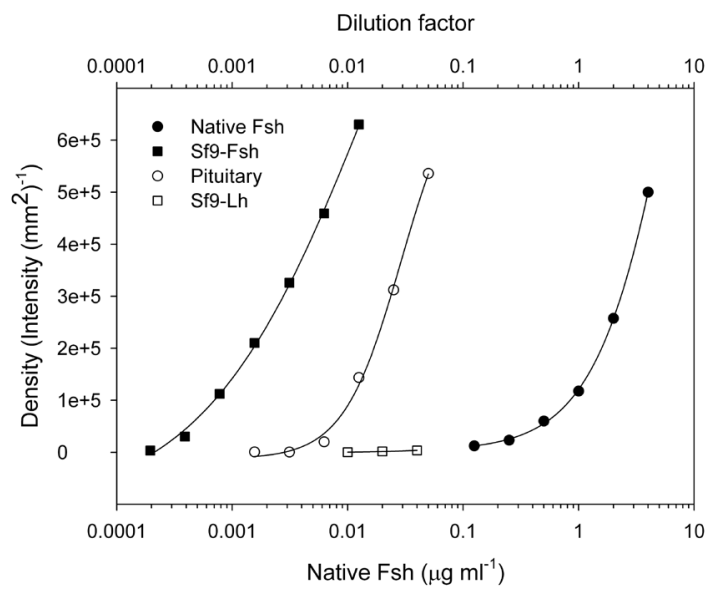

Figure 4. Dose-response curves for the European sea bass Fsh immunoassay. Standard curve of purified native Fsh, serial dilutions of pituitary extract and recombinant European sea bass GTHs produced in Sf9 insect cells (Sf9-Fsh and Sf9-Lh) were immobilized on a membrane and incubated with the anti-sbsFshb antibody. The 1/25 (0.04) dilution of Sf9-Lh corresponds with a concentration of $5.6 \mu \mathrm{g} \mathrm{ml}^{-1}$. Data points represent the mean of two independent determinations.

showing high coefficient of correlation both in males and females (Fig. 5A), nevertheless the absolute concentrations calculated by immunoassay were always higher than by bioassay. Relative values, respect to males at $200 \mathrm{dph}$, were used to plot the profiles of pituitary and plasma Fsh along this period. At $200 \mathrm{dph}$, the mean content of pituitary Fsh in males, measured by immunoassay, was $6.04 \mu \mathrm{g}$ whereas the bioactivity was equal to $0.87 \mu \mathrm{g}$ of standard. At this sampling point, the plasma Fsh bioactivity was equal to $216 \mathrm{ng}$ $\mathrm{ml}^{-1}$ of standard. Relative levels showed that the bioactivity increased much more than the quantity respect to reference group, e.g. while the bioactivity increased $\sim 16$-fold, the amount of Fsh increased only $~ 6$-fold in females at 300 dph (Fig. 5B). At 150 dph, pituitary Fsh levels were very low in both sexes and increased significantly beginning $200-250 \mathrm{dph}$ (Fig. 5B). During the period studied, the Fsh levels tended to be higher in females than in males, regardless of the assay used. Moreover, the B:I ratio was higher in females than males (Table 1). The profile of plasma Fsh bioactivity was completely opposite to those of pituitary and in both sexes Fsh levels were higher at $150 \mathrm{dph}$ than at $300 \mathrm{dph}$ (Fig. 5C). As observed in the pituitary, there was a tendency for plasma Fsh levels to be higher in females than males. 
Figure 5. Profiles of Fsh in European sea bass males $(M)$ and females (F) during sex differentiation. A) Correlation between pituitary Fsh values as determined by bio- and immunoassay. B) Pituitary Fsh quantity and bioactivity levels. C) Plasma Fsh bioactivity levels. Data (mean \pm SEM of 6-10 fish) are expressed as a proportion of the mean FSH values in males at $200 \mathrm{dph}$ that was set as 1(Pituitary: Bioassay $=0,87 \mu \mathrm{g} /$ pituitary, Immunoassay $=6.04 \mu \mathrm{g} /$ pituitary; Plasma: Bioassay $=216 \mathrm{ng} \mathrm{ml}^{-1}$ ). Different letters indicate significant differences over time for female or male populations (capital letters for immunoassay and lowercase letters for bioassay). Asterisks (bioassay) and plus (immunoassay) indicate significant differences between the two populations at equivalent sampling points. Note: Statistics at 200 dph in immunoassay is $A B$ in males and $\mathrm{A}$ in females.
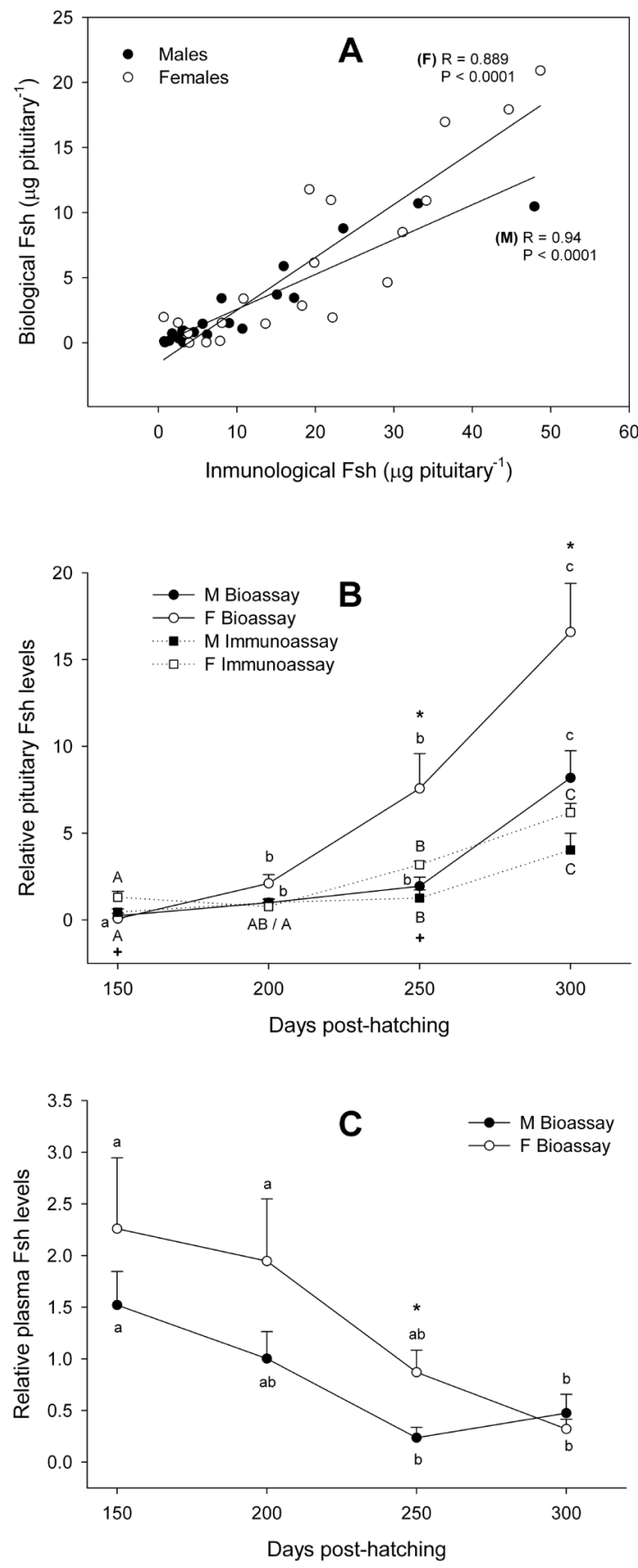
Similar to the study during sex differentiation, a high coefficient of correlation was obtained in the Fsh determinations of the quantity and bioactivity during the reproductive cycle of adult females (Fig. 6A). As above, the absolute concentrations calculated by the immunoassay were always higher than bioassay, and relative levels respect to early vitellogenic females were used to plot the Fsh profiles. In this stage (evtg), the mean content of pituitary Fsh, measured by immunoassay, was $71.01 \mu \mathrm{g}$ whereas the bioactivity was equal to $12.14 \mu \mathrm{g}$ of standard. The plasma Fsh bioactivity was equal to $4.03 \mathrm{ng} \mathrm{ml}^{-1}$
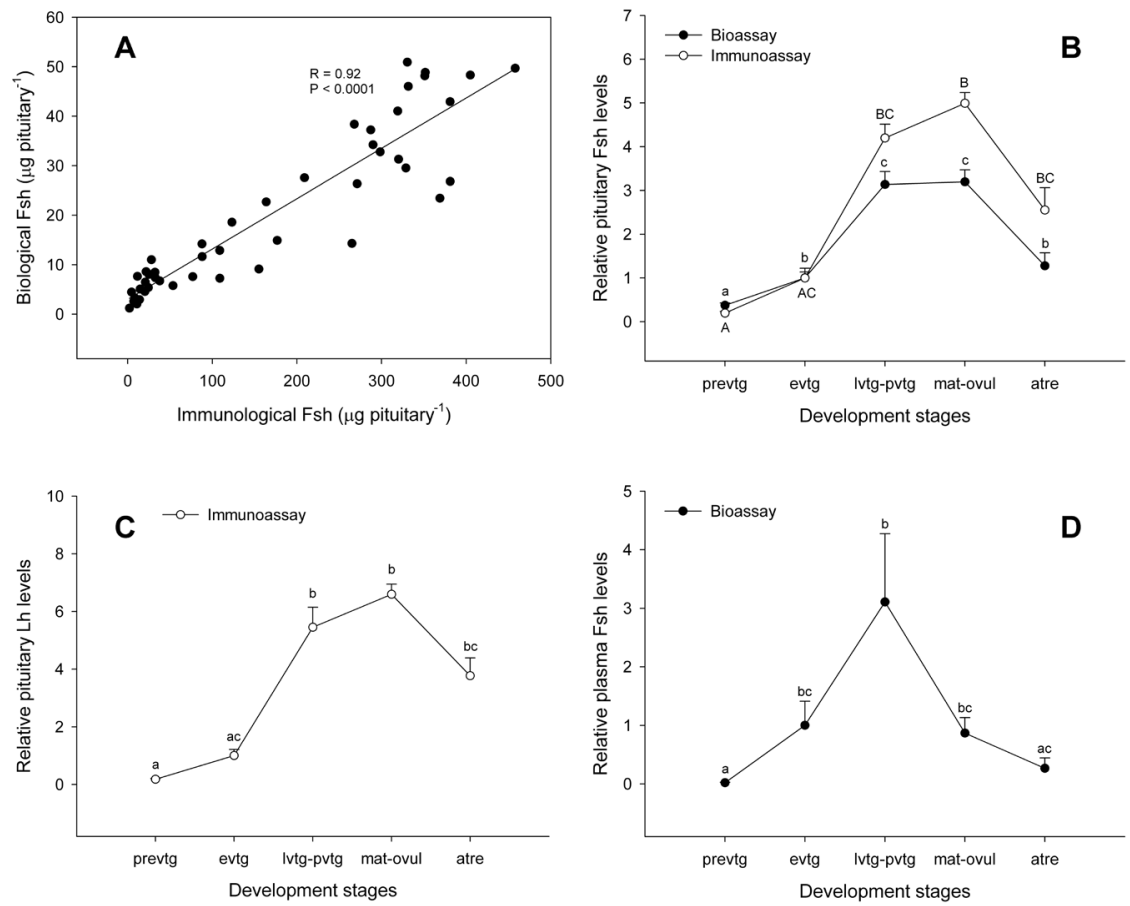

Figure 6. Annual profile of Fsh in adult female Europea sea bass during the first reproductive period. A) Correlation of pituitary Fsh values as determined by bio- and immunoassay. B) Pituitary Fsh quantity and bioactivity levels. C) Pituitary Lh quantity levels. D) Plasma Fsh bioactivity levels. Values were classified according to the stage of gonadal development as determined by histology. Previtellogenesis (prevtg), early vitellogenesis (evtg), late- and postvitellogenesis (lvtg-pvtg), maturation-ovulation (mat-ovul), and atresia (atre). Data (mean \pm SEM of 7-14 fish) are expressed as a proportion of the mean Fsh value of females in the early vitellogenesis stage that was set as 1 (Pituitary: Bioassay $=12.14 \mu \mathrm{g} /$ pituitary, Immunoassay= $71.01 \mu \mathrm{g} /$ pituitary; Plasma: Bioassay $\left.=4.03 \mathrm{ng} \mathrm{ml}^{-1}\right)$. Different letters indicate significant differences between developmental stages (capital letters for immunoassay and lowercase letters for bioassay). 
Table 1. Biological to Immunological (B:I) ratio in pituitary samples.

\begin{tabular}{lcccc|ccccc}
\hline & \multicolumn{3}{c|}{ Sex differentiation (dph) } & \multicolumn{5}{c}{ Reproductive cycle (stage) } \\
& $\mathbf{1 5 0}$ & $\mathbf{2 0 0}$ & $\mathbf{2 5 0}$ & $\mathbf{3 0 0}$ & prevtg & evtg & lvtg-pvtg & mat-ovul & atre \\
\hline Males & 0.54 & 1 & 1.55 & 2.03 & & & & & \\
Females & 0.06 & 2.74 & 2.38 & 2.68 & 1.93 & 1 & 0.75 & 0.64 & 0.50 \\
\hline
\end{tabular}

of standard. The quantity and bioactivity relative levels of pituitary Fsh in the pituitary increased during early vitellogenesis, peaked in late- and postvitellogenesis until maturation-ovulation, and finally in the atresia stage the levels tended to decline (Fig 6B). When the Fsh B:I ratio was calculated, this decreased throughout the cycle (Table 1). Concurrently, pituitary Lh levels had an identical profile to that of Fsh (Fig. 6C). In the plasma, the trend was that Fsh bioactivity levels increased during early vitellogenesis, peaked in late-vitellogenesis and post-vitellogenesis and decreased in maturationovulation stage (Fig 6D).

\subsection{Immunohistochemistry}

The antibodies against European sea bass Fshb or Lhb were used to differentially stain the pituitary gonadotropin producing cells of sexually mature male. Two different GTH cell populations expressing Fsh and Lh were observed (Fig. 7). The Fsh cells were distributed throughout the whole proximal pars distalis (PPD), isolated or arranged in small groups (Fig. 7A). Conversely, Lh formed strands or compact groups (Fig. 7B) distributed mostly in the ventral part of the PPD and surrounding the pars intermedia (PI) and were more numerous than Fsh cells. The same results were observed in a pituitary of a sexually mature female (data not shown).

\section{Discussion}

The present study reports, for the first time in a fish with group-synchronous ovarian development, the monitoring of the Fsh levels during critical moments of the reproductive life cycle using a newly developed bioassay and immunoassay. The immunological determinations of Fsh, based on antigen-antibody reaction, do not necessarily reflect the biological signal 


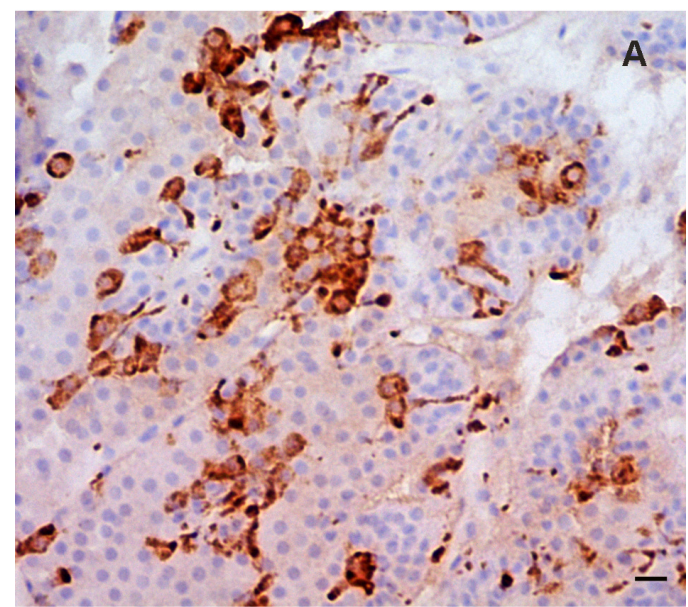

Figure 7. Two adjacent sections of a male European sea bass pituitary (proximal pars distalis) immunostained with anti-sbsFshb (A) and anti-sbsLhb (B). Bar $=10 \mu \mathrm{m}$.

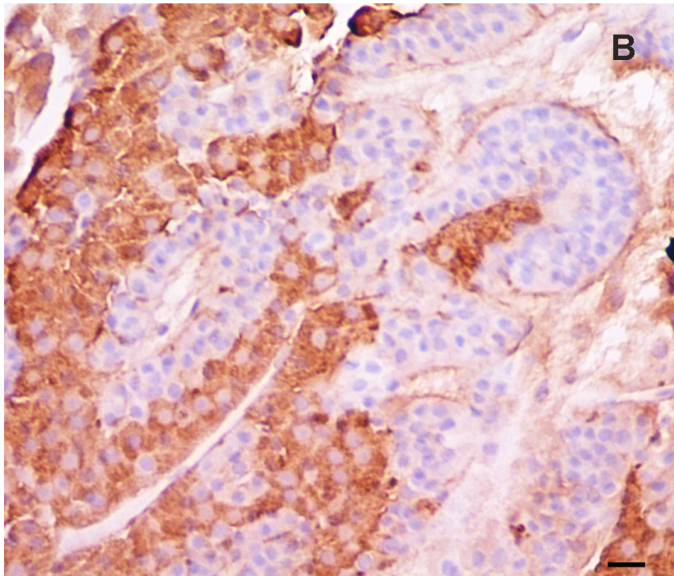

perceived by its cognate receptor [24]. Consequently, an in vitro bioassay for Fsh constitutes an ideal approach to determine functional aspects of this GTH. The bioassay developed here, using co-transfection of sbsFshr cDNA and a luciferase reporter gene in HEK 293 cells, exhibited dose-dependent receptor activation and was able to measure the bioactivity of European sea bass Fsh with a high degree of sensitivity and specificity. In fish, receptor transactivation systems have been used transiently transfected or as stable lines to investigate functional specificity of the receptor/hormone interactions using recombinant or native fish GTHs [9]. However, our homologous Fsh bioassay is the first one developed and validated in fish to measure Fsh bioactivity in pituitary and plasma samples. The bioassay showed optimal 
characteristics of precision, specificity and sensitivity, in concordance with those reported for other FSH bioassays in mammals [35].

Traditionally, the immunoassays developed to determine GTH levels in fish have been radioimmunoassays (RIA) or ELISA based on native GTHs subunits purified from fish pituitaries and their specific antibodies. Native Fsh purification is a highly demanding process as regards time, cost and substantial amount of pituitary glands required that often limits the production of specific antibodies [9]. In the present study, recombinant Fshb was produced using a baculovirus expression system. The production yield was high, but Fshb was undetectable in the culture medium, since most of the recombinant subunit was found in the cell lysate. The recombinant Fshb was isolated after two-step purification from cell lysates and used to produce polyclonal antibodies, which exhibited a strong reaction under reducing conditions, but a very weak reaction under native conditions. There is no clear explanation for this observation, but we could hypothesize that denaturation of the antigen during the purification process led to a different conformation from the native subunit that could have been crucial in the generation of antibodies that recognize mainly internal epitopes of the subunit. This explanation could account for the observed differences in reactivity under reducing versus native conditions. Despite this, a specific dot-blot immunoassay able to measure European sea bass Fsh in pituitary was developed. This assay did not show cross-reactivity with European sea bass Lh and showed a low intra- and inter-assays CVs, comparable to those reported for other fish Fsh immunoassays [3, 6, 8].

Studies in mammals have shown a relative abundance of intra-pituitary and circulating isoforms of GTHs that differ from each other not only in their carbohydrate composition, but also in their ability to remain in the blood stream and their biopotency, provoking a range of biological responses in vitro and in vivo [25]. Also, it is known that in experimental animals as well as in humans a close relationship exists between the presence of a particular isoform pattern in the pituitary and in circulation, and the functional state of the gonad $[25,27,36]$. Based on the assumption that immunoreactivity is a measure of the quantity of Fsh and that bioactivity provides information relative to the ability to elicit a biological response, the B:I ratio should provide an assessment of the average quality of individual Fsh molecules in a biological sample at a given time. Therefore, the two methods are different but complementary, since their combination allows the evaluation 
of the relative bioactivity of defined amounts of Fsh according to the biological stage of the animal.

The pituitary Fsh profiles of European male and female sea bass during sex differentiation and during the female reproductive cycle obtained with the immunoassay were similar to those obtained with the bioassay. However, the calculated concentrations (absolute values) were always higher with the immunoassay (Fig. 5A and 6A). One possible explanation could be related with the biopotency of the Fsh variant used as standard, since, in the bioassay, a more potent standard than the samples would result in an extrapolation of lower levels of concentration, moreover must be taken into account that the immunoassay recognizes Fshb and it does not distinguish between dimers (alpha-beta) or monomers (beta), whereas in the bioassay only the dimers (alpha-beta) are bioactive and, therefore, measured. The first histological signs of gonadal differentiation were observed around $150 \mathrm{dph}$ in females and $200 \mathrm{dph}$ in males, which coincided with the time that sex differentiation of the ovary and testes, respectively, was well underway [31]. At $250 \mathrm{dph}$, gonads were completely differentiated in females and males. In both sexes, plasma Fsh bioactivity levels were high at 150-200 dph and progressively decreased by $300 \mathrm{dph}$. In the pituitary, the profiles of Fsh quantity and bioactivity were exactly the opposite, increasing from 150-200 to $300 \mathrm{dph}$. These results indicate that high levels of Fsh could be required at initial stages of sexual differentiation. Thus, the data obtained suggest a high Fsh release in plasma at early stages followed by a later accumulation in pituitary. In this regard, previous studies performed on the same animals and during the same period showed that the maximum levels of $f s h b$ and cga pituitary expression were achieved at $200 \mathrm{dph}$, keeping high until 300 $\mathrm{dph}$, and they were higher than $l \mathrm{hb}$. Moreover, plasma levels of Lh were low at early stages, with an elevation only observed at $250 \mathrm{dph}$ when gonads were completely differentiated in both sexes [19]. On the other hand, the immunohistochemical analysis in this study revealed that, as in other teleost species $[16,37,38,39,40]$, Fsh and Lh in European sea bass are produced in different cell populations of the adenohypophysis. Moreover, in rainbow trout (Oncorhynchus mykiss), platyfish (Xiphophorus maculatus) and acará (Cichlasoma dimerus) it has been reported that the Fsh cells appeared prior to the onset of sexual differentiation, while Lh cells were observed several days after this process started or upon completion [12, 14, 15, 17]. Taken together, these data support a key role for Fsh during sex differentiation. 
Additionally, both plasma and pituitary European sea bass Fsh levels were higher in females than in males, and the pituitary B:I ratio during this period was also higher in females, suggesting a possible sexual dimorphism in the synthesis and potency of Fsh during sex differentiation of European sea bass. Expression analysis of cytochrome $\mathrm{P} 450$ aromatase genes in ovary (cyp19a1) and brain (cyp19a2) in the same fish populations and period [20, 41] showed that females exhibited higher expression levels than males, suggesting that the high levels of Fsh seen in this study could be involved in the control of their expression. The enzyme Cyp19a1 catalyzes the conversion of Testosterone ( $\mathrm{T}$ ) into E2 and previous studies have demonstrated a direct stimulation of cyp19a1 expression by Fsh in fish oocytes [42].

Regarding the annual cycle of sexually mature females, the Fsh quantity and bioactivity levels in the pituitary were significantly higher during late- and post-vitellogenesis and maturation-ovulation, with a tendency to decrease at the stage of atresia at the end of the reproductive season. In the plasma, Fsh bioactivity levels peaked at late- and post-vitellogenesis and declined gradually thereafter. This Fsh profile is concordant with those found in synchronous species. In coho salmon, Swanson [43] reported that plasma Fsh concentration increased during vitellogenesis, with the highest levels occurring during mid- to late-vitellogenesis, after which plasma Fsh decreased as ovulation approached. In rainbow trout, plasma Fsh levels increased significantly at the onset of vitellogenesis [44], being maintained during active vitellogenesis and decreasing prior to maturation [45]. On the other hand, when the pituitary content of European sea bass Lh was analyzed in the same samples of the female cycle, the quantity profile turned out to be identical to that of Fsh. Previously, in the same animals, the Lh and E2 plasma levels and gene expression of $f s h r, l h r$ and cyp19a1 were analyzed [23]. Correlation between $l h r$ receptor expression and its ligand levels was observed, Lh plasma levels and $l h r$ gene expression peaked at maturation-ovulation, whereas $f s h r$ gene expression exhibited very high levels at late- and postvitellogenesis coincident with the highest plasma levels of Fsh bioactivity (Rocha et al. [23] and this study, respectively). At maturation-ovulation $f s h r$ gene expression remained elevated and plasma Fsh bioactivity levels decreased although not significantly. The high levels of $f$ shr expression in the ovary [23] and the Fsh content in pituitary and bioactivity in plasma (this study) during maturation could be explained by the reproductive strategy of this species. European sea bass ovary exhibits a group-synchronous type of 
development and contains clutches of oocyte populations at various stages of secondary growth that are successively recruited for maturation [32, 46]. Therefore, during the maturation stage, Fsh would be needed by clutches of oocytes that are still in vitellogenesis. The data presented here indicate similar synthesis and accumulation of Fsh and Lh in the pituitary gland, but different release to the bloodstream. Moreover, the maximum of plasma FSH bioactivity observed here coincided with the maximum expression of cyp19a1 and E2 plasma levels reported earlier [23]. Estradiol is known to stimulate the hepatic synthesis of vitellogenin, which is then incorporated progressively into the growing oocytes during the period of gametogenesis [47]. Several studies have demonstrated that Fsh stimulates in vitro production of E2 in ovarian explants or isolated vitellogenic follicles [21, 42, 48, $49]$ and promotes the incorporation of vitellogenin into the oocytes [50, 51]. Therefore, according to the obtained results it appears that in the European sea bass, Fsh regulates the vitellogenesis by stimulation of the ovarian production of E2 via activation of Cyp19a1, whereas Lh would be responsible for the final events, such as oocyte maturation and ovulation.

In the pituitary of adult female European sea bass, the B:I ratio decreased as ovarian recrudescence progressed whereas the opposite occurred during sex differentiation. This observation was true for both ratios calculated from absolute values and relative values, keeping proportions between the two experiments. This could suggest the presence of Fsh isoforms in the pituitary, with different biopotencies associated to the reproductive stage of the animal. Studies in mammals have demonstrated that changes in the content of sialic acid affect the bioactivity of FSH isoforms. In humans, less acidic FSH isoforms exhibit higher B:I ratios than more acidic counterparts [52]. In rats it has also been suggested that more sialylated FSH isoforms are less biopotent whereas less acidic isoforms exhibit higher biopotency but shorter half-life in circulation [36]. Besides, it seems that intrapituitary FSH molecular microheterogenity may change depending on the age, sexual development or/and the steroidogenic milieu $[36,53]$. Our results seem to indicate that during sex differentiation Fsh isoforms with higher potency are needed, whereas less biopotent but possibly long-lived Fsh could be needed as ovarian growth progresses in adult females.

In conclusion, two homologous and specific assays have been developed to measure European sea bass Fsh in plasma and pituitary. The assays have provided, for the first time in a fish species, quantitative and qualitative in- 
formation on Fsh in critical moments of the reproductive life cycle. The obtained results reinforce the hypothesis that Fsh has an important role during sex differentiation of European sea bass. In addition, a sexual dimorphism in the synthesis and potency of Fsh is suggested. On the other hand, in adult females, a Fsh less biopotent form than that found during sex differentiation would regulate secondary oocyte growth (vitellogenesis), whereas Lh would be responsible for the final reproductive events, such as oocyte maturation and ovulation.

\section{Acknowledgments}

We thank Mrs. Soledad Ibáñez for her excellent technical work during the bioassay development.

\section{References}

1. Pierce JG, Parsons TF. Glycoprotein hormones: structure and function. Annu Rev Biochem 1981; 50: 465-495.

2. Bousfield GR, Perry WM, Ward DN. Gonadotropins. Chemistry and biosynthesis. In: Knobil, E., Neill, J. D. (eds.), The Physiology of Reproduction. New York: Raven Press; 1994: 1749-1792.

3. Suzuki K, Kanamori A, Nagahama Y, Kawauchi H. Development of salmon GTH I and GTH II radioimmunoassays. Gen Comp Endocrinol 1988; 71: 459-467.

4. Swanson P, Bernard M, Nozaki M, Suzuki K, Kawauchi H, Dickhoff WW. Gonadotropin-I and Gonadotropin-II in Juvenile Coho Salmon. Fish Physiol Biochem 1989; 7: 169-176.

5. Swanson P, Suzuki K, Kawauchi H, Dickhoff WW. Isolation and characterization of two coho salmon gonadotropins, GTH I and GTH II. Biol Reprod 1991; 44: 29-38.

6. Govoroun M, Chyb J, Breton B. Immunological cross-reactivity between rainbow trout GTH I and GTH II and their alpha and beta subunits: Application to the development of specific radioimmunoassays. Gen Comp Endocrinol 1998; 111:28-37.

7. Santos EM, Rand-Weaver M, Tyler CR. Follicle-stimulating hormone and its alpha and beta subunits in rainbow trout (Oncorhynchus mykiss): purification, characterization, development of specific radioimmunoassays, and their seasonal plasma and pituitary concentrations in females. Biol.Reprod. 2001; 65: 288-294.

8. Aizen J, Kasuto H, Levavi-Sivan B. Development of specific enzyme-linked immunosorbent assay for determining LH and FSH levels in tilapia, using recombinant gonadotropins. Gen Comp Endocrinol 2007; 153: 323-332.

9. Levavi-Sivan B, Bogerd J, Mañanós EL, Gómez A, Lareyre JJ. Perspectives on fish gonadotropins and their receptors. Gen Comp Endocrinol 2010; 165: 412-437.

10. Devlin RH, Nagahama Y. Sex determination and sex differentiation in fish: an overview of genetic, physiological, and environmental influences. Aquaculture 2002; 208: 191- 
364.

11. Kobayashi Y, Alam MA, Horiguchi R, Shimizu A, Nakamura M. Sexually Dimorphic Expression of Gonadotropin Subunits in the Pituitary of Protogynous Honeycomb Grouper (Epinephelus merra): Evidence That Follicle-Stimulating Hormone (FSH) Induces Gonadal Sex Change. Biol Reprod 2010; 82: 1030-1036.

12. Pandolfi M, Lo Nostro FL, Shimizu A, Pozzi AG, Meijide FJ, Vázquez GR, Maggese MC. Identification of immunoreactive FSH and LH cells in the cichlid fish Cichlasoma dimerus during the ontogeny and sexual differentiation. Anat Embryol 2006; 211: 355365.

13. Yamaguchi T, Yamaguchi S, Hirai T, Kitano T. Follicle-stimulating hormone signaling and Foxl2 are involved in transcriptional regulation of aromatase gene during gonadal sex differentiation in Japanese flounder, Paralichthys olivaceus. Biochem Biophys Res Commun 2007; 359: 935-940.

14. Feist G, Schreck CB. Brain-pituitary-gonadal axis during early development and sexual differentiation in the rainbow trout, Oncorhynchus mykiss. Gen Comp Endocrinol 1996; 102: 394-409.

15. Magliulo-Cepriano L, Schreibman MP, Blum V. Distribution of variant forms of immunoreactive gonadotropin-releasing hormone and beta-gonadotropins I and II in the platyfish, Xiphophorus maculatus, from birth to sexual maturity. Gen Comp Endocrinol 1994; 94: 135-150.

16. Miranda LA, Strussmann CA, Somoza GM. Immunocytochemical identification of GtH1 and GtH2 cells during the temperature-sensitive period for sex determination in pejerrey, Odontesthes bonariensis. Gen Comp Endocrinol 2001; 124: 45-52.

17. Saga T, Oota Y, Nozaki M, Swanson P. Salmonid Pituitary Gonadotrophs. III. Chronological appearance of GTH1 and other adenohypophyseal hormones in the pituitary of the developing rainbow trout (Oncorhynchus mykiss irideus). Gen Comp Endocrinol 1993; 92: 233-241.

18. Carrillo M, Zanuy S, Prat F, Cérda J, Mañanós E, Bromage NR. Sea bass (Dicentrarchus labrax). In: Bromage NR, Roberts RJ (eds.), Broodstock Management and Egg and Larval Quality. London: Blackwell Science; 1995: 138-168.

19. Molés G, Carrillo M, Mañanós E, Mylonas CC, Zanuy S. Temporal profile of brain and pituitary GnRHs, GnRH-R and gonadotropin mRNA expression and content during early development in European sea bass (Dicentrarchus labrax L.). Gen Comp Endocrinol 2007; 150: 75-86.

20. Piferrer F, Blazquez M, Navarro L, Gonzalez A. Genetic, endocrine, and environmental components of sex determination and differentiation in the European sea bass (Dicentrarchus labrax L.). Gen Comp Endocrinol 2005; 142: 102-110.

21. Molés G, Gómez A, Rocha A, Carrillo M, Zanuy S. Purification and characterization of follicle-stimulating hormone from pituitary glands of sea bass (Dicentrarchus labrax). Gen Comp Endocrinol 2008; 158: 68-76.

22. Molés G, Zanuy S, Muñoz I, Crespo B, Martínez I, Mañanós E, Gómez A. Receptor specificity and functional comparison of recombinant sea bass (Dicentrarchus labrax) gonadotropins (Fsh and Lh) produced in different host systems. Biol Reprod 2011 (DOI:10.1095/biolreprod.110.086470).

23. Rocha A, Zanuy S, Carrillo M, Gómez A. Seasonal changes in gonadal expression of gonadotropin receptors, steroidogenic acute regulatory protein and steroidogenic en- 
zymes in the European sea bass. Gen Comp Endocrinol 2009; 162: 265-275.

24. Christin-Maitre S, Bouchard P. Bioassays of gonadotropins based on cloned receptors. Mol Cell Endocrinol 1996; 125: 151-159.

25. Ulloa-Aguirre A, Timossi C, Barrios-de-Tomasi J, Maldonado A, Nayudu P. Impact of carbohydrate heterogeneity in function of follicle-stimulating hormone: Studies derived from in vitro and in vivo models. Biol Reprod 2003; 69: 379-389.

26. Albanese C, Christin-Maitre S, Sluss PM, Crowley WF, Jameson JL. Development of a bioassay for FSH using a recombinant human FSH receptor and a cAMP responsive luciferase reporter gene. Mol Cell Endocrinol 1994; 101: 211-219.

27. Christin-Maitre S, Taylor AE, Khoury RH, Hall JE, Martin KA, Smith PC, Albanese C, Jameson JL, Crowley WF, Sluss PM. Homologous in vitro bioassay for follicle-stimulating hormone (FSH) reveals increased FSH biological signal during the mid- to late luteal phase of the human menstrual cycle. J Clin Endocrinol Metab 1996; 81: 20802088.

28. Gudermann T, Brockmann H, Simoni M, Gromoll J, Nieschlag E. In-Vitro Bioassay for Human Serum Follicle-Stimulating-Hormone (FSH) Based on L-Cells Transfected with Recombinant Rat FSH Receptor: Validation of a Model System. Endocrinology 1994; 135: 2204-2213.

29. Kajitani T, Liu S, Maruyama T, Uchida H, Sakurai R, Masuda H, Nagashima T, Ono M, Arase T, Yoshimura Y. Analysis of serum FSH bioactivity in a patient with an FSHsecreting pituitary microadenoma and multicystic ovaries: A case report. Hum Reprod 2008; 23: 435-439.

30. Tano M, Minegishi T, Nakamura K, Karino S, Ibuki Y. Application of Chinese hamster ovary cells transfected with the recombinant human follicle-stimulating hormone (FSH) receptor for measurement of serum FSH. Fertil Steril 1995; 64: 1120-1124.

31. Papadaki M, Piferrer F, Zanuy S, Maingot E, Divanach P, Mylonas CC. Growth, sex differentiation and gonad and plasma levels of sex steroids in male- and female-dominant populations of Dicentrarchus labrax obtained through repeated size grading. J Fish Biol 2005; 66: 938-956.

32. Asturiano JF, Sorbera LA, Ramos J, Kime DE, Carrillo M, Zanuy S. Hormonal regulation of the European sea bass reproductive cycle: an individualized female approach. J Fish Biol 2000; 56: 1155-1172.

33. Rocha A, Gómez A, Zanuy S, Cerda-Reverter JM, Carrillo M. Molecular characterization of two sea bass gonadotropin receptors: cDNA cloning, expression analysis, and functional activity. Mol Cell Endocrinol 2007; 272: 63-76.

34. Mateos J, Mañanós E, Swanson P, Carrillo M, Zanuy S. Purification of luteinizing hormone (LH) in the sea bass (Dicentrarchus labrax) and development of a specific immunoassay. Cienc Mar 2006; 32: 271-283.

35. Christin-Maitre S, Vasseur C, Fauser B, Bouchard P. Bioassays of gonadotropins. Methods 2000; 21: 51-57.

36. Ambao V, Rulli SB, Carino MH, Console G, Ulloa-Aguirre A, Calandra RS, Campo S. Hormonal regulation of pituitary FSH sialylation in male rats. Mol Cell Endocrinol 2009; 309: 39-47.

37. Calman B, Lin YWP, Wallace RA. Preparation and use of specific antibodies to the beta-I and beta-II subunits of gonadotropic hormone from Fundulus heteroclitus pituitary. Gen Comp Endocrinol 2001; 123: 203-209. 
38. Garcia-Ayala A, Garcia-Hernandez MP, Quesada JA, Agulleiro B. Gonadotropic and thyrotropic cells from the Mediterranean yellowtail (Seriola dumerilii; Risso, 1810): Immunocytochemical and ultrastructural characterization. Anat Rec 1998; 250: 448458.

39. Kagawa H, Kawazoe I, Tanaka H, Okuzawa K. Immunocytochemical identification of two distinct gonadotropic cells (GTH I and GTH II) in the pituitary of bluefin tuna, Thunnus thynnus. Gen Comp Endocrinol 1998; 110: 11-18.

40. Nozaki M, Naito N, Swanson P, Dickhoff WW, Nakai Y, Suzuki K, Kawauchi H. Salmonid pituitary gonadotrophs. II. Ontogeny of GTH I and GTH II cells in the rainbow trout (Salmo gairdneri irideus). Gen Comp Endocrinol 1990; 77: 358-367.

41. Blazquez M, Piferrer F. Cloning, sequence analysis, tissue distribution, and sex-specific expression of the neural form of P450 aromatase in juvenile sea bass (Dicentrarchus labrax). Mol Cell Endocrinol 2004; 219: 83-94.

42. Montserrat N, González A, Mendez E, Piferrer F, Planas JV. Effects of follicle stimulating hormone on estradiol-17 beta production and P-450 aromatase (CYP19) activity and mRNA expression in brown trout vitellogenic ovarian follicles in vitro. Gen Comp Endocrinol 2004; 137: 123-131.

43. Swanson P. Salmon gonadotropins: reconciling old and new ideas. In: Scott AP, Sumpter JP, Kime DE, Rolfe MS (eds.), Reproductive Physiology of Fish, Sheffield: FishSymp; 1991: 2-7.

44. Prat F, Sumpter JP, Tyler CR. Validation of radioimmunoassays for two salmon gonadotropins (GTH I and GTH II) and their plasma concentrations throughout the reproductive cycle in male and female rainbow trout (Oncorhynchus mykiss). Biol Reprod 1996; 54: 1375-1382.

45. Breton B, Govoroun M, Mikolajczyk T. GTH I and GTH II secretion profiles during the reproductive cycle in female rainbow trout: Relationship with pituitary responsiveness to GnRH-A stimulation. Gen Comp Endocrinol 1998; 111: 38-50.

46. Mayer I, Shackley SE, Witthames PR. Aspects of the Reproductive-Biology of the Bass, Dicentrarchus labrax L .2. Fecundity and Pattern of Oocyte Development. J Fish Biol 1990; 36: 141-148.

47. Mañanós E, Zanuy S, Lemenn F, Carrillo M, Núñez J. Sea Bass (Dicentrarchus labrax L) Vitellogenin. I-Induction, purification and partial characterization. Comp Biochem Physiol B, Biochem Mol Biol 1994; 107: 205-216.

48. Planas JV, Athos J, Goetz FW, Swanson P. Regulation of ovarian steroidogenesis in vitro by follicle-stimulating hormone and luteinizing hormone during sexual maturation in salmonid fish. Biol Reprod 2000; 62: 1262-1269.

49. Suzuki K, Nagahama Y, Kawauchi H. Steroidogenic activities of two distinct salmon gonadotropins. Gen Comp Endocrinol 1988; 71: 452-458.

50. Tyler CR, Sumpter JP, Kawauchi H, Swanson P. Involvement of gonadotropin in the uptake of vitellogenin into vitellogenic oocytes of the rainbow trout, Oncorhynchus mykiss. Gen Comp Endocrinol 1991; 84: 291-299.

51. Tyler CR, Pottinger TC, Coward K, Prat F, Beresford N, Maddix S. Salmonid folliclestimulating hormone (GtH I) mediates vitellogenic development of oocytes in the rainbow trout, Oncorhynchus mykiss. Biol Reprod 1997; 57: 1238-1244.

52. Zambrano E, Barrios-de-Tomasi J, Cardenas M, UIIoa-Aguirre A. Studies on the relative in vitro biological potency of the naturally occurring isoforms of intrapituitary 
follicle stimulating hormone. Mol Hum Reprod 1996; 2: 563-571.

53. Rulli SB, Creus S, Pellizzari E, Cigorraga SB, Calandra RS, Campo S. Androgen regulation of immunological and biological activities of pituitary follicle-stimulating hormone isoforms in male rats. Neuroendocrinology 1999; 70: 255-260. 



\section{Capítulo 7:}

Development of homologous enzyme-linked immunosorbent assay for European sea bass FSH. Reproductive cycle plasma levels in both sexes and in yearling precocious and nonprecocious males

Gregorio Molés, Ana Gómez, Manuel Carrillo, Silvia Zanuy General and Comparative Endocrinology (en revisión) 



\begin{abstract}
Since the late 1980s, gonadotropins have been isolated and characterized in several fish species, but specific immunoassays for the follicle-stimulating hormone (FSH) have only been developed for a few. The present study reports the development and use of a specific and homologous competitive ELISA for measuring FSH in European sea bass (Dicentrarchus labrax) using a recombinant FSH and its specific antiserum. Recombinant European sea bass FSH $\beta$ and FSH dimer were produced in the methylotrophic yeast Pichia pastoris and a baculovirus expression system, respectively. Specific polyclonal antibodies, generated by rabbit immunization against recombinant FSH $\beta$, were used at a final dilution of 1:8000. Recombinant FSH dimer was used to generate a standard curve and for coating of microplates $(166 \mathrm{ng} / \mathrm{ml})$. The sensitivity of the assay was $0.50 \mathrm{ng} / \mathrm{ml}\left[\mathrm{B}_{0}-2 \mathrm{SD}\right]$, and the intra- and inter-assay coefficients of variation were $2.12 \%(\mathrm{n}=10)$ and $5.44 \%$ $(\mathrm{n}=16)\left(\mathrm{B}_{\mathrm{i}} / \mathrm{B}_{0} \sim 45 \%\right)$, respectively. A high degree of parallelism was observed between the standard curve and serially diluted plasma and pituitary samples of European sea bass.

The ELISA developed was used to study the plasma FSH profiles of mature males and females during the reproductive cycle, and those of immature juvenile males under different light regimes. The analysis showed that FSH increased significantly during the intermediate stages of spermatogenesis and during vitellogenesis. Analyses in immature juvenile males showed that the continuous light photoperiod significantly reduced plasma FSH levels, and consequently, testicular growth. In conclusion, the immunoassay developed has proven to be sensitive, specific and accurate for measuring European sea bass FSH, and it represents a valuable tool for future studies on the reproductive endocrinology of this species.
\end{abstract}

Keywords: FSH, recombinant, yeast, ELISA, reproductive cycle, Perciform 


\section{Introduction}

The gonadotropins (GTHs), follicle-stimulating hormone (FSH) and luteinizing hormone $(\mathrm{LH})$ are key hormones in the control of reproduction in vertebrates. These heterodimeric glycoproteins are synthesized and secreted by the pituitary gland. GTHs are formed by the non-covalent association of a common $\alpha$-subunit with distinct $\beta$-subunits that confer hormone specificity $[5,27]$. Each subunit is encoded by a single, separate gene [11], while dimerization and glycosylation are prerequisites for GTHs to achieve full biological activity.

As in higher vertebrates, fish GTHs regulate gametogenesis and steroidogenesis. In salmonids, from which most of the information on seasonal GTHs profiles comes, FSH is believed to regulate the early stages of gametogenesis, such as vitellogenesis and spermatogenesis, whereas LH is generally accepted to be the hormone responsible for the final maturation processes, such as oocyte maturation, ovulation and spermiation [15]. However, the functional duality between FSH and LH at critical moments in the reproductive process in other fish species has not yet been fully clarified, mainly due to a lack of appropriate research tools like assays to measure GTH levels. Traditionally, the immunoassays developed to determine GTH levels in fish have been radioimmunoassays (RIA) or enzyme-linked immunosorbent assays (ELISA) based on native GTHs purified from fish pituitaries, as well as their specific antibodies. The purification of native GTHs is a highly demanding process in terms of time, cost and the large number of pituitary glands required [15]. Since the late 1980s, GTHs have been isolated and characterized in several fish species, but homologous immunoassays for FSH have only been developed for three fish species with synchronous ovarian development: chum salmon (Oncorhynchus keta) [37], coho salmon (Oncorhynchus kisutch) [40, 41] and rainbow trout (Oncorhynchus mykiss) [12]. For other fish species, quantitative tools like these have only been available for LH, a fact that has hampered studies. Over the last decade, the isolation and characterization of cDNAs encoding GTH subunits in a wide range of fish species has made it possible to produce species-specific recombinant GTHs. The production of recombinant GTHs represents a good alternative to native hormones, as they can be continuously produced, ensuring their availability and preventing cross-contamination with other related glyco- 
proteins [15]. However, over the last few years, homologous immunoassays for FSH and LH using recombinant gonadotropins have been successfully developed for only one perciform species with asynchronous ovarian development: the tilapia (Oreochromis niloticus) [1].

The European sea bass (Dicentrarchus labrax) is a marine perciform fish with a group-synchronous ovarian type development [9], and there is information available on the endocrine control of its reproductive function, particularly regarding the role of $\mathrm{LH}$ in adults $[24,25,30]$ and juveniles [31, 32]. Nevertheless, there is a lack of information on the role of FSH in either adults or juveniles. The European sea bass is a very important species for intensive aquaculture, and under these conditions, a large number of males anticipate puberty just after sexual differentiation [33]. In light of this, precocity becomes one of the most significant problems to be solved, since these fish experience growth depletion and vulnerability to diseases [43]. Several works have demonstrated the effectiveness of photoperiod in preventing early puberty in male European sea bass [6,31]. Nevertheless, further studies are needed to understand the underlying mechanisms of this inhibition, in particular with regard to the role of FSH.

Recently, we have produced recombinant European sea bass FSH $\beta$ subunit in a baculovirus expression system and developed a dot-blot immunoassay capable of measuring FSH in pituitary samples [22]. However, this assay could not be validated for plasma, because plasma FSH levels were often below the assay detection limit.

The objectives of this study were threefold: (1) the production of a new batch of recombinant European sea bass FSH $\beta$ in the methylotrophic yeast Pichia pastoris and the generation of its specific antibodies; (2) the development of a more sensitive and versatile immunoassay for European sea bass FSH, capable of determining FSH levels in both plasma and pituitary samples; and (3) to study the plasma FSH profiles in adult males and females during the reproductive cycle, and in juvenile males under different light regimes.

\section{Materials and methods}

\subsection{Experimental fish and sample collection}

Male and female European sea bass from the stock raised at the facili- 
ties of the Torre de la Sal Aquaculture Institute $\left(40^{\circ} \mathrm{NL}\right)$ were used to study seasonal profiles during the reproductive cycle. Fish were sampled monthly throughout the entire period of their first sexual maturation. At each sampling point, five fish of each sex were anesthetized, weighed, measured and sacrificed. Blood was collected via a caudal vein puncture using heparinized syringes, centrifuged at $2500 \mathrm{~g}$ for $25 \mathrm{~min}$ at $4^{\circ} \mathrm{C}$ and plasma stored at $-20^{\circ} \mathrm{C}$ until the time of analysis. Pituitaries were extracted, immediately frozen in liquid nitrogen and stored at $-80^{\circ} \mathrm{C}$. For analysis, pituitaries were mechanically homogenized in TBS-T (10 mM Tris-base, $150 \mathrm{mM} \mathrm{NaCl}$ and $0.05 \%$ Tween-20) using sterile syringes. The extract was centrifuged (3000 $g$ for 15 min at $4{ }^{\circ} \mathrm{C}$ ) to eliminate debris and stored at $-80^{\circ} \mathrm{C}$ until assayed. Gonads were dissected, fixed, sectioned $(3 \mu \mathrm{m})$ and stained according to the method described by Bennett et al. [4] for histological analysis. The stages of testicular development were classified by means of light microscopy, following previously established criteria [6]: stage I, immature testes; stage II-IV, testicular growth (early, mid and late recrudescence); stage V, fully spermiating testes and stage VI, post-spawning. The ovarian stages were classified as described by Rocha et al. [30], following previously established criteria [3]: previtellogenesis (prevtg); early vitellogenesis (evtg); late-vitellogenesis and post-vitellogenesis (lvtg-pvtg); maturation-ovulation (mat-ovul) and atresia (atre).

Juvenile male European sea bass (seven months of age) obtained from Aquanord (Gravelines, France) were used to study the effect of a continuous light regime, which is known to impair precocious puberty in males [6], in terms of plasma FSH levels. Immature juvenile males were subjected to either simulated natural photoperiod (NP) or continuous light (LL) (24h light/day) treatments for ten months (June-March). In October, December, January and March, 13 fish from each group were anesthetized, weighed, measured and sacrificed. Blood was collected as described above.

All fish were sacrificed in accordance with Spanish legislation concerning the protection of animals used for experimentation and other scientific purposes.

\subsection{Construction of FSH $\beta$ expression plasmid}

Complementary DNA fragments containing the entire open reading frame (ORF) of mature European sea bass FSH $\beta$ (480 bp) (GenBank ac- 
cession number: AF543314) and a C-terminal 6xHis tag were obtained by PCR, using specific primers (Forward: 5'GG GAATTC GGG CAG GGC TGC AGC TTC3'; Reverse: 5’AT GCGGCCGC TTA ATG ATG ATG ATG ATG ATG AAA GGA CAG ACA GCT GGG TAT3') and the proofreading PfuTurbo DNA polymerase (Stratagene). Restriction sites were added at the 5 ' end of the forward and reverse primers. The fragment was directionally cloned into the donor plasmid pPIC9K (Invitrogen) between EcoRI / NotI restriction sites. The pPIC9K plasmid contains the yeast AOX1 promoter followed by the $\alpha$-Factor signal sequence, which directs the recombinant protein to the secretory pathway. The pPIC9K-FSH $\beta$ construct was sequenced to confirm its identity.

\subsection{Recombinant FSH $\beta$ production in yeast}

The pPIC9K-FSH $\beta$ construct was linearized with BglII and used to transform methylotrophic yeast Pichia pastoris, strain GS115 (Invitrogen), by electroporation, using an ECM 830 Electroporation system (BTX). The host strain GS115 has a mutation in the histidinol dehydrogenase gene (his4) that prevents it from synthesizing histidine. The pPIC9K expression plasmid complements his 4 in the host, so 85 transformants were selected for their ability to grow on histidine-deficient MD medium (1.5\% agar, $2 \%$ dextrose, $1.34 \%$ yeast nitrogen base, $4 \times 10^{-5} \%$ biotin). The pPIC9K plasmid contains the bacterial kanamycin gene that confers resistance to the antibiotic G418 (Geneticin; Invitrogen). Due to the fact that multiple plasmid integration events may increase the levels of expressed recombinant protein, the transformants were further screened for high resistance to G418 on YPD medium (2\% agar, 1\% yeast extract, $2 \%$ peptone, $2 \%$ dextrose and G418 at various concentrations $(0.5-2 \mathrm{mg} / \mathrm{ml}))$. Screening of $\mathrm{FSH} \beta$ production was performed by Western blot analysis. The clones with the highest production levels were cultured to examine the time-course of FSH $\beta$ synthesis. Initially they were grown in BMGY medium (1\% yeast extract, $2 \%$ peptone, $1.34 \%$ yeast nitrogen base, $1 \%$ glycerol, $4 \times 10^{-5} \%$ biotin and $100 \mathrm{mM}$ potassium phosphate, $\mathrm{pH}$ 6) under shaking for $21 \mathrm{~h}$ at $29^{\circ} \mathrm{C}$. The cells were then harvested by centrifugation at $2000 \mathrm{~g}$ for $5 \mathrm{~min}$ at room temperature (RT) and afterwards re-suspended and cultured in 1/4 volume of BMMY medium (BMGY with $0.5 \%$ methanol instead of $1 \%$ glycerol). Incubation continued for another $144 \mathrm{~h}$ at $29^{\circ} \mathrm{C}$, and methanol was added at a concentration of 
$0.5 \%$ every $24 \mathrm{~h}$ (induction phase). Samples of the culture supernatant were collected at different times $(0,24,48,72,96$, and $144 \mathrm{~h})$ by centrifugation at $15000 \mathrm{~g}$ for $3 \mathrm{~min}$ at RT and analyzed by FSH dot-blot immunoassay. As a negative control, GS115 cells were transformed using an expression plasmid without the sea bass FSH $\beta$ cDNA and treated in the same manner.

\subsection{FSH dot-blot immunoassay analysis}

The production level of FSH $\beta$ during the time course was measured by homologous FSH dot-blot immunoassay according to Molés et al. [22]. This assay has a sensitivity of $162 \mathrm{ng} / \mathrm{ml}$, with intra- and inter-assay coefficients of variation of $9.8 \%$ and $11.5 \%$, respectively.

\subsection{Recombinant FSH $\beta$ purification}

The European sea bass FSH $\beta$ was produced and harvested at $72 \mathrm{~h}$ after induction by methanol. The supernatant (1L) of a culture of GS115-FSH $\beta$ clone 6 was concentrated (5-6 ml) by ultrafiltration using Centricon Plus-70 Biomax 5 centrifugal filter devices (Amicon, Millipore) and later purified by immobilized metal affinity chromatography (IMAC Ni ${ }^{2+}$ ) using His GraviTrap prepacked columns (GE Healthcare), according to the manufacturer instructions. Briefly, the $\mathrm{pH}$ of the supernatant was adjusted to 7-8 with diluted acetic acid and the prepacked columns were equilibrated with PBS (20 mM sodium phosphate, $500 \mathrm{mM} \mathrm{NaCl}$, pH 7.4) containing $20 \mathrm{mM}$ imidazole. After loading the concentrated supernatant, two washings with PBS (20 $\mathrm{mM}$ and $70 \mathrm{mM}$ imidazole) were performed. Finally, the bound FSH $\beta$ was eluted with PBS containing $250 \mathrm{mM}$ imidazole. The purity of the fractions obtained was analyzed by sodium dodecyl sulfate-polyacrylamide gel electrophoresis (SDS-PAGE) and Western blot analysis.

\subsection{SDS-PAGE and Western blot analysis}

Proteins were electrophoresed through 15\%-SDS-PAGE gels under reducing conditions (5\% 2-mercaptoethanol (2-ME)). The separated proteins were stained with Coomassie blue or transferred to PVDF membranes (Immobilon P, Millipore). The membranes were blocked overnight with $5 \%$ skim milk at $4^{\circ} \mathrm{C}$, incubated with 1:3000 antibodies against European sea bass 
FSH $\beta$ (AbFSH $\beta-1)$ [22] for 90 min at room temperature, washed, and further incubated with 1:2000 goat anti-rabbit IgG-horseradish peroxidase conjugate (GAR-HRP, Bio-Rad) for $60 \mathrm{~min}$ at room temperature. The immunodetection was performed by chemiluminescence (Western Blotting Luminol Reagent, Santa Cruz Biotechnology, Inc.).

\subsection{European sea bass FSH $\beta$ antibody production}

Polyclonal antibodies against the purified recombinant FSH $\beta(\mathrm{AbFSH} \beta-2)$ were produced by a commercial company (Agrisera, Sweden). Two rabbits were immunized with $150 \mu \mathrm{g}$ of FSH $\beta$ in Freund's complete adjuvant by subcutaneous injection. Four subsequent immunizations (II-V) were carried out with $30 \mu \mathrm{g}$ of antigen in Freund's incomplete adjuvant at 3-week intervals. Rabbits were bled 2 weeks before immunizations (pre-immune serum) and 2 weeks after immunizations III, IV and V, in order to perform the corresponding titration test. The final bleeding was performed 2 weeks after the fifth immunization.

\subsection{European sea bass FSH ELISA}

A competitive ELISA for sea bass FSH determination was developed using the specific antiserum generated $(\mathrm{AbFSH} \beta-2)$ and recombinant FSH dimer produced in a baculovirus expression system [21]. The protocol was based on that previously described for ELISAs of striped bass LH [17] and sea bass LH [18], and was adapted as follows:

1) Coating. Polystyrene ELISA 96-well microplates (Maxisorp, Nunc) were coated with $50 \mu \mathrm{l} /$ well of recombinant European sea bass FSH dimer solution (166.5 ng/ml, diluted in sodium carbonate buffer 0.05 M, pH 9.6) overnight at $4^{\circ} \mathrm{C}$. Three wells were coated with the same concentration of bovine serum albumin (BSA, Sigma) to determine the non-specific binding. After coating, the wells were washed ( $3 \times 1 \mathrm{~min}$ ) with PBST (sodium phosphate buffer $0.01 \mathrm{M}, \mathrm{pH} 7.2$, containing $0.9 \% \mathrm{NaCl}$ and $0.05 \%$ Tween-20). The plate wash was repeated after every step of the assay.

2) Blocking. To reduce background, wells were blocked with $100 \mu \mathrm{l} /$ well of PBST buffer containing $2 \%$ BSA for $30 \mathrm{~min}$ at $37^{\circ} \mathrm{C}$. 
3) Incubation with primary antibodies. Before distribution into the wells, standard and unknown samples (final dilution 1:4 for plasma and 1:4000 for pituitary) were first preincubated with AbFSH $\beta-2$ (final dilution $1 / 8000$ ) in microcentrifuge tubes (overnight at $4^{\circ} \mathrm{C}$ ). The standard curve ranged from 0.32 to $162.5 \mathrm{ng} / \mathrm{ml}$ of sea bass FSH. All standards, samples and the antiserum solution were diluted in PBST buffer containing $2 \%$ normal goat serum (NGS, Sigma). After preincubation, samples and standards were dispensed in duplicate $(50 \mu \mathrm{l} /$ well $)$ into the coated wells and incubated for $48 \mathrm{~h}$ at $4^{\circ} \mathrm{C}$ without shaking. The non-specific binding wells and five FSH coated wells (maximum binding, $\mathrm{B}_{0}$ ) received only AbFSH $\beta-2$ solution.

4) Incubation with secondary antibodies. The antigen-antibody complexes formed were detected by incubation with $50 \mu \mathrm{l} /$ well of GAR-HRP, diluted 1:1000 in PBST-2\% NGS buffer for $1 \mathrm{~h}$ at $37^{\circ} \mathrm{C}$.

5) Color development. The presence of enzyme complexes was detected by the addition of $100 \mu \mathrm{l} /$ well of TMB reagent (Bio-Rad). The reaction was carried out in complete darkness at RT for $25 \mathrm{~min}$, and was stopped with $100 \mu \mathrm{l} /$ well of $1 \mathrm{~N}$ sulphuric acid. Absorbances were read after $5 \mathrm{~min}$ at $450 \mathrm{~nm}$, using an automatic microplate reader (Bio-Rad).

\subsection{Data representation and Statistical analysis}

To study the FSH profiles of males and females during the reproductive cycle, the samples were grouped according to gonadal stage of development (see Section 2.1). Data are presented as mean \pm SEM. The significance of the differences between group means of hormone levels was determined by one-way analysis of variance (ANOVA) followed by post hoc testing using the Holm-Sidak method, performed with SigmaStat 3.5 software (Systat Software Inc.). When the test of equal variance failed, an ANOVA on Ranks (Kruskal-Wallis) was performed, followed by all pairwise multiple comparison procedures (Dunn's method).

For ELISA data calculations, sigmoid curves were linearized using the logit transformation $\left(\operatorname{logit}\left(\mathrm{B}_{\mathrm{i}} / \mathrm{B}_{0}\right)=\ln \left(\mathrm{B}_{\mathrm{i}}-\mathrm{NSB} / \mathrm{B}_{0}-\mathrm{B}_{\mathrm{i}}\right)\right)$, where $\mathrm{B}_{\mathrm{i}}$ represents the binding of each point, $\mathrm{B}_{0}$ is the maximum binding and NSB the nonspecific binding. 


\section{Results}

\subsection{Production of Recombinant European sea bass FSH $\beta$}

The pPIC9K-FSH $\beta$ construct was used to transform GS115 cells by electroporation. Transformants were selected for their ability to grow on histidine-deficient MD medium and according to their resistance to high doses of G418. Thirteen colonies with $\mathrm{His}^{+} \mathrm{Mut}^{+}$phenotype and resistance to $2 \mathrm{mg}$ / $\mathrm{ml} \mathrm{G418} \mathrm{were} \mathrm{selected} \mathrm{and} \mathrm{used} \mathrm{for} \mathrm{screening} \mathrm{FSH} \beta$ production by Western blot analysis. A candidate protein reacted intensely with the AbFSH $\beta-1$ antibody [22] in all the colonies analyzed (Fig. 1). Yeast transformed with the vector alone served as a negative control and yielded no band (Fig. 1). The clones that produced the highest amount of recombinant FSH $\beta$ were selected and examined for time-course production and secretion of FSH $\beta$. Samples of culture supernatant were collected at different times $(0,24,48$, 72 , 96, and $144 \mathrm{~h}$ ) and subjected to dot-blot immunoassay analysis, which revealed that the yields of FSH $\beta$ increased up to $48 \mathrm{~h}$ after induction with methanol and remained constant between 72 and $144 \mathrm{~h}$ (Fig. 2). The clone with highest level of production was cultured to large scale for $72 \mathrm{~h}$. After the purification process, the collected fractions were analyzed by SDS-PAGE and Western blot. The Coomassie blue stain showed a production with a high yield and good degree of purity. A single band was intensely stained, although proteins of lower molecular weight were also observed (Fig. 3A). A

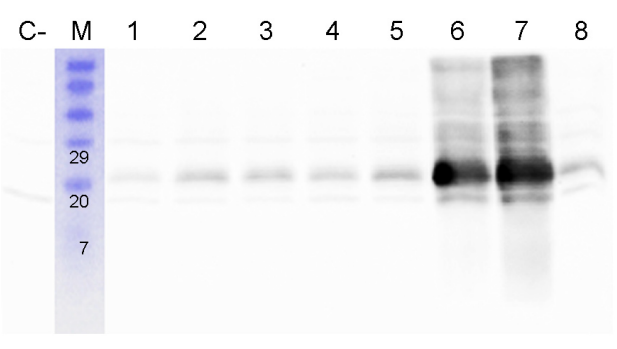

Figure 1. Screening of yeast FSH $\beta$ production. Analysis by Western blot with AbFSH $\beta-1$. Lanes 1-8: Cell lysates $(15 \mu \mathrm{l})$ from different GS115 colonies transformed with pPIC9K-FSH $\beta$. C-: Negative control; Cell lysate $(15 \mu \mathrm{l})$ from a colony containing pPIC9K. M: Bio-Rad prestained Broad Range molecular weight marker. 
Western blot analysis confirmed that the purified protein and the low molecular weight products were FSH $\beta$ (Fig. 3B), indicating that some protein degradation may have taken place. The molecular weight detected for FSH $\beta$ produced in yeast turned out to be slightly higher than that of the FSH $\beta$ previously produced in the baculovirus system (Fig. 3A). The purified FSH $\beta$ was used to generate specific polyclonal antibodies through rabbit immunizations. The antiserum produced was tested in Western blot, and specifically immunoreacted with pituitary extract and recombinant European sea bass FSH $\beta$ forms produced in yeast and the baculovirus system, but did not recognize recombinant European sea bass LH (Fig. 4), indicating the FSH $\beta$ specificity of the antibodies.

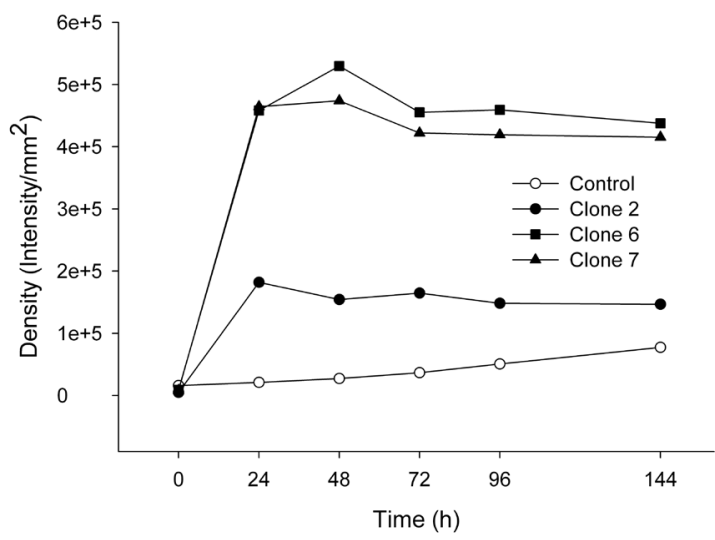

Figure 2. Time-course of yeast FSH $\beta$ production. Analysis by FSH dot-blot immunoassay of three GS115 clones expressing FSH $\beta$ and one wild type control. Each point is the mean of two replicates ( $250 \mu \mathrm{l}$ supernatant/sampling point).

\subsection{Development and validation of an ELISA for European sea bass FSH}

A homologous competitive ELISA was developed for FSH determination in pituitary and plasma samples, using recombinant FSH dimer for coating and the standard curve, and the specific antiserum generated (AbFSH $\beta-2)$ for immunodetection. A series of tests were performed to optimize the ELISA protocol by studying the behavior of the standard curve under different temperatures, incubation times and coating concentrations. 
A

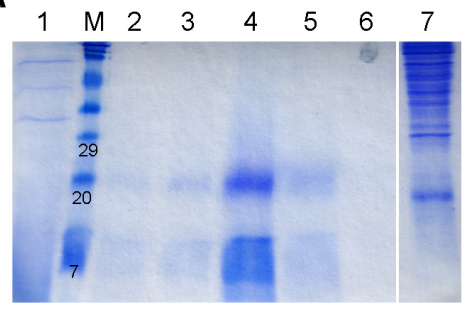

B

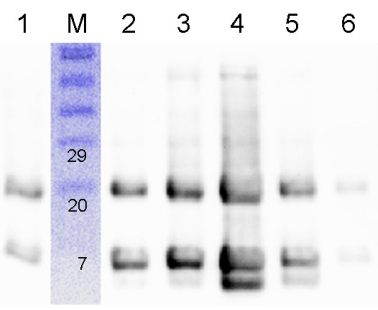

Figure 3. SDS-PAGE and Western blot analysis of purified recombinant European sea bass FSH $\beta$. A) Staining with Coomassie blue and B) Western blot with AbFSH $\beta-1$ after affinity chromatography (IMAC Ni $i^{2+}$ ) of recombinant FSH $\beta$ produced in yeast (GS115). Lane 1: Flowthrough $(10 \mu \mathrm{l})$; Lane 2 : Wash with PBS containing $70 \mathrm{mM}$ Imidazole $(20 \mu \mathrm{l})$; Lanes 3 to 6: Elution with PBS containing $250 \mathrm{mM}$ Imidazole $(20 \mu \mathrm{l})$; Lane 7: Elution with PBS containing $500 \mathrm{mM}$ Imidazole of FSH $\beta$ produced in baculovirus system $(20 \mu \mathrm{l})$. M: Bio-Rad prestained Broad Range molecular weight marker.

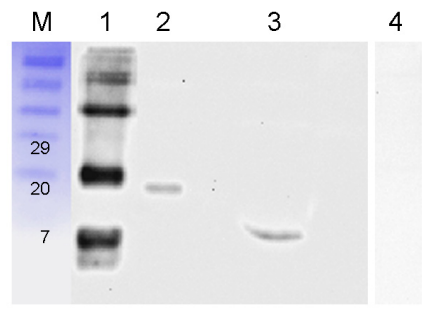

Figure 4. Analysis by Western blot of the polyclonal antibodies against recombinant European sea bass FSH $\beta$ produced in yeast (AbFSH $\beta-2 ; 1: 15000)$. Lane 1 : FSH $\beta$ produced in yeast (GS115) (100 ng), Lane 2: Pituitary extract (300 ng), Lane 3: FSH $\beta$ of FSH dimer produced in baculovirus system $(320 \mathrm{ng}$ ). Lane 4: LH dimer produced in baculovirus system (420 ng). M: Bio-Rad prestained Broad Range molecular weight marker.

Under optimized conditions, described in Materials and methods, the sensitivity of the assay, defined as the lowest dose of FSH capable of reducing the optical density more than the mean plus 2 standard deviations of the zero dose of FSH $\left[\mathrm{B}_{0}-2 \mathrm{SD}\right]$, was $0.50 \mathrm{ng} / \mathrm{ml}\left(\mathrm{B}_{\mathrm{i}} / \mathrm{B}_{0}>93,9 \%\right)$. The half maximum displacement occurred at $11.32 \mathrm{ng} / \mathrm{ml}\left(\mathrm{B}_{\mathrm{i}} / \mathrm{B}_{0}=50 \%\right)$.

The precision of the assay was tested by calculating the intra- and interassay coefficients of variation $(\mathrm{CV})$. The intra-assay $\mathrm{CV}$, tested by measuring replicates of the same sample in a single assay plate, was $4.7,2.1$ or $1.4 \%$, according to the calculations at 25,48 or $74 \%$ of binding, respectively $(n=10)$. 
The inter-assay $\mathrm{CV}$, calculated by measuring the same sample in different assays was $8.6,5.4$ or $3 \%$, according to the calculations at 23,44 or $83 \%$ of binding, respectively ( $\mathrm{n}=16)$.

The specificity of the assay was tested by cross-reaction of AbFSH $\beta-2$ with recombinant European sea bass LH produced in a baculovirus expression system [21], which showed no immunoreaction even at concentrations as high as $1000 \mathrm{ng} / \mathrm{ml}$ (Fig 5A).

Finally, the assay was validated for European sea bass plasma and pituitary samples by testing the parallelism with the standard curve. Displacement curves obtained with serial dilutions of plasma and pituitary extracts produced sigmoid curves similar to the FSH standard curve (Fig. 5A). In order to test the possibility of using the European sea bass FSH ELISA for FSH measurements in other fish species, displacement curves of serial dilutions of pituitary extracts and plasma from other fish species were compared with the FSH standard curve. A scarce or non-linear parallelism with the FSH standard curve was observed for thicklip grey mullet (Chelon labrosus), sea bream (Sparus aurata) and Senegalese sole (Solea senegalensis), which shows the high degree of specificity of AbFSH $\beta-2$ for European sea bass FSH (Fig. 5B).

\subsection{Determination of FSH levels}

FSH levels during the European sea bass reproductive cycle

Plasma profiles of FSH were examined throughout the first reproductive cycle of both sexes, which occurred during the second and third year of life in males and females, respectively. In males, FSH levels increased significantly during active spermatogenesis (stages II-IV) and fell to baseline levels just before full spermiation (stage V) (Fig. 6A). In females, the FSH levels peaked at vitellogenesis and post-vitellogenesis, while the minimum values were detected at maturation-ovulation (Fig. 6B). In both sexes, the baseline levels of FSH were higher than $15 \mathrm{ng} / \mathrm{ml}$.

FSH levels of juvenile European sea bass under different light regimes

Plasma FSH levels of juvenile European sea bass exposed to simulated natural photoperiod (control group) or continuous light were examined from October to March. The analysis showed that continuous light significantly reduced plasma FSH levels as compared to the control group. Under 

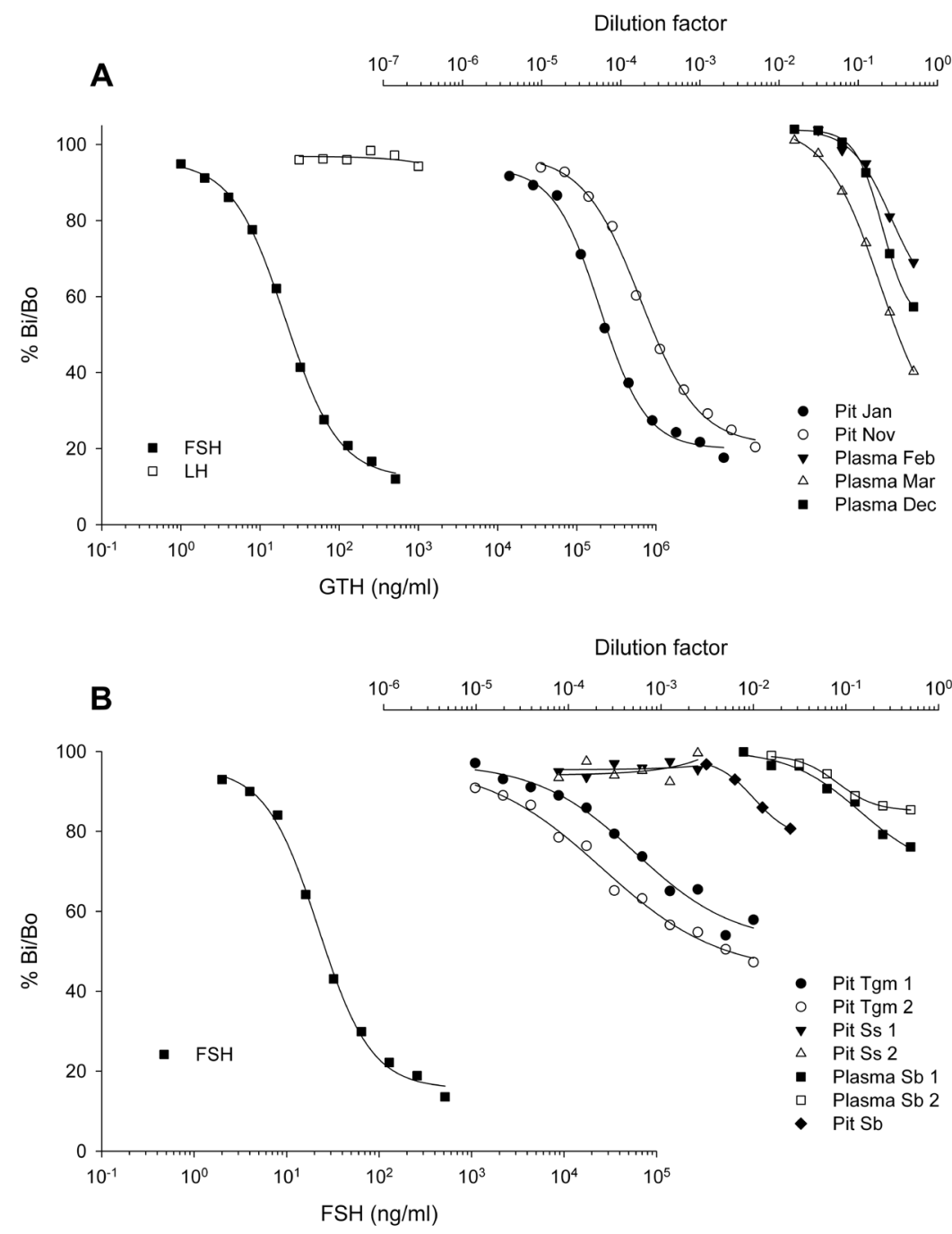

Figure 5. Validation of European sea bass FSH ELISA. A) Parallelism between FSH standard curve and displacement curves obtained with serial dilutions of plasma, pituitary extracts (Pit) and recombinant European sea bass LH. B) Parallelism between standard curve and displacement curves obtained with serial dilutions of plasma and pituitary extracts from different fish (1 and 2). Thicklip grey mullet (Tgm), sea bream (Sb) and Senegalese sole (Ss). Each point is the mean of two replicates. 
natural photoperiod, plasma FSH levels increased steadily until reaching their maximum level in March, while FSH levels of fish subjected to continuous light, remained unchanged (Fig. 7). The percentage of precocious juvenile males in the control group was about $65 \%$, on the contrary, under a regime of continuous light, the number of premature males was much lower, about $10 \%$ (data not shown).
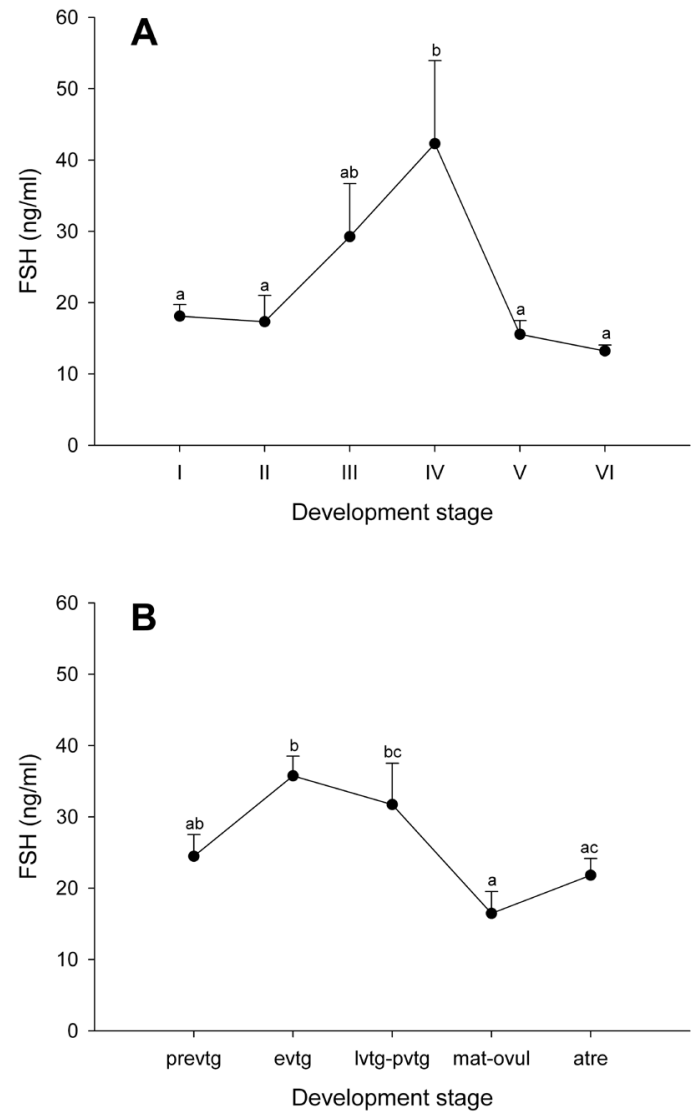

Figure 6. Seasonal profiles of plasma FSH in male and female European sea bass during the reproductive cycle. Values were classified according to stage of gonadal development as determined by histology. A) Males: immature (I); early recrudescence (II); mid recrudescence (III); late recrudescence (IV); fully spermiating (V) and post-spawning (VI). B) Females: previtellogenesis (prevtg); early vitellogenesis (evtg); late- and post-vitellogenesis (lvtg-pvtg); maturation-ovulation (mat-ovul) and atresia (atre). Points represent mean \pm SEM values $(n=$ $5-19$, depending on the stage). Different letters indicate significant differences between developmental stages $(\mathrm{P}=0.05)$. 


\section{Discussion}

This study describes the development and use of a specific and homologous ELISA for European sea bass FSH, using recombinant FSH and its specific antiserum. In teleosts, homologous immunoassays for FSH have only been developed for three salmonid species and one perciform species $[1$,

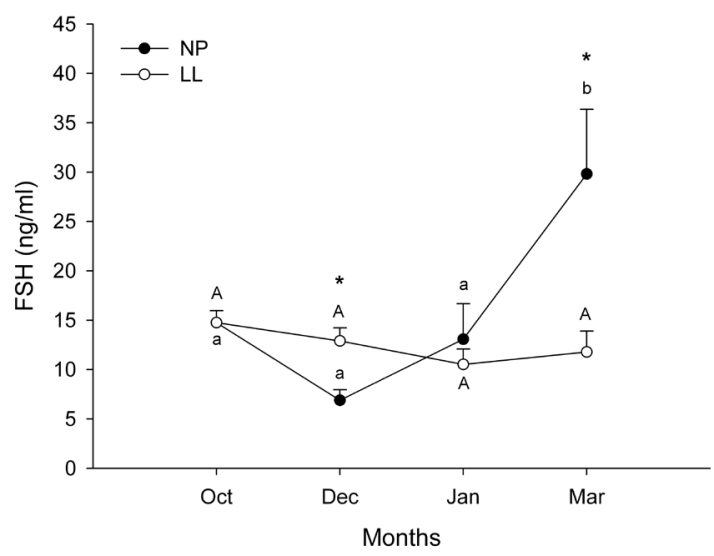

Figure 7. Plasma FSH levels in immature males of European sea bass exposed to simulated natural photoperiod (NP) or continuous light (LL) regimes for ten months (between June and March). Points represent mean \pm SEM ( $n=5-9$, depending on the sampling point). Different letters indicate significant differences between sampling points $(\mathrm{P}=0.05)$ (lowercase letters for NP and capital letters for LL). Asterisks indicate significant differences between the two treatments at equivalent sampling points $(\mathrm{P}<0.05)$.

$12,37,40]$. Traditionally, the immunoassays developed to determine GTHs levels in fish have been based on native GTHs purified from fish pituitaries and their specific antibodies. Since purification of native FSH is a very demanding process, the production of recombinant forms is a good alternative that yields large quantities of protein, ensuring its availability and no cross-contamination with other related glycoproteins. In the present study, we have developed a sensitive and versatile immunoassay for FSH, an ELI$\mathrm{SA}$ able to measure FSH in plasma and pituitary samples. For this purpose, we produced recombinant European sea bass FSH $\beta$ in the methylotrophic yeast Pichia pastoris, which was used to generate specific antibodies. Prior to this, we had produced recombinant European sea bass FSH dimer and 
FSH $\beta$ subunit using a baculovirus expression system [21, 22], as well as its specific antibodies (AbFSH $\beta-1)$. However, AbFSH $\beta-1$ reacted very weakly with FSH under native conditions; in spite of which we were still able to develop a dot-blot immunoassay capable of measuring pituitary FSH under denaturalized conditions. Nevertheless, to develop a more sensitive and versatile ELISA-like immunoassay, it was necessary to produce new antibodies that could recognize native forms of FSH. Accordingly, a new batch of recombinant FSH $\beta$ was produced in a yeast system. The main advantage of this system, compared to the baculovirus system previously used [22], is that the FSH $\beta$ was efficiently secreted and easily purified from the culture medium, although the production yield in yeast was somewhat lower than in the baculovirus system. In addition, yeast culture does not require costly sophisticated growing media and is fairly easy to establish and scale up.

The size of recombinant FSH $\beta$ generated in yeast was slightly higher than that previously produced in the baculovirus system. This fact might be due to different degrees of glycosylation, since Pichia pastoris have mostly a high-mannose-type N-linked glycosylation [13] while insect cells, used in the baculovirus system, assemble insect-specific paucimannose-type Nglycans [14].

To develop the FSH specific ELISA, recombinant FSH dimer [21] was used as coating and to generate the standard curve. The ELISA developed for European sea bass FSH showed optimal characteristics in terms of precision, specificity and sensitivity, similar to those reported for other fish GTH immunoassays. The precision was high, ensured by low intra- and interassay coefficients of variation, which were both below $5 \%$ and $9 \%$, respectively. These variations are lower or similar to those reported for FSH immunoassays in other fish species, which are in the range of 4-8\% and $10-12 \%$ for intra- and inter-assay CVs, respectively $[1,12,37]$. The specificity was demonstrated by the absence of AbFSH $\beta-2$ immunoreaction with European sea bass LH; no cross-reactivity was detected in either the Western blot or ELISA. Finally, the sensitivity of the European sea bass FSH ELISA (0.50 ng / $\mathrm{ml}$ ) was much higher than that of the FSH dot-blot immunoassay previously developed (162 ng/ml) [22], and high enough to measure plasma FSH levels. Moreover, the sensitivity was comparable to those reported for other fish GTH immunoassays, which ranged from 0.2 to $2.34 \mathrm{ng} / \mathrm{ml}$ for RIAs [12, 29, $35,37,40,42]$ and $0.24 \mathrm{pg} / \mathrm{ml}$ to $0.65 \mathrm{ng} / \mathrm{ml}$ for ELISAs[1, 17, 18, 34]. 
The European sea bass FSH ELISA was validated for plasma and pituitary samples by testing the parallelism with the standard curve. The results indicated that native sea bass FSH, both in blood and the pituitary, was parallel to the recombinant FSH dimer used in the standard curve, and therefore was immunologically similar. We also tested the usefulness of the developed European sea bass FSH ELISA to measure FSH in the pituitary and plasma of other fish species. Non-linear parallelism was observed between the FSH standard curve and the pituitaries of Senegalese sole, and scarce parallelism with thicklip grey mullet and sea bream pituitaries. It can therefore be determined that AbFSH $\beta-2$ has a high degree of specificity for European sea bass FSH, and is therefore not suitable to measure FSH levels in either the pituitary or the plasma of these species.

The ELISA developed was used to analyze, for the first time, immunological plasma FSH levels in a marine perciform with multiple-batch groupsynchronous ovarian development, the European sea bass. In adult males, the plasma levels of FSH increase during testicular growth (II-IV stages) and decline just before full spermiogenesis-spermiation (V stage), suggesting that in European sea bass, FSH plays an important role in the regulation of early-mid phases of spermatogenesis, but not in spermiogenesis and spermiation. The plasma levels of 11-Ketotestosterone (11-KT) and LH have been previously analyzed in the same animals [30]. The 11-KT profile coincided with that of FSH in the present study, with levels gradually increasing during testicular growth, and dropping off once full spermiation begins. In eels, it has been demonstrated that recombinant FSH induces complete spermatogenesis by stimulating the production of spermatogenesis-inducing steroids, such as 11-KT [26]. Similarly, in European sea bass, we have shown a stimulatory effect of native FSH in the production of 11-KT in testicular tissue cultured in vitro [20]. 11-KT is the major androgen of teleost species and is considered to play an important role in the spermatogenesis of several fish species, mainly in the initiation of spermatogonial proliferation toward meiosis [36]. On the other hand, plasma LH levels increased gradually, although not significantly, as spermatogenesis progressed, with a significant elevation in late recrudescence (stage IV) that was maintained in full spermiation [30], although with concentrations consistently lower than those of FSH. These results are comparable to those observed in male rainbow trout, where maximum levels of plasma FSH appear during mid- to late testicular growth, and maximum plasma LH levels during spermiation [29]. 
In female European sea bass, the maximum plasma FSH levels were detected during vitellogenesis and post-vitellogenesis, whereas a significant decrease was observed in maturation-ovulation. Nevertheless, the pituitary FSH profile presented an opposite trend, showing low FSH levels in previtellogenesis and early vitellogenesis, high in late- and post-vitellogenesis and maturation-ovulation and again low in atresia [22]. These results indicate an active synthesis and secretion of FSH in the course of vitellogenesis, whereas during maturation-ovulation FSH secretion seems to decrease, accumulating in the pituitary. On the other hand, the plasma FSH bioactivity profile, measured in the same samples by in vitro bioassay [22], showed a tendency to achieve maximums of bioactivity in late- and post-vitellogenesis although plasma FSH concentration is maintained. Interestingly, the lowest plasma FSH levels obtained in the present study were found in maturation-ovulation coinciding with a FSH bioactivity moderately high [22]. This could be indicating an increase of the FSH potency in these stages. In fact, several studies have consistently demonstrated the occurrence of FSH isoforms with different potencies throughout the human menstrual cycle [44]. Moreover, in our case, estradiol (E2) and LH plasma levels have been previously analyzed in these same animals [30]. The maximum plasma E2 levels were observed during late- and post-vitellogenesis, coinciding with the maximums of plasma FSH levels calculated here and the maximum of plasma FSH bioactivity [22]. In females, E2 is known to stimulate the hepatic synthesis of vitellogenin, which is then progressively incorporated into the growing oocytes during oogenesis [16]. Moreover, several studies have shown that FSH stimulates the in vitro production of E2 in ovarian explants or isolated vitellogenic follicles [20, 21, 23, 28, 38]. LH plasma levels peaked at maturation-ovulation, the point when FSH reached minimum values, although at levels higher than those for LH (Rocha et al., [30] and this study, respectively). These profiles for female European sea bass GTHs are concordant with those found in salmonids. In coho salmon, Swanson [39] reported that the plasma FSH concentration increased during vitellogenesis, with the highest levels occurring during mid- to late-vitellogenesis, after which they decreased as ovulation approached. In rainbow trout, plasma FSH levels significantly increased at the onset of vitellogenesis [29], were maintained during vitellogenesis and then decreased prior to maturation [7]. On the contrary, in rainbow trout, plasma LH levels peaked at maturation-ovulation [7, 29]. Previous analysis of European sea bass pituitaries 
revealed similar FSH and LH contents (and profiles) during the reproductive cycle of females [22]; nevertheless, the data obtained in plasma suggest a different control of release to the bloodstream (Rocha et al., [30] and this study). Additionaly, pharmacokinetic studies of GTHs in European sea bass [21] and in mammals [8] have shown that FSH has a longer half-life in blood than $\mathrm{LH}$, which indicates greater clearance rates for LH. This fact would be in agreement with the lower plasma levels of LH, compared to FSH, that have been observed in males and females. Thus, our results suggest that in the case of European sea bass, high levels of FSH in the bloodstream would be necessary for long-term stimulation of gonadal growth, whereas shortterm increases in plasma LH levels might have a more specific effect during certain phases of the reproductive cycle, and therefore are likely to be cleared more quickly.

The plasma FSH levels in the group of juvenile males under a simulated natural photoperiod (control group) increased gradually until reaching a maximum value in March. On the contrary, under a regime of continuous light, the levels of plasma FSH were maintained constantly low throughout the experimental period, which probably led to a lower percentage of precocious juvenile males. The FSH content in the pituitary gland showed the same profiles (M. Carrillo, M., Felip, A., Molés, G., Yilmaz, O., Zanuy, S., unpublished data), indicating that the inhibitory effect of continuous light on FSH was at the level of synthesis, not release. These results are in agreement with previous studies in juvenile male European sea bass and adult Atlantic Cod (Gadus morhua), where continuous light produced a significant reduction of gonadotropin subunit gene expression, 11-KT plasma levels and testicular growth $[2,10,31]$. All these results suggest that continuous light reduces precocity by impairing the synthesis of FSH. This results in a decrease of 11-KT levels that very likely reduces spermatogonial proliferation towards meiosis, and consequently, testicular growth.

In conclusion, the production of recombinant FSH $\beta$ in yeast has allowed us to generate specific antibodies and develop a homologous ELISA capable of measuring FSH in both plasma and pituitary samples from European sea bass. The results of the analysis performed suggest that FSH plays an important role during active spermatogenesis and vitellogenesis, whereas LH would seem to be involved in the final reproductive events, such as spermiation, oocyte maturation and ovulation. In juvenile males, the continuous light regime significantly reduced FSH synthesis, which is probably the 
cause of the reduction of precocious puberty rates. Finally, this assay represents a valuable tool for future studies on the reproductive endocrinology of this species.

\section{Acknowledgments}

This study was supported by projects AGL2005-00796 (MEC), AQUAGENOMICS: CSD2007- 00002 (MICINN) and PROMETEO/2010/003 (GV). We wish to thank Dr. J.M. Guzman for his comments and suggestions during the development of the ELISA, Dr. J. Perez for supplying pituitary and plasma samples from sea bream, and Dr. J.P. Cañavate for pituitary samples from thicklip grey mullet and Senegalese sole.

\section{References}

[1] J. Aizen, H. Kasuto, B. Levavi-Sivan, Development of specific enzyme-linked immunosorbent assay for determining LH and FSH levels in tilapia, using recombinant gonadotropins, Gen. Comp. Endocrinol. 153 (2007) 323-332.

[2] F. F. L. Almeida, E. Andersson, C. Mittelholzer, Ø. Karlsen, G. L. Taranger, R.W. Schulz, Pituitary gonadotropin and testicular gonadotropin receptor expression in Atlantic cod (Gadus morhua L.) during the first reproductive season: Effects of photoperiod modulation, Gen. Comp. Endocrinol. 173 (2011) 111-119.

[3] J.F. Asturiano, L.A. Sorbera, J. Ramos, D.E. Kime, M. Carrillo, S. Zanuy, Hormonal regulation of the European sea bass reproductive cycle: an individualized female approach, J. Fish Biol. 56 (2000) 1155-1172.

[4] H.S. Bennett, A.D. Wyrick, S.W. Lee, J.H. McNeil, Science and art in preparing tissues embedded in plastic for light microscopy, with special reference to glycol methacrylate, glass knives and simple stains. Stain Technol. 51 (1976) 71-97.

[5] G.R. Bousfield, W.M. Perry, D.N. Ward, Gonadotropins. Chemistry and biosynthesis, in: E. Knobil, J.D. Neill (Eds), The Physiology of Reproduction, Raven Press, New York, 1994, pp. 1749-1792.

[6] I. Begtashi, L. Rodriguez, G. Moles, S. Zanuy, M. Carrillo, Long-term exposure to continuous light inhibits precocity in juvenile male European sea bass (Dicentrarchus labrax, L.). I. Morphological aspects, Aquaculture 241 (2004) 539-559.

[7] B. Breton, M. Govoroun, T. Mikolajczyk, GTH I and GTH II secretion profiles during the reproductive cycle in female rainbow trout: Relationship with pituitary responsiveness to GnRH-A stimulation, Gen. Comp. Endocrinol. 111 (1998) 38-50.

[8] R.K. Campbell, Molecular pharmacology of gonadotropins, Endocrine, 26 (2005) 291-296.

[9] M. Carrillo, S. Zanuy, F. Prat, J. Cérda, E. Mañanós, N.R. Bromage, Sea bass (Dicentrarchus labrax), in: N.R. Bromage, R.J. Roberts (Eds.), Broodstock Management and Egg and Larval Quality, Blackwell Science, London, 1995, pp. 138-168. 
[10] A. Felip, S. Zanuy, B. Muriach, J.M. Cerdá-Reverter, M. Carrillo, Reduction of sexual maturation in male Dicentrarchus labrax by continuous light both before and during gametogenesis, Aquaculture 275 (2008) 347-355.

[11] J.C. Fiddes, K. Talmadge, Structure, expression, and evolution of the genes for the human glycoprotein hormones, Recent Prog. Horm. Res. 40 (1984) 43-78.

[12] M. Govoroun, J. Chyb, B. Breton, Immunological cross-reactivity between rainbow trout GTH I and GTH II and their alpha and beta subunits: Application to the development of specific radioimmunoassays, Gen. Comp. Endocrinol. 111 (1998) 28-37.

[13] L.S. Grinna, J.F. Tschopp, Size Distribution and General Structural Features of NLinked Oligosaccharides from the Methylotrophic Yeast, Pichia pastoris, Yeast 5 (1989) 107-115.

[14] T.A. Kost, J.P. Condreay, D.L. Jarvis, Baculovirus as versatile vectors for protein expression in insect and mammalian cells, Nat. Biotechnol. 23 (2005) 567-575.

[15] B. Levavi-Sivan, J. Bogerd, E. L. Mañanós, A. Gómez, J.J. Lareyre, Perspectives on fish gonadotropins and their receptors. Gen. Comp. Endocrinol. 165 (2010) 412-437.

[16] E. Mañanós, S. Zanuy, F. Lemenn, M. Carrillo, J. Núñez, Sea bass (Dicentrarchus Labrax L) vitellogenin . I-Induction, purification and partial characterization, Comp. Biochem. Physiol. B, Biochem. Mol. Biol. 107 (1994) 205-216.

[17] E.L. Manaños, P. Swanson, J. Stubblefield, Y. Zohar, Purification of gonadotropin II from a teleost fish, the hybrid striped bass, and development of a specific enzymelinked immunosorbent assay, Gen. Comp. Endocrinol. 108 (1997) 209-222.

[18] J. Mateos, E. Mañanós, P. Swanson, M. Carrillo, S. Zanuy, Purification of luteinizing hormone (LH) in the sea bass (Dicentrarchus labrax) and development of a specific immunoassay, Cienc. Mar. 32 (2006) 271-283.

[19] T. Miura, C.I. Miura, Molecular control mechanisms of fish spermatogenesis, Fish Physiol. Biochem. 28 (2003) 181-186.

[20] G. Molés, A. Gómez, A. Rocha, M. Carrillo, S. Zanuy, Purification and characterization of follicle-stimulating hormone from pituitary glands of sea bass (Dicentrarchus labrax), Gen. Comp. Endocrinol. 158 (2008) 68-76.

[21] G. Molés, S. Zanuy, I. Muñoz, B. Crespo, I. Martínez, E. Mañanós, A. Gómez, Receptor specificity and functional comparison of recombinant sea bass (Dicentrarchus labrax) gonadotropins (Fsh and Lh) produced in different host systems, Biol. Reprod. 84 (2011a) 1171-1181.

[22] G. Molés, A. Gómez, M. Carrillo, A. Rocha, C.C. Mylonas, S. Zanuy, Determination of FSH quantity and biopotency during sex differentiation and oogenesis in European sea bass, Biol. Reprod. (2011b) (DOI:10.1095/biolreprod.111.091868).

[23] N. Montserrat, A. González, E. Mendez, F. Piferrer, J.V. Planas, Effects of follicle stimulating hormone on estradiol-17 beta production and P-450 aromatase (CYP19) activity and mRNA expression in brown trout vitellogenic ovarian follicles in vitro, Gen. Comp. Endocrinol. 137 (2004) 123-131.

[24] J.M. Navas, E. Mañanós, J. Ramos, S. Zanuy, M. Carrillo, Luteinizing hormone plasma levels in male European sea bass (Dicentrarchus labrax L.) feeding diets with different fatty acid composition, Cienc. Mar. 30 (4) (2004) 527-536.

[25] J.M. Navas, E. Mañanós, M. Thrush, J. Ramos, S. Zanuy, M. Carrillo, Y. Zohar, N. Bromage, Effect of dietary lipid composition on vitellogenin, $17 \beta$-estradiol and gonadotropin plasma levels and spawning performance in captive sea bass (Dicentrarchus 
labrax L.), Aquaculture 165 (1998) 65-79.

[26] T. Ohta, H. Miyake, C. Miura, H. Kamei, K. Aida, T. Miura, Follicle-stimulating hormone induces spermatogenesis mediated by androgen production in Japanese eel, Anguilla japonica. Biol. Reprod. 77 (2007) 970-977.

[27] J.G. Pierce, T.F. Parsons, Glycoprotein hormones: structure and function, Annu. Rev. Biochem. 50 (1981) 465-495.

[28] J.V. Planas, J. Athos, F.W. Goetz, P. Swanson, Regulation of ovarian steroidogenesis in vitro by follicle-stimulating hormone and luteinizing hormone during sexual maturation in salmonid fish, Biol. Reprod. 62 (2000) 1262-1269.

[29] F. Prat, J.P. Sumpter, C.R. Tyler, Validation of radioimmunoassays for two salmon gonadotropins (GTH I and GTH II) and their plasma concentrations throughout the reproductive cycle in male and female rainbow trout (Oncorhynchus mykiss), Biol. Reprod. 54 (1996) 1375-1382.

[30] A. Rocha, S. Zanuy, M. Carrillo, A. Gómez, Seasonal changes in gonadal expression of gonadotropin receptors, steroidogenic acute regulatory protein and steroidogenic enzymes in the European sea bass, Gen. Comp. Endocrinol. 162 (2009) 265-275.

[31] L. Rodríguez, I. Begtashi, S. Zanuy, M. Carrillo, Long-term exposure to continuous light inhibits precocity in European male sea bass (Dicentrarchus labrax, L.): hormonal aspects, Gen. Comp. Endocrinol. 140 (2005) 116-125.

[32] L. Rodríguez, M. Carrillo, L.A. Sorbera, Y. Zohar, S. Zanuy, Effects of photoperiod on pituitary levels of three forms of GnRH and reproductive hormones in the male European sea bass (Dicentrarchus labrax, L.) during testicular differentiation and first testicular recrudescence, Gen. Comp. Endocrinol. 136 (2004) 37-48.

[33] L. Rodríguez, S. Zanuy, M. Carrillo, Influence of day length on the age at first maturity and somatic growth in male sea bass (Dicentrarchus labrax, L.), Aquaculture 196 (2001) 159-175.

[34] G. Salbert, T. Bailhache, Y. Zohar, B. Breton, P. Jego, A Rapid and Sensitive Elisa for Rainbow-Trout Maturational Gonadotropin ( $\mathrm{tGtH}$ II): Validation on Biological Samples; in vivo and in vitro Responses to GnRH, Gen. Comp. Endocrinol. 78 (1990) 110-122.

[35] E.M. Santos, M. Rand-Weaver, C.R. Tyler, Follicle-stimulating hormone and its alpha and beta subunits in rainbow trout (Oncorhynchus mykiss): purification, characterization, development of specific radioimmunoassays, and their seasonal plasma and pituitary concentrations in females, Biol. Reprod. 65 (2001) 288-294.

[36] R.W. Schulz, L. R. de Franca, J. J. Lareyre, F. Legac, H. Chiarini-Garcia, R. H. Nobrega, T. Miura, Spermatogenesis in fish. Gen. Comp. Endocrinol. 165 (2010) 390-411.

[37] K. Suzuki, A. Kanamori, Y. Nagahama, H. Kawauchi, Development of salmon GTH I and GTH II radioimmunoassays, Gen. Comp. Endocrinol. 71 (1988a) 459-467.

[38] K. Suzuki, Y. Nagahama, H. Kawauchi, Steroidogenic activities of two distinct salmon gonadotropins, Gen. Comp. Endocrinol. 71 (1988b) 452-458.

[39] P. Swanson, Salmon gonadotropins: reconciling old and new ideas, in: Scott A. P., Sumpter J. P., Kime D. E., Rolfe M. S. (Eds.), Reproductive Physiology of Fish, Sheffield: FishSymp, 1991, pp. 2-7.

[40] P. Swanson, M. Bernard, M. Nozaki, K. Suzuki, H. Kawauchi, W.W. Dickhoff, Gonadotropin-I and Gonadotropin-II in Juvenile Coho Salmon, Fish Physiol. Biochem. 7 (1989) 169-176. 
[41] P. Swanson, K. Suzuki, H. Kawauchi, W.W. Dickhoff, Isolation and characterization of two coho salmon gonadotropins, GTH I and GTH II. Biol. Reprod. 44 (1991) 2938.

[42] H. Tanaka, H. Kagawa, K. Okuzawa, K. Hirose, Purification of gonadotropins (PmGTH-I and II) from red seabream (Pagrus Major) and development of a homologous radioimmunoassay for PmGTH-II, Fish Physiol. Biochem. 10 (1993) 409-418.

[43] G.L. Taranger, M. Carrillo, R.W. Schulz, P. Fontaine, S. Zanuy, A. Felip, F.A. Weltzien, S. Dufour, O. Karlsen, B. Norberg, E. Andersson, T. Hansen, Control of puberty in farmed fish. Gen. Comp. Endocrinol. 165 (2010) 483-515.

[44] T. Zariñán, A. Olivares, D. Söderlund, J.P. Méndez, A. Ulloa-Aguirre, Changes in the biological:immunological ratio of basal and GnRH-releasable FSH during the follicular, pre-ovulatory and luteal phases of the human menstrual cycle. Hum. Reprod. 16 (2001) 1611-1618. 

Capítulo 8. DISCUSIÓN GENERAL 



\section{Discusión general}

Esta sección pretende ofrecer una visión general de los resultados discutiendo los aspectos más relevantes de los trabajos presentados. Para ello, la discusión se ha desglosado en tres apartados en relación a (1) la caracterización de la FSH y producción de GTHs recombinantes, (2) desarrollo de inmunoensayos para la determinación de niveles de FSH y (3) estudio de los perfiles de GnRHs y GTHs durante la diferenciación sexual y ciclo reproductor.

\section{Caracterización de la FSH de lubina y producción de GTHs re- combinantes}

En la presente Tesis Doctoral se ha aislado y caracterizado el dímero FSH y las tres subunidades gonadotropas (GP $\alpha, F S H \beta$ y LH $\beta$ ) a partir de hipófisis de lubina. Además, mediante el uso de técnicas de expresión de proteínas recombinantes se han producido diferentes formas de FSH y LH, y se han estudiado algunas de sus propiedades bioquímicas y funcionales.

La purificación de GTHs se realizó a partir de 1400 hipófisis mediante extracción alcohólica de glicoproteínas, seguida de técnicas cromatográficas de intercambio iónico y fase reversa bajo condiciones ligeramente básicas. La metodología empleada fue idónea para aislar FSH, pero no LH, pues se obtuvo una gran cantidad de sus subunidades (GP $\alpha$ y LH $\beta$ ) pero escaso dímero. Al igual que en otras especies de peces (Okada et al., 1994; Suzuki et al., 1988b; Weltzien et al., 2003), parece que en la lubina la LH es menos estable que la FSH, ya que durante el proceso de purificación tuvo lugar una considerable disociación de sus subunidades. En peces, los análisis de las secuencias de aminoácidos de las subunidades FSH $\beta$ muestran que estas son más variables que las de $\mathrm{LH} \beta$ en regiones importantes para la formación del heterodímero e interacciones con el receptor. Esta variación estructural de las FSH $\beta$ podría dar lugar diferencias inter-especificas en la naturaleza de 
las interacciones con el receptor y posiblemente en la estabilidad del heterodímero (Swanson et al., 2003).

La identidad y el grado de pureza de la FSH y de las subunidades gonadotropas purificadas se confirmó por secuenciación N-terminal de aminoácidos y por Western blot. Los resultados de la secuenciación se compararon con las secuencias de aminoácidos deducidas a partir de los ADNc (Mateos et al., 2003), confirmando que la fracción $1 B 10$ contenía una proteína altamente pura, compuesta por las subunidades GP $\alpha$ y FSH $\beta$, mientras que las fracciones $1 \mathrm{C} 11,4 \mathrm{C} 2$ y 7C6 correspondían a las subunidades libres GP $\alpha$, FSH $\beta$ y LH $\beta$, respectivamente (ver Fig. 5, pag. 107). Los análisis por Western blot, usando anticuerpos disponibles contra la GP $\alpha$ y LH $\beta$ de lubina (Mateos et al., 2006) y un péptido sintético de la FSH $\beta$ del fúndulo (Fundulus heteroclitus) cedido por el Dr. Akio Shimizu (Shimizu y Yamashita, 2002), ratificaron que se trataba de las subunidades gonadotropas de lubina (ver Fig. 4, pag. 106). Además, la secuenciación N-terminal mostró que, cuando se comparaba la secuencia de la FSH $\beta$ purificada $(1 \mathrm{~B} 10$ y $4 \mathrm{C} 2)$ con la secuencia de otras especies o con la deducida a partir del propio ADNc, le faltaban los tres primeros aminoácidos (G-Q-G). Esta heterogeneidad N-terminal también se ha observado en otras especies como el atun (Thunnus obesus) o el fletán (Hippoglossus hippoglossus) y sugiere que esta porción de FSH $\beta$ podría ser más susceptible a degradación proteolítica durante el proceso de purificación que la de LH $\beta$ (Okada et al., 1994; Weltzien et al., 2003). En este estudio solo se identificó una forma de FSH $\beta$ a la que le faltaban los tres primeros residuos del extremo $\mathrm{N}$-terminal, lo que hace difícil saber si esta secuencia corresponde a la verdadera región $\mathrm{N}$-terminal de la FSH madura o si es más bien resultado de un proceso de degradación durante la purificación.

Los pesos moleculares de la FSH $(28.5 \mathrm{KDa})$ y de las tres subunidades gonadotropas (GPa: 12.6 KDa, FSH $\beta$ : 13.6 KDa, LHß: 15.3 KDa), estimados por espectrometría de masas, son más pequeños que los calculados en otras especies de teleósteos. De todas formas, cabe decir que existe una gran variabilidad en los cálculos de los pesos moleculares de las GTHs de peces descritas hasta el momento, encontrando subunidades GP $\alpha$, FSH $\beta$ y LH $\beta$ en el rango de 15 a $27 \mathrm{KDa}$ y dímeros FSHs desde 32 a $50 \mathrm{KDa}$ (ver Tabla 2, pag. 37). Según algunos autores (Hearn y Gomme, 2000) los oligosacáridos de las 
GTHs pueden contribuir entre un 20 y $40 \%$ del peso total de la molécula. Para confirmar la presencia de oligosacáridos en la FSH purificada en este estudio, se realizó un tratamiento con una $N$-glicosidasa (PNGase F) (ver Fig. 4, pag. 106). Este redujo considerablemente el tamaño de las subunidades GP $\alpha$ y FSH $\beta$, lo que indicaba que ambas estaban $N$-glicosiladas y corroboraba las predicciones de sitios potenciales de $N$-glicosilación realizadas a partir de los ADNc (Mateos et al., 2003). En general, según las secuencias de aminoácidos, la contribución del esqueleto polipeptídico al peso molecular de las GTHs es similar entre las diferentes especies de teleósteos. Por ello, la variabilidad observada entre los pesos moleculares podría atribuirse a diferencias en la porción glicosídica de las subunidades o a diferencias asociadas al método de medida.

La especificidad y actividad biológica de la FSH purificada se evaluó por su capacidad de estimular los receptores homólogos (FSHR y LHR) expresados en una línea celular heteróloga (HEK 293) (ver Fig. 6, pag. 108). En mamíferos, las barreras de especificidad entre cada pareja receptor-gonadotrofina están bien definidas y son tales que bajo condiciones fisiológicas no hay señalización cruzada (Braun et al., 1991; Moyle et al., 1994). Por el contrario, en peces hay evidencias que indican que la especificidad entre las GTHs y sus receptores es menos obvia (Bogerd et al., 2005; Levavi-Sivan et al., 2010). En este estudio, se demostró que la FSH purificada era biológicamente activa y altamente especifica ya que activó FSHR de manera dosis dependiente pero no activó LHR incluso a dosis elevadas (200 ng/ml). Además de la activación de receptores, se estudió la actividad esteroidogénica de la FSH en cultivos in vitro de tejido gonadal y se demostró que estimulaba significativamente la producción de T y 11-KT en testículos y de E2 en ovarios de lubinas adultas de manera dosis y tiempo dependiente (ver Fig. 7-9, pag. 109-111). Esta estimulación fue mayor en machos en recrudescencia testicular (octubre) y en hembras vitelogénicas (octubre y noviembre). La T y 11KT son los principales andrógenos producidos por los peces machos (Borg, 1994) y son esenciales para que tenga lugar la espermatogénesis (Fostier et al., 1983; Schulz y Miura, 2002). Además se ha demostrado que la 11-KT, aparentemente regulada por la FSH, es un factor endocrino clave del inicio de la proliferación espermatogonial hacia la meiosis (Schulz et al., 2010). Por otro lado, numerosos trabajos han demostrado que la vitelogénesis está regulada por el E2 (Nagahama, 1994) y se ha descrito que en folículos vite- 
logénicos de trucha (Salmo trutta), la FSH estimula la expresión y actividad de la enzima P-450 aromatasa (CYP19A1) que cataliza la conversión de T a E2, jugando un papel fundamental en la regulación de la producción de E2 en ovarios de salmónidos (Montserrat et al., 2004). En la lubina, los niveles plasmáticos de 11-KT y T incrementan durante el periodo de espermatogénesis (octubre-enero) (Prat et al., 1990; Rocha et al., 2009; Rodriguez et al., 2004) y los de E2 aumentan en paralelo con los de vitelogenina y el crecimiento folicular (Asturiano et al., 2000; Asturiano et al., 2002). En conjunto todos estos datos apoyan la idea de que en la lubina, la FSH estimula la proliferación espermatogonial en machos y la vitelogénesis en hembras mediante la síntesis de esteroides sexuales.

La purificación de la FSH de lubina ha permitido estudiar algunos aspectos bioquímicos y fisiológicos de esta hormona. Sin embargo, para el desarrollo de nuevas investigaciones en el área de endocrinología reproductiva de peces, y en particular de la lubina, es esencial disponer de ambas GTHs de forma continuada. La purificación de GTHs nativas es un proceso muy exigente en términos de tiempo y dinero, para el cual se requiere una gran cantidad de hipófisis que a menudo limita su disponibilidad. Por ello, la producción de formas recombinantes de GTHs representa una excelente alternativa a las hormonas nativas ya que pueden ser producidas continuamente, asegurando su disponibilidad y evitando contaminaciones cruzadas con otras glicoproteínas hipofisarias.

En el transcurso de la presente Tesis Doctoral, se han producido diferentes formas recombinantes de FSH y LH de lubina usando dos sistemas de expresión, células de insecto ( $\mathrm{Sf9}$ ) y células de mamífero (CHO). En el primer caso se infectaron células Sf9 con baculovirus modificados que contenían los genes de las subunidades gonadotropas de lubina. Tras la infección, los virus se apoderaron de la maquinaria celular y expresaron sus genes de forma abundante, entre ellos los de las subunidades gonadotropas. En el segundo caso, la expresión de las GTHs se realizo mediante transfecciones estables de células $\mathrm{CHO}$. Después de transfectar con plásmidos portadores de los genes de las subunidades gonadotropas, se seleccionaron aquellos clones de células $\mathrm{CHO}$ que habían incorporado el casete de expresión en el genoma de la célula y producían mayores niveles de GTHs.

Estos dos sistemas han servido para expresar y secretar eficientemen- 
te formas diméricas (subunidades unidas por enlaces no covalentes: Sf9FSH, Sf9-LH y CHO-FSH) y de cadena única (fusión de ambas subunidades: CHO-scFSH y CHO-scLH). Los niveles de producción fueron comparables a los descritos por otros autores en la producción de GTHs de peces (LevaviSivan et al., 2010), y considerablemente mas altos con el sistema baculovirus usando células Sf9 que con transfecciones estables de células $\mathrm{CHO}$. Cuando se analizó la biopotencia de las formas recombinantes de $\mathrm{FSH}\left(\mathrm{EC}_{50} \mathrm{y}\right.$ ratios de determinación Biológica : Inmunológica, (B:I)), se vio que Sf9-FSH era más bioactiva que $\mathrm{CHO}-\mathrm{FSH}$ pero menos que $\mathrm{CHO}$-scFSH. Análisis funcionales realizados en mamíferos han demostrado que las GTHs presentan bioactividades diferentes en función del tipo de glicosilación presente en cada isoforma (Ambao et al., 2009; Olivares et al., 2009; Zambrano et al., 1996). Concretamente, se ha demostrado que isoformas de FSH y LH con menos contenido en acido siálico exhiben mayores ratios B:I y son más potentes que sus homologas más acidas. Por tanto, las diferencias en bioactividad observadas con las FSHs recombinantes de lubina podrían estar relacionadas con el tipo y grado de glicosilación que reciben según el sistema de expresión empleado. En este sentido, hay que decir que las células de insecto carecen de la maquinaria enzimática necesaria para añadir oligosacáridos terminales de galactosa y/o acido siálico y producen un tipo glicosilación muy sencilla del tipo "paucimanosa", constituida principalmente por una estructura básica de residuos de manosa. Por el contrario, las células de mamíferos son capaces de añadir oligosacáridos complejos sializados (Kost et al., 2005). Todos estos datos apoyan nuestros resultados, ya que la Sf9FSH, no sializada, fue más bioactiva que la CHO-FSH. En el caso concreto de la forma de cadena única, $\mathrm{CHO}$-scFSH, su mayor potencia podría estar influenciada o relacionada con otros aspectos como el hecho de ser una proteína de fusión o por la presencia del péptido carboxi-terminal (CTP) de la CG humana, el cual se sabe que incrementa la estabilidad extracelular (BenMenahem and Boime, 1996; Fares et al., 1992).

Paralelamente a la producción de dímeros recombinantes también se expresaron de forma individual las subunidades FSH $\beta$ y LH $\beta$ en células Sf9. De las dos subunidades solo Sf9-LH $\beta$ se secretó eficientemente al medio de cultivo, mientras que Sf9-FSH $\beta$ quedaba retenida en el interior de las células infectadas (ver Fig. 2, pag. 138). Situaciones similares se han descrito en la producción de otras subunidades gonadotropas recombinantes. Por ejem- 
plo, al contrario que GP $\alpha$ y hCG $\beta$, las subunidades FSH $\beta$ y LH $\beta$ humanas, expresadas en células de mamífero ( $\mathrm{C}-127$ y $\mathrm{CHO})$, fueron secretadas deficientemente y degradadas lentamente en el interior de las células (Corless et al., 1987a; Corless et al., 1987b; Keene et al., 1989). En células de insecto (Sf21), la GPo bovina se encontró en el medio de cultivo a niveles 10 veces superiores a los de la FSH $\beta$ (van de Wiel et al., 1998) y la GPo de pez gato (Clarias gariepinus) fue la única de las tres subunidades gonadotropas producida en abundancia como subunidad libre en células de Drosophila (S2) (Zmora et al., 2007). La razón de este comportamiento no está clara, pero se sabe que proteínas que no alcanzan su conformación nativa en el retículo endoplasmático rugoso, subunidades huérfanas y algunas proteínas expresadas de forma heteróloga pueden ser retenidas selectivamente y más tarde devueltas al citosol donde son degradadas (Helenius y Aebi, 2001; Kleizen y Braakman, 2004). Sin embargo, generalmente, la coexpresión de ambas subunidades $(\alpha$ y $\beta)$ lleva a un ensamblaje correcto y a una secreción eficiente (Keene et al., 1989; van de Wiel et al., 1998; Zmora et al., 2007).

$\mathrm{Al}$ igual que se hizo con la FSH nativa, también se evaluó la bioactividad y especificidad de las GTHs recombinantes por su capacidad para activar los receptores homólogos (FSHR y LHR) y por su actividad esteroidogénica en cultivos in vitro de gónadas de lubina. Todas las GTHs recombinantes producidas activaron específicamente a sus respectivos receptores de manera dosis dependiente, sin mostrar actividad cruzada en un amplio rango de concentraciones (ver Fig. 3, pag. 140). Además, ni la presencia del CTP, incluido en las recombinantes de cadena única, ni la cola de histidinas de los dímeros FSH, influyeron en dicha especificidad de unión al receptor. Como se comento anteriormente, al contrario de lo que ocurre en mamíferos, donde las interacciones ligando-receptor son muy específicas, en la mayoría de especies de peces analizadas se han observado interacciones promiscuas, principalmente con FSHR-LH (Levavi-Sivan et al., 2010). Las bases estructurales y/o significado fisiológico de esta promiscuidad todavía no están claros. Para ampliar nuestro conocimiento acerca de la especificidad de ligandos por parte de los receptores de lubina, se estudió su capacidad de unión a GTHs heterólogas humanas (hFSH y hCG). Curiosamente, el LHR se activó con hCG y hFSH casi con igual potencia, mientras que el FSHR apenas respondió a la hFSH (ver Fig. 3, pag. 140). Este comportamiento de los receptores de lubina con las GTHs humanas fue similar al observado an- 
teriormente por Rocha et al. (2007) con las GTHs bovinas. Esta promiscuidad con las GTHs de mamíferos también se ha observado para los LHRs de pez cebra (Danio rerio), salmón amago (Oncorhynchus rhodurus) y pez gato (Clarias gariepinus) (Kwok et al., 2005; Oba et al., 1999a; Vischer y Bogerd, 2003). De acuerdo con lo sugerido por Rocha et al. (2007), en el caso de la lubina, la respuesta promiscua del LHR a las FSHs de mamíferos (hFSH y bFSH) pero no a la FSH de lubina, podría deberse a una mayor similitud entre la estructura tridimensional de FSHs de mamíferos y la LH de lubina que con la propia FSH. Todos estos datos, junto con la débil respuesta de FSHR a la hFSH y al hecho de que en la lubina están ausentes muchos residuos considerados importantes para la unión hFSH/hFSHR de humanos (Fan y Hendrickson, 2005; Rocha et al., 2007), recomiendan cierta precaución a la hora de usar modelos de mamíferos para explicar las interacciones FSHreceptor de peces.

La actividad biológica de las GTHs recombinantes también se analizó por su capacidad esteroidogénica en cultivos in vitro de gónadas de lubina. En este caso, todas las GTHs recombinantes fueron capaces de inducir la producción de esteroides en ovario y testículo (ver Fig. 5 y 6, pag. 143-144). Sf9FSH y Sf9-LH tuvieron un efecto similar en la estimulación de la producción de E2 en el ovario, mientras que en el testículo Sf9-LH fue más potente en estimular la producción de 11-KT. Otros estudios in vitro con GTHs nativas y recombinantes de otras especies de peces también han demostrado su capacidad esteroidogénica aunque con diferentes potencias. En la dorada japonesa (Pagrus major), como en la lubina, la LH fue más efectiva que la FSH en estimular la liberación de 11-KT (Kagawa et al., 1998b). En salmón coho (Oncorhynchus kisutch), la potencia de la LH para estimular la producción de 11-KT supero a la de FSH a medida que avanzaba la espermatogénesis (Planas y Swanson, 1995). Sin embargo, en pez cebra (Danio rerio) y en azul o bagre del canal (Ictalurus punctatus), la FSH recombinante fue más efectiva que la LH en estimular la liberación de andrógenos (García-López et al., 2010; Zmora et al., 2007). Además, en testículos de pez gato, la cantidad de FSH necesaria para obtener una liberación significativa de esteroides fue menor que la de LH (García-López et al., 2009). Estas diferencias en la respuesta esteroidogénica podrían estar más relacionadas con el estado de desarrollo gonadal y por lo tanto con la presencia del receptor correspondiente (FSHR y/o LHR), que con la propia capacidad esteroidogénica de cada una de ellas. En este sentido, en el pez cebra se ha sugerido que la mayor potencia 
observada de la FSH podría deberse a mayores niveles de expresión de FSHR que de LHR (García-López et al., 2010). En nuestro estudio, los cultivos de testículo estaban en espermatogénesis tardía y en este estado gonadal no se han detectado diferencias en la expresión de los receptores de lubina (Rocha et al., 2009). Así, aunque se ha demostrado que en los teleósteos ambas GTHs son esteroidogénicas, serán necesarios más estudios para dilucidar totalmente el papel de cada hormona en cada etapa de la espermatogénesis.

Algunos estudios en peces sugieren que las GTHs recombinantes producidas en células de insecto podrían ser eliminadas rápidamente de la circulación sanguínea (Kazeto et al., 2008; Kobayashi et al., 2010a), aunque no ha sido demostrado ni cuantificado. Por ello, en nuestro caso, antes de realizar experimentos in vivo decidimos estudiar la estabilidad en sangre y conocer la farmacocinética de las GTHs recombinantes producidas. Los análisis mostraron que las $\mathrm{CHO}$-scGTHs tenían mayor estabilidad en plasma que las Sf9-GTHs (ver Fig. 7, pag. 147). Una vez más, la presencia o ausencia de ciertos oligosacáridos en su molécula podría estar detrás de dicha estabilidad. Numerosos estudios con GTHs de mamíferos han demostrado que el contenido de ciertos oligosacáridos, mas concretamente de acido siálico, a parte de influir en la bioactividad, pueden ser determinantes en la velocidad con que las glicoproteínas se eliminan de la circulación sanguínea. Así, por ejemplo, a mayor contenido de acido siálico menor potencia pero mayor vida media (Ambao et al., 2009; Olivares et al., 2009; Ulloa-Aguirre et al., 2001). Como se mencionó anteriormente, al contrario que a las células $\mathrm{CHO}$, a las células Sf9 les falta la maquinaria enzimática necesaria para añadir estos oligosacáridos. Además, en el caso de las CHO-scGTHs, la fusión de las dos subunidades y la presencia de oligosacáridos unidos mediante enlaces O-glicosídicos al CTP, podrían contribuir a prolongar su vida media en circulación (Ben-Menahem y Boime, 1996; Fares et al., 1992; Klein et al., 2003). En ambos sistemas de expresión (CHO y Sf9), las FSHs producidas presentaron mayor estabilidad que las LHs. Dicha particularidad, junto con otros datos que veremos mas adelante (apartado 3 de esta discusión), nos lleva a pensar en una posible relación entre la estabilidad y el papel fisiológico de estas hormonas.

En general, aunque los resultados obtenidos aquí y en otras especies indican que GTHs heterólogas pueden unirse a los receptores de peces, puede 
que sus efectos fisiológicos no reproduzcan exactamente los de las hormonas homologas. Por lo tanto, debido a las dificultades para aislar hormonas nativas, la producción de GTHs recombinantes es una excelente alternativa para disponer de estas hormonas de forma continuada y facilitar la realización de estudios relacionados con la fisiología de las mismas. En este estudio, hemos producido FSHs y LHs de lubina similares a las hormonas nativas que pueden ser usadas en estudios futuros con esta especie. Los dos sistemas de expresión empleados fueron eficaces en la producción de GTHs recombinantes, sin embargo cada sistema ofreció unas ventajas diferentes que hay que tener en cuenta según los objetivos que se pretendan conseguir. En términos de producción, el sistema baculovirus con células Sf9 fue más eficiente que el sistema de células $\mathrm{CHO}$. El primero resulto particularmente útil para producir grandes cantidades de GTHs y sus subunidades, necesarias, por ejemplo, para el desarrollo de diferentes ensayos de detección y determinación (producción de anticuerpos y estándares). Sin embargo, los datos obtenidos in vivo mostraron que las GTHs producidas en células de insecto tenían eliminación plasmática más rapida que las producidas en células de mamífero. Así, debido a su mayor estabilidad en sangre, las recombinantes CHO-GTHs y en particular las de cadena única parecen ser mejores candidatas para realizar futuros estudios in vivo.

Los trabajos realizados en esta sección han proporcionado las bases y herramientas necesarias para el desarrollo de nuevas metodologías importantes en el estudio de la reproducción de la lubina.

\section{Desarrollo de ensayos para la determinación de niveles de FSH}

En la presente Tesis Doctoral se han desarrollado diferentes ensayos homólogos (Bioensayo, Dot-blot y ELISA) para determinar niveles de FSH en hipófisis y plasma, imprescindibles para la consecución de los objetivos planteados en la misma.

Básicamente, los métodos para cuantificar moléculas biológicamente activas como las GTHs se agrupan en dos categorías, aquellos que estiman una cantidad o numero de moléculas mediante la unión especifica de anticuerpos (inmunoensayos) y aquellos que determinan una respuesta biológica (bioensayos). Las estimaciones inmunológicas de una hormona, suelen ser altamente precisas, sin embargo no reflejan necesariamente la señal perci- 
bida por su correspondiente receptor y por consiguiente su efecto biológico (Christin-Maitre y Bouchard, 1996). Por ello, los bioensayos in vitro constituyen una excelente aproximación para determinar aspectos funcionales de las GTHs. En esta Tesis Doctoral se han desarrollado inmunoensayos específicos y un bioensayo que han permitido evaluar conjuntamente tanto cantidad, como bioactividad de la FSH en momentos críticos del ciclo reproductor de la lubina.

Hasta la fecha solo se han logrado desarrollar inmunoensayos homólogos de FSH en tres especies de teleósteos con desarrollo ovárico síncrono, salmón chum (Oncorhynchus keta), salmón coho (Oncorhynchus kisutch) y trucha arcoiris (Oncorhynchus mykiss), y una con desarrollo asíncrono, tilapia (Oreochromis niloticus) (Aizen et al., 2007; Govoroun et al., 1998; Suzuki et al., 1988a; Swanson et al., 1989; Swanson et al., 1991). Tradicionalmente los inmunoensayos desarrollados para estudiar los niveles de GTHs de peces han sido radioinmunoensayos (RIAs) o ensayos de inmunoabsorción ligados a enzimas (ELISAs), ambos basados en GTHs nativas y sus respectivos anticuerpos específicos. En nuestro caso usamos FSH y FSH $\beta$ recombinantes producidas en diferentes sistemas de expresión. Inicialmente, mediante el sistema de expresión baculovirus, se produjo gran cantidad de FSH $\beta$ que se utilizó para generar anticuerpos policlonales específicos. Estos mostraron una fuerte reacción específica bajo condiciones reductoras pero muy débil en condiciones nativas, lo cual condicionó el tipo de inmunoensayo a desarrollar. No hemos encontrado una razón clara que explique la baja afinidad de estos anticuerpos por la hormona en condiciones nativas. No obstante, todo parece indicar que la desnaturalización de la FSH $\beta$ durante el segundo paso de purificación pudo haber sido crucial en la generación de unos anticuerpos que reconocían principalmente epítopos internos de la subunidad. Esta circunstancia explicaría las diferencias observadas en la reactividad del antígeno bajo condiciones reductoras o nativas. Debido a la débil reacción de los anticuerpos en condiciones nativas no fue posible desarrollar un ELISA, en su lugar se puso apunto un inmunoensayo tipo "Dot-blot" capaz de usar muestras desnaturalizadas. Este ensayo no presento reacción cruzada con la LH de lubina y mostró bajos CV intra- e interensayo, comparables a los descritos para otros inmunoensayos de FSH en peces (Aizen et al., 2007; Govoroun et al., 1998; Suzuki et al., 1988a). La sensibilidad del ensayo (162.8 $\mathrm{ng} / \mathrm{ml}$ ) fue adecuada para el análisis de niveles hipofisarios de FSH, sin em- 
bargo no fue suficiente para determinar niveles en plasma, ya que estos estuvieron siempre por debajo del limite de detección.

La necesidad de disponer de un inmunoensayo capaz de medir FSH en plasma, impulsó la producción de un nuevo lote de FSH $\beta$ recombinante para generar nuevos anticuerpos más adecuados. En esta ocasión se uso un sistema de expresión de proteínas recombinantes en levadura (Pichia pastoris). Este sistema ha demostrado ser muy eficaz en la producción y secreción de subunidades recombinantes libres (Levavi-Sivan et al., 2010) y se caracteriza por su bajo coste y fácil manejo. Los niveles de producción de FSH $\beta$ fueron ligeramente inferiores a los obtenidos previamente en el sistema baculovirus usando células Sf9. Sin embargo, al contrario de este último, la FSH $\beta$ producida en levadura se secretó eficientemente al medio de cultivo y pudo ser fácilmente purificada, conservando su conformación nativa. El tamaño de la FSH $\beta$ producida fue levemente superior al obtenido con el sistema baculovirus (ver Fig. 3, pag. 199). No obstante, debido a que la secuencia utilizada es la misma, estas diferencias se pueden atribuir al grado de glicosilación recibido, ya que se sabe que Pichia pastoris realiza una glicosilación del tipo "alto contenido en manosa" (Grinna y Tschopp, 1989) mientras que las células de insecto del tipo "paucimanosa" (Kost et al., 2005). De nuevo, la FSH $\beta$ producida se usó para generar anticuerpos policlonales y esta vez reconocieron específicamente la $\mathrm{FSH} \beta$, tanto en su forma desnaturalizada, como en su forma nativa. Los nuevos anticuerpos generados fueron aptos para desarrollar un inmunoensayo tipo ELISA que mostró características óptimas de precisión, especificidad y sensibilidad, comparables a las descritas para otros inmunoensayos de GTHs de peces (ver Tabla 5, pag. 54). Además, la alta precisión (CV intra- e inter-ensayo < 5\% y 9\%, respectivamente), la ausencia de reacción cruzada con LH y su mayor sensibilidad $(0.50 \mathrm{ng} / \mathrm{ml})$, permitió validar el ELISA tanto para muestras de hipófisis como de plasma. Por otro lado, el ELISA fue altamente específico para la FSH de lubina ya que se observó un paralelismo escaso o nulo con diluciones seriadas de muestras de otras especies (ver Fig. 5, pag. 201).

Por último, se desarrolló un bioensayo in vitro usando un clon estable de la línea celular HEK 293 que expresa el FSHR de lubina y el gen de la luciferasa (Rocha et al., 2007). Este ensayo mostró una activación del FSHR dosis-dependiente y fue capaz de medir niveles de bioactividad de FSH con un alto grado de sensibilidad $(0.104 \mathrm{ng} / \mathrm{ml})$ y especificidad, en concordancia 
con otros bioensayos de FSH descritos en mamíferos (Christin-Maitre et al., 2000). Sin embargo, hay que mencionar que las concentraciones calculadas por los inmunoensayos siempre fueron mayores que con el bioensayo. Una posible explicación a este hecho podría estar relacionada con la potencia de la FSH usada como estándar en el bioensayo, ya que en el caso de un estándar mas potente que las muestras daría lugar a niveles más bajos al extrapolar una concentración. Por otro lado, hay que tener en cuenta que los inmunoensayos no distinguen entre dímeros (FSH) y monómeros (FSH $\beta$ ), mientras que en el bioensayo solo los dímeros (FSH) son bioactivos y por lo tanto cuantificados. En peces, los sistemas de transactivación de los receptores de GTHs se han usado frecuentemente para investigar la especificidad de las interacciones hormona/receptor (Levavi-Sivan et al., 2010). Sin embargo, nuestro bioensayo para FSH es el primero desarrollado y validado en peces que permite medir niveles de actividad FSH en plasma e hipófisis.

En conjunto, los diferentes métodos desarrollados han permitido determinar, por primera vez en la lubina, niveles plasmáticos e hipofisarios de FSH en diversos experimentos y han sentado las bases metodológicas precisas para abordar estudios posteriores.

\section{Estudio de perfiles de GnRHs y GTHs durante la diferenciación sexual y ciclo reproductor}

La disponibilidad de los ensayos descritos en el apartado anterior permitió analizar los niveles de FSH en hipófisis y en plasma durante la diferenciación sexual, la prepubertad y el ciclo reproductor de la lubina. Además, durante el proceso de diferenciación sexual, se estudiaron los perfiles de expresión génica de las GnRHs, GnRHR y GTHs así como los correspondientes niveles hormonales.

Algunos estudios en mamíferos han demostrado que existe una relativa abundancia de isoformas de GTHs que difieren en su composición glicosídica y cuya presencia esta estrechamente relacionada con el estado funcional de la gónada (Ambao et al., 2009; Christin-Maitre et al., 1996; UlloaAguirre et al., 2003). Estas isoformas muestran diferencias en su estabilidad y biopotencia, provocando un rango de respuestas biológicas tanto in vitro como in vivo (Ulloa-Aguirre et al., 2003). Partiendo del supuesto de que la 
inmunoreactividad es una medida de la cantidad de FSH y que bioactividad proporciona información relativa a la capacidad de provocar una respuesta biológica, la relación de las determinaciones Biológicas/Inmunológicas (B:I) debería proporcionar una evaluación de la calidad media de las moléculas individuales de FSH en una muestra biológica, en un momento dado. Así, el desarrollo y uso combinado de un bioensayo y un inmunoensayo para FSH en el transcurso de la presente Tesis Doctoral, ha permitido evaluar la actividad biológica de cantidades definidas de FSH de acuerdo al estado biológico del animal.

Para estudiar el control endocrino de la diferenciación sexual se crearon dos poblaciones de machos y hembras de lubina mediante selección de tamaños, en base a la existencia de una fuerte relación entre el crecimiento y el fenotipo sexual (Blázquez et al., 1999; Saillant et al., 2003). Los primeros signos histológicos de diferenciación gonadal se observaron alrededor de los 150 días después de la eclosión (dph) en hembras y 200 dph en machos, mientras que a los 250 dph las gónadas estaban completamente diferenciadas en ambos sexos (Papadaki et al., 2005). Los análisis de expresión génica mostraron que en ambas poblaciones había un pico de expresión cerebral de sbGnRH (GnRH-1) y sGnRH (GnRH-3) que coincidía con el inicio de la diferenciación sexual (ver Fig. 1, pag. 76). En el mismo periodo, se detectaron niveles máximos de expresión de $\mathrm{FSH} \beta$, que se mantuvieron altos hasta el final del proceso y fueron claramente superiores a los de LH $\beta$ (ver Fig. 3, pag. 79). Además, en ambos sexos se observó una fuerte correlación entre la expresión cerebral de sbGnRH y el receptor hipofisario dlGnRH-R-2A (actualmente denominado dlGnRHRII-1a), y de este último con la expresión hipofisaria de FSH $\beta$ y LH $\beta$, sugiriendo su participación en la diferenciación sexual. Al mismo tiempo, los análisis neurohormonales mostraron un contenido alto de GnRHs en la hipófisis antes o al inicio de la diferenciación sexual, siendo el de sbGnRH mayor que el de sGnRH, y en ambos casos mayor en hembras (ver Fig. 2, pag. 77). Estos resultados concuerdan con el hecho de que sbGnRH es considerada la principal forma hipofisiotrófica implicada en la secreción de GTHs en la lubina (González-Martínez et al., 2002a; González-Martínez et al., 2002b). En cuanto a las GTHs, los análisis de FSH mostraron que había una fuerte bioactividad de FSH en plasma al inicio de la diferenciación y una acumulación progresiva de FSH en hipófisis (ver Fig. 5, pag. 173). Sin embargo, como ya insinuaba la actividad transcripcional 
de LH $\beta$, los niveles plasmáticos de LH fueron muy bajos durante de la diferenciación sexual, mostrando únicamente una elevación discreta a los 250 dph, cuando las gónadas ya estaban completamente diferenciadas (ver Fig. 4, pag. 81). Todos estos resultados refuerzan la hipótesis de que la FSH tiene un papel importante durante la diferenciación sexual y que su secreción esta regulada principalmente por sbGnRH y en menor medida por sGnRH a través de la activación del dlGnRH-R-2A. Por otra parte, cabe señalar que los análisis inmunohistoquímicos realizados en hipófisis de lubina adultas (ver Fig. 7, pag. 176) revelaron que, como en otras especies de teleósteos (Calman et al., 2001; García-Ayala et al., 1998; Kagawa et al., 1998a; Miranda et al., 2001; Nozaki et al., 1990), la FSH y LH se sintetizan en diferentes poblaciones de células de la adenohipófisis. En este sentido, en estudios previos con trucha arcoiris (Oncorhynchus mykiss), platy (Xiphophorus maculatus) y acará (Cichlasoma dimerus) se ha descrito que las células gonadotropas de FSH aparecen antes del inicio de la diferenciación sexual, mientras que las de LH surgen varios días después de que haya empezado el proceso o justo al finalizar (Pandolfi et al., 2006; Feist y Schreck, 1996; Magliulo-Cepriano et al., 1994; Saga et al., 1993). En conjunto, todos estos datos apoyan una posible acción de la FSH durante la diferenciación gonadal de peces teleósteos. Además cabe destacar que en la lubina los niveles plasmáticos e hipofisarios de FSH y los ratios B:I calculados en hipófisis, fueron más altos en hembras que en machos, lo que sugiere un dimorfismo sexual en la síntesis y potencia de la FSH durante la diferenciación sexual. Este hecho esta además apoyado por los mayores niveles hipofisarios de sbGnRH y sGnRH detectados en hembras. Al mismo tiempo, en estudios paralelos con las mismas poblaciones y en el mismo periodo (Blázquez y Piferrer, 2004; Piferrer et al., 2005), se observó que en las hembras los niveles de expresión de la enzima citocromo P450 aromatasa en gónada (CYP19A1) y en cerebro (CYP19A2) eran mayores que en los machos, sugiriendo que los altos niveles de FSH vistos en este estudio podrían estar involucrados en el control de su expresión.

Transcurrido el periodo de diferenciación sexual, las gónadas diferenciadas (ovarios o testículos) permanecen inmaduras (1 o 2 años) hasta la llegada de la pubertad. Muy a menudo bajo condiciones de cultivo intensivo aparecen machos precoces que adelantan la primera maduración sexual. La pubertad prematura en la lubina es un gran problema que causa importantes perdidas al sector acuícola ya que los peces precoces experimentan un re- 
ducción del crecimiento y son más vulnerables a enfermedades (Taranger et al., 2010). Con el fin de evitar el inicio prematuro de la pubertad, en nuestro grupo se han venido realizando en los últimos años numerosas experiencias (Begtashi et al., 2004; Felip et al., 2008; Rodríguez et al., 2005; Rodríguez et al., 2001) que han demostrado la eficacia de determinados tratamientos de luz para reducir el porcentaje de machos precoces. Sin embargo, se necesitan más estudios para comprender los mecanismos subyacentes de esta inhibición, en particular en lo que respecta a las GTHs. En el transcurso de la presente Tesis Doctoral se analizaron los perfiles de FSH en machos de lubina prepúberes sometidos a diferentes condiciones de fotoperiodo (durante 10 meses) para averiguar como afecta la luz en la reducción de la precocidad (ver Fig. 7, pag. 203). En machos juveniles inmaduros sometidos a fotoperiodo natural, los niveles plasmáticos de FSH aumentaron gradualmente, alcanzando máximos en Marzo, al final del experimento. En ese momento el porcentaje de machos espermiantes (precoces) fue del 65\%. Sin embargo, el tratamiento de luz continua (24h/día) mantuvo los niveles de FSH invariables a lo largo del periodo experimental, mostrando una reducción significativa respecto el grupo control, tanto de los niveles de FSH en Marzo, como del número de machos precoces que no supero el 10\%. Además, el análisis del contenido de FSH en hipófisis (datos no mostrados) presento los mismos perfiles, indicando que el efecto inhibitorio de la luz continua sobre la FSH era a nivel de síntesis y no de liberación. Estos resultados apoyan estudios previos con machos juveniles de lubina donde se vio que la luz continua producía una reducción significativa de la expresión génica de las subunidades gonadotropas, de los niveles plasmáticos de 11-KT y del crecimiento testicular (Felip et al., 2008; Rodríguez et al., 2005). Por otro lado, análisis histológicos de testículos de peces tratados con luz continua han mostrado que existe una fuerte reducción de la proliferación espermatogonial (Carrillo, M., Felip, A., Molés, G., Yilmaz, O., Zanuy, S., en consideración). Puesto que, la 11-KT es un andrógeno clave en la iniciación de la proliferación espermatogonial (Schulz et al., 2010) y dado el efecto estimulador de la FSH de lubina en la producción de 11-KT en cultivos in vitro de fragmentos de testículo (Molés et al., 2008, Molés et al., 2011a o presente Tesis Doctoral), todo parece indicar que el tratamiento de luz continua reduce la precocidad influyendo negativamente sobre la síntesis de FSH, lo que causa una disminución de los niveles de 11-KT y como consecuencia una reducción de la proliferación espermatogonial y del crecimiento testicular. 
Por último, se estudió el papel de las GTHs durante el la gametogénesis. Para ello se analizaron los perfiles de FSH en machos y hembras adultas a lo largo de un ciclo reproductor. Anteriormente Rocha et al. (2009) habían estudiado los perfiles plasmáticos de LH y esteroides sexuales (11-KT y E2) en los mismos animales.

En machos, los niveles de FSH en plasma incrementaron considerablemente durante la recrudescencia testicular (estados II a IV) y disminuyeron justo antes de la espermiación (estado V) (ver Fig. 6, pag. 202). El perfil de FSH en plasma fue idéntico al observado anteriormente para la 11-KT (Rocha et al., 2009), resaltando la importancia de la FSH en la regulación de las fases tempranas-medias de la espermatogénesis pero no en espermiogénesis y espermiación. Por el contrario, el perfil de LH mostró un ligero incremento durante el crecimiento testicular, con niveles muy inferiores a los de FSH, que se mantuvieron hasta la espermiación (Rocha et al., 2009). En machos de trucha arcoiris se observo algo parecido, en estos, los niveles plasmáticos de FSH fueron más altos que los de LH durante todas las fases de la espermatogénesis, con máximos niveles de FSH detectados durante la fase de crecimiento testicular medio y tardío (Prat et al., 1996). Por el contrario, los niveles de LH en plasma, en la misma especie, no se detectaron durante la mayor parte del proceso $(<0,3 \mathrm{ng} / \mathrm{ml})$ y únicamente aumentaron durante la espermiación (Prat et al., 1996). Por tanto, al igual que en salmónidos, se puede afirmar que en machos de lubina la FSH tiene un papel claro en la iniciación y mantenimiento de la espermatogénesis, mediado por la 11-KT, mientras que la LH estaría más implicada en las fases de espermiogénesis y espermiación.

En hembras, los perfiles hipofisarios de FSH y de LH fueron idénticos (ver Fig. 6, pag. 174). Los niveles de ambas hormonas fueron significativamente altos durante la vitelogénesis tardía, post-vitelogénesis y maduración-ovulación, con una tendencia a disminuir en el estado de atresia, al final de la temporada reproductiva. En plasma, se observaron niveles máximos de FSH durante todo el proceso de vitelogénesis y post-vitelogénesis y mínimos significativos en maduración-ovulación (ver Fig. 6, pag. 202). Estos resultados indican una activa síntesis y secreción de FSH en vitelogénesis, y una posterior acumulación en hipófisis durante la maduración-ovulación. Al mismo tiempo, los niveles máximos de bioactividad de FSH en plasma se observaron en vitelogénesis tardía y post-vitelogénesis, disminuyendo después de forma gradual hasta el estado de atresia (ver Fig. 6, pag. 174). Por el contra- 
rio, los niveles máximos de LH en plasma se observaron en maduraciónovulación (Rocha et al., 2009), aunque su concentración fue siempre muy inferior a la de FSH durante todo el proceso de oogénesis. Los resultados obtenidos sugieren una síntesis y acumulación semejante de FSH y LH en la hipófisis, pero un control distinto de la secreción al torrente sanguíneo. Los perfiles plasmáticos de GTHs obtenidos en hembras de lubina son similares a los observados en algunas especies con desarrollo ovárico síncrono, como el salmón coho, donde Swanson (1991) describió que la concentración de FSH en plasma aumentaba durante la vitelogénesis, con máximos niveles durante la fase media-tardía de la misma, y disminuía a medida que la ovulación se aproximaba. De forma similar en trucha arcoiris, se describió un incremento significativo de los niveles plasmáticos de FSH en el inicio de la vitelogénesis (Prat et al., 1996), manteniéndose elevados durante la misma y disminuyendo antes de la maduración (Breton et al., 1998). Por el contrario, los niveles de LH alcanzaron máximos en maduración-ovulación (Breton et al., 1998; Prat et al., 1996). Por otro lado, en hembras de lubina se ha observado niveles máximos de expresión de la enzima P450 aromatasa (CYP19A1) y de E2 plasmático (Rocha et al., 2009) durante la vitelogénesis tardía y la post-vitelogénesis, los cuales coincidieron con los máximos plasmáticos de FSH detectados en la presente estudio. Como se comento anteriormente, la enzima CYP19A1 cataliza la conversión de T a E2 y se ha demostrado que la FSH estimula su expresión en folículos vitelogénicos de trucha (Montserrat et al., 2004). Además, varios estudios, incluida esta Tesis Doctoral, han demostrado que el tratamiento con FSH de explantes ováricos o folículos vitelogénicos aislados, aumenta la producción in vitro de E2 (Molés et al., 2008; Molés et al., 2011a; Montserrat et al., 2004; Planas et al., 2000; Suzuki et al., 1988c). En hembras, el E2 estimula la síntesis hepática de vitelogenina, la cual es incorporada progresivamente por los oocitos en crecimiento (Mañanós et al., 1994; Nagahama, 1994). Por lo tanto, de acuerdo con los resultados obtenidos y con la bibliografía existente, se desprende que en la lubina, al igual que en otras especies de teleósteos analizadas, la FSH regula la vitelogénesis mediante la producción ovárica de E2 a través de la activación de la enzima CYP19A1, mientras que la LH sería responsable de los eventos finales de la oogénesis, como son la maduración de los oocitos y la ovulación.

Por otra parte, los ratios B:I de FSH calculados en hipófisis y plasma de hembras adultas durante la gametogénesis fueron menores que los calcula- 
dos en hipófisis durante la diferenciación sexual. En plasma se observo un claro incremento del ratio B:I durante la vitelogénesis tardía y post-vitelogénesis, mientras que en hipófisis disminuyo progresivamente a medida que la oogénesis avanzaba (Tabla 1). Este hecho podría indicar la presencia de isoformas de FSH con diferentes potencias asociadas a el estado reproductivo del animal. En mamíferos se ha sugerido que la microheterogeneidad molecular de FSH en hipófisis y plasma puede cambiar dependiendo de la edad, desarrollo sexual y/o el medio esteroidogénico (Ambao et al., 2009; Rulli et al., 1999; Zariñan et al., 2001). Por ejemplo, en roedores y humanos se ha observado un aumento de formas de FSH menos sializadas (más potentes) durante la fase preovulatoria (Ulloa-Aguirre et al., 1999). Teniendo en cuenta todo esto, nuestros resultados sugieren la presencia de diferentes isoformas de FSH según el estado desarrollo del animal y se podría hipotetizar que durante la diferenciación sexual, serian necesarias isoformas de FSH más potentes pero probablemente menos duraderas en plasma que las presentes durante la oogénesis.

Tabla 1. Ratios de determinación Biológica e Inmunologica (B:I).

\begin{tabular}{llllll|llllll}
\hline & \multicolumn{9}{c|}{ Diferenciación sexual (dph) } & \multicolumn{5}{c}{ Ciclo reproductor (estado) } \\
& & $\mathbf{1 5 0}$ & $\mathbf{2 0 0}$ & $\mathbf{2 5 0}$ & $\mathbf{3 0 0}$ & Prevtg & evtg & lvtg-pvtg & mad-ovul & atre \\
\hline \multirow{2}{*}{ Hipófisis } & Machos & 0,08 & 0,14 & 0,22 & 0,29 & & & & & & \\
& & Hembras & 0,01 & 0,39 & 0,34 & 0,39 & 0,33 & 0,17 & 0,13 & 0,11 & 0,09 \\
Plasma & Hembras & & & & & 0,001 & 0,04 & 0,12 & 0,07 & 0,02 \\
\hline
\end{tabular}

Nota: Para poder comparar mejor los ratios obtenidos en diferentes experimentos, estos se han calculado a partir de las concentraciones obtenidas en $\mathrm{ng} / \mathrm{ml}$.

Por último, cabe señalar que en general los niveles de LH en plasma fueron siempre inferiores a los de FSH, cuyos valores basales estuvieron alrededor de $15 \mathrm{ng} / \mathrm{ml}$, tanto en machos como en hembras. Hecho que podría estar relacionado con la diferente estabilidad de ambas GTHs, ya que los análisis farmacocinéticos realizados en la presente Tesis Doctoral (Molés et al 2011a) y en otros estudios con mamíferos (Campbell, 2005), muestran una mayor estabilidad en sangre para FSH que para LH y consecuentemente, un mayor ratio de eliminación plasmática para LH. Además, durante el proceso de purificación de GTHs nativas de lubina quedó patente que la LH se disocia más fácilmente que la FSH. Todos estos datos sugieren que en la lubina 
podrían ser necesarios altos niveles de FSH en plasma para la estimulación a largo plazo del crecimiento gonadal, mientras que elevaciones puntuales de los niveles de LH podrían tener un efecto más específico en ciertas fases del ciclo reproductor que requerirían de una rápida eliminación.

En resumen, los resultados obtenidos muestran que la FSH tiene un papel clave durante la diferenciación sexual de la lubina, y sugieren un dimorfismo sexual en la síntesis y potencia de la misma. En machos juveniles, los tratamientos de luz continua reducen significativamente los niveles de FSH y, probablemente como consecuencia, la maduración sexual precoz. Por ultimo, los análisis en lubinas adultas muestran que la FSH tiene un papel importante durante la recrudescencia testicular y el crecimiento secundario del oocito (vitelogénesis), mientras que la LH seria responsable de eventos finales como espermiogénesis-espermiación en machos y maduración-ovulación en hembras. Para terminar, cabe decir que los ensayos desarrollados han permitido obtener una visión más amplia y exacta de la función de la FSH en la lubina, contribuyendo al esclarecimiento de la dualidad funcional de las GTHs. Ademas, dichos ensayos representan una valiosa herramienta para futuros estudios en la endocrinología reproductiva de esta especie. 

Capítulo 9. CONCLUSIONES 



\section{Conclusiones}

Primera: Tanto la FSH nativa de lubina, como las GTHs recombinantes producidas en este estudio, activan a sus respectivos receptores de manera específica y dosis dependiente, sin mostrar actividad cruzada en un amplio rango de concentraciones. Además, son capaces de inducir la síntesis de esteroides sexuales en cultivos in vitro de ovario y de testículo. En el caso de la FSH, esta estimulación es mayor en machos en recrudescencia testicular y en hembras vitelogénicas.

Segunda: El sistema de expresión baculovirus, en células Sf9, es más eficiente en términos de producción que las transfecciones estables de células $\mathrm{CHO}$ y produce formas diméricas de FSH menos glicosiladas pero más bioactivas. Por el contrario, las células $\mathrm{CHO}$ producen formas recombinantes con glicosilaciones complejas que les confiere mayor estabilidad en sangre. A su vez, dentro de cada sistema, la estabilidad en sangre de las FSHs es mayor que la de las LHs.

Tercera: Los ensayos desarrollados para medir FSH han permitido determinar, por primera vez en lubinas de ambos sexos, los niveles plasmáticos e hipofisarios de esta hormona en diversos momentos de su proceso reproductor y bajo diferentes condiciones experimentales.

Cuarta: Los perfiles hormonales obtenidos durante la diferenciación sexual sugieren que la FSH tiene un papel importante en este proceso y que sbGnRH, y en menor medida sGnRH, regula su síntesis y secreción a través de la activación del dlGnRH-R-2A (actualmente denominado dlGnRHRII-1a). Además, los diferentes niveles de FSH y los ratios B:I en machos y hembras sugiere un dimorfismo sexual en la síntesis y potencia de la FSH. 
Quinta: Los análisis inmunohistoquímicos en hipófisis de lubinas adultas muestran que, como en otras especies de teleósteos, la FSH y la LH se sintetizan en diferentes poblaciones de células de la adenohipófisis.

Sexta: El tratamiento de machos juveniles de lubina con luz continua reduce los niveles de FSH en plasma. Esto previene la pubertad precoz de los mismos, probablemente como consecuencia de una disminución de la proliferación espermatogonial y del crecimiento testicular.

Séptima: Los perfiles de GTHs en lubinas adultas sugieren una síntesis y acumulación similar de FSH y LH en hipófisis, pero un control distinto de su secreción al torrente sanguíneo. Además, dichos perfiles indican que la FSH tiene un papel clave en la iniciación y mantenimiento de la espermatogénesis y en la vitelogénesis, mientras que la LH parece estar involucrada en las fases de espermiogénesis, espermiación, maduración de los oocitos y ovulación.

Octava: La mayor cantidad y estabilidad de la FSH en sangre durante el ciclo reproductor sugiere que esta podría ser necesaria para una estimulación a largo plazo del crecimiento gonadal, mientras que en el caso de la LH solo se requerirían elevaciones puntuales para un efecto más específico en las fases finales de la gametogénesis.

Novena: Los diferentes ratios B:I de FSH calculados en hipófisis y plasma sugieren la presencia de isoformas con diferentes potencias según el estado desarrollo del animal. Siendo en hipófisis, aparentemente más potentes durante la diferenciación sexual que durante la oogénesis, y dentro de esta última, en plasma, más potente durante la vitelogénesis tardía y postvitelogénesis. 




\section{BIBLIOGRAFÍA GENERAL}





\section{Bibliografía general}

Adams, B.A., Vickers, E.D., Warby, C., Park, M., Fischer, W.H., Grey Craig, A., Rivier, J.E., Sherwood, N.M., 2002. Three forms of gonadotropin-releasing hormone, including a novel form, in a basal salmonid, Coregonus clupeaformis. Biol. Reprod. 67, 232-239.

Aizen, J., Kasuto, H., Golan, M., Zakay, H., Levavi-Sivan, B., 2007a. Tilapia follicle-stimulating hormone (FSH): immunochemistry, stimulation by gonadotropin-releasing hormone, and effect of biologically active recombinant FSH on steroid secretion. Biol Reprod. 76, 692-700.

Aizen, J., Kasuto, H., Levavi-Sivan, B., 2007b. Development of specific enzyme-linked immunosorbent assay for determining LH and FSH levels in tilapia, using recombinant gonadotropins. Gen. Comp. Endocrinol. 153, 323-332.

Albanese, C., Christin-Maitre, S., Sluss, P. M., Crowley, W. F., Jameson, J. L., 1994. Development of a bioassay for FSH using a recombinant human FSH receptor and a cAMP responsive luciferase reporter gene. Mol. Cell. Endocrinol. 101, 211-219.

Ambao, V., Rulli, S. B., Carino, M. H., Console, G., Ulloa-Aguirre, A., Calandra, R. S., Campo, S., 2009. Hormonal regulation of pituitary FSH sialylation in male rats. Mol. Cell. Endocrinol. 309, 39-47.

Ascoli, M., Fanelli, F., Segaloff, D. L., 2002. The lutropin/choriogonadotropin receptor, a 2002 perspective. Endocr. Rev. 23, 141-174.

Asturiano, J. F., Sorbera, L. A., Ramos, J., Kime, D. E., Carrillo, M., Zanuy, S., 2000. Hormonal regulation of the European sea bass reproductive cycle: an individualized female approach. J. Fish Biol. 56, 1155-1172.

Asturiano, J. F., Sorbera, L. A., Ramos, J., Kime, D. E., Carrillo, M., Zanuy, S., 2002. Groupsynchronous ovarian development, ovulation and spermiation in the European sea bass (Dicentrarchus labrax L.) could be regulated by shifts in gonadal steroidogenesis. Sci. Mar. 66, 273-282.

Barnabé, G., 1991. La cría de la lubina y de la dorada. In: G. Barnabe, (Ed.), Acuicultura. Omega, S.A., Barcelona, pp. 573-612.

Begtashi, I., Rodriguez, L., Molés, G., Zanuy, S., Carrillo, M., 2004. Long-term exposure to continuous light inhibits precocity in juvenile male European sea bass (Dicentrarchus labrax, L.). I. Morphological aspects. Aquaculture. 241, 539-559.

Ben-Menahem, D., Boime, I., 1996. Converting heterodimeric gonadotropins to genetically linked single chains: New approaches to structure activity relationships and analogue design. Trends Endocrinol. Metab. 7, 100-105.

Billard, R., Fostier, A., Weil, C., Breton, B., 1982. Endocrine control of spermatogenesis in teleost fish. Can. J. Fish. Aquat. Sci. 39, 65-79.

Blaise, O., Szkudlindski, M., Hassin, S., Stubblefield, J., Weintraub, B., Zohar, Y., 2000. Production of recombinant striped bass (Morone saxatilis) gonadotropins in Chinese hamster ovarian $(\mathrm{CHO})$ cell expression system. In: Norberg, B. et al. (Eds.), Sixth International Symposium on Reproductive Physiology of Fish. University of Bergen, pp. 482.

Blázquez, M., Carrillo, M., Zanuy, S., Piferrer, F., 1999. Sex ratios in offspring of sex-reversed sea bass and the relationship between growth and phenotypic sex differentiati- 
on. J. Fish Biol. 55, 916-930.

Blázquez, M., Piferrer, F., 2004. Cloning, sequence analysis, tissue distribution, and sexspecific expression of the neural form of $\mathrm{P} 450$ aromatase in juvenile sea bass (Dicentrarchus labrax). Mol. Cell. Endocrinol. 219, 83-94.

Bogerd, J., Granneman, J. C., Schulz, R. W., Vischer, H. F., 2005. Fish FSH receptors bind LH: how to make the human FSH receptor to be more fishy?. Gen. Comp. Endocrinol. 142, 34-43.

Borg, B., 1994. Androgens in teleost fishes. Comp. Biochem. Physiol. C Toxicol. Pharmacol. 109, 219-245.

Bousfield, G. R., Perry, W. M., Ward, D. N., 1994. Gonadotropins. Chemistry and biosynthesis. In: E. Knobil, J. D. Neill, (Eds.), The Physiology of Reproduction. Raven Press, New York, pp. 1749-1792.

Braun, T., Schofield, P. R., Sprengel, R., 1991. Amino-Terminal Leucine-Rich Repeats in Gonadotropin Receptors Determine Hormone Selectivity. Embo J. 10, 1885-1890.

Breton, B., Govoroun, M., Mikolajczyk, T., 1998. GTH I and GTH II secretion profiles during the reproductive cycle in female rainbow trout: Relationship with pituitary responsiveness to GnRH-A stimulation. Gen. Comp. Endocrinol. 111, 38-50.

Burgus, R., Butcher, M., Ling, N., Monahan, M., Rivier, J., Fellows, R., Amoss, M., Blackwell, R., Vale, W., Guillemin, R., 1971. Molecular structure of the hypothalamic factor (LRF) of ovine origin monitoring the secretion of pituitary gonadotropic hormone of luteinization (LH). C. R. Acad. Sci. Hebd. Seances Acad. Sci. D. 273, 1611-1613.

Burzawa-Gerard, E., Fontaine, Y. A., 1972. The Gonadotropins of lower Vertebrates. Gen. Comp. Endocrinol. 3, 715-728.

Calman, B., Lin, Y. W. P., Wallace, R. A., 2001. Preparation and use of specific antibodies to the beta-I and beta-II subunits of gonadotropic hormone from Fundulus heteroclitus pituitary. Gen. Comp. Endocrinol. 123, 203-209.

Campbell, R. K., 2005. Molecular pharmacology of gonadotropins. Endocrine. 26, 291296.

Carolsfeld, J., Powell, J.F., Park, M., Fischer, W.H., Craig, A.G., Chang, J.P., Rivier, J.E., Sherwood, N.M., 2000. Primary structure and function of three gonadotropin-releasing hormones, including a novel form, from an ancient teleost, herring. Endocrinology 141, 505-512.

Carrillo, M., Zanuy, S., Prat, F., Cerdà, J., Mañanós, E., Bromage, N. R., 1995. Sea bass (Dicentrarchus labrax). In: N. R. Bromage, R. J. Roberts, (Eds.), Broodstock Management and Egg and Larval Quality. Blackwell Science, London, pp. 138-168.

Cerdà, J., 2009. Mecanismos moleculares durante la maduración y ovulación del oocito de teleósteos: avances recientes y su aplicación en acuicultura. In: J. E. de los Monteros, M. Carrillo, (Eds.), La reproducción de los peces: aspectos básicos y sus aplicaciones en acuicultura. Publicaciones Cientificas y Tecnológicas de la Fundación Observatorio Español de Acuicultura, Madrid, pp. 403-474.

Choi, E., Ko, H., Shin, J., Kim, M.-A., Sohn, Y.C., 2005. Expression of gonadotropin genes in Manchurian trout Brachymystax lenok and production of recombinant gonadotropins. Fish Sci. 71, 1193-1200.

Christin-Maitre, S., Bouchard, P., 1996. Bioassays of gonadotropins based on cloned receptors. Mol. Cell. Endocrinol. 125, 151-159.

Christin-Maitre, S., Taylor, A. E., Khoury, R. H., Hall, J. E., Martin, K. A., Smith, P. C., 
Albanese, C., Jameson, J. L., Crowley, W. F., Sluss, P. M., 1996. Homologous in vitro bioassay for follicle-stimulating hormone (FSH) reveals increased FSH biological signal during the mid- to late luteal phase of the human menstrual cycle. J. Clin. Endocrinol. Metab. 81, 2080-2088.

Christin-Maitre, S., Vasseur, C., Fauser, B., Bouchard, P., 2000. Bioassays of gonadotropins. Methods. 21, 51-57.

Copeland, P. A., Thomas, P., 1989. Purification of maturational gonadotropin from Atlantic croaker (Micropogonias undulatus) and development of a homologous radioimmunoassay. Gen. Comp. Endocrinol. 73, 425-441.

Copeland, P. A., Thomas, P., 1993. Isolation of gonadotropin subunits and evidence for two distinct gonadotropins in Atlantic croaker (Micropogonias undulatus). Gen. Comp. Endocrinol. 91, 115-125.

Corless, C. L., Bielinska, M., Ramabhadran, T. V., Daniels-McQueen, S., Otani, T., Reitz, B. A., Tiemeier, D. C., Boime, I., 1987a. Gonadotropin alpha subunit. Differential processing of free and combined forms in human trophoblast and transfected mouse cells. J. Biol. Chem. 262, 14197-14203.

Corless, C. L., Matzuk, M. M., Ramabhadran, T. V., Krichevsky, A., Boime, I., 1987b. Gonadotropin Beta Subunits Determine the Rate of Assembly and the Oligosaccharide Processing of Hormone Dimer in Transfected Cells. J. Cell Biol. 104, 1173-1181.

Cui, M., Li, W., Liu, W., Yang, K., Pang, Y., Haoran, L., 2007. Production of recombinant orange-spotted grouper (Epinephelus coioides) luteinizing hormone in insect cells by the baculovirus expression system and its biological effect. Biol. Reprod. 76, 74-84.

Devlin, R. H., Nagahama, Y., 2002. Sex determination and sex differentiation in fish: an overview of genetic, physiological, and environmental influences. Aquaculture. 208, 191-364.

Dias, J. A., Cohen, B. D., Lindau-Shepard, B., Nechamen, C. A., Peterson, A. J., Schmidt, A., 2002. Molecular, structural, and cellular biology of follitropin and follitropin receptor. Vitam. Horm. 64, 249-322.

Dias, J. A., Mahale, S. D., Nechamen, C. A., Davydenko, O., Thomas, R. M., Ulloa-Aguirre, A., 2010. Emerging roles for the FSH receptor adapter protein APPL1 and overlap of a putative 14-3-3 tau interaction domain with a canonical G-protein interaction site. Mol. Cell. Endocrinol. 329, 17-25.

Fan, Q. R., Hendrickson, W. A., 2005. Structure of human follicle-stimulating hormone in complex with its receptor. Nature. 433, 269-277.

Fares, F. A., Suganuma, N., Nishimori, K., Lapolt, P. S., Hsueh, A. J. W., Boime, I., 1992. Design of a Long-Acting Follitropin Agonist by Fusing the C-Terminal Sequence of the Chorionic-Gonadotropin Beta-Subunit to the Follitropin Beta-Subunit. Proc. Natl. Acad. Sci. U.S.A. 89, 4304-4308.

Feist, G., Schreck, C. B., 1996. Brain-pituitary-gonadal axis during early development and sexual differentiation in the rainbow trout, Oncorhynchus mykiss. Gen. Comp. Endocrinol. 102, 394-409.

Felip, A., Zanuy, S., Muriach, B., Cerdá-Reverter, J. M., Carrillo, M., 2008. Reduction of sexual maturation in male Dicentrarchus labrax by continuous light both before and during gametogenesis. Aquaculture. 275, 347-355.

Fernald, R. D., White, R. B., 1999. Gonadotropin-releasing hormone genes: phylogeny, structure, and functions. Front Neuroendocrinol. 20, 224-40. 
Fink, G., 2000. Neuroendocrine regulation of pituitary function: general principles. In: P. M. Conn, M. E. Freeman, (Eds.), Neuroendocrinology in Physiology and Medicine Human Press Inc., Totowa, New Jersey, pp. 107-134.

Fostier, A., Jalabert, B., Billard, R., Breton, B., Zohar, Y., 1983. The gonadal steroids. In: E. M. Donaldson, (Ed.), Fish Physiology. Academic Press, New York, pp. 277-372.

Fox, K. M., Dias, J. A., Van Roey, P., 2001. Three-dimensional structure of human folliclestimulating hormone. Mol. Endocrinol. 15, 378-389.

García-Ayala, A., García-Hernández, M. P., Quesada, J. A., Agulleiro, B., 1998. Gonadotropic and thyrotropic cells from the Mediterranean yellowtail (Seriola dumerilii; Risso, 1810): Immunocytochemical and ultrastructural characterization. Anat. Rec. 250, 448458.

García Hernández, M. P., García Ayala, A., Agulleiro, B., García, A., van Dijk, W., Schulz, R. W., 2002. Development of a homologous radioimmunoassay for Mediterranean yellowtail (Seriola dumerilii, Risso 1810) LH. Aquaculture. 210, 203-218.

García-Hernández, M. P., Koide, Y., Diaz, M. V., Kawauchi, H., 1997. Isolation and characterization of two distinct gonadotropins from the pituitary gland of Mediterranean yellowtail, Seriola dumerilii (Risso, 1810). Gen. Comp. Endocrinol. 106, 389-399.

García-López, A., Bogerd, J., Granneman, J. C. M., van Dijk, W., Trant, J. M., Taranger, G. L., Schulz, R. W., 2009. Leydig Cells Express Follicle-Stimulating Hormone Receptors in African Catfish. Endocrinology. 150, 357-365.

García-López, A., de Jonge, H., Nobrega, R. H., de Waal, P. P., van Dijk, W., Hemrika, W., Taranger, G. L., Bogerd, J., Schulz, R. W., 2010. Studies in Zebrafish Reveal Unusual Cellular Expression Patterns of Gonadotropin Receptor Messenger Ribonucleic Acids in the Testis and Unexpected Functional Differentiation of the Gonadotropins. Endocrinology. 151, 2349-2360.

Gates, R., Rathbone E., Masterson L., Wright I., Electricwala, A., 2004. Glycoprotein analysis manual. Sigma-Aldrich. First Edition (www.sigmaaldrich.com).

Gómez, J. M., Weil, C., Ollitrault, M., Le Bail, P. Y., Breton, B., Le Gac, F., 1999. Growth hormone $(\mathrm{GH})$ and gonadotropin subunit gene expression and pituitary and plasma changes during spermatogenesis and oogenesis in rainbow trout (Oncorhynchus mykiss). Gen. Comp. Endocrinol. 113, 413-428.

González-Martínez, D., Madigou, T., Mañanós, E., Cerda-Reverter, J. M., Zanuy, S., Kah, O., Muñoz-Cueto, J. A., 2004. Cloning and expression of gonadotropin-releasing hormone receptor in the brain and pituitary of the European sea bass: an in situ hybridization study. Biol. Reprod. 70, 1380-1391.

González-Martínez, D., Zmora, N., Mañanós, E., Saligaut, D., Zanuy, S., Zohar, Y., Elizur, A., Kah, O., Muñoz-Cueto, J. A., 2002a. Immunohistochemical localization of three different prepro-GnRHs in the brain and pituitary of the European Sea Bass (Dicentrarchus labrax) using antibodies to the corresponding GnRH-associated peptides. J. Comp. Neurol. 446, 95-113.

González-Martínez, D., Zmora, N., Zanuy, S., Sarasquete, C., Elizur, A., Kah, O., MuñozCueto, J. A., 2002b. Developmental expression of three different prepro-GnRH (Gonadotrophin-releasing hormone) messengers in the brain of the European sea bass (Dicentrarchus labrax). J. Chem. Neuroanat. 23, 255-267.

Govoroun, M., Chyb, J., Breton, B., 1998. Immunological cross-reactivity between rainbow trout GTH I and GTH II and their alpha and beta subunits: Application to the develop- 
ment of specific radioimmunoassays. Gen. Comp. Endocrinol. 111, 28-37.

Govoroun, M. S., Huet, J. C., Pernollet, J. C., Breton, B., 1997. Use of immobilized metal ion affinity chromatography and dye-ligand chromatography for the separation and purification of rainbow trout pituitary gonadotropins, GTH I and GTH II. J. Chromatogr. B Biomed. Sci. Appl. 698, 35-46.

Grier, H. J., 1993. Comparative organization of Sertoli cells including the Sertoli cell barrier. In: L. D. Russell, M. D. Griswold, (Eds.), The Sertoli Cell. Cache River Press, Saint Louis, pp. 704-739.

Grier, H. J., Lo Nostro, F. L., 2000. The teleost germinal epithelium: a unifying concept. Proceedings of the 6th International Symposium on Reproductive Physiology of Fish. University of Bergen, Bergen, pp. 233-236.

Grinna, L. S., Tschopp, J. F., 1989. Size Distribution and General Structural Features of N-Linked Oligosaccharides from the Methylotrophic Yeast, Pichia pastoris. Yeast. 5, 107-115.

Gudermann, T., Brockmann, H., Simoni, M., Gromoll, J., Nieschlag, E., 1994. In-Vitro Bioassay for Human Serum Follicle-Stimulating Hormone (FSH) Based on L Cells Transfected with Recombinant Rat FSH Receptor: Validation of a Model System. Endocrinology. 135, 2204-2213.

Hearn, M. T., Gomme, P. T., 2000. Molecular architecture and biorecognition processes of the cystine knot protein superfamily: part I. The glycoprotein hormones. J. Mol. Recognit. 13, 223-278.

Helenius, A., Aebi, M., 2001. Intracellular functions of N-linked glycans. Science. 291, 2364-2369.

Hew, C., Trinh, K., Du, S., Song, S., 1989. Molecular cloning and expression of salmon pituitary hormones. Fish Physiol. Biochem. 7, 375-380.

Huang, C. J., Huang, F. L., Chang, G. D., Chang, Y. S., Lo, C. F., Fraser, M. J., Lo, T. B., 1991. Expression of two forms of carp gonadotropin à subunit in insect cells by recombinant baculovirus. Proc. Natl. Acad. Sci. USA. 88, 7486-7490.

Jalabert, B., 2005. Particularities of reproduction and oogenesis in teleost fish compared to mammals. Reprod. Nutr. Dev. 45, 261-279.

Jia, X. C., Perlas, E., Su, J. G., Moran, F., Lasley, B. L., Ny, T., Hsueh, A. J., 1993. Luminescence luteinizing hormone/choriogonadotropin (LH/CG) bioassay: measurement of serum bioactive LH/CG during early pregnancy in human and macaque. Biol. Reprod. 49, 1310-1316.

Jiménez-Liñán, M., Rubin, B.S., King, J.C., 1997. Examination of guinea pig luteinizing hormone-releasing hormone gene reveals a unique decapeptide and existence of two transcripts in the brain. Endocrinology 138, 4123-4130.

Kagawa, H., Kawazoe, I., Tanaka, H., Okuzawa, K., 1998a. Immunocytochemical identification of two distinct gonadotropic cells (GTH I and GTH II) in the pituitary of bluefin tuna, Thunnus thynnus. Gen. Comp. Endocrinol. 110, 11-18.

Kagawa, H., Tanaka, H., Okuzawa, K., Kobayashi, M., 1998b. GTH II but not GTH I induces final maturation and the development of maturational competence of oocytes of red seabream in vitro. Gen. Comp. Endocrinol. 112, 80-88.

Kah, O., Lethimonier, C., Somoza, G., Guilgur, L. G., Vaillant, C., Lareyre, J. J., 2007. GnRH and $\mathrm{GnRH}$ receptors in metazoa: a historical, comparative, and evolutive perspective. Gen. Comp. Endocrinol. 153, 346-364. 
Kah, O., Pontet, A., Nuñez Rodríguez, J., Calas, A., Breton, B., 1989. Development of an enzyme-linked immunosorbent assay for goldfish gonadotropin. Biol. Reprod. 41, 68-73.

Kajitani, T., Liu, S., Maruyama, T., Uchida, H., Sakurai, R., Masuda, H., Nagashima, T., Ono, M., Arase, T., Yoshimura, Y., 2008. Analysis of serum FSH bioactivity in a patient with an FSH-secreting pituitary microadenoma and multicystic ovaries: A case report. Human Reproduction. 23, 435-439.

Kamei, H., Kawazoe, I., Kaneko, T., Aida, K., 2005. Purification of follicle-stimulating hormone from immature Japanese eel, Anguilla japonica, and its biochemical properties and steroidogenic activities. Gen. Comp. Endocrinol. 143, 257-266.

Kamei, H., Ohira, T., Yoshiura, Y., Uchida, N., Nagasawa, H., Aida, K., 2003. Expression of a biologically active recombinant follicle stimulating hormone of Japanese Eel Anguilla japonica using methylotropic yeast, Pichia pastoris. Gen. Comp. Endocrinol. 134, 24454.

Kasuto, H., Levavi-Sivan, B., 2005. Production of biologically active tethered tilapia LH $\beta \alpha$ by the methylotrophic yeast Pichia pastoris. Gen. Comp. Endocrinol. 140, 222-232.

Kavanaugh, S. I., Nozaki, M., Sower, S. A., 2008. Origins of gonadotropin-releasing hormone $(\mathrm{GnRH})$ in vertebrates: identification of a novel $\mathrm{GnRH}$ in a basal vertebrate, the sea lamprey. Endocrinology. 149, 3860-9.

Kawauchi, H., Suzuki, K., Nagahama, Y., Adachi, N., Naito, N., Nakai, Y., Yoshimura, F., Gorbman, A., 1986. Occurrence of two distinct gonadotropins in chum salmon pituitary. Pars Distalis of the Pituitary Gland: Structure, Function and Regulation. Elsevier, Amsterdam, pp. 383-390.

Kazeto, Y., Kohara, M., Miura, T., Miura, C., Yamaguchi, S., Trant, J. M., Adachi, S., Yamauchi, K., 2008. Japanese eel follicle-stimulating hormone (Fsh) and luteinizing hormone (Lh): production of biologically active recombinant Fsh and Lh by Drosophila S2 cells and their differential actions on the reproductive biology. Biol. Reprod. 79, 938-46.

Keene, J. L., Matzuk, M. M., Otani, T., Fauser, B. C., Galway, A. B., Hsueh, A. J., Boime, I., 1989. Expression of biologically active human follitropin in Chinese hamster ovary cells. J. Biol. Chem. 264, 4769-4775.

Kelton, C. A., Cheng, S. V. Y., Nugent, N. P., Schweickhardt, R. L., Rosenthal, J. L., Overton, S. A., Wands, G. D., Kuzeja, J. B., Luchette, C. A., Chappel, S. C., 1992. The cloning of the human follicle stimulating hormone receptor and its expression in COS-7, CHO, and Y-1 cells. Mol. Cell. Endocrinol. 89, 141-151.

Klein, J., Lobel, L., Pollak, S., Lustbader, B., Ogden, R. T., Sauer, M. V., Lustbader, J. W., 2003. Development and characterization of a long-acting recombinant hFSH agonist. Hum. Reprod. 18, 50-56.

Kleizen, B., Braakman, I., 2004. Protein folding and quality control in the endoplasmic reticulum. Curr. Opin. Cell Biol. 16, 343-349.

Ko, H., Park, W., Kim, D. J., Kobayashi, M., Sohn, Y. C., 2007. Biological activities of recombinant Manchurian trout FSH and LH: their receptor specificity, steroidogenic and vitellogenic potencies. J. Mol. Endocrinol. 38, 99-111.

Kobayashi, M., Aida, K., Hanyu, I., 1985. Radioimmunoassay for silver carp gonadotropin. Bull. Japan. Soc. Sci. Fish., 51, 1085-1091.

Kobayashi, M., Aida, K., Sakai, H., Kaneko, T., Asahina, K., Hanyu, I., Ishii, S., 1987. Radioimmunoassay for Salmon Gonadotropin. Nippon Suisan Gakkaishi. 53, 995-1003.

Kobayashi, M., Hayakawa, Y., Park, W., Banba, A., Yoshizaki, G., Kumamaru, K., Kagawa, 
H., Kaki, H., Nagaya, H., Sohn, Y. C., 2010a. Production of recombinant Japanese eel gonadotropins by baculovirus in silkworm larvae. Gen. Comp. Endocrinol. 167, 379-386.

Kobayashi, M., Morita, T., Ikeguchi, K., Yoshizaki, G., Suzuki, T., Watabe, S., 2003. Production of recombinant goldfish gonadotropins by baculovirus in silkworm larvae. Fish Physiol. Biochem. 28, 469-471.

Kobayashi, M., Morita, T., Ikeguchi, K., Yoshizaki, G., Suzuki, T., Watabe, S., 2006. In vivo biological activity of recombinant goldfish gonadotropins produced by baculovirus in silkwonn larvae. Aquaculture 256, 433-442.

Kobayashi, Y., Alam, M. A., Horiguchi, R., Shimizu, A., Nakamura, M., 2010b. Sexually Dimorphic Expression of Gonadotropin Subunits in the Pituitary of Protogynous Honeycomb Grouper (Epinephelus merra): Evidence That Follicle-Stimulating Hormone (FSH) Induces Gonadal Sex Change. Biol. Reprod. 82, 1030-1036.

Koide, Y., Itoh, H., Kawauchi, H., 1993. Isolation and characterization of two distinct gonadotropins, GTHI and GTHII, from bonito (Katsuwonus plelamis) pituitary glands. Int. J. Pept. Protein Res. 41, 52-65.

Kost, T. A., Condreay, J. P., Jarvis, D. L., 2005. Baculovirus as versatile vectors for protein expression in insect and mammalian cells. Nat. Biotechnol. 23, 567-575.

Kwok, H. F., So, W. K., Wang, Y., Ge, W., 2005. Zebrafish gonadotropins and their receptors: I. Cloning and characterization of zebrafish follicle-stimulating hormone and luteinizing hormone receptors--evidence for their distinct functions in follicle development. Biol. Reprod. 72, 1370-1381.

Lapthorn, A. J., Harris, D. C., Littlejohn, A., Lustbader, J. W., Canfield, R. E., Machin, K. J., Morgan, F. J., Isaacs, N. W., 1994. Crystal-Structure of Human Chorionic-Gonadotropin. Nature. 369, 455-461.

Le Menn, F., Cerda, J., Babin, P., 2007. Ultrastructural aspects of the ontogeny and differentiation of ray-finned fish ovarian follicles. In: P. Babin, J. Cerda, E. Lubzens, (Eds.), The Fish Oocyte: From Basic Studies to Biotechnological Applications. Springer, Dordrecht, The Netherlands, pp. 1-37.

Lethimonier, C., Madigou, T., Muñoz-Cueto, J. A., Lareyre, J. J., Kah, O., 2004. Evolutionary aspects of GnRHs, GnRH neuronal systems and GnRH receptors in teleost fish. Gen. Comp. Endocrinol. 135, 1-16.

Levavi-Sivan, B., Bogerd, J., Mañanós, E. L., Gómez, A., Lareyre, J. J., 2010. Perspectives on fish gonadotropins and their receptors. Gen. Comp. Endocrinol. 165, 412-437.

Li, M. D., Ford, J. J., 1998. A comprehensive evolutionary analysis based on nucleotide and amino acid sequences of the $\alpha$ - and $\beta$-subunits of glycoprotein hormone gene family. J. Endocrinol. 156, 529-542.

Lovejoy, D.A., Fischer, W.H., Ngamvongchon, S., Craig, A.G., Nahorniak, C.S., Peter, R.E., Rivier, J.E., Sherwood, N.M., 1992. Distinct sequence of gonadotropin-releasing hormone $(\mathrm{GnRH})$ in dogfish brain provides insight into GnRH evolution. Proc. Natl. Acad. Sci. USA 89, 6373-6377.

Lubzens, E., Young, G., Bobe, J., Cerdà, J., 2010. Oogenesis in teleosts: how eggs are formed. Gen. Comp. Endocrinol. 165, 367-89.

Luckenbach, J.A., Yamamoto, Y., Guzman, J.M., Swanson, P., 2011. Proceedings of the 9th International Symposium on Reproductive Physiology of Fish. Cochin, India, pp. 210211.

Magliulo-Cepriano, L., Schreibman, M. P., Blum, V., 1994. Distribution of Variant Forms 
of Immunoreactive Gonadotropin-Releasing Hormone and $\beta$-Gonadotropins I and II in the Platyfish, Xiphophorus maculatus, from Birth to Sexual Maturity. Gen. Comp. Endocrinol. 94, 135-150.

Mañanós, E. L., Swanson, P., Stubblefield, J., Zohar, Y., 1997. Purification of gonadotropin II from a teleost fish, the hybrid striped bass, and development of a specific enzymelinked immunosorbent assay. Gen. Comp. Endocrinol. 108, 209-222.

Mañanós, E., Zanuy, S., Lemenn, F., Carrillo, M., Nuñez, J., 1994. Sea Bass (Dicentrarchus labrax L) Vitellogenin .1. Induction, Purification and Partial Characterization. Comp. Biochem. Physiol. B Biochem. Mol. Biol. 107, 205-216.

Mateos, J., Mañanós, E., Martínez-Rodríguez, G., Carrillo, M., Querat, B., Zanuy, S., 2003. Molecular characterization of sea bass gonadotropin subunits ( $\alpha, \mathrm{FSH} \beta$, and $\mathrm{LH} \beta$ ) and their expression during the reproductive cycle. Gen. Comp. Endocrinol. 133, 216-232.

Mateos, J., Mañanós, E., Swanson, P., Carrillo, M., Zanuy, S., 2006. Purification of luteinizing hormone $(\mathrm{LH})$ in the sea bass (Dicentrarchus labrax) and development of a specific immunoassay. Cienc. Mar. 32, 271-283.

Matsuo, H., Baba, Y., Nair, R. M. G., Arimura, A., Schally, A. V., 1971. Structure of porcine LH- and FSH-releasing hormone. I. The proposed amino acid sequence. Biochem. Biophys. Res. Commun. 43, 1334-1339.

Maugars, G., Schmitz, M., 2006. Molecular cloning and characterization of FSH and LH receptors in Atlantic salmon (Salmo salar L.). Gen. Comp. Endocrinol. 149, 108-117.

Meiri, I., Zmora, N., Abigail, E., 2000. Functional expression of recombinant seabream FSH and LH in baculovirus infected insect cells. In: Norberg, B. et al. (Eds.), Sixth International Symposium on Reproductive Physiology of Fish. University of Bergen, pp. 488.

Miranda, L. A., Strussmann, C. A., Somoza, G. M., 2001. Immunocytochemical identification of GtH1 and GtH2 cells during the temperature-sensitive period for sex determination in pejerrey, Odontesthes bonariensis. Gen. Comp. Endocrinol. 124, 45-52.

Miyamoto, K., Hasegawa, Y., Minegishi, T., Nomura, M., Takahashi, Y., Igarashi, M., Kangawa, K., Matsuo, H., 1982. Isolation and characterization of chicken hypothalamic luteinizing hormone-releasing hormone. Biochem. Biophys. Res. Commun. 107, 820827.

Miyamoto, K., Hasegawa, Y., Nomura, M., Igarashi, M., Kangawa, K., Matsuo, H., 1984. Identification of the second gonadotropin-releasing hormone in chicken hypothalamus: evidence that gonadotropin secretion is probably controlled by two distinct gonadotropin-releasing hormones in avian species. Proc. Natl. Acad. Sci. USA 81, 3874-3878.

Molés, G., Gómez, A., Rocha, A., Carrillo, M., Zanuy, S., 2008. Purification and characterization of follicle-stimulating hormone from pituitary glands of sea bass (Dicentrarchus labrax). Gen. Comp. Endocrinol. 158, 68-76.

Molés, G., Zanuy, S., Muñoz, I., Crespo, B., Martínez, I., Mañanós, E., Gómez, A., 2011a. Receptor Specificity and Functional Comparison of Recombinant Sea Bass (Dicentrarchus labrax) Gonadotropins (Fsh and Lh) Produced in Different Host Systems. Biol. Reprod. DOI:10.1095/biolreprod.110.086470

Moncaut, N., Somoza, G., Power, D. M., Canario, A. V., 2005. Five gonadotrophin-releasing hormone receptors in a teleost fish: isolation, tissue distribution and phylogenetic relationships. J. Mol. Endocrinol. 34, 767-779.

Montserrat, N., González, A., Mendez, E., Piferrer, F., Planas, J. V., 2004. Effects of follicle 
stimulating hormone on estradiol-17 beta production and P-450 aromatase (CYP19) activity and mRNA expression in brown trout vitellogenic ovarian follicles in vitro. Gen. Comp. Endocrinol. 137, 123-131.

Morita, T., Yoshizaki, G., Kobayashi, M., Takeuchi, T., 2003. Production of biologicallyactive recombinant goldfish gonadotropins in transgenic rainbow trout. Fish Physiol. Biochem 28, 473-474.

Morita, T., Yoshizaki, G., Kobayashi, M., Watabe, S., Takeuchi, T., 2004. Fish eggs as bioreactors: the production of bioactive luteinizing hormone in transgenic trout embryos. Transgenic Res. 13, 551-557.

Moyle, W. R., Campbell, R. K., Myers, R. V., Bernard, M. P., Han, Y., Wang, X. Y., 1994. Coevolution of Ligand-Receptor Pairs. Nature. 368, 251-255.

Muñoz-Cueto, J. A., 2009. Cerebro y reproducción en peces: Bases neurales y neuroendocrinas. In: J. E. de los Monteros, M. Carrillo, (Eds.), La reproducción de los peces: aspectos básicos y sus aplicaciones en acuicultura. Publicaciones Cientificas y Tecnológicas de la Fundacion Observatorio Español de Acuicultura, Madrid, pp. 27-96.

Mylonas, C.C., Zohar, Y., 2001. Endocrine regulation and artificial induction of oocyte maturation and spermiation in basses of the genus Morone. Aquaculture. 202, 205-220.

Nagahama, Y., 1983. The Functional Morphology of Teleost Gonads. In: W. S. Hoar, D. J. Randall, E. M. Donaldson, (Eds.), Fish Physiology. Academic Press, New York, pp. 223275.

Nagahama, Y., 1994. Endocrine regulation of gametogenesis in fish. Int. J. Dev. Biol. 38, 217-229.

Nagahama, Y., Yamashita, M., 2008. Regulation of oocyte maturation in fish. Dev. Growth Differ. 50, S195-S219.

Nakabayashi, K., Matsumi, H., Bhalla, A., Bae, J., Mosselman, S., Hsu, S. Y., Hsueh, A. J. W., 2002. Thyrostimulin, a heterodimer of two new human glycoprotein hormone subunits, activates the thyroid-stimulating hormone receptor. J. Clin. Invest. 109, 1445-1452.

Ngamvongchon, S., Sherwood, N.M., Warby, C.M., Rivier, J.E., 1992. Gonadotropin-releasing hormone from thai catfish: chromatographic and physiological studies. Gen. Comp. Endocrinol. 87, 266-274.

Nozaki, M., Naito, N., Swanson, P., Dickhoff, W. W., Nakai, Y., Suzuki, K., Kawauchi, H., 1990. Salmonid pituitary gonadotrophs. II. Ontogeny of GTH I and GTH II cells in the rainbow trout (Salmo gairdneri irideus). Gen. Comp. Endocrinol. 77, 358-367.

Oba, Y., Hirai, T., Yoshiura, Y., Yoshikuni, M., Kawauchi, H., Nagahama, Y., 1999a. Cloning, functional characterization, and expression of a gonadotropin receptor cDNA in the ovary and testis of amago salmon (Oncorhynchus rhodurus). Biochem. Biophys. Res. Commun. 263, 584-90.

Oba, Y., Hirai, T., Yoshiura, Y., Yoshikuni, M., Kawauchi, H., Nagahama, Y., 1999b. The duality of fish gonadotropin receptors: cloning and functional characterization of a second gonadotropin receptor cDNA expressed in the ovary and testis of amago salmon (Oncorhynchus rhodurus). Biochem. Biophys. Res. Commun. 265, 366-71.

Okada, T., Kawazoe, I., Kimura, S., Sasamoto, Y., Aida, K., Kawauchi, H., 1994. Purification and characterization of gonadotropin I and II from pituitary glands of tuna (Thunnus obesus). Int. J. Pept. Protein Res. 43, 69-80.

Okubo, K., Amano, M., Yoshiura, Y., Suetake, H., Aida, K., 2000. A novel form of gonadotropin-releasing hormone in the medaka, Oryzias latipes. Biochem. Biophys. Res. Com- 
mun. 276, 298-303.

Olivares, A., Mendez, J. P., Cardenas, M., Oviedo, N., Palomino, M. A., Santos, I., PereraMarin, G., Gutiérrez-Sagal, R., Ulloa-Aguirre, A., 2009. Pituitary-testicular axis function, biological to immunological ratio and charge isoform distribution of pituitary $\mathrm{LH}$ in male rats with experimental diabetes. Gen. Comp. Endocrinol. 161, 304-312.

Pandolfi, M., Lo Nostro, F. L., Shimizu, A., Pozzi, A. G., Meijide, F. J., Vázquez, G. R., Maggese, M. C., 2006. Identification of immunoreactive FSH and LH cells in the cichlid fish Cichlasoma dimerus during the ontogeny and sexual differentiation. Anatomy and Embryology. 211, 355-365.

Pankhurst, N. W., 2008. Gonadal steroids: Functions and Patterns of Change. In: M. J. Rocha, A. Arukwe, B. G. Kapoor, (Eds.), Fish Reproduction. Science Publishers, Enfield, NH, USA, pp. 67-111.

Papadaki, M., Piferrer, F., Zanuy, S., Maingot, E., Divanach, P., Mylonas, C. C., 2005. Growth, sex differentiation and gonad and plasma levels of sex steroids in male- and femaledominant populations of Dicentrarchus labrax obtained through repeated size grading. J. Fish Biol. 66, 938-956.

Pickett, G. D., Pawson, M. G., 1994. Sea bass: biology, exploitation and conservation. Chapman \& Hall, London (UK).

Pierce, J. G., Parsons, T. F., 1981. Glycoprotein hormones: structure and function. Annu. Rev. Biochem. 50, 465-495.

Piferrer, F., Blázquez, M., Navarro, L., González, A., 2005. Genetic, endocrine, and environmental components of sex determination and differentiation in the European sea bass (Dicentrarchus labrax L.). Gen. Comp. Endocrinol. 142, 102-110.

Planas, J., Swanson, P., 2008. Physiological functions of gonadotropins in fish. In: M. J. Rocha, A. Arukwe, B. G. Kapoor, (Eds.), Fish Reproduction. Science Publishers, Enfield, NH, USA, pp. 37-66.

Planas, J. V., Athos, J., Goetz, F. W., Swanson, P., 2000. Regulation of ovarian steroidogenesis in vitro by follicle-stimulating hormone and luteinizing hormone during sexual maturation in salmonid fish. Biol. Reprod. 62, 1262-1269.

Planas, J. V., Swanson, P., 1995. Maturation-associated changes in the response of the salmon testis to the steroidogenic actions of gonadotropins (GTH I and GTH II) in vitro. Biol. Reprod. 52, 697-704.

Powell, J.F., Zohar, Y., Elizur, A., Park, M., Fischer, W.H., Craig, A.G., Rivier, J.E., Lovejoy, D.A., Sherwood, N.M., 1994. Three forms of gonadotropin-releasing hormone characterized from brains of one species. Proc. Natl. Acad. Sci. USA 91, 12081-12085.

Prat, F., Sumpter, J. P., Tyler, C. R., 1996. Validation of radioimmunoassays for two salmon gonadotropins (GTH I and GTH II) and their plasma concentrations throughout the reproductive cycle in male and female rainbow trout (Oncorhynchus mykiss). Biol. Reprod. 54, 1375-1382.

Prat, F., Zanuy, S., Carrillo, M., de Mones, A., Fostier, A., 1990. Seasonal changes in plasma levels of gonadal steroids of sea bass, Dicentrarchus labrax L. Gen. Comp. Endocrinol. 78, 361-373.

Pudney, J., 1995. Spermatogenesis in nonmammalian vertebrates. Microsc. Res. Tech. 32, 459-497.

Querat, B., Arai, Y., Henry, A., Akama, Y., Longhurst, T. J., Joss, J. M. P., 2004. Pituitary glycoprotein hormone beta subunits in the Australian lungfish and estimation of the 
relative evolution rate of these subunits within vertebrates. Biol. Reprod. 70, 356-363.

Querat, B., Sellouk, A., Salmon, C., 2000. Phylogenetic analysis of the vertebrate glycoprotein hormone family including new sequences of sturgeon (Acipenser baeri) beta subunits of the two gonadotropins and the thyroid-stimulating hormone. Biol. Reprod. 63, 222-228.

Rocha, A., 2008. Caracterización molecular de los receptores de gonadotrofinas de lubina (Dicentrarchus labrax). Universidad de Valencia. Tesis Doctoral.

Rocha, A., Gómez, A., Zanuy, S., Cerda-Reverter, J. M., Carrillo, M., 2007. Molecular characterization of two sea bass gonadotropin receptors: cDNA cloning, expression analysis, and functional activity. Mol. Cell. Endocrinol. 272, 63-76.

Rocha, A., Zanuy, S., Carrillo, M., Gómez, A., 2009. Seasonal changes in gonadal expression of gonadotropin receptors, steroidogenic acute regulatory protein and steroidogenic enzymes in the European sea bass. Gen. Comp. Endocrinol. 162, 265-275.

Rodríguez, L., Begtashi, I., Zanuy, S., Carrillo, M., 2005. Long-term exposure to continuous light inhibits precocity in European male sea bass (Dicentrarchus labrax, L.): hormonal aspects. Gen. Comp. Endocrinol. 140, 116-25.

Rodríguez, L., Carrillo, M., Sorbera, L. A., Zohar, Y., Zanuy, S., 2004. Effects of photoperiod on pituitary levels of three forms of $\mathrm{GnRH}$ and reproductive hormones in the male European sea bass (Dicentrarchus labrax, L.) during testicular differentiation and first testicular recrudescence. Gen. Comp. Endocrinol. 136, 37-48.

Rodríguez, L., Zanuy, S., Carrillo, M., 2001. Influence of daylength on the age at first maturity and somatic growth in male sea bass (Dicentrarchus labrax, L.). Aquaculture. 196, 159-175.

Rose, M. P., Gaines Das, R. E., Balen, A. H., 2000. Definition and measurement of follicle stimulating hormone. Endocr. Rev. 21, 5-22.

Rulli, S. B., Creus, S., Pellizzari, E., Cigorraga, S. B., Calandra, R. S., Campo, S., 1999. Androgen regulation of immunological and biological activities of pituitary folliclestimulating hormone isoforms in male rats. Neuroendocrinology. 70, 255-260.

Saga, T., Oota, Y., Nozaki, M., Swanson, P., 1993. Salmonid Pituitary Gonadotrophs. III. Chronological appearance of Gth-1 and other adenohypophyseal hormones in the pituitary of the developing rainbow-trout (Oncorhynchus mykiss irideus). Gen. Comp. Endocrinol. 92, 233-241.

Saillant, E., Fostier, A., Haffray, P., Menu, B., Laureau, S., Thimonier, J., Chatain, B., 2003. Effects of rearing density, size grading and parental factors on sex ratios of the sea bass (Dicentrarchus labrax L.) in intensive aquaculture. Aquaculture. 221, 183-206.

Sambroni, E., Le Gac, F., Breton, B., Lareyre, J. J., 2007. Functional specificity of the rainbow trout (Oncorhynchus mykiss) gonadotropin receptors as assayed in a mammalian cell line. J. Endocrinol. 195, 213-228.

Santos, E. M., Rand-Weaver, M., Tyler, C. R., 2001. Follicle-stimulating hormone and its $\alpha$ and $\beta$ subunits in rainbow trout (Oncorhynchus mykiss): purification, characterization, development of specific radioimmunoassays, and their seasonal plasma and pituitary concentrations in females. Biol. Reprod. 65, 288-294.

Salbert, G., Bailhache, T., Zohar, Y., Breton, B., Jego, P., 1990. A rapid and sensitive ELISA for rainbow trout maturational gonadotropin ( $t \mathrm{GtH}$ II): Validation on biological samples; in vivo and in vitro responses to GnRH. Gen. Comp. Endocrinol. 78, 110-122.

Schulz, R., Miura, T., 2002. Spermatogenesis and its endocrine regulation. Fish Physiol. 
Biochem. 26, 43-56.

Schulz, R. W., de Franca, L. R., Lareyre, J. J., Legac, F., Chiarini-Garcia, H., Nobrega, R. H., Miura, T., 2010. Spermatogenesis in fish. Gen. Comp. Endocrinol. 165, 390-411.

Sealfon, S. C., Weinstein, H., Millar, R. P., 1997. Molecular mechanisms of ligand interaction with the gonadotropin-releasing hormone receptor. Endocr. Rev. 18, 180-205.

Senthilkumaran, B., Yoshikuni, M., Nagahama, Y., 2004. A shift in steroidogenesis occurring in ovarian follicles prior to oocyte maturation. Mol. Cell. Endocrinol. 215, 11-18.

Sherwood, N., Eiden, L., Brownstein, M., Spiess, J., Rivier, J., Vale, W., 1983. Characterization of a teleost gonadotropin-releasing hormone. Proc. Natl. Acad. Sci. USA 80, 2794-2798.

Sherwood, N.M., Sower, S.A., Marshak, D.R., Fraser, B.A., Brownstein, M.J., 1986. Primary structure of gonadotropin-releasing hormone from lamprey brain. J. Biol. Chem. 261, 4812-4819.

Shimizu, A., Yamashita, M., 2002. Purification of mummichog (Fundulus heteroclitus) gonadotropins and their subunits, using an immunochemical assay with antisera raised against synthetic peptides. Gen. Comp. Endocrinol. 125, 79-91.

Silver, M. R., Kawauchi, H., Nozaki, M., Sower, S. A., 2004. Cloning and analysis of the lamprey GnRH-III cDNA from eight species of lamprey representing the three families of Petromyzoniformes. Gen. Comp. Endocrinol. 139, 85-94.

So, W. K., Kwok, H. F., Ge, W., 2005. Zebrafish gonadotropins and their receptors: II. Cloning and characterization of zebrafish follicle-stimulating hormone and luteinizing hormone subunits--their spatial-temporal expression patterns and receptor specificity. Biol. Reprod. 72, 1382-96.

Sohn, Y. C., Yoshiura, Y., Kobayashi, M., Aida, K., 1999. Seasonal changes in mRNA levels of gonadotropin and thyrotropin subunits in the goldfish, Carassius auratus. Gen. Comp. Endocrinol. 113, 436-444.

Sower, S.A., Chiang, Y.C., Lovas, S., Conlon, J.M., 1993. Primary structure and biological activity of a third gonadotropin-releasing hormone from lamprey brain. Endocrinology 132, 1125-1131.

Suwa, K., Yamashita, M., 2007. Regulatory mechanisms of oocyte maturation and ovulation. In: P. Babin, J. Cerda, E. Lubzens, (Eds.), The Fish Oocyte: From Basic Studies to Biotechnological Applications. Springer, Dordrecht, The Netherlands, pp. 323-347.

Suzuki, K., Kanamori, A., Nagahama, Y., Kawauchi, H., 1988d. Development of salmon GTH I and GTH II radioimmunoassays. Gen. Comp. Endocrinol. 71, 459-467.

Suzuki, K., Kawauchi, H., Nagahama, Y., 1988a. Isolation and characterization of two distinct gonadotropins from chum salmon pituitary glands. Gen. Comp. Endocrinol. 71, 292-301.

Suzuki, K., Kawauchi, H., Nagahama, Y., 1988b. Isolation and characterization of subunits from two distinct salmon gonadotropins. Gen. Comp. Endocrinol. 71, 302-306.

Suzuki, K., Nagahama, Y., Kawauchi, H., 1988c. Steroidogenic activities of two distinct salmon gonadotropins. Gen. Comp. Endocrinol. 71, 452-458.

Swanson, P., 1991. Salmon gonadotropins: reconciling old and new ideas. In: Scott A. P., Sumpter J. P., Kime D. E., Rolfe M. S. (Eds.), Reproductive Physiology of Fish, Sheffield: FishSymp, pp. 2-7.

Swanson, P., Bernard, M., Nozaki, M., Suzuki, K., Kawauchi, H., Dickhoff, W. W., 1989. Gonadotropin-I and Gonadotropin-II in Juvenile Coho Salmon. Fish Physiol. Biochem. 
7, 169-176.

Swanson, P., Dickey, J. T., Campbell, B., 2003. Biochemistry and physiology of fish gonadotropins. Fish Physiol. Biochem. 28, 53-59.

Swanson, P., Suzuki, K., Kawauchi, H., Dickhoff, W. W., 1991. Isolation and characterization of two coho salmon gonadotropins, GTH I and GTH II. Biol. Reprod. 44, 29-38.

Tanaka, H., Kagawa, H., Okuzawa, K., Hirose, K., 1993. Purification of gonadotropins (PmGTH-I and II) from red seabream (Pagrus major) and development of a homologous radioimmunoassay for PmGTH-II. Fish Physiol. Biochem. 10, 409-418.

Tano, M., Minegishi, T., Nakamura, K., Karino, S. and Ibuki, Y. (1995) Application of Chinese hamster ovary cells transfected with the recombinant human follicle-stimulating hormone (FSH) receptor for measurement of serum FSH. Fertil. Steril. 64, 1120-1124.

Taranger, G. L., Carrillo, M., Schulz, R. W., Fontaine, P., Zanuy, S., Felip, A., Weltzien, F. A., Dufour, S., Karlsen, O., Norberg, B., Andersson, E., Hansen, T., 2010. Control of puberty in farmed fish. Gen. Comp. Endocrinol. 165, 483-515.

Tilly, J. L., Aihara, T., Nishimori, K., Jia, X. C., Billig, H., Kowalski, K. I., Perlas, E. A., Hsueh, A. J., 1992. Expression of recombinant human follicle-stimulating hormone receptor: species-specific ligand binding, signal transduction, and identification of multiple ovarian messenger ribonucleic acid transcripts. Endocrinology. 131, 799-806.

Tyler, C. R., Pottinger, T. C., Coward, K., Prat, F., Beresford, N., Maddix, S., 1997. Salmonid follicle-stimulating hormone (GtH I) mediates vitellogenic development of oocytes in the rainbow trout, Oncorhynchus mykiss. Biol. Reprod. 57, 1238-1244.

Tyler, C. R., Sumpter, J. P., Kawauchi, H., Swanson, P., 1991. Involvement of Gonadotropin in the Uptake of Vitellogenin into Vitellogenic Oocytes of the Rainbow Trout, Oncorhynchus mykiss. Gen. Comp. Endocrinol. 84, 291-299.

Ulloa-Aguirre, A., Maldonado, A., Damian-Matsumura, P., Timossi, C., 2001. Endocrine regulation of gonadotropin glycosylation. Arch. Med. Res. 32, 520-532.

Ulloa-Aguirre, A., Timossi, C., Barrios-de-Tomasi, J., Maldonado, A., Nayudu, P., 2003. Impact of carbohydrate heterogeneity in function of follicle-stimulating hormone: Studies derived from in vitro and in vivo models. Biol. Reprod. 69, 379-389.

Ulloa-Aguirre, A., Timossi, C., Damián-Matsumura, P., Dias, J., 1999. Role of glycosylation in function of follicle-stimulating hormone. Endocrine, 11, 205-215.

Ulloa-Aguirre, A., Uribe, A., Zariñán, T., Bustos-Jaimes, I., Pérez-Solis, M. A., Dias, J. A., 2007. Role of the intracellular domains of the human FSH receptor in G (alpha S) protein coupling and receptor expression. Mol. Cell. Endocrinol. 260, 153-162.

Van de Wiel, D. F., van Rijn, P. A., Meloen, R. H., Moormann, R. J., 1998. High-level expression of biologically active recombinant bovine follicle stimulating hormone in a baculovirus system. J. Mol. Endocrinol. 20, 83-98.

Van der Kraak, G., Suzuki, K., Peter, R. E., Itoh, H., Kawauchi, H., 1992. Properties of common carp gonadotropin I and gonadotropin II. Gen. Comp. Endocrinol. 85, 217-229.

Vassart, G., Pardo, L., Costagliola, S., 2004. A molecular dissection of the glycoprotein hormone receptors. Trends Biochem. Sci. 29, 119-126.

Vischer, H. F., Bogerd, J., 2003. Cloning and functional characterization of a gonadal luteinizing hormone receptor complementary DNA from the African catfish (Clarias gariepinus). Biol. Reprod. 68, 262-271.

Vischer, H. F., Granneman, J. C., Linskens, M. H., Schulz, R. W., Bogerd, J., 2003. Both recombinant African catfish $\mathrm{LH}$ and FSH are able to activate the African catfish FSH 
receptor. J. Mol. Endocrinol. 31, 133-40.

Vizziano, D., Fostier, A., Loir, M., Le Gac, F., 2008. Testis Development, its Hormonal Regulation and Spermiation Induction in Teleost Fish. In: S. M. Hadi Alavi, J. J. Cosson, K. Coward, G. Rafiee, (Eds.), Fish Spermatology. Alpha Science, Oxford, UK, pp. 103-139.

Wallace, R. A., Selman, K., 1981. Cellular and Dynamic Aspects of Oocyte Growth in Teleosts. American Zoologist. 21, 325-343.

Weltzien, F. A., Andersson, E., Andersen, O., Shalchian-Tabrizi, K., Norberg, B., 2004. The brain-pituitary-gonad axis in male teleosts, with special emphasis on flatfish (Pleuronectiformes). Comp. Biochem. Physiol. A Mol. Integr. Physiol. 137, 447-477.

Weltzien, F. A., Norberg, B., Swanson, P., 2003. Isolation and characterization of FSH and LH from pituitary glands of Atlantic halibut (Hippoglossus hippoglossus L.). Gen. Comp. Endocrinol. 131, 97-105.

Yamaguchi, T., Yamaguchi, S., Hirai, T., Kitano, T., 2007. Follicle-stimulating hormone signaling and Foxl 2 are involved in transcriptional regulation of aromatase gene during gonadal sex differentiation in Japanese flounder, Paralichthys olivaceus. Biochem. Biophys. Res. Commun. 359, 935-940.

Yaron, Z., Levavi-Sivan, B., 2006. Fish Reproduction. In: D. H. Evans, J. B. Claiborne, (Eds.), The Physiology of Fishes. CRC Press, New York, pp. 343-386.

Yoo, M.S., Kang, H.M., Choi, H.S., Kim, J.W., Troskie, B.E., Millar, R.P., Kwon, H.B., 2000. Molecular cloning, distribution and pharmacological characterization of a novel gonadotropin-releasing hormone ([Trp8] GnRH) in frog brain. Mol. Cell. Endocrinol. 164, 197-204.

Yu, X. B., Lin, S. W., Kobayashi, M., Ge, W., 2010. Expression of recombinant zebrafish follicle-stimulating hormone (FSH) in methylotropic yeast Pichia pastoris. Fish Physiol. Biochem. 36, 273-281.

Zambrano, E., Barrios-de-Tomasi, J., Cardenas, M., Ulloa-Aguirre, A., 1996. Studies on the relative in-vitro biological potency of the naturally-occurring isoforms of intrapituitary follicle stimulating hormone. Mol. Hum. Reprod. 2, 563-571.

Zanuy, S., Carrillo, M., Rocha, A., Molés, G., 2009. Regulación y control hormonal del proceso reproductor de los teleósteos. In: J. E. de los Monteros, M. Carrillo, (Eds.), La reproducción de los peces: aspectos básicos y sus aplicaciones en acuicultura. Publicaciones Cientificas y Tecnológicas de la Fundacion Observatorio Español de Acuicultura, Madrid, pp. 99-172.

Zariñán, T., Olivares, A., Söderlund, D., Méndez, J.P., Ulloa-Aguirre, A., 2001. Changes in the biological:immunological ratio of basal and GnRH-releasable FSH during the follicular, pre-ovulatory and luteal phases of the human menstrual cycle. Hum. Reprod. $16,1611-1618$.

Zhang, S. B., Dattatreyamurty, B., Reichert, L. E., 1991. Differential Roles of High and Low Affinity Guanosine 5'-Triphosphate Binding-Sites in the Regulation of Follicle-Stimulating-Hormone Binding to Receptor and Signal Transduction in Bovine Calf Testis Membranes. Endocrinology. 128, 295-302.

Zmora, N., Kazeto, Y., Kumar, R. S., Schulz, R. W., Trant, J. M., 2007. Production of recombinant channel catfish (Ictalurus punctatus) FSH and LH in S2 Drosophila cell line and an indication of their different actions. J. Endocrinol. 194, 407-16.

Zmora, N., Kumar, S., Kazeto, Y., Trant, J.M., 2003. Production of channel catfish (Ictalurus punctatus) recombinant gonadotropins using the S2 Drosophila cell line system. Fish 
Physiol. Biochem. 28, 475-477.

Zohar, Y., Breton, B., Sambroni, E., Fostier, A., Tosky, M., Pagelson, G., Leibovitz, D., 1990. Development of a homologous radioimmunoassay for a gonadotropin of the gilthead seabream, Sparus aurata. Aquaculture. 88, 189-204.

Zohar, Y., Elizur, A., Sherwood, N. M., Powell, J. F., Rivier, J. E., Zmora, N., 1995. Gonadotropin-releasing activities of the three native forms of gonadotropin-releasing hormone present in the brain of gilthead seabream, Sparus aurata. Gen. Comp. Endocrinol. 97, 289-299.

Zohar, Y., Muñoz-Cueto, J. A., Elizur, A., Kah, O., 2010. Neuroendocrinology of reproduction in teleost fish. Gen. Comp. Endocrinol. 165, 438-455. 



\section{RESUMENES}





\section{Resumen en castellano}

La reproducción es un proceso biológico de gran interés en acuicultura debido a que su control es un factor limitante para la producción de peces en cautividad. El éxito reproductivo de una especie en régimen de cultivo depende de un profundo conocimiento de los procesos básicos que regulan la puesta en funcionamiento del ciclo reproductor y su alternancia. En peces, como en otros vertebrados, la reproducción esta regulada por una cascada hormonal que ocurre a lo largo de una red neuro-endocrina compuesta por el cerebro, la hipófisis y las gónadas (eje CHG). Entre las principales hormonas implicadas destacan las hormonas liberadoras de gonadotrofinas (GnRHs), las gonadotrofinas (GTHs) y los esteroides sexuales. En este marco, las GTHs - hormona folículo estimulante (FSH) y hormona luteinizante (LH) - tienen un papel central y el conocimiento de su estructura y modo de acción es esencial para comprender y controlar el ciclo reproductor. Los estudios realizados en los últimos años han permitido dilucidar algunos aspectos bioquímicos y fisiológicos de estas hormonas en peces. Sin embargo, la dualidad funcional de las GTHs no esta totalmente clara en muchas especies de teleósteos debido a la falta de herramientas apropiadas para su estudio, principalmente de ensayos para determinar sus niveles en momentos críticos del ciclo reproductor.

Para abordar este problema en la lubina (Dicentrarchus labrax), un Perciforme marino de gran interés en acuicultura, se ha purificado la FSH nativa y se han producido diferentes GTHs recombinantes. Esto ha permitido caracterizarlas bioquímica y funcionalmente y desarrollar ensayos específicos (biológicos e inmunológicos) para medir FSH, los cuales representan una valiosa herramienta para el estudio de la endocrinología reproductiva de esta especie. Además, se han puesto a punto herramientas moleculares para estudiar los perfiles de expresión génica de las GnRHs, GnRHR y GTHs. Todas estas herramientas, junto con otras disponibles en nuestro laboratorio han permitido investigar la función de las GTHs durante la diferenciación sexual y la gametogénesis de la lubina.

Los resultados obtenidos muestran que ambas GTHs activan específicamente sus respectivos receptores, sin mostrar actividad cruzada en un amplio rango de concentraciones, y son capaces de inducir la síntesis de esteroides sexuales en cultivos in vitro. Los perfiles hormonales y de ex- 
presión génica obtenidos durante la diferenciación sexual sugieren un papel clave para la FSH, cuya síntesis y potencia presenta cierto dimorfismo sexual y parece estar regulada principalmente por sbGnRH. Además, los análisis inmunohistoquímicos en hipófisis muestran que la FSH y la LH se sintetizan en células de la adenohipófisis diferentes. Por ultimo, los perfiles hormonales obtenidos en lubinas prepúberes y adultas sugieren que la FSH esta implicada en la iniciación y mantenimiento de la espermatogénesis y la vitelogénesis. Por el contrario, la LH parece estar involucrada en las fases finales de la gametogénesis como la espermiogénesis, espermiación, maduración y ovulación. 


\section{Resum en valencià}

La reproducció és un procés biològic de gran interès en aqüicultura ja que, el seu control és un factor limitant per a la producció de peixos en captivitat. L'èxit reproductiu d'una espècie en règim de cultiu depèn d'un profund coneixement dels processos bàsics que regulen la posada en funcionament del cicle reproductor i la seva alternança. En peixos, com en altres vertebrats, la reproducció està regulada per una cascada hormonal que passa al llarg d'una xarxa neuro-endocrina composta pel cervell, la hipòfisi i les gònades (eix CHG). Entre les principals hormones implicades destaquen les hormones alliberadores de gonadotrofines (GnRHs), les gonadotrofines (GTHs) i els esteroides sexuals. En aquest marc, les GTHs - hormona follicle estimulant (FSH) i hormona luteïnitzant (LH) - tenen un paper central i el coneixement de la seva estructura i manera d'acció és essencial per a comprendre i controlar el cicle reproductor. Els estudis realitzats en els últims anys han permès dilucidar alguns aspectes bioquímics i fisiològics d'aquestes hormones en peixos. No obstant això, la dualitat funcional de les GTHs no està totalment clara en moltes espècies de teleostis a causa de la falta d'eines apropiades per al seu estudi, principalment d'assaigs per determinar els seus nivells en moments crítics del cicle reproductor.

Per abordar aquest problema en el llobarro (Dicentrarchus labrax), un Perciforme marí de gran interès en aqüicultura, s'ha purificat la FSH nativa i s'han produït diferents GTHs recombinants. Això ha permès caracteritzar bioquímica i funcionalment i desenvolupar assaigs específics (biològics $\mathrm{i}$ immunològics) per mesurar FSH, els quals representen una valuosa eina per al'estudi de l'endocrinologia reproductiva d'aquesta espècie. A més, s'han posat a punt eines moleculars per estudiar els perfils d'expressió gènica de les GnRHs, GnRHR i GTHs. Totes aquestes eines, juntament amb altres disponibles al nostre laboratori han permès investigar la funció de les GTHs durant la diferenciació sexual i la gametogènesi del llobarro.

Els resultats obtinguts mostren que les dues GTHs activen específicament els seus respectius receptors, sense mostrar activitat creuada en un ampli rang de concentracions, i són capaços d'induir la síntesi d'esteroides sexuals en cultius in vitro. Els perfils hormonals i d'expressió gènica obtinguts durant la diferenciació sexual suggereixen un paper clau per a la FSH, la síntesi i potència de la qual presenta cert dimorfisme sexual i sembla 
estar regulada principalment per sbGnRH. A més, els anàlisis immunohistoquímics en hipòfisi mostren que la FSH i la LH es sintetitzen en cèlllules de la adenohipòfisi diferents. Finalment, els perfils hormonals obtinguts en llobarros prepúbers i adults suggereixen que la FSH esta implicada en la iniciació i manteniment de l'espermatogènesi i la vitelogénesis. Per contra, la LH sembla estar involucrada en les fases finals de la gametogènesi com l'espermiogènesi, espermiació, maduració i ovulació. 


\section{English summary}

Reproduction is a biological process of great interest for aquaculture since its control is a limiting factor for production of fish in captivity. The reproductive success of a species under confinement depends on a deep understanding of the basic processes that govern the initiation of puberty and maintenance of reproductive cyclicity. In fish, as in other vertebrates, reproduction is regulated by a hormonal cascade that occurs over a neuroendocrine network composed of the brain, the pituitary and the gonads (BPG axis). The main hormones involved include the gonadotropin-releasing hormone (GnRHs), gonadotropins (GTHs) and sex steroids. In this context, GTHs - follicle stimulating hormone (FSH) and luteinizing hormone (LH) - have a central role. Knowledge of its structure and mode of action is essential to understand and control the reproductive cycle. Studies in recent years have allowed elucidating biochemical and physiological aspects of these hormones in fish. However, the functional duality of GTHs is not entirely clear in many teleost species due to the lack of appropriate tools for their study, primarily assays to determine their levels at critical times of the reproductive cycle.

To address this problem in the sea bass (Dicentrarchus labrax), a marine Perciform of great interest for aquaculture, native FSH has been purified and different recombinant GTHs have been produced. This has allowed to characterize, biochemically and functionally, the sea bass GTHs and to develop specific assays (biological and immunological) to measure FSH, which represents a valuable tool for studying the reproductive endocrinology of this species. In addition, molecular tools have also been developed to study gene expression profiles of GnRHs, GnRHR and GTHs. These tools, along with others already available in our laboratory, have allowed investigating the role of GTHs during sexual differentiation and gametogenesis in the sea bass.

The results show that both GTHs specifically activate their respective receptors, showing no cross-reactivity in a wide range of concentrations, and that are able to induce the synthesis of sex steroids in vitro. During sexual differentiation, hormonal profiles and gene expression levels suggest a key role for FSH. Furthermore, the synthesis and biopotency of this hormone presents a sexual dimorphism and appears to be regulated primarily by 
sbGnRH. In addition, immunohistochemical analysis indicates that in the pituitary, FSH and LH are synthesized by different adenohypophysis cells. Finally, hormonal profiles obtained from prepubertal and adult sea bass suggest that FSH is involved in the initiation and maintenance of spermatogenesis and vitellogenesis. On the contrary, the LH appears to be involved in the final stages of gametogenesis such as spermiogenesis, spermiation, maturation and ovulation. 
